TESIS DE DOCTORADO

Facultad de Ciencias Naturales y Museo

Universidad Nacional de La Plata

\title{
LA RE-PRESENTACIÓN DE LA ETNOGRAFÍA EN MUSEOS
}

\author{
Tesista, Lic. María Marta Reca \\ Director, Dr. Héctor B. Lahitte \\ Co-director, Lic. Juan Magariños de Morentín
}

La Plata- abril de 2010 


\section{LA RE-PRESENTACIÓN DE LA ETNOGRAFÍA EN MUSEOS}

TESIS DE DOCTORADO

Facultad de Ciencias Naturales y Museo

Universidad Nacional de La Plata

Tesista, Lic. María Marta Reca

Director, Dr. Héctor B. Lahitte

Co-director, Lic. Juan Magariños de Morentín

La Plata- abril de 2010 
A Quique
y a nuestros hijos
Lucio, Guillermina y Amparo 


\section{Agradecimientos:}

Agradezco a mi Director, el Dr. Héctor Lahitte de quien aprendí, durante tantos años compartidos, que la antropología es una reflexión constante acerca de los otros pero siempre, desde quienes somos, como clave ineludible de nuestro existir.

A la memoria del Prof. Juan Magarinos de Morentín, co-director de esta tesis, con quien construí la arquitectura lógica desde donde otorgamos sentido a esa reflexión, como un homenaje a nuestra facultad semiótica.

A la Dra. Silvia Ametrano, Directora del Museo de La Plata, de cuyos valores se nutre la transformación trascendente de esta institución, y que tengo el privilegio de acompañar desde hace diez años.

Al equipo de la Unidad de Conservación y Exhibición, Rolando Vázquez, Alejandra Inacio, Miryam Hara, Silvia Marcianessi, Silvia de la Cruz, Agustina Martínez Azpelicueta, Samanta Cortés, Carlos Brianesse y a la memoria de Federico Carden, hacedores de la sala etnografía "Espejos Culturales". Seguramente ellos no imaginan la importancia y riqueza de nuestros intercambios cotidianos, los que, sin duda, se filtran en esta tesis.

A Claudia Tambussi, Analía Martino, Marina Sardi, María Eugenia Martins, Rosana Menna, Pablo Rodriguez y Marta Maffia por sus comentarios alentadores y afectuoso acompañamiento, traducido en múltiples charlas e intercambios.

A la Unidad de Medios Audiovisuales del Museo de La Plata, por la realización desinteresada del registro videográfico de la sala "Espejos Culturales".

A mis hermanos, Pablo, Damián, María Teresa y Martín, con quienes comparto los códigos familiares heredados de la racionalidad de Ricardo y la sensibilidad de Estela, siempre presentes.

Con especial gratitud dedico esta tesis a Quique y a nuestros hijos, Lucio, Guillermina y Amparo. Ellos me acompañaron con incondicionalidad y son mi fuente de inspiración más valiosa. 


\section{INDICE}

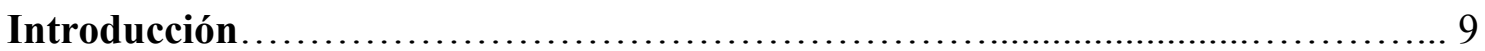

\section{Capítulo I: ANTROPOLOGÍA Y MUSEOS}

I.1. El origen de los museos: antecedentes de los museos de antropología ..................................................... 16

I.2. La realidad como objeto y el objeto real como evidencia ...................... 19

I.3. La antropología como disciplina y la representación del Otro cultural en las salas de museo. .......................................... 22

I.4. La cultura exótica: el evolucionismo y el particularismo

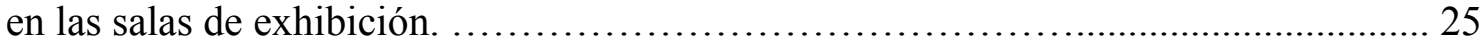

I.5. El Museo de La Plata. ................................................... 32

\section{Capítulo II: EL PROBLEMA DE LA RE-PRESENTACIÓN}

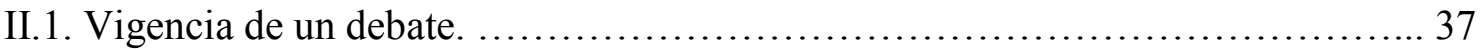

II.2. La sospecha de lo que viene dado. ...................................... 40

II.3. La vuelta a los museos. .................................................. 43

II.4. Elementos para un análisis crítico. ..................................... 47

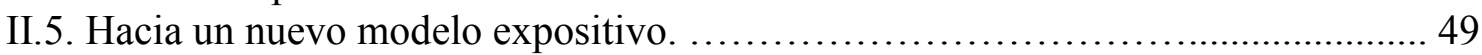

II.6. De cuerpo presente. ................................................. 54

\section{Capítulo III: ESPACIOS, OBJETOS E INTÉRPRETES}

III.1.La mirada semiótica y los contextos de significación. .................................... 58

III.2. El acto de adjudicación de sentido es siempre

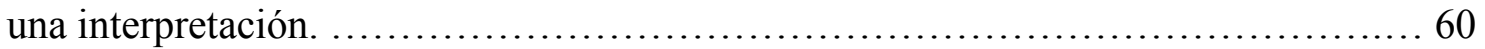

III.3. El átomo de sentido desde Peirce. ........................................ 65

III.4. El contexto de recolección: el objeto de colección y su condición de etnográfico. .............................................. 68

III.5. El contexto de re-presentación: la sala de exhibición como espacio intersemiótico. ................................................. 73

III.6. El contexto de apropiación: los discursos de los visitantes. ................. 77

III.7. Inter-relaciones y re-presentación. ...................................... 79

\section{Capítulo IV: ESPEJOS CULTURALES: LA SALA} ETNOGRAFÍA DEL MUSEO DE LA PLATA

IV.1. Espejos culturales: alcances de la innovación. ............................ 82

IV.2. Los niveles relacionales desde donde se articula la exhibición. ............... 87

IV.3. Acerca de los conceptos rectores. .................................... 90

IV.4. Los recursos expositivos. ......................................... 93

IV.5. Relaciones de producción. .......................................... 98

IV.6. Anexos: -1. Planos. ......................................................... 101

-2. Fotos de la sala Etnografía ................................ 105

-3. Ejemplos de textos según jerarquización. ..................... 114 


\section{Capítulo V: LOS VISITANTES Y EL CONTEXTO DE APROPIACIÓN}

V.1. Antecedentes de los estudios de visitantes a museos. ......................... 121

V.2. Cognición, habitus y capital cultural. ..................................... 126

V.3. La aproximación cualitativa y los estudios de recepción. ....................... 134

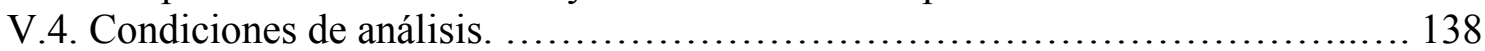

V.5. La semiótica y el análisis de discurso. .................................... 140

V.6. Las operaciones analíticas. ......................................... 146

\section{Capítulo VI: DEFINICIONES CONTEXTUALES Y MUNDOS SEMIÓTICOS POSIBLES}

VI.1. Los procedimientos analíticos. ....................................... 156

VI.2. Organización de la enunciación: variables, nodos y redes. ................... 158

VI.3. Análisis de las categorías de primer orden:

generalidades, textos, objetos. ............................................. 160

VI.4. Análisis de las categorías de segundo orden:

sector máscaras, sector escenario, sector video/mapas. ........................ 164

VI.5. Análisis de las categorías de tercer orden:
tiempo, identidad y autoreferencia. ........................................... 169

VI.6. Resultados. ..................................................... 174

VI.7. Anexos: - 1. Composición de la muestra. ................................. 182

- 2. Definiciones contextuales: ejemplos según apartados y nodos. ........................... 187

- 3. Matrices de relaciones entre nodos y subnodos. .................. 211

Capítulo VII: CONSIDERACIONES FINALES............................. 224

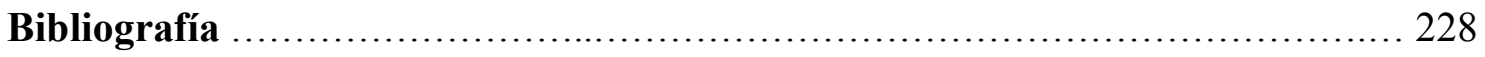




\section{RESUMEN}

La re-presentación de la identidad de las culturas etnográficas en las salas de exhibición de un museo es siempre un tema problemático. En ella subyace el conjunto de supuestos, no siempre explícitos, que la teoría antropología plantea en el estudio y construcción de la otredad. La presente tesis tiene por objeto analizar la "puesta en escena" de los materiales etnográficos en las salas de un museo y su relación con las formas de apropiación del conocimiento representado por parte de los visitantes. Toma como referente de análisis la nueva sala de exhibición permanente del Museo de La Plata perteneciente a la Facultad de Ciencias Naturales y Museo de la Universidad Nacional de La Plata. Recientemente inaugurada bajo el nombre de Espejos Culturales se describen los niveles de intertextualidad que se yuxtaponen en la labor expositiva, las intenciones de los curadores y las ideas rectoras que orientaron su elaboración. Con el objeto de evaluar su eficacia comunicativa se asume el análisis de los discursos producidos por los visitantes/intérpretes luego de la visita, a partir de un abordaje metodológico de carácter cualitativo, para recuperar los "mundos semióticos posibles" que organizan la visita como experiencia situada. La sala es concebida como un discurso con estrategias particulares y el visitante como un sujeto/intérprete que activa su capital cultural, en el marco de un aprendizaje significativo.

Desde un enfoque semiótico y comunicacional, se reconocen tres contextos de significación en los cuales los objetos de colección etnográficos son susceptibles de interpretación, denominados respectivamente de recolección, de re-presentación y de apropiación, demostrando así el carácter mediador de la sala de exhibición.

Durante el recorrido de la tesis se pretende reflejar la complejidad de todas las instancias de producción, su carácter transdisciplinar, y aportar a una mirada reflexiva y actualizada de la institución museo. Así, las reflexiones finales son, a su vez una apertura hacia nuevas vías de indagación acerca del rol de los museos en la sociedad, un aporte al diseño de un política institucional y se propone prefigurar cuestiones vinculadas a una ética de la representación que hoy incorpora como actores protagonistas a los descendientes de las culturas históricamente representadas en las salas de etnografía. 


\section{ABSTRACT}

The re-presentation of the identity of ethnographical cultures in museum exhibition halls is always a problematic issue, given the underlying set of assumptions, not always explicit, put forward by anthropological theory in the study and construction of otherness. The goal of this thesis is to analyze the "mise-en-scène" of ethnographicalmaterials in the halls of a museum and its relationship with the modes of appropriation of the represented knowledge on the part of the visitors. The reference for this analysis is the new permanent exhibition hall in the Museo de La Plata, an institution belonging to the Facultad de Ciencias Naturales y Museo of Universidad Nacional de la Plata. For this recently inaugurated hall, named "Cultural Mirrors", this work describes the levels of intertextuality juxtaposed in the work involved in this exposition, the curators' intentions and the guiding ideas that oriented its making. With the purpose of evaluating its communicative efficiency, an analysis of the discourses produced by visitors/interpreters after the visit was undertaken, through a qualitative methodological approach, in order to recover the "possible semiotic worlds" that organize the visit as a situated experience. The hall is envisioned as a discourse with particular strategies and the visitor as a subject/interpreter who activates his or her cultural capital within the framework of significant learning.

From a semiotic and communicational viewpoint, three contexts of significance, in hich objects from an ethnographical collection are susceptible of interpretation, are recognized: collection, re-presentation and appropriation, thus demonstrating the mediating nature of the exhibition hall.

The thesis endeavors to reflect the complexity of all stages of production, the transdisciplinar nature of the latter, and contribute an insightful and updated look on the museum as institution. Thus, the final considerations also represent an opening to new ways of examining the role of museums in society, a contribution to the design of an institutional policy, and a proposal for the prefiguration of issues related to an ethic of representation that today incorporates, as protagonists, the descendants of those cultures historically represented in ethnography halls. 


\section{LA RE-PRESENTACIÓN DE LA ETNOGRAFIA EN MUSEOS}

\section{Introducción:}

En las últimas décadas, los cuestionamientos acerca del modo en que los antropólogos construyen y re-presentan el conocimiento de otras culturas, junto a las nuevas tendencias de las exhibiciones, vuelve necesario revisar las relaciones entre ciencia y museos como divulgadores y herramientas de cambio social y, en particular, la etnografía como matriz conceptual que fundamenta y mediatiza la presentación de "otras culturas". La nueva etnografía y la implementación de metodologías tendientes a la comprensión de la "visión del nativo", las perspectivas interpretativas en la relación informante-antropólogo, las tendencias posmodernas y su cuestionamiento a la "autenticidad" de los resultados en la producción del conocimiento, la reflexión ante un mundo globalizado acompañado de lo efímero, así como la crisis del pensamiento moderno junto a la pérdida de los grandes relatos, son algunas de las cuestiones a tratar en el marco de un paradigma crítico que emerge de la mano del resurgimiento de las identidades locales, los estudios de memoria, la conciencia de lo complejo, el valor de las metodologías cualitativas, el paso de la certeza a la ambigüedad creativa.

El punto de partida del análisis propuesto en esta tesis es la reflexión en torno a las dificultades teóricas e ideológicas que conlleva asumir la re-presentación de otras culturas. A su vez, la multiplicidad de versiones e interpretaciones de las que puede ser motivo un mismo objeto, en el contexto de una exhibición de museo.

Como expresa Bárbara Kirshenblatt-Gimblegtt (1991) las exhibiciones, son muestras de los artefactos de nuestras disciplinas, por esta razón son también muestras de aquellos que las hacen, no importa cuál sea el sujeto ostensible. En consecuencia, lo primero a realizar es examinar críticamente las convenciones que guían a la muestra etnográfica, para explicar cómo las exhibiciones constituyen sujetos y cuáles son las implicancias para los que ven y para los que son vistos.

La presente tesis tiene por objeto dar a conocer los procedimientos teóricometodológicos y los niveles de discurso que se generan en las salas de un museo, en relación al patrimonio etnográfico y las formas de apropiación por parte de los visitantes en el marco de una situación comunicativa concreta.

La construcción de mensajes y las instancias de representación del conocimiento 
antropológico, otorga al objeto su valor de signo a través de un proceso analítico de contextualización, desde que la colección ingresa al museo hasta su exhibición. Esta trayectoria trae aparejada la reflexión acerca de los modos de re-presentación de "otras identidades", donde la "vitrina" es concebida como un nuevo contexto de resignificación.

Por otro lado, la elaboración del guión conceptual de una exhibición supone la adopción de un paradigma que exprese la misión de una sala y las ideas rectoras que orientan, a posteriori cada una de las elecciones, incluso aquellas más minúsculas y en apariencia insignificantes.

Desde una perspectiva relacional y constructivista, que impregna tanto el punto de vista del curador, la consideración del visitante y el sistema de interrelaciones propuestos a través de la exhibición, la construcción de sentido y su concreción se ubica en el marco de un proceso mucho más complejo del que habitualmente puede imaginarse una vez finalizada la exposición.

Adoptar un marco teórico constructivista y relacional implica, en principio, dar cuenta de la génesis del conocimiento, es decir, explicitar los criterios teóricometodológicos que fundamentan la trayectoria analítica. Desde un punto de vista epistemológico, el constructivismo pretende superar la dicotomía empirismo/racionalismo, para instalar el centro de atención en los procedimientos de construcción del objeto. A su vez, implica también reconocer una génesis social en los esquemas de percepción, de pensamiento y acción de modo que el sujeto/intérprete se encuentra inmerso en el proceso de producción de sentido (Bourdieu, 2008).

Tomando como referente de análisis la sala de exhibición permanente de etnografía del Museo de La Plata, recientemente renovada e inaugurada en marzo de 2007 con el nombre de "Espejos Culturales", se busca poner en relación dos dominios de análisis que presentan particularidades, articulaciones y elementos propios. Ambos son analizados desde una perspectiva semiótica, concebidos en su textualidad y en su dimensión comunicativa. La tarea consiste en la problematización de ambos dominios, una vez expuesta su validez como corpus de análisis.

El primero se refiere a la "puesta en escena" de los materiales etnográficos, la conexión (configuración) real y perceptible de un espacio bien delimitado en cuyo interior se articulan objetos, ideas, imágenes, secuencias en las que está anclado el 
conocimiento de "los otros". El segundo refiere al análisis de los "sujetos observadores", "perceptores" e "interpretantes", cuya configuración se materializa en el discurso producido por los visitantes luego de la visita a la exhibición.

Ambos dominios están enmarcados en una perspectiva que, en primer lugar abandona la idea de que dichos corpus constituyen una totalidad, proponiendo una delimitación teórico-metodológica pertinente para el análisis. En segundo lugar, ambos dominios admiten múltiples miradas/versiones, cuestionando así la perspectiva determinista y biunívoca en la construcción de sentido. Constituyen un abanico complejo de alternativas, posibilidades e incertidumbres de tal manera que los resultados no serán nunca un conocimiento acabado, equiparable a un modelo verdadero.

Entre ellos se establece una relación dialógica, y sus "condiciones de existencia" se encuentran condicionadas mutuamente, de tal manera que el modelo emergente predica sobre las relaciones entre ellos. Es allí donde la exhibición se conecta con los visitantes para configurar aquello que históricamente ha funcionado como un elemento definitorio de la institución museo y que, modelado por las ideas rectoras de las distintas épocas, delimita un campo discursivo particular.

El interés de tomar como referente de análisis de esta tesis la sala etnografía del Museo de La Plata radica en las reflexiones teóricas que moviliza, al concebirla como uno de los ámbitos de re-presentación del conocimiento antropológico, entendido, éste último, en su sentido más amplio como las formas de construcción del "otro" y del sí mismo, involucrando, en el primer dominio, al dato etnográfico $\mathrm{y}$, en el segundo, al imaginario social desde donde se configuran los "Espejos culturales".

Asimismo, en mi condición de coordinadora de la Unidad de Conservación y Exhibición de dicho museo, he sido protagonista, altamente involucrada en todas las instancias de su gestación y producción. De dicha experiencia proviene el conocimiento de los criterios que fueron debatidos y finalmente guiaron la elaboración y desarrollo del proyecto de remodelación.

Actualmente las colecciones etnográficas y su puesta en valor en las salas de exhibición, son motivo de una fuerte revisión, fundamentalmente vinculada a las formas y posibilidades de representación de otras culturas. ¿Cómo se conecta el objeto con su contexto de origen? ¿Es posible recuperar sus significados y traducirlos en el interior de 
la vitrina? ¿Qué papel cumple la antropología como disciplina? ¿Bajo qué intenciones, principios y paradigmas se construye el espacio de significación? Estas son algunas de las preguntas que organizan la comprensión de esta problemática.

A su vez, desde el lugar del observador/visitante los interrogantes giran en torno a preguntas tales como: ¿qué sujeto configura el visitante a partir de la propuesta expositiva? ¿Qué procesos cognitivos pone en juego en la situación comunicativa propuesta en la sala? ¿Cuáles son los posibles mundos semióticos en los que el objeto signo adopta un valor? Y, por último ¿Cómo es posible evaluar la "eficacia comunicativa" de la sala de exhibición? ¿De qué modo se ponen en contacto ambos dominios?

Llamaremos al primer dominio el de la re-presentación, y al segundo dominio, el de la apropiación del conocimiento representado. Estos se configuran a partir de la delimitación de tres contextos relacionales, conectados entre sí. El primero se refiere al conocimiento antropológico como campo disciplinar, fundamento de la representación, sus derivaciones y transformaciones. Alude a la construcción del conocimiento etnográfico y sus consecuencias en la calificación de un objeto de colección. El segundo contexto, hace referencia a las salas de exhibición y su conceptualización desde distintos modelos museológicos. Incorpora el análisis de los recursos museográficos y su condición de espacio tridimensional para la construcción de sentido. El tercer contexto está dado por los discursos producidos por el público a partir de la visita y su análisis diferencial para dar cuenta de los mundos semióticos posibles. En cada uno de ellos los objetos etnográficos adoptan significados diferenciales e involucran distintos intérpretes.

El primer dominio, de la re-presentación, es el resultado de las relaciones entre el conocimiento antropológico y su materialización en la sala de exhibición y, a partir del cual adquiere un contenido específico. El segundo dominio, el de la apropiación, refiere a las relaciones entre la sala como espacio comunicativo y los visitantes como intérpretes de dicho ámbito. 
El siguiente esquema pone en relación ambos dominios:

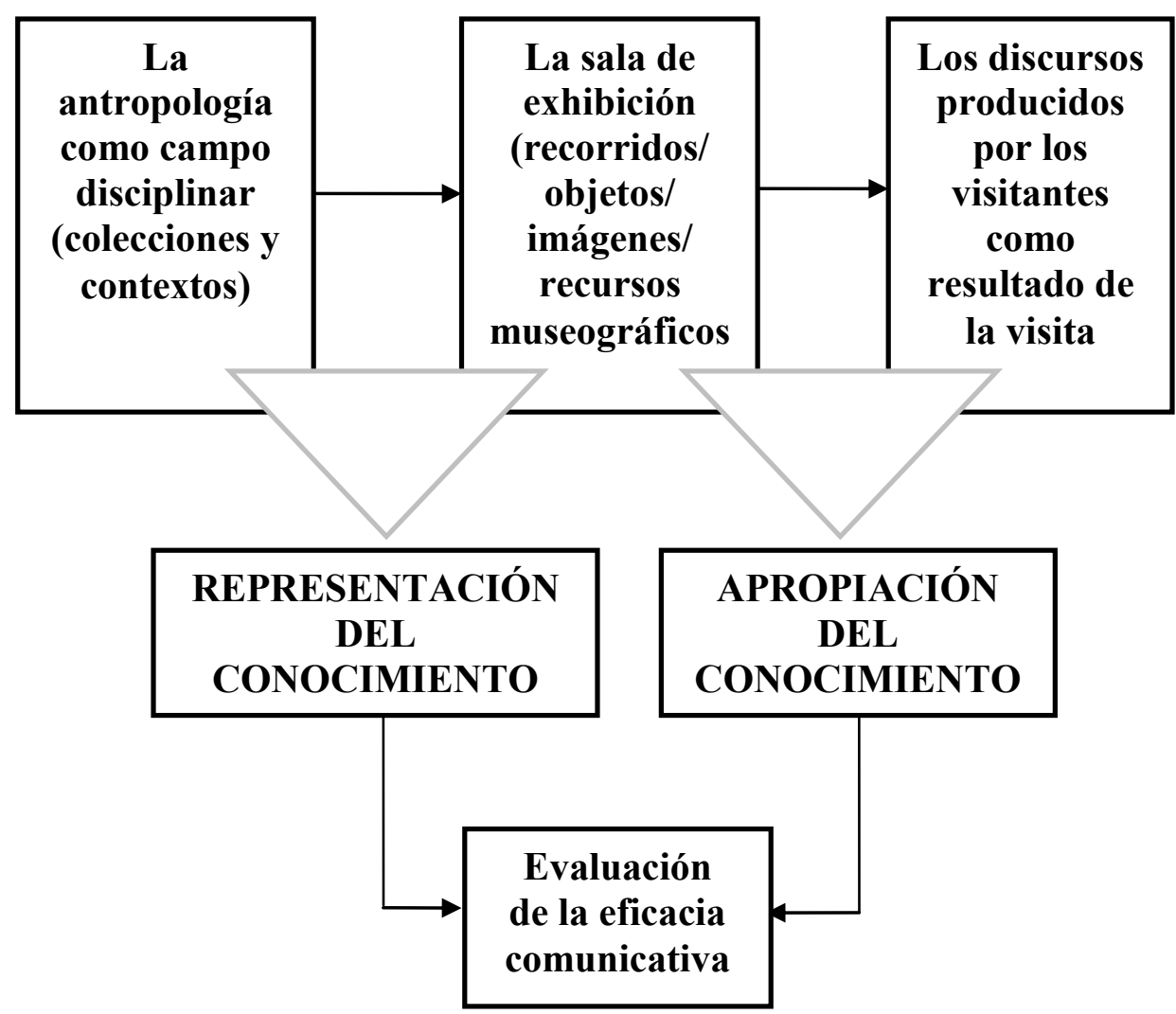

En todas las instancias relacionales se busca explicitar los criterios teóricometodológicos por los cuales se establecen dichas relaciones y la arquitectura lógica desde donde se gesta el proceso de interpretación.

La organización de los contenidos está estructurada en siete capítulos. El primero se refiere a los lazos que históricamente han tenido los museos con la antropología, particularmente en las primeras etapas del nacimiento de esta disciplina. Se analizan algunos supuestos que subyacen a esta relación en el marco de las exhibiciones etnográficas. A su vez, la caracterización del museo decimonónico permite enmarcar al Museo de La Plata como un exponente emblemático de las ideas de ese momento.

El segundo capítulo recupera el concepto de representación en el marco de los nuevos paradigmas para instalar esta cuestión en el centro de la discusión antropológica en torno a la construcción de una teoría. Se presentan estos argumentos como un desplazamiento disciplinar hacia nuevos supuestos. Este análisis viene acompañado de 
la caracterización de los nuevos modelos expositivos, que emergen hacia una perspectiva abierta e interactiva, desplazando su centro de atención desde el objeto hacia los receptores/visitantes.

En el tercer capítulo se asume una mirada semiótica, identificando tres contextos de significación por los que circula el objeto de colección etnográfico y en los cuales es posible reconocer los intérpretes y los fundamentos que darán al mismo su valor de signo. Las relaciones entre estos contextos, denominados respectivamente de recolección, de re-presentación y de apropiación, definen el lugar de las estrategias de "producción de sentido" y el carácter mediador del contexto de re-presentación.

En el cuarto capítulo se describe la exhibición permanente de etnografía del Museo de La Plata, llamada "Espejos Culturales". Se explicitan los criterios y niveles de organización, los contenidos y los recursos expositivos para poner en evidencia el conjunto de supuestos e intenciones que movilizaron la innovación.

Los capítulos cinco y seis se relacionan directamente con los llamados estudios de visitantes a museos para abordar el contexto de apropiación. A partir de una aproximación cualitativa, se analizan los discursos producidos por los visitantes/intérpretes como consecuencia de la visita a la sala de exhibición. La semiótica simbólica y el análisis de discurso son el marco teórico de los aspectos metodológicos. Los datos son procesados a través de herramientas informáticas diseñadas para métodos cualitativos. Este análisis permite construir el conjunto de categorías, atributos y relaciones que configuran los mundos semióticos posibles y, a posteriori, evaluar la eficacia comunicativa de la sala motivo de este estudio.

Las consideraciones finales recuperan las nuevas propuestas para los museos y las reflexiones teóricas de la antropología y los materiales etnográficos para reflexionar en torno a una "ética de la re-presentación". 
Capítulo I

ANTROPOLOGÍA Y MUSEOS 


\section{Capítulo I: ANTROPOLOGÍA Y MUSEOS}

\section{I.1. El origen de los museos: antecedentes de los museos de antropología}

Desde su creación, los museos han experimentado una serie de transformaciones paradigmáticas en el marco de los diferentes contextos surgidos del análisis histórico, social, político y epistemológico. Muchas de las reflexiones que hoy impregnan los debates y reformulaciones de este tipo de instituciones se configuran con referencia a su concepción en el pasado. Desde sus inicios, los museos acompañaron el desarrollo de distintas áreas del conocimiento, entre ellas la antropología, estableciendo intrincadas relaciones entre sus prácticas y representaciones, aportando, con distinta intensidad, a la constitución de un campo disciplinar. ${ }^{1}$ Si bien, la revisión exhaustiva de la historia de los museos y la conformación de las colecciones no es el objetivo central de esta tesis, entender el presente de estas instituciones implica no ignorar las herencias del pasado.

En este marco, las exhibiciones, concebidas como construcción discursiva ${ }^{2}$ aparecen como el lugar de la enunciación donde se materializa el ideario de los distintos momentos. A su vez, las transformaciones experimentadas en el tiempo de las distintas modalidades expositivas, elemento identitario de la institución museo, contribuyen a la construcción de esta historicidad.

A través de las exhibiciones el museo hace público el saber científico y antropológico, se expone a la mirada crítica tanto de la academia como de la sociedad en general. Esta práctica, característica y definitoria del museo, ha estado ligada

\footnotetext{
${ }^{1}$ La noción de campo ha sido planteada por Bourdieu para dar cuenta del conjunto de relaciones objetivas en las que históricamente se encuentran ubicados los agentes y con la cual intenta sobrepasar las arbitrarias oposiciones entre estructura e historia, entre conservación y transformación. El campo es un espacio estructurado cuyas propiedades depende de las relaciones y posiciones de sus agentes. En él se gestan relaciones de fuerza y autoridad, según la distribución del capital específico. Se trata de un sistema regido por sus propias leyes.

2 ... "toda activación comporta un discurso, más o menos explícito, más o menos consciente, más o menos polisémico, pero absolutamente real. Este discurso se basa en unas reglas gramaticales sui generis que son: la selección de los elementos integrantes de la activación, la ordenación de estos elementos (como equivalentes a la construcción de las frases de un discurso) ; y la interpretación (o restricción de la polisemia de cada elemento-palabra mediante recursos diversos, desde el texto a la iluminación, o la ubicación) (...) El objetivo, con frecuencia implícito, de la negociación, es alcanzar el mayor grado de consenso posible, de manera que el discurso subyacente en la activación aparezca legitimado y conforme a la realidad socialmente percibida." (Prats, 2005). Comparten esta perspectiva Deloche, B. (2002) y Zunsunegui, S. (2003).
} 
históricamente a los paradigmas epistemológicos, a los contextos sociopolíticos y a las disciplinas desde donde se tipifican las colecciones.

El museo, tal como lo entendemos hoy, es una construcción moderna, es producto de la Modernidad. Según Teruggi (1994), nació en Francia, en el Jardín Royal des Herbes Mèdicinales, creado por Luis XIII en 1626. Luego, en 1793, durante la Convención este sería transformado en el Museum National d'Historie Naturelle. Por otra parte, el Museo Británico, dedicado fundamentalmente a la arqueología, la etnografía y la historia, había sido inaugurado en 1759. Habría que esperar hasta 1881 para que de éste se inaugurase separadamente una rama especializada en las ciencias naturales.

Sin embargo, no se mantuvo en Europa por mucho tiempo el modelo de un museo único para todas las ciencias naturales. Luego de que el Museo Nacional de París dividiera las secciones en cada reino de la naturaleza y a sus restos fósiles, el modelo fue aceptado en todo el Viejo Mundo.

En el marco de esta expansión global de los museos, el mayor desarrollo en lo que atañe a las ciencias naturales ocurrió en los Estados Unidos. En menos de treinta años, tres grandes museos fueron inaugurados: el Museo Americano de Historia Natural de Nueva York, fundado en 1869; el Museo Nacional de Historia Natural de Washington en 1879 y el Museo de Historia Natural de Chicago que data de 1893. A diferencia de la situación europea, en estos museos, además de mantenerse la unidad, se incorporaron las ciencias del hombre: arqueología, etnografía y antropología. De este modo, se ven diferenciados, ya, dos paradigmas diferentes; uno que apunta a la ampliación del campo y a su unidad, el caso de los Estados Unidos, y otro que sostiene una diferenciación entre las ciencias naturales y las de el hombre, el caso de Europa.

El origen de los museos hay que entroncarlo en dos hechos importantes: el Coleccionismo y la Ilustración. El coleccionismo es considerado en tanto origen de todos los museos, ya que estos han partido de las llamadas "cámaras de maravillas", "cámaras artísticas", "gabinete de curiosidades"; colecciones privadas de aristócratas y monarcas. Por otra parte, la Ilustración se entiende como el pensamiento que impulsó el nacimiento de los grandes museos europeos. ${ }^{3}$ Con el traspaso del patrimonio cultural de

${ }^{3}$ Si bien "el primer museo organizado como institución pública fue el Ashmolean Museum de Oxford, creado en 1683, no es, sin embargo hasta 1793, fecha de inauguración del Louvre, cuando se considera que han nacido los grandes museos europeos ya que aparece un nuevo concepto de propiedad 
colecciones privadas de propiedad exclusiva a patrimonio nacional del Estado se considera, en Europa, que han nacido los museos, para los cuales es el pueblo quien debe ser el usufructuario del patrimonio cultural.

El Museo moderno surge, entonces, en un momento preciso de la historia, fines del siglo XVIII, producto de una ruptura conceptual articulada en el paso del coleccionismo privado al desarrollo de un proyecto pedagógico-informativo de carácter público, generalizado en el siglo XIX. Fue esta una conquista de los sectores burgueses, que se vio fuertemente impulsada en el contexto de la Revolución Francesa y que logró su expansión global junto con el avance de la industrialización y de la educación común.

La formación de los museos públicos se remite al modelado de nuevos espacios de representación, propio del paso de la episteme renacentista a la episteme clásica y, posteriormente decimonónica. Asociados al desarrollo de nuevas formas de gobierno, al nacimiento de los Estados Modernos, una reorientación del saber que se remonta al siglo XVI, se activan nuevos modos cognoscitivos que contribuyen a la producción de nuevos campos de conocimiento y a la instalación de nuevas ciencias humanas. "El museo se inserta de manera natural, como un sistema de representación más, en el conjunto del imaginario social en tanto institución cultural propiciada y amparada por el Estado-Nación: la formación de los modernos estados es acompañada por una serie de acciones, en campos muy diversos, encaminadas a otorgar "señas de identidad colectiva" unitarias a los grupos sociales embarcados en el nuevo proyecto de vida común, a través de la idea de patrimonio colectivo artístico, a esta construcción ideológica" (Zunzunegui, 2003:39).

Frente a la fascinación por lo raro o curioso, propio de una racionalidad precientífica, infatigablemente volcada hacia una naturaleza variable, diversa y analógica, y cuyas articulaciones de objetos responden a un saber enciclopédico, los principios de la racionalidad científica orientan la atención hacia las recurrencias de las que pueden dar cuenta las leyes científicas. La colección museística da prioridad así a las series de cosas morfológicamente ordenadas (Pazos, 1998). Con el sustento del paradigma científico positivista, el museo deja de ser el lugar de lo curioso, para ser el lugar de un conocimiento ordenado en colecciones, exhibiciones permanentes,

respecto del patrimonio cultural del país, considerando al pueblo como usufructuario de dicho patrimonio (Hernández, 1992). 
respondiendo al criterio de la racionalidad. Abandonando la episteme renacentista, no dominada por la ciencia, esos "gabinetes de curiosidades" 4 pasaron a constituirse como los lugares privilegiados para legitimar los proyectos estatales de modernización, bajo nuevos criterios de representatividad. Las colecciones depositadas en los museos públicos, evocando a otros mundos, desdibujan la figura individual del coleccionista y dan paso a la creación de una ficción de igualdad entre visitantes conformadores de una nación. Como afirma Podgorny "esconderían de la vista de los espectadores las desigualdades sociales y el mundo en el que están inmersos" (Podgorny, 2005:240).

"Un museo moderno implica, por un lado, una relación estable o permanente entre la colección y el espacio público donde se exhibe; por otro, el pasaje del deleite y la contemplación privada de los tesoros personales a una publicidad y un orden creados por el mismo museo: por eso, como señala Forgan (1994), la continuidad entre aquellos museos renacentistas y los museos del siglo XIX es solo aparente. Entre ellos media una historia de emergencia y desaparición de las prácticas, ideas o hábitos asociados a estos espacios que complican el trazado de una línea continua entre unos y otros. (...) Los museos proliferaron en el siglo del progreso y, entre ciertos sectores medios del mudo burgués, se soñaba con la posesión de un museo en algún cuarto de la casa, emulando el estilo de los gabinetes del filósofo natural de los inicios de la modernidad. Por ello, la definición de "un museo", tan certera para los manuales contemporáneos, se vuelve un poco más esquiva al acercarse al mundo de los aficionados a la historia natural, a los coleccionistas y a los científicos de la época.” (Podgorny, 2005:236)

\section{I.2. La realidad como objeto y el objeto real como evidencia}

El museo tradicional funciona como legitimador de ideologías, de sistemas de valores. Éste se entendió desde sus orígenes como el garante de una imagen del hombre. “Desde esta perspectiva es evidente que se le adjudicó a la vez una función identitaria y patrimonial, pues es el lugar en el que voy a apropiarme simbólicamente de la obras de la humanidad para conseguir yo mismo ser plenamente humano. Al seleccionar

\footnotetext{
${ }^{4}$ El gabinete de curiosidades del humanista renacentista, comúnmente aceptado como el prototipo del museo moderno, emergió en forma contemporánea con la era del descubrimiento y la exploración, desde el momento en que Cortés envió piezas desde México luego de la Conquista, las curiosidades tanto artificiales como naturales provenientes del Nuevo Mundo y en Oriente tuvieron lugar en ellos. (Sturtevant 1969, citado por Stoking, 1985).
} 
rígidamente y aislar los objetos que tiene que proteger en tanto que testigos de lo humano, el museo pasó a ser el motor de cambio, se transformó en lugar de culto, en máquina de fabricar lo sagrado, hasta el punto de olvidar su misión elemental de comunicación. (...) sacralizar es, pues, poner aparte, aislar la imagen del hombre, ese instrumento de su identidad espiritual. (...) Esta aspiración oficial a la universalidad de la cultura encubre, en realidad, fines muy poco universales que, en concreto, pretenden mantener el sistema de valores de la cultura occidental, fines que, en esencia, consisten en estereotipar un concepto del hombre como si fuera único y definitivo, lo que se traduce, en primer lugar, por ese culto idólatra del arte que con tanto lirismo expresó Malraux. (...) Esta es una de las figuras principales del imperialismo occidental: imponer al mundo entero su sistema de valores, su ideología de persona." (Deloche, 2003: 87).

La modernidad confiaba plenamente en la razón, herencia del Iluminismo. En ella está el origen del conocimiento "verdadero" y el descubrimiento de las leyes de la naturaleza. Las regularidades observables y el carácter objetivo del conocimiento otorgaban valor predictivo al comportamiento y, en consecuencia, la posibilidad del control y la manipulación. ${ }^{5}$

La experimentación, la mensurabilidad y la demostración axiomática y formal eran algunos de los criterios de demarcación del conocimiento científico. El correlato de este conocimiento en las salas de exhibición dejaba poco espacio para el debate. La fuerza del paradigma naturalista del siglo XIX estructuró una visión del mundo basada en el orden, la previsibilidad, el control. "Cuando Weber dice "desencantemiento del mundo" hace referencia a la constitución de la naturaleza como mero objeto de conocimiento o de uso, su absoluta profanación, su pérdida de sacralidad, de misterio. Es decir, lo oscuro, lo otro, lo sagrado de la naturaleza queda absolutamente despojado a partir de la irrupción de la mirada helada de la racionalidad instrumental. La naturaleza como espacio de sombras, como espacio de vitalidad, como otro lleno de misterios, vertida, en el mejor de los casos, en una estructura cuantificada, en un ámbito para ser

\footnotetext{
5 "El Museo aparece, desde un principio, como un campo de ejercicios sintácticos que propone una mediación entre los valores sociales fundamentales presentes en las obras de arte y los espectadores. Es, pues, evidente que estamos ante el ejercicio de una estrategia institucional de comunicación que busca el hacer (sentir, pensar, saber, querer) del público "usuario" del museo para educarle, instruirle y emocionarle, poniendo a su alcance y permitiéndole participar de los valores encarnados en el patrimonio artístico comunicativo." (Zunzunegui, 2003:49-50).
} 
atravesado por la "luz" de la razón, una luz helada de la razón y también, para ser modificado profundamente por el nuevo arsenal técnico-científico. (...) Esta historia ejemplar o autolegitimada de la razón del siglo XIX, tiene que ver también con esta concepción que definimos como la ideología del progreso - una humanidad que marcha inexorablemente hacia la construcción de un mundo cada vez más perfecto, amparado en el despliegue de la razón, de la técnica y de la ciencia.” (Forster, 1991:149).

En este contexto, el objeto colectado, fragmento de la realidad, ostentaba la condición de evidencia. La observación y la experimentación sustentaban la demostración de las "verdades empíricas". Los museos de ciencias expusieron en sus vitrinas la organización taxonómica del mundo. Numerosos objetos fortalecían las ideas de lo cuantificable, repetible y recurrente. Así el sentido de las cosas viene dado (observado) y se separa de su esencia, de su ser inmutable para instalarse en la objetividad de lo evidente. Los museos, acompañados de la monumentalidad de sus edificios, se constituyeron en espacios de autoridad y las exhibiciones en el dispositivo que hizo visible y pública esa autoridad, legitimada en el conocimiento positivo del mundo.

Se reconocen dos grandes discontinuidades en la episteme de la cultura occidental: aquella con la que se inaugura la época clásica (hacia mediados del siglo XVII) y aquella que, a principios del XIX, señala el umbral de nuestra modernidad. La función natural con la cual el lenguaje representa al mundo, pretensión de totalidad y universalidad. Lo que caracteriza a la modernidad es esa relación sublime entre lo presentable con lo concebible. (Lyotard, 1992).

En Las palabras y las cosas, Michel Foucault analiza cómo las condiciones de positividad, propia de la episteme clásica, cambia profundamente, desaparece la teoría de la representación como fundamento general de todos los órdenes posibles; se desvanece el lenguaje en cuanto tabla espontánea y cuadrícula primera de las cosas, como enlace indispensable entre la representación y los seres. A cambio se instala un principio de inteligibilidad y abandono del espacio de la representación, el hombre a su vez entra en el campo del saber occidental. El conocimiento se vuelve objetivo en la medida en que el dominio de la representación está limitado de antemano. La representación "se duplica": representaciones cuyo papel es designar las representaciones, analizarlas, componerlas y descomponerlas para hacer surgir en ellas, 
con el sistema de sus identidades y de sus diferencias, el principio general de un orden. (Foucault, 1996).

La representación en el positivismo se desplaza de la esencia al fenómeno: "se ofrece a la experiencia toda una capa de fenómenos cuya racionalidad y encadenamiento reposan sobre un fundamento objetivo que no es posible sacar a luz; no es posible conocer la sustancia, sólo los fenómenos; no las esencias, sino las leyes; no los seres, sino las regularidades. Así se instaura, a partir de la crítica (...) una correlación fundamental, por un lado, las metafísicas del objeto, más exactamente las metafísicas de ese fondo, nunca objetivable, de donde llegan los objetos a nuestro conocimiento superficial; las filosofías que se proponen como tarea la sola observación de aquello mismo que se ofrece a un conocimiento positivo." (Foucault, 1996:240).

Para Foucault los museos y las bibliotecas son heterotopías ${ }^{6}$ propias de la cultura occidental del siglo XIX. Lugares localizables, donde se yuxtaponen distintos tiempos y espacios y donde subyace la idea de acumular todo, de establecer una especie de archivo general, la voluntad de constituir lugares de todos los tiempos que están en sí mismos fuera del tiempo e inaccesibles a sus estragos, el proyecto de organizar de esta forma un tipo de acumulación perpetua e indefinida en un lugar inmóvil, esta idea total pertenece a nuestra modernidad.

Pero el museo concebido como heterotopía no puede ser pensado por la presentación de diferentes objetos o por la yuxtaposición de diferentes épocas, sino por una consideración más profunda acerca de la naturaleza de la diferencia, aquella que existe entre los objetos y los conceptos. Es allí donde se sitúa la representación/ interpretación.

Como espacio de representación, entonces, el museo es un espacio de diferencia. El museo de Foucault no es un depósito funerario de objetos de distintas épocas, sino una experiencia de la brecha entre las cosas y el orden conceptual y cultural en el que se interpretan. (Señor, 2006).

\section{I.3. La antropología como disciplina y la representación del Otro cultural en las salas de museo}

\footnotetext{
${ }^{6}$ A diferencia de la utopía, la heterotopías son lugares reales, localizables.
} 
Los museos de etnografía han jugado un rol primario en el nacimiento y el desarrollo de la disciplina. Sin embargo, el sustento didáctico, metodológico y epistemológico que los museos han podido constituir, en la actualidad se ha debilitado e incluso suplantado por centros y laboratorios que han roto todo lazo con la aproximación museológica propiamente dicha (Jamin, 1998).

Los museos o exhibiciones de carácter antropológico -en particular los etnográficos- se constituyeron, desde sus inicios, como los espacios legítimos de representación de otras culturas. Las recolecciones se circunscribieron a las sociedades no occidentales, objeto de estudio de la etnografía clásica, y la cultura material el reflejo de las diferencias identitarias. Esta forma de identidad, ya sea cultural o personal, presupone el acto de la colección; es decir, una reunión de propiedades en sistemas arbitrarios de valor y significado. Estos sistemas han cambiado históricamente pero siempre son poderosos y gobernados por reglas (Clifford, 1985).

La historia de los museos y las relaciones recíprocas entre la teoría antropológica y su proceso de institucionalización aporta a nuestro análisis la comprensión de los resortes teóricos, epistemológicos y políticos que directa o indirectamente sostuvieron las distintas formas de representación en los museos. Los primeros museos de antropología fueron el ámbito natural del desarrollo de investigaciones y trabajos de campo. Intensas relaciones se establecieron entre los principios teóricos de la antropología y su traslado a las salas de exhibición.

Los museos clasificados como etnográficos o aquellos que albergan entre sus colecciones objetos pertenecientes a la cultura material de los pueblos etnográficos se rigen bajo el ideario de la modernidad. La modernización del mundo significa que el mundo es, sobre todo, la representación que nos hacemos de él. ${ }^{7}$

En el Museo Moderno Occidental la ilusión de una relación entre las cosas toma el lugar de una relación social. El coleccionista descubre y adquiere objetos salvajes. El mundo objetivo está dado, y de este modo se ocultan las relaciones históricas de poder en los trabajos de adquisición. La producción de significado en la clasificación y exposición de museo está mistificada como una representación adecuada. El tiempo y el

\footnotetext{
7 "La Modernidad es ese proceso de racionalización que esencialmente se va a dar en Europa Occidental y en sus hijas dilectas que son las Américas. Proceso de racionalización como forma de comprender pero al mismo tiempo de estructurar el mundo, la historia y el lugar del hombre en esa historia. Proceso de racionalización que suple a ese viejo representar religioso, y que Weber va a llamar el "desencantamiento del mundo." (Casullo, 1999:17).
} 
orden de la colección pasa por alto y borra la labor social concreta de su realización (Clifford, 1985).

Históricamente, se reconoce un primer período que se ha dado en llamar "de los museos" como expresión de esta indisoluble vinculación, entre los años 1840 y 1890 (Sturtevant, 1973). Posteriormente, se asume internacionalmente, un período de decadencia o declinación a partir de las décadas del 20 y 30, para revitalizar los estudios en museos, bajo nuevas miradas y preceptos a partir de la década de 1980 (Stoking, 1985; Carretero Pérez, 1996; Moritz Schwarcz, 1993).

Algunos museos siguieron el patrón del Peabody, enfocándose en la etnología y arqueología prehistórica, otros, especialmente en Europa continental, fueron museos de la cultura nacional y campesina en la tradición Volkskunde. En algunos casos, las exhibiciones antropológicas fueron un departamento dentro de un museo nacional general, o especialmente en América del Norte, de un museo de Historia Natural, otros crecieron a partir de ferias o exhibiciones internacionales (Stoking, 1985). ${ }^{8}$

Históricamente, se reconoce un primer período que se ha dado en llamar "de los museos" como expresión de esta indisoluble vinculación, entre los años 1840 y 1890 (Sturtevant, 1973). Posteriormente, se asume internacionalmente, un período de decadencia o declinación a partir de las décadas del 20 y 30, para revitalizar los estudios en museos, bajo nuevas miradas y preceptos a partir de la década de 1980 (Stoking, 1985; Carretero Pérez, 1996; Moritz Schwarcz, 1993).

La antropología aparece como disciplina científica, muchas veces asociada a los estudios de colecciones de Historia Natural y Antropología Física. Como afirma Carretero Pérez (1996) la mayor parte de los fundadores o promotores de tales museos no fueron ni mucho menos antropólogos culturales o etnólogos, sino médicos o naturalistas que ampliaban su campo de estudio de lo biológico a lo cultural, que trataban de acompasar los dos evolucionismos.

El conocimiento de otras culturas está mediatizado por el antropólogo/etnógrafo que, a partir de una situación de contacto, elemento estructurante del quehacer

\footnotetext{
8 En tres de las tradiciones antropológicas, un escenario institucional más característico fue quizás la Sociedad Etnológica fundada en París en 1839, en Nueva York en 1842, y en Londres en 1843. Mientras que para ese momento los materiales etnográficos eran incluidos en las colecciones de museos de cada uno de estos países, el establecimiento de sus principales museos antropológicos sólo comenzó con la fundación del Museo Peabody de Arqueología y Etnología en 1855” (Stoking, 1985).
} 
etnográfico, persigue el objetivo de observar, describir, registrar, colectar, interpretar y representar su modo de vida. El problema de la representación adopta connotaciones particulares, muchas de ellas de carácter ético, desde el momento que su objeto de estudio es el sujeto. Alcanzar los parámetros científicos propios de las ciencias naturales - objetividad, experimentación, manipulación, control de las condiciones de producción del conocimiento, entre otros- será una aspiración particularmente problemática para la antropología.

"El museo de antropología es una forma de producción de conocimiento que, como tal, traduce en formas de ordenamiento y exposición de objetos las líneas teóricas, los conceptos y las formas discursivas fundamentales de la antropología. Cualquiera de los problemas técnicos relativos a la disposición de objetos está atravesado por consideraciones de carácter más general relativas a la relación del objeto con un sistema cultural ajeno o propio, y a las posibilidades que tienen las formas de representación de la institución museística de restablecer esta integridad.” (Pazos, 1998:33). ${ }^{9}$

\section{I.4. La cultura exótica: el evolucionismo y el particularismo en las salas de exhibición}

El "Otro", objeto de estudio de la antropología, nace con el concepto asociado de lo extraño, lo exótico y lo lejano, bajo la mirada etnocéntrica y europea. El conocimiento del pasado y de las sociedades indígenas, adoptaba ciertas características en el estudio de las identidades, acompañado de un marco científico racional que pretendía, bajo el precepto de la exhaustividad y el extrañamiento, lograr la certeza o veracidad del conocimiento producido a partir del trabajo de campo. Es este el período de mayor incremento de colecciones de objetos "exóticos" de culturas "lejanas", cuyas modalidades de adquisición se sustentaban en un conocimiento científico positivo. Éste encontraba su correlato en las vitrinas de las salas de exhibición. Allí, la identidad,

\footnotetext{
9 "En efecto, las comunidades que aspiran hoy a superar los antiguos usos del museo pueden estar condenándose a repetir las operaciones esencialistas de los museos etnográficos tradicionales. Lejos de cuestionar realmente la función representativa de la institución, se retoma su valor de imagen para la reflexión narcisista o para el adoctrinamiento político y cultural. Se obvia, de esta manera, la problemática que hace tan semejantes las trayectorias de los museos y de la antropología: si se puede hablar de esta paralelismo es no sólo porque desde sus orígenes el museo etnográfico ha ilustrado y conformado incluso las teorías etnológicas, sino porque en la actualidad las formas de representación museística se enfrentan a los mismos dilemas que los conceptos teóricos.” (Pazos, 1998:34).
} 
reducida a la cultura material, se presentaba en la definición de un conocimiento acabado, fijo y estandarizado. Los parámetros espacio-temporales constituyeron los ejes organizativos de la diversidad, recortando bajo un sentido de "cultura pura" el lugar de la identidad.

El sujeto que está detrás de los objetos exhibidos es caracterizado como portador de una cultura simple y en extinción que, por un lado hay que rescatar o resguardar acrecentando las colecciones de los museos y, por otro, hay que conquistar, civilizar. Ese "Otro" cultural, será considerado por la etnografía no solo en cuanto a su cultura material, que aparece como la poseedora del poder evocativo en los museos, sino también en cuanto a su estructura física, sistemas de creencias, formas de organización familiar, entre otros tópicos de la sistemática cultural.

Fueron dos los marcos teóricos explícitos de este período. El evolucionismo, que construyó a ese "otro" cultural objeto de estudio desde la diferencia (el "otro" como diferente a un nosotros) y el particularismo histórico en el que la "otredad cultural", atravesada por el principio de relativismo cultural y los estudios comparados, se configuró como diversidad. ${ }^{10}$

Las teorías evolucionistas de fines del siglo XIX, se trasladaron al análisis de las culturas asociadas a una idea de linealidad y de progreso hacia la civilización. Así las culturas no occidentales fueron organizadas en estadíos de lo más simple a lo más complejo. Concebidas como "simples", "primitivas", "salvajes” o "bárbaras”, ocupaban los primeros escalones de este ascenso a la civilización testimoniando los estadíos primarios de la evolución de la humanidad.

Las teorías relativistas instalan una fuerte crítica al evolucionismo, inicialmente el particularismo histórico de Boas ${ }^{11}$. El principio de relativismo cultural surge de la

\footnotetext{
${ }^{10}$ Boivin define tres momentos constitutivos de la Antropología en Europa y Estados Unidos. Momentos en los cuales se desarrollaron teorías que fueron dominante y que definieron y explicaron de manera distinta el quehacer antropológico. "El primero de ellos surge a fines del siglo XIX en donde la Antropología se constituyó como ciencia y la teoría que logró dominar el discurso antropológico fue el evolucionismo. El segundo momento fue el que se desarrolló entre las dos guerras mundiales y se caracterizó por la diversidad de teorías que tuvieron en común el intento de explicar la diversidad cultural. Y el tercer momento, que comienza luego de la Segunda Guerra Mundial, en el cual las teorías anteriores todavía siguen siendo dominantes pero aparecen las "otras", las "no occidentales" que plantean teorías alternativas sobre la otredad cultural.” (Boivin, 2007:7).

${ }^{11}$ “Entre las dos guerras mundiales, en la antropología europea y norteamericana se producen dos hechos importantes: la crisis del evolucionismo como paradigma único y la separación de la ciencia en escuelas nacionales; aparecen así el estructuralismo y el funcionalismo inglés, el partiacularismo histórico en Estados Unidos, la escuela histórico-cultural en Alemania y la escuela sociológica francesa. Cada una
} 
observación de la cultura como totalidad, como un conjunto de partes indisolublemente unidas, en la que cada una de ellas tiene relación con el todo. Así, se tornaba imposible la operación de abstraer una parte de ese todo y encontrar los fundamentos del análisis comparativo con sentido evolutivo. El análisis contextual de cada cultura desterró definitivamente al etnocentrismo de la teoría antropológica e inauguró la mirada relativista.

Las ideas teóricas y los mensajes ideológicos que se querían transmitir o que parecen haber sido transmitidos mediante la disposición de los objetos materiales para ser vistos por diversos públicos, fueron explícitamente declaradas por las agendas del general Pitt Rivers y Franz Boas. Uno disponía los objetos linealmente, en términos de cualidades formales o funcionales definidas externamente, para transmitir un mensaje etnocéntrico de gradualismo evolutivo conservador. El otro los disponía contextualmente, buscando preservar las múltiples funciones y significados internos de una forma dada, para transmitir un mensaje de relativismo liberal (Carretero Pérez, 1996).

De acuerdo con Pazos (1998) el prototipo de museo de esta época sigue siendo el de Pitt-Rivers. Descontextualizados de sus marcos culturales originales, los objetos, eran sometidos a una ordenación de series evolutivas que van desde lo simple a lo complejo, permitiendo así una visualización del ideario evolucionista.

Por el contrario, el particularismo histórico pondrá énfasis en los contextos particulares en que se inscriben los objetos. Las culturas son igualmente circunscriptas a lo lejano, lo exótico y puro, pero bajo la mirada relativista.

El cambio producido a partir de los estudios de Boas, en lo que respecta a la actividad museística, resulta de la recepción del objeto más allá de su estricta materialidad, funcionalidad y utilitarismo. El interés de Boas es el del deslizamiento de la forma hacia el sentido. De acuerdo al holismo cultural, la colección debe representar la vida total de la tribu, el museo debe organizarse de acuerdo a un ordenamiento tribal, y no tipológico, de los objetos. Se trata, por tanto, de introducir en el museo escenas de la vida tribal como ejemplo de las redes culturales en que los artefactos deben contextualizarse. Este es el papel de las presentaciones con maniquíes en escenarios realistas, como técnica adecuada para la descripción de significados y funciones locales.

elaboró teorías alternativas, muchas veces sin contacto entre ellas, pero todas tuvieron en común la crítica al evolucionismo." (Bovin, 2007:10). 
Las representaciones de escenas, pretendían restituir las formas de vida, se enmarcaban en las características propias del realismo espectacular: cuanto más conseguido fuera el efecto de verosimilitud más reproducía al público su valor pedagógico (Jackins, 1985).

Las monografías etnográficas o informes de campo se esmeran en reproducir con exhaustividad la vida total del grupo. La observación participante es el método por excelencia de la etnografía. El etnógrafo participa como un actor más de la vida cotidiana del grupo de estudio, con quienes busca establecer un vínculo (rapport), que resulte en un aporte a la fidelidad y autenticidad del conocimiento logrado.

La primera instancia de representación es ese informe de campo, fotografías y otros registros de primera mano. Las etnografías realistas, recurren a una retórica con la cual se alude a un todo por medio de las partes. Los temas de tratamiento analítico constantemente evocan una totalidad social y cultural. La escritura realista describe en forma minuciosa y con detalle poniendo de manifiesto que el escritor compartió y experimentó todo ese mundo cultural distinto. De hecho, lo que da al etnógrafo autoridad y al texto una ubicua impresión de realidad concreta, es la pretensión del autor de representar un mundo como solo puede hacerlo el que lo conoce de primera mano, lo cual forja un vínculo íntimo entre la escritura y el trabajo de campo etnográfico (Geertz, 1989; Clifford, 1991).

El propósito de evocar en el museo la cultura, en tanto que red simbólica o vida práctica habitual, ha llevado desde Boas a trabajar técnicas que incluyen el añadido de fotografías y el perfeccionamiento de escenas (en vitrinas) con dioramas. Estas formas de escenificación se sustentan en imágenes prototípicas y simplificadoras de la sociedad representada. Si bien es una instancia superadora de la organización taxonómica del modelo evolucionista, en esta retórica de la metonimia la vida de toda la población queda resumida en una o dos escenas, una o dos actividades a las que se reduce toda la complejidad característica del transcurrir cotidiano de las culturas.

Bajo los preceptos del particularismo la presentación museística de la cultura era pensada como conjuntos sistemáticos de comportamientos, totalidades homogéneas y sincrónicas.

La práctica etnográfica sufrió profundos cambios en la transición de la visión decimonónica de una ciencia antropológica del Hombre a una intensa reorganización en el 
siglo XX. "Las ambiciones generalistas de la antropología social y cultural fueron redefinidas, dentro de la práctica de la etnografía de dos maneras. En primer lugar, se atenuó la tendencia del siglo XIX a formular enunciados globales absolutos. Como etnógrafo, el antropólogo centra sus esfuerzos en un holismo de una especie distinta: no para formular enunciados universalmente válidos, sino para representar lo más plenamente posible, un modo de vida particular. (...) La esencia de la representación holística en la etnografía moderna no ha sido producir un catálogo o una enciclopedia (...) sino contextualizar los elementos de una cultura y establecer entre ellos relaciones sistemáticas.

En segundo lugar, la dimensión comparativa de la visión global de la antropología dejó de encuadrarse en un esquema evolucionista o de orientarse a la medición del progreso relativo por referencia a valores racionales, aún cuando la comparación quedó incorporada a la retórica de todo texto etnográfico.” (Marcus y Fischer, 2000:49).

El modelo culturalista de museo, de raigambre boasiana, representa culturas únicas, sistemas autónomos de sentido perfectamente diferenciables de otras unidades culturales. Las situaciones de contacto, la interacción entre culturas, los procesos transculturales y de construcción social están ausentes en las vitrinas. La cultura es un sistema cerrado, estático, ahistórico.

La década del 30 marcará el fin de la era de los museos etnográficos como fenómeno mundial. Según Sturtevant (1973) durante el siglo XX decae el interés por la cultura material en los estudios museísticos (Stoking, 1985). ${ }^{12}$

En este proceso de desvinculación disciplinar, son muchos los factores y de distinto orden que intervinieron para que los museos fueran perdiendo interés, desde gestiones deficientes, el contexto conflictivo de las apropiaciones, la pérdida del discurso político que otorgaba al museo la función de consolidar el programa de las Nuevas Naciones hacia la modernidad y, sobre todo la crítica profunda de los paradigmas que fundamentaban la "puesta en escena" de la cultura material de los "otros".

12 ..."Muchos trabajos mencionaron la pérdida de visibilidad de los museos en las primeras décadas del siglo XX frente a otras instituciones científicas y académicas, como los laboratorios y las universidades. Asimismo, la crítica moderna y vanguardista a la cultura basada en el pasado colocó a los museos en un lugar relativamente incómodo: traigamos a la memoria la idea, resonante hasta hace pocos años, de los museos como meros basteones elitistas del conocimiento y del poder. Por ello, entre el esplendor del presente y del siglo XIX media la sentencia de extinción de esas instituciones, carentes de razón de ser en el mundo del futuro.”(Podgorni, 2005:258). 
Compitiendo con la seducción de la inmediatez del trabajo de campo y la ampliación del objeto de estudio hacia la sociedad compleja, el estudio de la cultura material y los museos dejaron de ser espacios relevantes para la investigación. Las salas de los museos quedaron reducidas a la condición de "anticuario" y, con ello, postergada la reflexión en torno a las colecciones y su valor patrimonial.

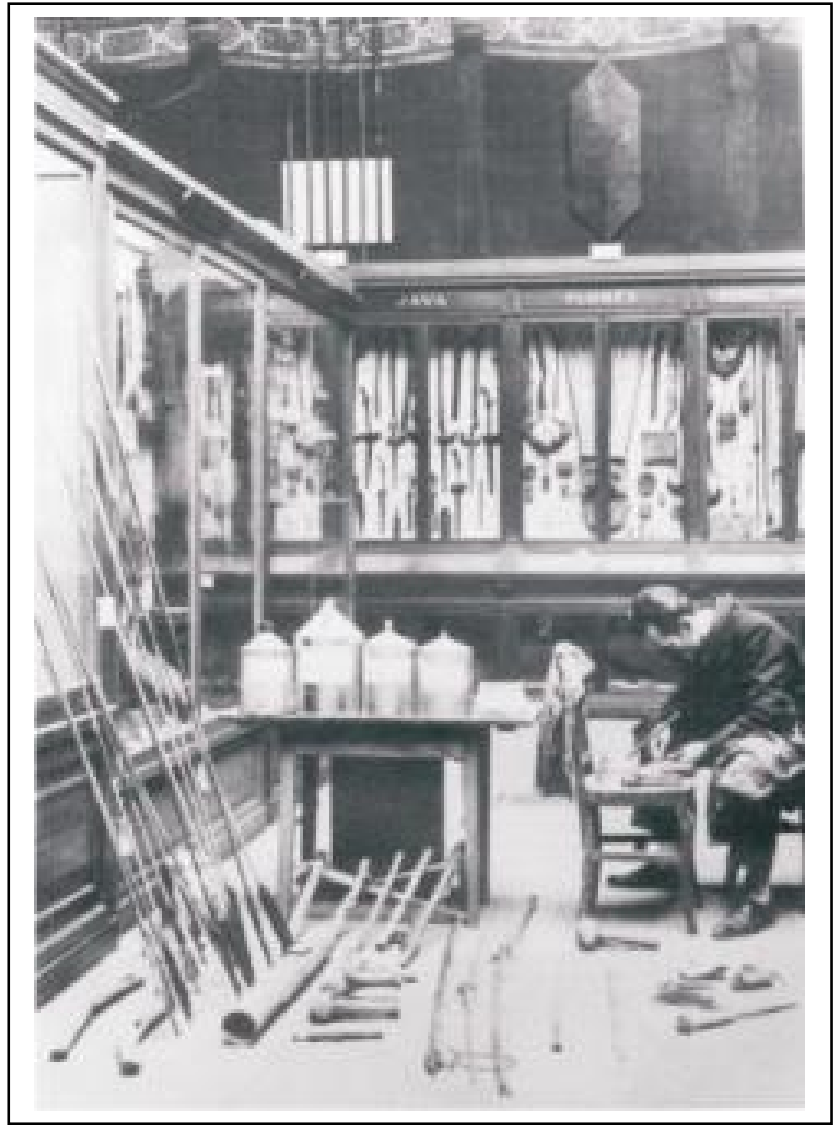

Musée d'Ethnographie du Trocadéro, 1928.

Fuente: Revista Gradhiva, 1998.

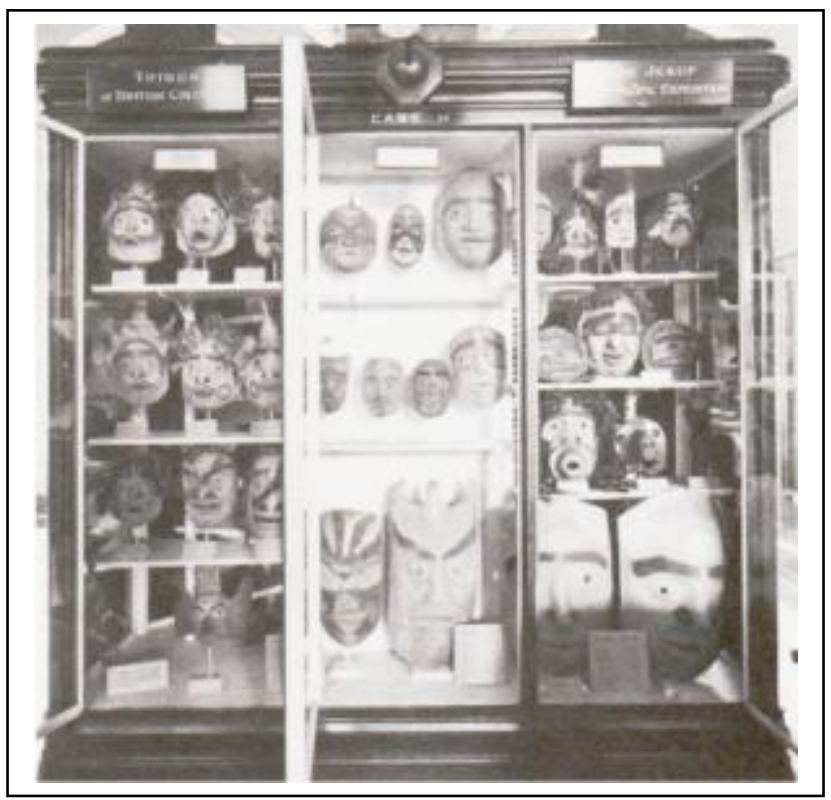

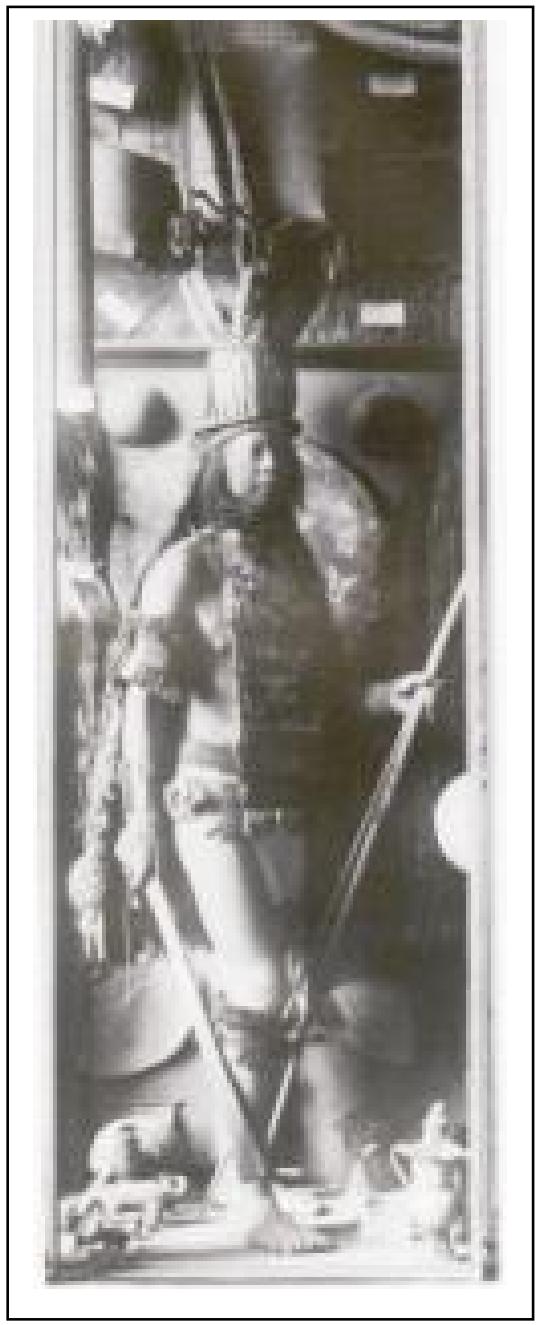

Musée d'Ethnographie du Trocadéro. 1928. Fuente: Rev. Gradhiva, 1998.

Case of Bella Coola in the Northwest Hall, ca.1905 Fuente: Objects and Others, 1985 


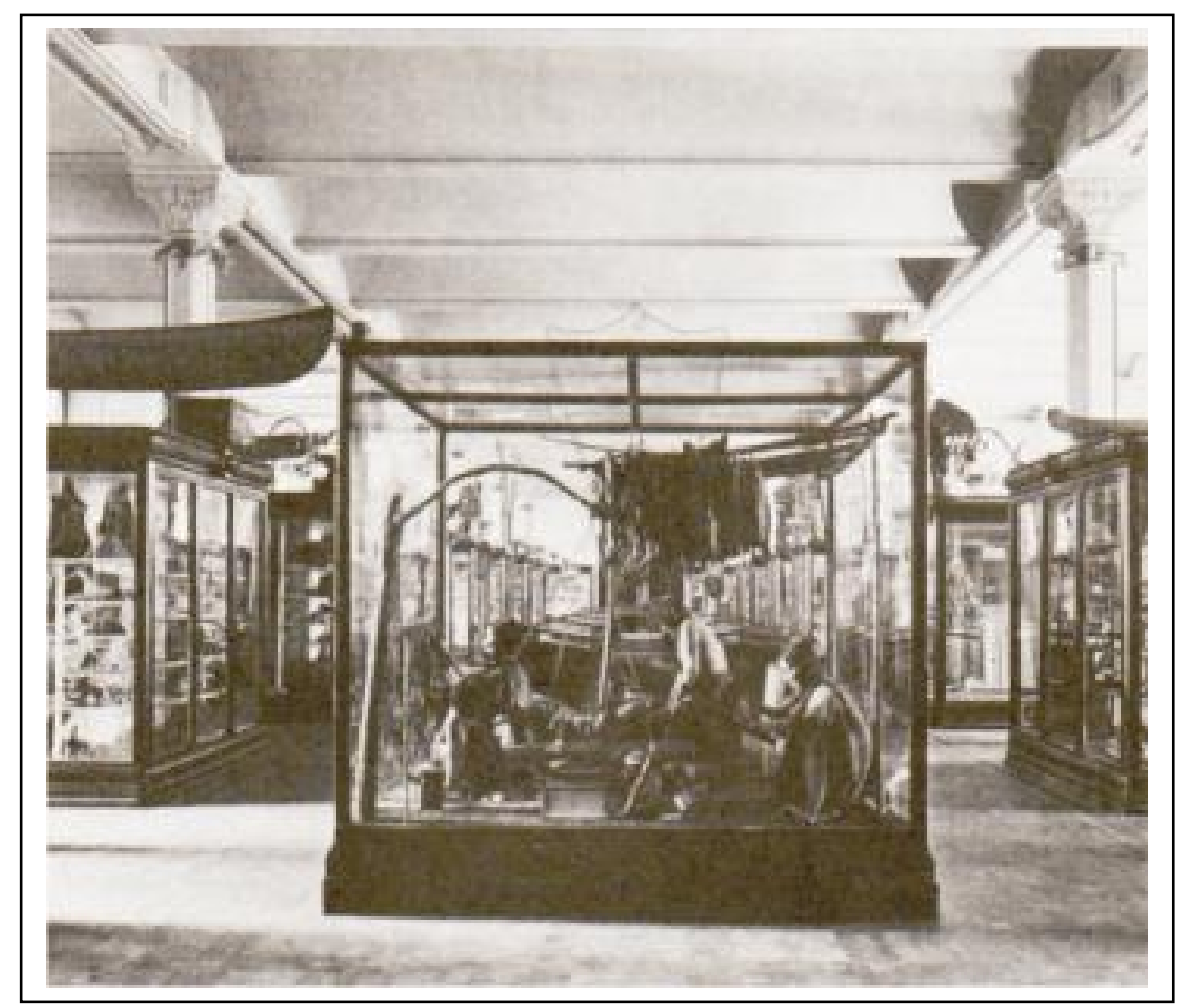

The Northwest Hall from the south, ca.1902

Fuente: Objects and Others. 1985

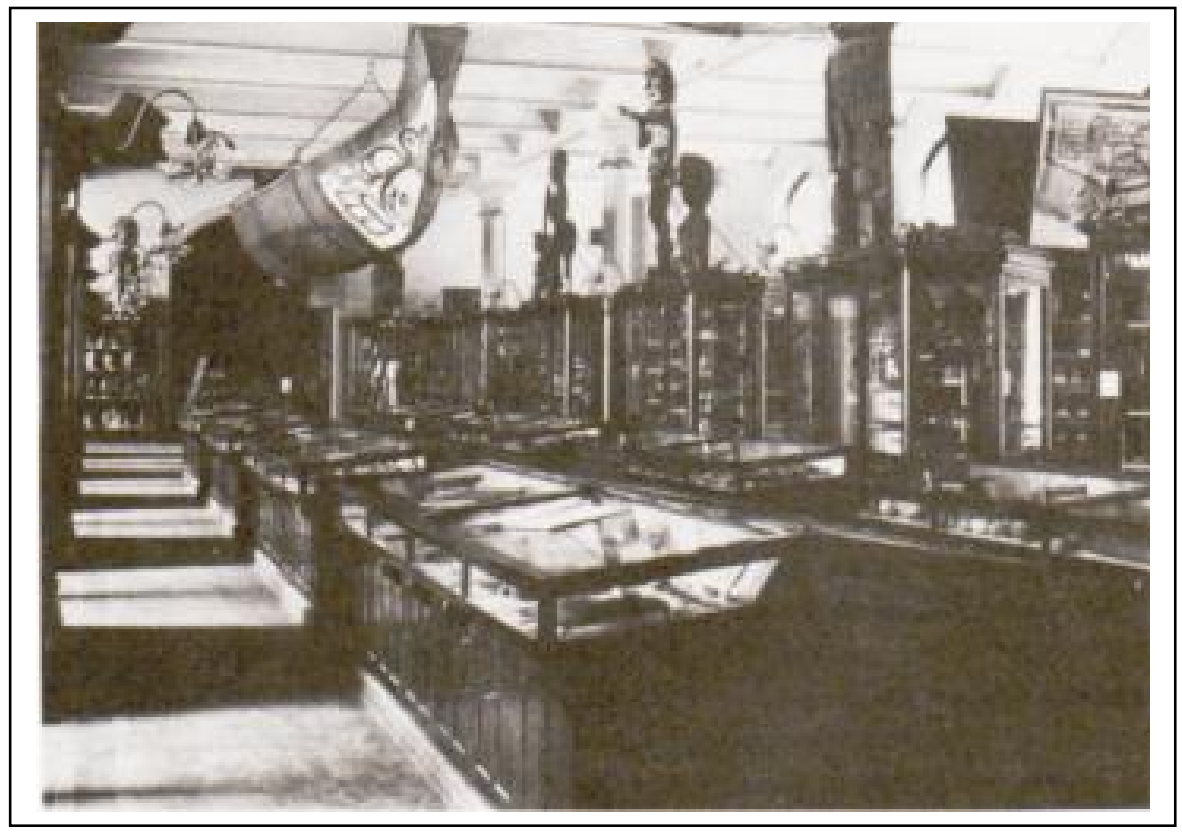

The Northwest Coast Hall, Northen end,

American Museum of Natural History. Ca. 1902

Fuente: Objects and Others. 1985. 


\section{I.5. El Museo de La Plata}

El Museo de La Plata es un exponente emblemático de las ideas que guiaron el nacimiento de los grandes museos de ciencias del siglo XIX. Fundado en 1884 abre sus puertas al público cuatro años más tarde, en noviembre de 1888, cuando la ciudad de La Plata apenas tenía seis años. El conjunto inicial de sus colecciones formaban parte del museo Antropológico y Arqueológico de Buenos Aires desde 1877.

$\mathrm{Su}$ concepción, plasmada tanto en los aspectos edilicios, segmentaciones disciplinarias, organización de su recorrido y formas expositivas, reproduce las características propias del museo decimonónico. Guiado por las ideas científicas sobre la evolución de la naturaleza, el óvalo del edificio reproduce a "la grandiosa evolución universal y en sus salas se desarrollarán, de acuerdo con esta teoría, todas las formas de vida nacidas paulatinamente de las combinaciones de las fuerzas naturales, desde los tiempos más lejanos que pueda investigar el hombre hasta el presente" (Riccardi, 1989:17). Al igual que muchos museos de Historia Natural de la época, tanto de Europa como de América, las colecciones antropológicas ocuparon el último escalón de este recorrido evolutivo. En palabras de Moreno: "El aro prolongado que representa el anillo biológico que principia en el misterio y termina con el hombre.” (Moreno, 1890:14).

Sus galerías y exhibiciones se organizaron según un recorrido que reflejaba la espiral evolutiva, desde el mundo inorgánico, hasta llegar, según diversos grados de complejidad creciente, al hombre. Catalogado como de Historia Natural, su guión conceptual respetaba con rigurosidad las ideas evolucionistas y positivistas del momento.

$\mathrm{Su}$ modelo expositivo respondía a las formas propias de los museos de fines del siglo XIX, principios del XX: vitrinas colmadas de piezas organizadas según clasificaciones taxonómicas y donde se podían apreciar los valores patrimoniales de la Nación. ${ }^{13}$

En 1906 el Museo de La Plata pasa a depender de la Universidad Nacional de La

\footnotetext{
13 “El visitante, luego del prólogo iconográfico del vestíbulo, iniciaba su recorrido en la sección geológica y mineralógica, pasando después por los restos fósiles de sucesivas edades terrestres para arribar, finalmente, en las salas dedicadas a la fauna actual de la República. En los patios interiores se exponía un relato paralelo sobre la evolución del "hombre fósil y moral, trama que comenzaba a la izquierda con una galería anatómica conteniendo cerca de mil cráneos y esqueletos de indígenas de América Austral, desde el hombre de la época glacial hasta el indico últimamente vencido" y seguía en el ala opuesta con los primeros pasos del hombre en la cultura ilustrados con piezas funerarias y de cultura material pampeanas y patagónicas. En el primer piso, ese recorrido cultural continuaba con pequeñas secciones dedicadas a las misiones jesuíticas y a la cerámica andina, a cuyos costados se encontraban, finalmente, la sección de bellas artes y la biblioteca, punto de llegada y cúpula de la evolución argentina." (Fernández Bravo y otros, 2003).
} 
Plata, creada en 1905. Es el momento en que Moreno deja la dirección y es reemplazado por el Dr. Samuel A. Lafone Quevedo, quien se desempeña en este cargo hasta 1920, momento en que es reemplazado por el Dr. Luis María Torres, hasta 1933. Este último, publica en el año 1927 la Guía para visitar el Museo de La Plata, la cual contiene con detalle la descripción de las colecciones, salas de exhibición y la departamentalización de las distintas áreas científicas. En los párrafos seleccionados y seguidamente transcriptos, referidos a las colecciones etnográficas, la disciplina y la sala, subyacen las concepciones evolucionista y positivista.

“Así podrá observarse toda la serie de fenómenos vitales y aún los medios en que se han desarrollado, pudiendo estudiarse desde origen tan remoto la marcha seguida por nuestra civilización hasta sus grandes conquistas actuales.

La historia universal nos enseña que las necesidades de los pueblos del presente, a cuyo impulso se realizan hazañas como la fundación de La Plata, concuerdan en el orden social con las primeras emigraciones y las humildes agrupaciones de seres inferiores, casi informes, en la infancia de la vida de nuestro globo; y es la historia de estos precursores -de los extinguidos, de los que aún viven y la de los fenómenos que los animan, -la de los medios en que actuaron o actúan, regido todo por las mismas leyes generales, la que contarán al visitante las colecciones expuestas en las galerías del Museo." (Torres, 1927:6).

"La etnografía es un disciplina concreta, que describe a los diversos pueblos indígenas; sus manifestaciones industriales, artísticas, la organización familiar y social pero sin propósitos de generalización. La etnología, a la vez, se propone el estudio sistematizado de todos esos caracteres, como de los tipos humanos, sus semejanzas y diferencias, dispersión geográfica en el pasado y presente, y trata de establecer verdaderas categorías, para las que tiene en cuenta los caracteres intelectuales, morales y sociales.” (Torres, 1927:262).

"Por otra parte, la evolución de los pueblos aborígenes no se presenta con los mismos caracteres en todos los casos, habiéndose realizado en desigual duración de tiempo; es decir, que unos han cumplido todo su proceso cultural y otros se han detenido en alguno de los estados de evolución primitiva sin llegar a cierto grado de perfeccionamiento.”(Torres, 1927:263). 
"Para ese entonces arqueología y etnografía formaban un único departamento. Los materiales arqueológicos estaban distribuidos en dos grandes salas: la primera de arqueología extra argentina y la segunda que reúne a lo que podemos llamar arqueología de nuestro territorio. (...) En la sala XXII se presenta todo el conjunto existente de valor etnográfico de la Argentina y el resto de América.” (Torres, 1927:266).

"En la sala XXII se exhiben sólo una parte de las colecciones de etnografía argentina y sudamericana. Los ejemplares que corresponden a los pueblos indígenas de otras partes del mundo, se guardan, debidamente conservados, en los depósitos y laboratorios del departamento. (...) en las grandes vitrinas, que son catorce, se distribuyen los objetos según un orden geográfico y etnográfico, seleccionando los ejemplares que pertenecen a la casi totalidad de los elementos del ajuar doméstico de los pueblos indígenas protohistóricos y modernos que figuran en nuestra exhibición. (...) en las recordadas grandes vitrinas como en las mesas y otras vitrinas laterales se distribuyen: objetos, instrumentos y armas de los grupos étnicos del Chaco, Misiones, Pampa, Patagonia, Chile, Bolivia, Paraguay, Brasil, Ecuador, Perú, etc.” (Torres, 1927:292).

Según Teruggi (1994) hasta 1984 en la historia del Museo de La Plata han sido reconocidas dos grandes épocas según el estilo expositivo. La primera abarca desde 1884 -1940 y la segunda hasta 1984.

En la primera etapa la forma de presentar las colecciones "era la de acumular en las salas la mayor cantidad posible de objetos, de modo que esos ambientes desempeñaban la doble función de lugar de exhibición y de sitio de depósito (...) El visitante quedaba abrumado por centenares y centenares de objetos en cada sala. (...) El Museo de La Plata siguió este modelo que era universal, y sus salas de exhibición se poblaron de vitrinas y estanterías atiborradas de materiales. (...) predominaba también la idea de que los museos debían ser en esencia "de especialista a especialista" por lo que era muy escasa o inexistente la información que se le daba al público.” (Teruggi, 1994:47).

"La segunda etapa incorpora tardíamente las innovaciones que en el mundo comenzaron entre los años veinte y treinta. Estas estaban de la mano de la incorporación de nuevas tecnologías (por ejemplo de iluminación) y formas de presentación más contextualizadas a través de incorporación de dioramas. Los cambios de actitud y mentalidad tuvieron que ver con cuestiones trascendentes: transformar al museo en un centro educativo para la ciudadanía." (Teruggi, 1994:70). 
Estas intervenciones aisladas modificaron parcialmente el guión global original del museo. Si bien se alude en esta revisión descriptiva a las formas expositivas, las innovaciones en esta área no aparecen expuestas en este análisis como el resultado de un debate científico sino como la expresión de una necesidad de innovación atendiendo al movimiento que se dio universalmente en los museos y a los requerimientos del público.

Originariamente los materiales de carácter etnográfico estaban expuestos junto con los materiales arqueológicos ${ }^{14}$, ambos incorporados a las colecciones de la división arqueología. En el año 1913 se separan la sección de arqueología y etnografía, quedando como jefe de esta última el Dr. Luis María Torres.

Hasta su renovación completa, motivo de este análisis, la sala etnografía había sufrido modificaciones parciales de algunas de sus vitrinas, pero que, sin embargo mantuvieron el eje de la exhibición centrado en el objeto. Cada vitrina constituía una unidad en cuyo interior los objetos se organizaban por procedencia geográfica, étnica o temática, sin que fuera posible establecer claramente relaciones entre ellas.

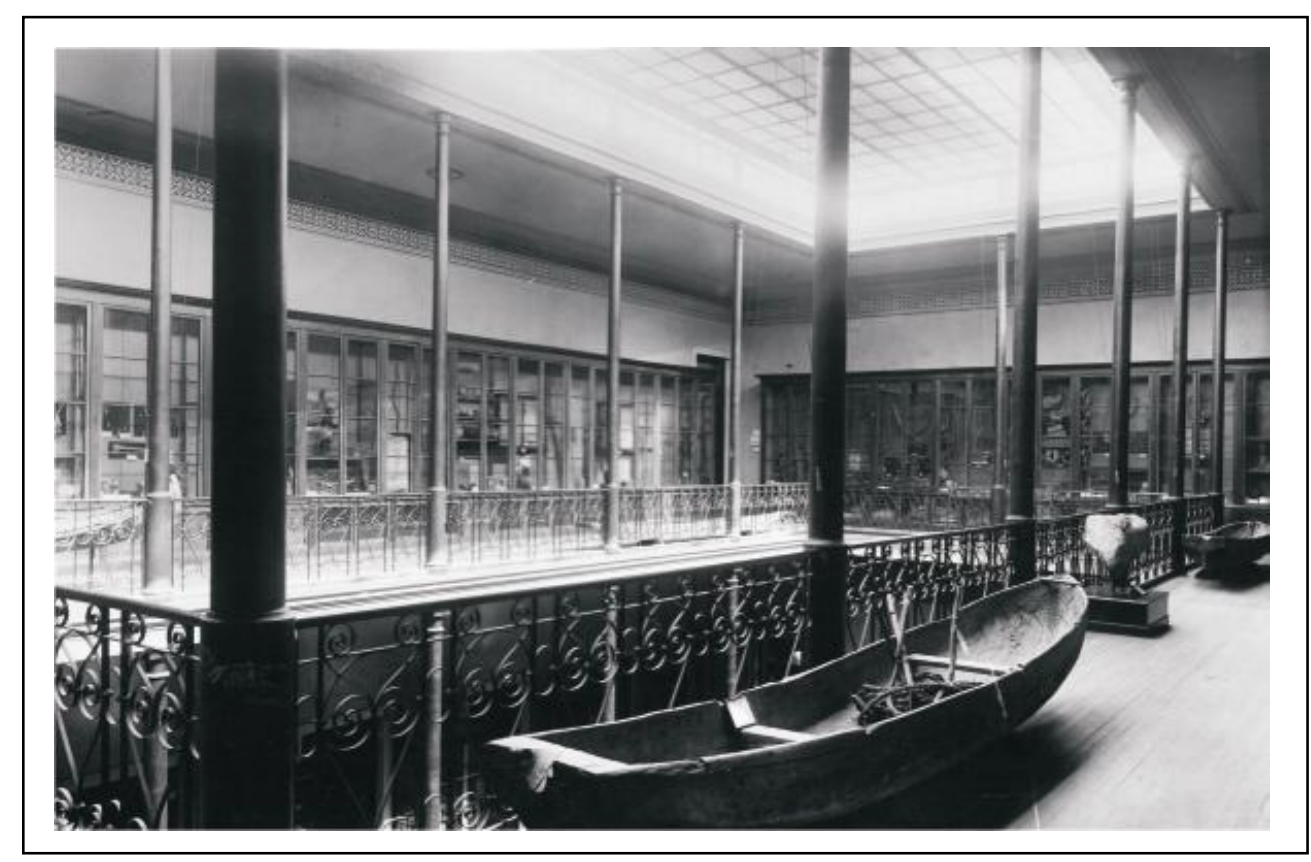

Departamento de Arqueología y Etnografía.

Sala de Etnografía Argentina y Sudamericana-Ca. 1920

Fuente: Torres, 1927

\footnotetext{
14 "El salón alto a la izquierda, situado sobre el que ocupa la antropología anatómica, contiene las colecciones de comparación arqueológicas y etnográficas antiguas y modernas, (...); también una serie etnográfica de Polinesia, y entre esta algunos objetos recogidos en Chile, indicando así antiguas emigraciones, piezas que son de la más grande importancia. Además, series etnográficas del gran Chaco, Patagonia y Tierra del Fuego, Bolivia, Paraguay y Brasil y una pequeña sección egipcia ocupan también esa sala." (Moreno, 1890:23).
} 


\section{Capítulo II}

\section{EL PROBLEMA DE LA RE-PRESENTACIÓN}

"Una idea puede ser signo de otra no sólo porque se puede establecer entre ellas un lazo de representación, sino porque esta representación puede representarse siempre en el interior de la idea que representa." (Michel Foucault, 1996) 


\section{Capítulo II: EL PROBLEMA DE LA RE-PRESENTACIÓN}

\section{II.1. Vigencia de un debate}

La problemática de la representación de otras identidades no se restringe al área de la exhibición, pues la preocupación por la autenticidad del conocimiento sobre otras culturas y la rigurosidad de su producción es un debate siempre vigente en la antropología. Desde sus inicios, los primeros etnógrafos que desarrollaron trabajos de campo intensivo hacen referencia a este punto vinculado a la discusión sobre el estatus científico de esta área de conocimiento.

En las últimas décadas, la teoría antropológica y la experiencia etnográfica son el foco de un renovado debate sobre la representación de la identidad en los museos aportando elementos para el análisis crítico. Sin duda la exhibición de colecciones es uno de los ámbitos de desarrollo de estrategias que dan cuenta de las diferentes prácticas y representaciones que, sustentadas por las ideas vigentes de cada época, consolidan, expresan y hacen visibles los distintos campos de conocimiento, al interior de los cuales se experimentan controversias teóricas, conflictos de intereses, encuentro de diferentes racionalidades, en definitiva, un área compleja de confrontación y tensiones.

El paralelismo planteado entre la antropología y los museos no es sólo porque desde sus orígenes el museo etnográfico ha ilustrado y conformado incluso las teorías etnológicas, sino porque en la actualidad las formas de representación museística se enfrentan a los mismos dilemas que los conceptos teóricos (Pazos, 1998).

El análisis histórico de las formas expositivas y su acompañamiento disciplinar deja ver que el problema de la representación ha sido motivo de controversias y debates respecto de qué, cómo y quién ejerce la autoridad para exhibir/representar.

La historia del pensamiento científico pone de manifiesto la transformación de los principios explicativos que estructuran las interpretaciones. La antropología no ha permanecido al margen de estos movimientos de ideas, que podríamos decir, tuvo su primera ruptura epistemológica en el pasaje del estudio de los fenómenos en sí mismos al estudio de las relaciones entre componentes, de una visión sistemática a una visión sistémica, tanto a nivel de los fenómenos conscientes como inconscientes. Esto trajo aparejado una diversidad de enfoques complementarios y contrapuestos que ampliaron 
profundamente las metodologías y formas de abordaje de los fenómenos sociales, pasados y presentes, sin perder de vista la perspectiva propia de la disciplina, "adueñada" del análisis de la diversidad de las manifestaciones culturales en tiempo y lugar. $^{15}$

Por otro lado, las reflexiones de orden teórico-metodológico han llevado al progresivo reconocimiento del grado de intervención del investigador en la producción del conocimiento de otras culturas, intervención que para el caso de la etnografía, se instala en la relación informante - antropólogo, los niveles de discurso y las categorías que estructuran la visión del mundo de cada grupo.

A partir de un concepto semiótico de cultura, Clifford Geertz define la tarea del etnógrafo como "descripción densa". Destaca el carácter interpretativo de la descripción reconociendo al etnógrafo como observador/intérprete que inscribe en el relato la vida social como jerarquías estratificadas de significación. Interpretación de segundo o tercer orden. La capacidad de "hacer presente" lo ausente, de evocar es parte de la eficacia del relato etnográfico. Se analiza la retórica de los autores clásicos cuyo fundamento es el “estar allí" (Geertz, 1978).

"La paradoja de la etnografía es que la "autoridad científica" viene dada por la experiencia subjetiva (ese trabajo de campo tan mitificado) y, a pesar de ello, durante años el antropólogo se ha sentido en la necesidad de relegar todo lo que "oliera a personal" a los anecdotarios y memorias marginales. Esta contradicción, considerada con detenimiento, es sólo aparente: el antropólogo procuraba, estilísticamente hablando, conferir un carácter o tono objetivos a su descripción, sabedor de que el "certificado de autenticidad" de la misma dependía de un acto de subjetividad." (Díaz Viana en prólogo de Clifford, 1991:13).

En el transcurso de los años 80 otros factores vienen a sumarse a esa renovación surgidos de la aparición de dos frentes de impugnación diferentes, aunque en cierto modo ligados: 1) la denuncia teórica de ciertos supuestos culturales de la antropología;

\footnotetext{
${ }^{15}$ El trabajo de campo etnográfico en la modalidad de observación participativa podría seguir siendo durante un tiempo la característica principal de la investigación antropológica, pero las circunstancias cambiantes de los otros que tradicionalmente han sido su sujeto objeto, y su cambiante relación con el mundo europeo, ya han cambiado el carácter del trabajo de campo y reducido su importancia relativa (Stoking, 1985). A lo cual debemos sumar la incorporación del estudio de la sociedad de pertenencia del antropólogo.
} 
2) la aparición de las comunidades como sujetos con intereses explícitos y decididos, que chocan con los intereses y formas museísticas tradicionales (Pazos, 1998).

Nuevas líneas de investigación y una renovada crítica al paradigma de la modernidad se suman a este momento de revitalización y revisión del lugar de los museos en la sociedad, no ya como repositorios estáticos y de la memoria sino como espacios de resignificación y construcción social, donde las confrontaciones y el debate comienzan a formar parte de su accionar institucional. En este marco, el análisis de la identidad cultural o, mejor dicho, la construcción de la otredad como eje de las exhibiciones sobre la identidad, se hace nuevamente eco de las reflexiones de la antropología, y la incorporación paulatina de quienes, siendo el motivo de las salas de exhibición han estado ausentes. Nos referimos, por un lado aquellas comunidades cuya representación históricamente ha estado mediatizada por interpretaciones de segundo y tercer orden. Por otro lado, al público receptor de la propuesta expositiva que forma parte del imaginario de los curadores y otros actores del museo. ${ }^{16}$

Esta revitalización del vínculo de la antropología y los museos se da en varios sentidos. Hacia adentro de la institución las reflexiones teóricas intentan canalizarse en el hacer museográfico, atendiendo a los procedimientos, la mirada interdisciplinaria, la innovación de recursos, entre otros. A su vez, la apertura hacia la incorporación y presencia activa de los grupos tradicionalmente excluidos define al museo como un nuevo terreno de observación y ejercicio de prácticas sociales. Concebidos como "zonas de contacto" la estructura organizativa del museo se vuelve una relación permanente histórica, política y moral (Clifford, 1999).

Otras líneas de investigación refieren a la historia del museo, de las colecciones y los coleccionistas, su funcionamiento administrativo y la evolución de las prácticas museales. La biografía de los coleccionistas deja ver hasta qué punto estos son erigidos en agentes sociales que transforman una materia caótica en un sistema de orden y de sentido. La toma de posesión de los objetos y la elaboración de conjuntos completos lleva al colector a proyectarse en el mundo social.

Otra línea de aproximación consiste en el estudio del objeto mismo y sus desplazamientos en el tiempo y en el espacio. El estudio del movimiento de los objetos de una persona a otra, de una cultura a otra, por la vía del intercambio, tanto al interior

\footnotetext{
${ }^{16}$ Ejemplos de renovaciones recientes de los museos de antropología de Canadá, Francia, EEUU.
} 
como al exterior del museo, ofrece la posibilidad de entender mejor la vida social de los objetos: los rituales de toma de posesión, las manipulaciones en las recontextualizaciones culturales y las transformaciones de sentido. Por último, el análisis del objeto en sus aspectos formales, su condición material, estética, social y simbólica. Sin duda, se trata, para todos los casos, de aproximaciones complementarias (Turgeon y Dibuc, 2002).

\section{II.2. La sospecha de lo que viene dado}

El debate modernidad-posmodernidad, puso en tela de juicio la autoridad etnográfica y el modo en que los antropólogos construyen el conocimiento de otras culturas. En su versión más extrema, la crítica redujo a la investigación etnográfica a la seducción ejercida en sus escritos por parte del antropólogo/ autor a un lector poco avispado de que dicho escrito era el reflejo de su estadía en el campo: el "estar allí". Esto trajo aparejado un desprestigio importante para la antropología en el concierto de las ciencias en general y sociales en particular. Reducir la descripción del mundo a la habilidad literaria del autor dejaba poco espacio a la reflexión teórica, filosófica y política propia de la disciplina antropológica. Así, la retórica se transforma en la herramienta discursiva de la etnografía y el cuestionamiento de la autoridad etnográfica, impacta sobre la autenticidad del conocimiento producido.

Esta posición reduccionista y escéptica respecto al modo de producción del conocimiento antropológico, dejó a la representación vacía de sentido. Quizá su efecto más positivo como contracara de la modernidad haya sido el de la movilización de sus cimientos, las reflexiones sobre lo preconstruido y la ineludible o innegable intervención del sujeto productor del conocimiento. ${ }^{17}$

Pero el fin de la modernidad, ampliamente debatido está atravesado además por el impacto de los medios de comunicación a gran escala. La profunda transformación que experimenta nuestra sociedad en las nociones de tiempo y espacio, el vértigo de la experiencia y la construcción de múltiples versiones del mundo (Guiddens, 2003). La

\footnotetext{
17 Otras versiones más moderadas vienen a ocupar los lugares de esta reflexión. La antropología interpretativa (Geertz), la sobremodernidad y la inversión de la mirada hacia la sociedad compleja (Auge), el constructivismo social (Berger y Lukmann, Bourdieu), el paradigma de complejidad (Morin), el paradigma emergente (Miguelez).
} 
amenaza homogeneizante de la globalización anticipada por los teóricos resultó en el resurgimiento de las identidades locales, la visibilidad de las minorías y conjuntamente la pluralidad de visiones del mundo, "dato" de la realidad que la antropología ya había incorporado desde el relativismo cultural.

"La crisis actual de la concepción unitaria de la historia, la consiguiente crisis de la idea de progreso, y el fin de la modernidad, no son sólo eventos determinados por transformaciones teóricas (...) en el plano de las ideas. Han ocurrido muchas más cosas y muy diferentes: los llamados pueblos "primitivos", colonizados por los europeos en nombre del recto derecho de la civilización "superior" y más evolucionada, se han revelado, volviendo problemática, de facto, una historia unitaria, centralizada. El ideal europeo de humanidad se ha ido desvelando como un ideal más entre otros, no necesariamente peores, que no puede, sin violencia, pretender erigirse en la verdadera esencia del hombre, de todo hombre.

Junto con el fin del imperialismo y el colonialismo, otro gran factor ha venido a resultar determinante para la disolución de la idea de historia y para el fin de la modernidad: se trata del advenimiento de la sociedad de la comunicación. (...) Esta explosión de los mass media viene acompañada de una pluralidad de miradas.” (...).

En este contexto G. Vattimo se pregunta: “¿Qué sentido tendría la libertad de información, o incluso la mera existencia de más de un canal de radio y televisión, en mundo en el que la norma fuera la reproducción exacta de la realidad, la perfecta objetividad y la total identificación del mapa con el territorio? De hecho la intensificación de las posibilidades de información sobre la realidad en sus más diversos aspectos vuelve cada vez menos concebible la idea misma de una realidad." (Vattimo, 1990: 81).

Realidad, para nosotros es, más bien el resultado del entrecruzarse, del “contaminarse" de las múltiples imágenes, interpretaciones y reconstrucciones que compiten entre sí, o que, de cualquier manera, sin coordinación central alguna distribuyen los mass media. ${ }^{18}$

18 "Filósofos nihilistas como Nietzche y Heidegger (pero también pragmáticos como Dewey o Wittgenstein), al mostrarnos que el ser no coincide necesariamente con lo que es estable, fijo y permanente, sino que tiene que ver más bien con el evento, el consenso, el diálogo y la interpretación, se esfuerzan por hacernos capaces de recibir esta experiencia de oscilación del mundo posmoderno como chance de un nuevo modo de ser (quizás, al fin) humano." (Vattimo, 1990:87). 
Cuestionada la realidad, por definición queda cuestionada su representación.

Marcus y Fischer (2002) recorren los lineamientos teóricos y metodológicos más estructurantes de la historia de la disciplina para hablarnos de un momento experimental de la antropología, y una crisis de la representatividad. Tal situación está referenciada en esa antropología fundante del siglo XIX, a esa antropología cuyo objeto de estudio estaba circunscripto a las sociedades exóticas, lejanas y sin historia que sentaron las bases del nacimiento de los museos. A esa antropología de corte realista que, acompañando el proyecto de la modernidad, aspiraba a la comprensión objetiva del mundo y la versión unitaria de la historia. ${ }^{19}$

Estos autores describen el momento actual de la antropología como un estado de experimentación y ensayos. Recuperando los aportes de los estudios clásicos de la etnografía y del trabajo de campo, encuentran en la reflexión metodológica y teórica de las experiencias particulares la posibilidad de sobrellevar un momento de "crisis de la representación".

"Lo que define el momento actual es, pues, el debilitamiento de visiones totalizadoras definidas que se impongan a comunidades científicas de hecho fragmentadas o de estilos paradigmáticos que organicen toda investigación. La autoridad de los estilos "gran teoría" parece momentáneamente suspendida a favor de una atenta consideración de cuestiones como la contextualidad, el sentido de la vida social para quienes la protagonizan y la explicación de las excepciones y la indeterminación en los fenómenos observados, en desmedro de las regularidades: cuestiones todas aquellas que tornan problemático lo que, según se daba por sentado, eran los hechos o las certidumbres en que se basaba la validez de los paradigmas." (Marcus y Fischer, 2002:29).

"En consecuencia, en muchos ámbitos, los debates teóricos más interesantes se han trasladado a nivel del método, a problemas de metodología y de interpretación, y a las formas discursivas de representación en uso por los pensadores sociales. Promovidos a preocupación fundamental de la reflexión teórica, los problemas de descripción se transforman en problemas de representación. Donde más vigorosamente han sido

\footnotetext{
19 "La crisis del pensamiento social, del pensamiento filosófico, del pensamiento científico de fines del siglo XIX y principios del siglo XX pone en cuestión la posibilidad de construir sistemas explicativos y omniabarcativos." (Casullo, 2004:151).
} 
exploradas estas cuestiones, en las teorías filosóficas y literarias de la interpretación; de ahí la importancia que estas cobran ahora como fuente de inspiración de la reflexión teórica y autocrítica en tantas disciplinas.” (Marcus y Fischer, 2002:30).

Esta instancia de interpretación, cualquiera sea el contexto relacional en que se construya, está siempre ligada a la mirada particular del sujeto observador. La objetividad queda suspendida, entre paréntesis, y anclada en el conjunto de procedimientos a partir de los cuales la percepción se traduce en observación/interpretación. El sujeto de la ciencia forma parte, está inmerso, en sus construcciones. "El investigador posee un estado mental, personal, particular, que contamina las interpretaciones que realiza acerca de sus hechos de observación. La interpretación de la realidad (...) la que podemos entender como una imagen consensuada de relativa estabilidad, producida por los individuos que integran la sociedad, la cual reglamenta el consenso. Hacer consciente tales contaminaciones permite ejercer cierto control del discurso.” (Lahitte, 1996:55).

Compartimos con I. Karp en que la presentación de los objetos de otras identidades implica un grado exquisito de conciencia de sí mismos de parte de los curadores con respecto a sus propios supuestos y a cómo organizan la presentación de otras culturas.

Todas las exhibiciones están inevitablemente organizadas en base a supuestos acerca de las intenciones de los productores de los objetos, las habilidades y calificaciones culturales de la audiencia, las pretensiones de autoridad sobre el tema que tenga la exhibición, y los juicios sobre el mérito estético o la autenticidad de los objetos o entornos exhibidos (Karp, 1991).

\section{II.3. La vuelta a los museos}

Muchas veces un visitante arriba a una sala calificada de etnográfica sin encontrar ningún indicio no sólo de la situación actual de los grupos que se exhiben sino tampoco acerca de la disciplina. Este estado de cosas no responde únicamente a la calidad expositiva de una muestra sino a la ausencia de una reflexión actualizada acerca del papel de las exhibiciones y de una etnografía cuyo objeto de estudio ya no se restringe como en sus orígenes a culturas aisladas y exóticas, ampliando sus fronteras disciplinarias e incorporando el punto de vista del antropólogo-observador. 
A pesar de las limitaciones que una exhibición tiene por naturaleza, ellas vienen siendo reformuladas en el marco de un nuevo paradigma, en donde los museos no son ya los depositarios de la "verdad" y donde cabe la incertidumbre y la multiplicidad de miradas, de manera que el visitante encuentre la cuña por donde proyectar su propia "visión del mundo". Las exhibiciones etnográficas son sólo una forma posible de recrear una porción fragmentada de la realidad bajo un conjunto de supuestos teóricos y epistemológicos y en las cuales se filtran las intenciones hacia el visitante por parte de los curadores. La explicitación de estos supuestos permite, en primer lugar, dar cuenta del recorrido y las elecciones curatoriales. Por otro lado, sin el conocimiento de estos supuestos no existe ninguna posibilidad de evaluación de su eficacia comunicativa y su misión educativa. La crisis de la representación aludida por Marcus y Fischer demanda, en este estado de cosas, la plena conciencia de la intervención de los diversos intérpretes que están inmersos en los distintos contextos discursivos. El primero de ellos, el del etnógrafo y el trabajo de campo; el segundo, el de los curadores y la sala de exhibición, entendida como el contexto privilegiado y explícito de re-presentación del conocimiento antropológico en el museo. Por último, un nuevo intérprete define el contexto de apropiación, el visitante. El pasaje de un contexto discursivo a otro es el lugar donde se define una ética de la representación, un lugar lleno de interferencias y ambigüedades donde se gesta la posibilidad de abrir un espacio de reflexión acerca de la relación "nosotros-otros".

Cuando los objetos pasan a formar parte de las colecciones de un museo, salen del circuito utilitario para ingresar en nuevos circuitos semióticos "Todo objeto visible encuentra un valor que reside en su capacidad de servir a la producción de otra cosa para la que ha sido consumido.” (Pomian, 1990:178).

El objeto etnográfico, se impregna de un conjunto de valores desde el contexto de recolección. ${ }^{20}$ Esta condición, en muchos casos ha restringido el estudio de

20 Ciertas clases de objetos han sido cambiadas de un contexto a otro. Pero hablando en términos generales, el museo etnográfico y el museo artístico han desarrollado modos fundamentales diferentes de clasificación.

Pero en términos generales el museo etnográfico y el museo artístico han desarrollado modos fundamentalmente diferentes de clasificación. En el primero, una escultura se expone junto con otros objetos de similar función, o en proximidad a objetos pertenecientes al mismo grupo cultural, incluyendo artefactos utilitarios (cucharas, cuencos, lanzas, etc.). Una máscara o estatua puede ser agrupada junto a objetos formalmente disímiles, explicada como parte de un complejo ritual o institucional. Los nombres de los escultores individuales son desconocidos, o suprimidos. En el museo de arte, una escultura es identificada como la creación de un individuo. Su ubicación en las prácticas culturales cotidianas (incluyendo el mercado) es irrelevante a su significado esencial. Mientras que en el museo etnográfico un 
colecciones a una adjudicación mecánica de sentido, que busca la adecuación entre el objeto y porciones de discurso etnográfico, dando como resultado un concepto reduccionista y estático de cultura y, en consecuencia, las exhibiciones depositan en el objeto en sí el poder evocativo acerca de la cultura, siempre con referencia al pasado. Por otro lado, el observador encargado de la reconstrucción de dichos contextos queda fuera de la secuencia analítica e implicado sólo en un proceso selectivo de "lo dicho" por otros. En este nivel de análisis, necesario y válido para la organización de un museo, la colección es pensada como un sistema cerrado, restringiendo las posibles interpretaciones y, con ella, sus potencialidades expositivas. Los valores aparecen como fijos y atrapados en la materia. Su interpretación adopta, entonces, un carácter reconstructivo que evoca, a través de la cultura material, a un sujeto ausente.

Una vez categorizado, el objeto etnográfico es motivo de una naturalización de sus atributos, olvidando los criterios que gestaron su inclusión en dichas categorías. Estas actúan, en consecuencia como preconceptos. "Estos "datos", que suelen confundirse con lo concreto mismo, son en realidad producto de una formidable abstracción -lo cual sucede invariablemente- puesto que lo dado siempre es construido." (Bourdieu, 1995:168).

"La abdicación empirista tiene en su favor todas las apariencias y todas las aprobaciones porque, al ahorrarse la construcción, deja al mundo social tal cual es, al orden establecido, las operaciones esenciales de la construcción científica, la elección del problema, la elaboración del concepto y categorías de análisis, y cumple así, aunque sea por omisión, una función básicamente conservadora, la de ratificar la doxa." (Bourdieu, 1995:182).

Esta reflexión crítica y relacional de las formas de construcción del conocimiento y su representación se ubica en la "tormenta" de las tensiones que generan las dicotomías nosotros/otros, pasado/presente, sujeto/objeto, particular/universal, local/global, entre otras.

Las exhibiciones trans-culturales presentan contrastes tan marcados entre lo que conocemos y lo que necesitamos conocer, que el desafío de reorganizar nuestro conocimiento se convierte en un aspecto de la experiencia de la exhibición. Este desafío

objeto es culturalmente o humanísticamente interesante, en el museo de arte es fundamentalmente bello y original (Clifford, 1985). 
puede experimentarse en su modalidad más fuerte en las exhibiciones trans-culturales, pero debería surgir en toda exhibición. Casi por definición el público no llega a las exhibiciones con todo el bagaje de recursos culturales necesario para comprenderlas, de otra manera, no tendría sentido exhibirlas. Los públicos tienen dos elecciones posibles: o bien definen su experiencia de la exhibición de manera que encaje en las categorías de conocimiento existentes, o bien reorganizan sus categorías para que ajusten mejor con su experiencia. En forma ideal, es el shock del no reconocimiento lo que permite al público elegir la última alternativa. El desafío para los creadores de exhibiciones es proporcionar dentro de las mismas los contextos y recursos que permitan a la audiencia elegir la reorganización de su conocimiento (Karp, 1991).

La musealización del objeto etnográfico implica una instancia de subjetivaciónobjetivación esencialmente creativa que, no pretende más que exponer las relaciones entre dominios que justifiquen su re-presentación. De este modo se experimenta un giro en la perspectiva de análisis que ya no concibe al objeto en sí como depositario de un valor patrimonial, sino que éste se inscribe en el conjunto de relaciones, atribuciones e interpretaciones que les adjudica el sujeto intérprete.

Todas las exhibiciones están inevitablemente organizadas en base a supuestos acerca de las intenciones de los productores de los objetos, las habilidades y calificaciones culturales de la audiencia, las pretensiones de autoridad sobre el tema que trate y los juicios sobre el mérito estético o la autenticidad de los objetos o entornos exhibidos. Cada exhibición de museo, cualquiera sea su tema explícito, inevitablemente toma componentes de las fuentes y supuestos culturales de las personas que la hacen. Se toma la decisión de enfatizar un elemento y quitar importancia a otros, de afirmar algunas verdades e ignorar otras. Los supuestos que subyacen a estas decisiones varían de acuerdo con la cultura y también a lo largo del tiempo, lugar y tipo de museo o exhibición (Lavine y Karp, 1991). ${ }^{21}$

\footnotetext{
21 ...lo que está en juego en las luchas por controlar objetos y modos de exhibirlos es la articulación de la identidad. Las exhibiciones representan la identidad, sea directamente, a través de afirmaciones, o indirectamente, por implicancia. Cuando hay "otros" culturales involucrados, las exhibiciones nos dicen quiénes somos y, lo que quizás sea más significativo, quiénes no somos. Las exhibiciones son escenarios privilegiados para presentar imágenes de uno mismo y del otro.

Desde este punto de vista los agentes más poderosos en la construcción de la identidad parecen ser no los productores de los objetos ni el público, sino los mismos constructores de la exhibición, quienes tienen el poder para mediar entre partes que no tendrán contacto directo (Kaine,2002).
} 
El museo, en cuanto que es representación de prácticas y formas de vida, no puede sino expresar la paradoja propia de toda teoría cultural (que es también de naturaleza representacional o expositiva): el interés por describir y mostrar de la manera más fidedigna y completa un modo de vida, en toda sus singularidad y complejidad, solo experimentará frustración de unas formas de representación que, como tales, simplifican, reducen o sesgan el carácter propio de las culturas. Es lo que revelan en toda su complejidad las paradojas de la "nueva museología." (Pazos, 1998:41). ${ }^{22}$

\section{II.4. Elementos para un análisis crítico}

En el marco de la "crisis de representación" anunciada por Marcus y Fishcer (2000) para la etnografía, surge la alternativa de una epistemología que incorpore la paradoja, la contradicción y la incertidumbre, irreductibles en toda explicación de la experiencia humana. "Ese parece ser el espíritu de las respuestas que se elaboran en las distintas disciplinas en lo que hemos descripto como una crisis contemporánea de la representación.” (Marcus y Fishcer, 2000:37).

Se proponen a continuación algunos ejes conceptuales para el análisis crítico promovido en este estudio, surgidos tanto de los intentos de superación de los viejos modelos museográficos de presentación etnográfica como de las reflexiones teóricas al interior de la disciplina antropológica. Estos pueden ser enunciados como:

- La occidentalización de las culturas: las exhibiciones tradicionales se presentan como un relato unívoco y cerrado en la que predominan categorías clasificatorias e interpretativas "occidentales". Se desdibuja la perspectiva del nativo.

- El reduccionismo esencialista: presencia de objetos fuera de contexto con referencias primarias acerca de sus usos. La identidad aparece como un núcleo inamovible de ser, parecer y sentir, desde donde se define la pertenencia.

- El estatismo cultural: agrega al esencialismo la ausencia de situaciones de hibridación, contactos interculturales, enfatizando una idea de cultura definida

\footnotetext{
22 "La crítica cultural contemporánea es típicamente caracterizada como una competencia entre dos tradiciones intelectuales: el gran canon del iluminismo europeo y sus expresiones modernistas, por un lado, el cual al decir de muchos debería ser derrocado debido a su etnocentrismo, y las críticas del posmodernismo, por el otro lado, las cuales son presentadas como los multidireccionales y liberadores vientos de cambio." (Pazos, 1998).
} 
como un conjunto de prácticas y valores fijos en el tiempo.

- La dilución de los sujetos productores: el anonimato cultural que prevalece en las exhibiciones de depósito, no hay interpretación, sólo una identificación de categoría utilitaria. Esta disociación entre materiales de la muestra y gente real sirve para distanciar aún más aquellos pueblos de los visitantes. Esto no es sólo distancia en tiempo o aspectos de las relaciones posibles, sino de la realidad, porque la falta de asociaciones humanas directas y palpables con lo que se ve en la muestra hace que todo lo exhibido sea verdaderamente anónimo (Nason, 1999).

- La ausencia de referencias al mundo contemporáneo: los indígenas están presentes casi siempre como elementos del pasado de la comunidad, elementos que ya no tienen importancia en la vida presente de la comunidad. La cultura indígena es vista como un relicto del pasado. Esta disociación entre el pasado y el presente de la comunidad desnaturaliza la realidad de una presencia continua de los indígenas por el simple expediente de negarla (Nason, 1999).

El siguiente esquema expresa el movimiento disciplinar propuesto y su impacto en la exhibición de colecciones etnográficas. No se pretende agotar el desarrollo histórico sino dar cuenta del cambio en una síntesis comparativa del momento inicial del trabajo de campo, las recolecciones y el surgimiento de los museos y los cambios conceptuales en la actualidad.

\begin{tabular}{|l|l|}
\hline $\begin{array}{l}\text { Paradigma de la ciencia moderna: } \\
\text { Relato unívoco - discurso oficial- } \\
\text { objetividad -simplicidad - control. }\end{array}$ & $\begin{array}{l}\text { Crisis de la modernidad: } \\
\text { Múltiples relatos y versiones. } \\
\text { Ciencia con sujeto/ objetivación de la } \\
\text { subjetividad. } \\
\text { Inclusión del antropólogo. } \\
\text { Complejidad / sistemas relacionales. }\end{array}$ \\
\hline $\begin{array}{l}\text { Etnografía clásica } \\
\text { Relatos descriptivos - comunidades lejanas, } \\
\text { Relación entre autenticidad y } \\
\text { representación. }\end{array}$ & $\begin{array}{l}\text { Etnografía interpretativa } \\
\text { Análisis del discurso social. } \\
\text { Ampliación de su objeto de estudio } \\
\text { Inversión de lo lejano. } \\
\text { Mundo globalizado/multicultural. } \\
\text { Revalorización de lo local y estudios de } \\
\text { memoria. }\end{array}$ \\
\hline
\end{tabular}




\begin{tabular}{|c|c|}
\hline $\begin{array}{l}\text { Colección/tipología } \\
\text { Recolección en el marco del colonialismo } \\
\text { expansionista. } \\
\text { Apropiación conflictiva. } \\
\text { La colección como sistema cerrado: } \\
\text { el objeto cosa. }\end{array}$ & $\begin{array}{l}\text { Colección } \\
\text { Construcción de diversos contextos de } \\
\text { significación. } \\
\text { La colección como un sistema abierto: } \\
\text { el objeto signo. }\end{array}$ \\
\hline $\begin{array}{l}\text { Visión del indígena } \\
\text { Exótico - inferior - diferente y homogéneo. } \\
\text { Sin historia. } \\
\text { La diferencia como marco de referencia. } \\
\text { Identidad esencialista. }\end{array}$ & $\begin{array}{l}\text { Visión del indígena } \\
\text { Inmerso en procesos de hibridación: diásporas, } \\
\text { contacto interétnico/interculturalidad. } \\
\text { Concepto dinámico de cultura. } \\
\text { Incorporación de perspectivas émicas y visión } \\
\text { del mundo. } \\
\text { Identidad como construcción social. }\end{array}$ \\
\hline $\begin{array}{l}\text { Presentación en museos } \\
\text { La prevalencia del objeto. } \\
\text { Cultura estática, simple. } \\
\text { Perspectiva reduccionista. } \\
\text { Fortalecimiento de la diferencia. } \\
\text { Organización tipológica. } \\
\text { Recreación de contextos particulares. }\end{array}$ & $\begin{array}{l}\text { Presentación en museos } \\
\text { Conciencia por parte de los curadores de los } \\
\text { diversos niveles de interpretación y su carácter } \\
\text { de mediador. } \\
\text { La arbitrariedad de la construcción. } \\
\text { Inclusión de su punto de vista en la } \\
\text { elaboración de la exhibición. } \\
\text { Incorporación de diversas semiosis. }\end{array}$ \\
\hline $\begin{array}{l}\text { El visitante } \\
\text { Pasivo. Incorporación lineal de un capital } \\
\text { científico. }\end{array}$ & $\begin{array}{l}\text { El visitante } \\
\text { Activo, proyección de su capital cultural. }\end{array}$ \\
\hline
\end{tabular}

\section{II.5. Hacia un nuevo modelo expositivo}

La evaluación en torno a las exhibiciones como espacio comunicacional y su función en el marco de la educación no formal ha promovido una intensa reflexión a partir de las experiencias de innovación que los museos han incorporado en las últimas décadas. ${ }^{23}$ Una serie de teorías nutren el campo disciplinar de la museología y abren nuevas vías de análisis y relaciones transdisciplinarias. Es indudable que necesitamos una teoría del conocimiento y del aprendizaje para entender el modo en que nuestros visitantes perciben, interpretan e incorporan la propuesta expositiva a su bagaje de

${ }^{23}$ El Museo de las Civilizaciones de Quai Branly (París), inaugurado en el 2006, es un ejemplo de redefinición de la vocación de la institución. Siguiendo el modelo generado por el Museo Canadiense de la Civilización de Gatineau, desarrolló nuevas prácticas a fin de romper con el evolucionismo. Emmanel Desveaux, director del proyecto, se propone desarrollar prácticas que rompan con el evolucionismo y nuevas perspectivas para la clasificación y exhibición de los objetos. Afirma claramente su preocupación por evitar las trampas de la ficción, así como a las del mercado, las cuestiones de las nuevas instituciones, simplemente no se pueden ignorar. 
conocimientos. Una teoría semiótica provee los elementos que permiten extraer del objeto/cosa el mundo de significaciones del que puede ser motivo, tanto en sus aspectos formales como en sus aspectos simbólicos. La teoría de la comunicación aporta el análisis de los aspectos multifacéticos de la codificación y decodificación de los mensajes, la retroalimentación, circuitos de transferencia, metas y eficacia comunicativa. Las teorías sistémicas en su carácter de metateoría modelan los resortes epistemológicos para una comprensión relacional del mundo.

En la bibliografía museológica se reconoce el inicio de este movimiento entre los años 70-80 y se ha dado en llamar nueva museología. ${ }^{24}$ Entre los factores que han contribuido al cambio se enuncian la apertura a incorporar especialistas de la comunicación, la reubicación de los objetos como elementos de la construcción de una historia y la realización de los estudios de visitantes ligando la exposición a la educación y la acción cultural (Bergeron, 2002).

No es despreciable la incorporación de las nuevas tecnologías de la comunicación que permitieron dar diversos grados de dinamismo a la estática sala del museo tradicional. ${ }^{25}$

"Históricamente se ha ido operando un cambio en la interpretación de los objetos, por un lado (de la mera valoración estética aislacionista a su consideración como signo de funciones culturales), y en la concepción del visitante, por otro (de destinatario pasivo del discurso expositivo a sujeto activo, parte integrante de la exposición misma) (García Blanco, 1994). Consecuentemente con estos cambios también se ha operado una transformación en la conceptualización de la exposición; se ha pasado de la mera exhibición de objetos (exposición contemplativa) a una forma de comunicación con características específicas (exposición interactiva)." (Pérez Santos, 2000:54).

\footnotetext{
${ }^{24}$ También denominada museología de las interacciones (Galindo Castro, 2004).

${ }^{25}$ Es interesante el llamado de atención que hace Lorenc Prat sobre los límites de la innovación y la tendencia a la espectacularidad: "Esto ha provocado un efecto progresivo, una escalada, en la espectacularización de muchas activaciones y restyling patrimoniales recientes, una confluencia con la lógica del mercado del ocio, y por tanto de la trivialización, que las acerca a los parques temáticos, a veces casi a los parques de atracciones, con una reducción extrema de la polisemia de los elementos, en ocasiones casi con una total pérdida de significado, primando la sensación, el juego, la gratificación inmediata y superficial por encima de la reflexión interactiva, apelando con frecuencia, paradójicamente, a la interactividad, así como a una confusión, no sé si por necesidades justificativas, entre didáctica y banalidad."(Prat, 2005).
} 
Así, los museos y particularmente las exposiciones se han constituido en espacios de reflexión. Sus propuestas se han vuelto más pretenciosas respecto del tipo e intensidad de impacto que pretenden provocar en el visitante, ampliando las formas de percepción e incluyendo en su discurso tanto la certeza como la duda, provocando intencionalmente una incertidumbre creativa.

El punto de partida de esta nueva perspectiva implica el análisis de la relación visitante-museo, y rompe con algunos preconceptos que básicamente le otorgaban a las exhibiciones el poder omnipotente de dar cuenta de una totalidad, y al visitante, la función lineal y pasiva de absorber esa totalidad.

Esta apertura hacia el abanico de interpretaciones posibles elimina la lectura por parte del visitante de un relato unívoco. Las nuevas estrategias comunicativas promueven en el visitante una actitud participativa y con ella un verdadero aprendizaje. A su vez, cada visitante se conecta de modo diferencial con la exhibición, su percepción es selectiva y maneja ciertos grados de libertad durante el recorrido, dentro del espacio reglado que es la exhibición.

La libertad aludida no debe desresponsabilizar a los curadores de los resultados de la exhibición. Por el contrario, hemos visto que no existen miradas ingenuas a la hora de acomodar, dar forma y contextualizar aquello que refiere a la identidad cultural.

El cuadro que sigue presenta de forma comparativa la caracterización de lo que llamamos modelo de museo tradicional ${ }^{26}$ y el modelo emergente o nueva museología. Esta síntesis de referencia considera para el análisis las relaciones que se establecen en cada modelo entre el objeto-colección, visitante y curador a través de los cuales es posible aproximarnos a una definición de la misión del museo, el concepto de aprendizaje y el paradigma científico que "legitima" sus exhibiciones.

\footnotetext{
${ }^{26}$ Aunque sus características responden en gran parte a los museos del siglo XIX, preferimos el término tradicional para evitar referencias temporales.
} 


\begin{tabular}{|l|l|}
\hline Museo tradicional & Nueva museología \\
\hline El objeto como punto de partida. & $\begin{array}{l}\text { La relación sujeto-objeto como punto de } \\
\text { partida. Énfasis en la idea. }\end{array}$ \\
\hline $\begin{array}{l}\text { La exhibición como expresión del conocimiento } \\
\text { "verdadero". }\end{array}$ & $\begin{array}{l}\text { La exhibición como una forma posible de } \\
\text { exponer ideas probables. }\end{array}$ \\
\hline $\begin{array}{l}\text { El objeto es el depositario de los mensajes. } \\
\text { El objeto "habla por sí solo". }\end{array}$ & $\begin{array}{l}\text { El contexto como la construcción de } \\
\text { mensajes. "El objeto como mediatizador". }\end{array}$ \\
\hline $\begin{array}{l}\text { Visitante pasivo. } \\
\text { "Contemplación". }\end{array}$ & $\begin{array}{l}\text { Visitante activo } \\
\text { "Participación-interacción”. }\end{array}$ \\
\hline $\begin{array}{l}\text { Aprendizaje en un marco conductista } \\
\text { "Estímulo-respuesta". }\end{array}$ & $\begin{array}{l}\text { Aprendizaje significativo. } \\
\text { "Proyección”. }\end{array}$ \\
\hline Énfasis en lo cuantitativo. & Énfasis en lo cualitativo. \\
\hline Organización taxonómica y cronológica. & Organización sistémica. \\
\hline Segmentación disciplinaria. & Inter-transdisciplinaridad. \\
\hline
\end{tabular}

En la primera columna se describen las formas expositivas de los museos de ciencias en las que el supuesto de base era que "el objeto habla por sí solo" y, en consecuencia, éste ostenta la capacidad de conectar, a través de su materialidad, al visitante observador con el mundo que representa. Este efecto es el que Bárbara Kirshenblatt-Gimblett (1991) denomina función metonímica, es decir, el objeto es una parte que se encuentra en relación contigua con respecto a un todo ausente, que puede o no ser recreado. Se acepta la naturaleza fragmentaria inherente del objeto. Así, el responsable curador de la exhibición no tiene más que acomodar un conjunto de objetos en el interior de una vitrina en la que prevalece un orden taxonómico y sistemático anclado muchas veces en la referencia espacio-temporal. A su vez, las vitrinas colmadas de piezas dan cuenta de un criterio cuantitativo, ligado al modelo positivista donde tiene mucho peso lo mensurable, las regularidades y se constituye como la base empírica de la evidencia.

En la segunda columna, contrariamente, cuando el objeto está ubicado dentro de un contexto, incorpora el problema de la interpretación. Estos son puestos en contexto por medio de largas etiquetas, cuadros y diagramas, comentarios dados a través de auriculares, 
programas audiovisuales explicativos, docentes que dirigen visitas guiadas, panfletos y catálogos, programas educativos, y conferencias y representaciones. Otra forma de contextualizarlos es por medio de otros objetos, a menudo en relación con una clasificación o arreglo esquemático de algún tipo, basado en tipología de forma o relaciones históricas propuestas y a veces incluso se extienden a las circunstancias de la excavación, colecta y conservación. Hay tantos contextos para un objeto como estrategias interpretativas (Kirshenblatt-Gimblett, 1991).

En el modelo emergente el visitante es el centro de atención en la elaboración de una propuesta expositiva. La traducción de un guión científico en un guión museológico y finalmente, museográfico, tiene como protagonista al público receptor. En esta nueva perspectiva cabe la duda, la incertidumbre y el conflicto, fracturas por donde se filtra la posibilidad de reflexionar, quebrando el discurso monolítico de un conocimiento acabado. Se proponen, fundamentalmente un vínculo más relacional en el que la proyección, hacia el mundo cotidiano del visitante promueven un aprendizaje significativo y participativo en términos intelectuales, emocionales y lúdicos.

En cuanto a los recursos museográficos se intenta ampliar el campo de percepciones y jerarquizar la información en niveles complementarios. Un mismo objeto puede ser motivo de variados temas y perspectivas según los mensajes propuestos y el contexto en que se lo incluya, es decir, el sistema relacional desde donde se otorga un sentido.

En relación a los tipos de aprendizaje el cuadro presenta dos posiciones extremas. Una asume que el aprendizaje consiste en el incremento en la asimilación de información, hechos y experiencias. Esta visión lidera una posición conductista; el aprendizaje es acumulativo, responde a pequeños estímulos y el saber resultante es la suma de estos pequeños pasos. La mente, en el marco de esta teoría, es una tabla raza y el saber nace de la experiencia. La postura opuesta formula que la mente construye un esquema y que el aprendizaje consiste en la selección y organización de la riqueza de las sensaciones que nos rodean. El museo sistemático o tradicional se basa en la creencia de que el contenido de un museo debería ser exhibido de manera que refleje la "verdadera" estructura del tema-materia, adaptando su contenido para facilitar la comprensión al visitante. El modelo opuesto argumenta que el espectador construye un 
conocimiento personal de la exhibición y el proceso de ganancia del conocimiento es, en sí, un acto constructivo. Es lo que se denomina museo constructivista (Hein, 1999).

Es en el laberinto argumental que se filtran las posibilidades del cambio, un ejercicio intelectual que supone una transposición de categorías, ya que las exhibiciones son el encuentro de actores con diferentes racionalidades. Las nuevas estrategias comunicativas buscan involucrar al visitante. A su vez, cada visitante se conecta de modo diferencial con la exhibición, su percepción es selectiva y maneja cierto grado de libertad durante el recorrido. Las implicancias de esta perspectiva residen en imponer o generar una forma expositiva que se abra a la pluralidad de los puntos de vista.

El nuevo modelo expositivo asume la diversidad de lecturas, la complejidad socio-demográfica del público, el aprendizaje de relaciones, el encuentro de diferentes saberes y racionalidades.

Toda exposición se gesta fiel a unas pocas ideas debatidas al interior de la institución entre curadores, científicos, diseñadores, entre otros y coherentes con el diseño político más o menos explícito de la institución. Fiel a su historia pero mirando hacia la innovación, abierto a la imaginación pero anclado en el conocimiento científico, consciente de las limitaciones estructurales de espacio, tiempo y recursos pero aspirando a una producción de calidad que ponga en valor al patrimonio en todas sus dimensiones, históricas, sociales, estéticas. Abierto a la incorporación de nuevas voces y miradas que garantice que en cada suceso que acontece al interior de la institución no se pierda de vista que el patrimonio es público, que el conocimiento es democrático, que la sociedad es multicultural. En síntesis, ubicar la visita al museo como una experiencia de la contemporaneidad.

\section{II.6. De cuerpo presente}

Los museos etnográficos son motivo de renovación y debate, producto de las reflexiones acerca de su misión. Además de los aportes que recientemente la antropología ha hecho acerca del conocimiento de la identidad cultural y las nuevas miradas desde la museología, dos son los factores que impactan fuertemente en su renovación. Por un lado, la participación de las comunidades que, reconocidas como descendientes de los pueblos originarios y que históricamente ocuparon las salas etnográficas, reclaman el ejercicio de un derecho sobre el patrimonio. Por otro lado, el 
reconocimiento de estas instituciones de la necesidad de conocer más a fondo a sus visitantes, para desarrollar propuestas actualizadas acordes a sus expectativas.

El museo era el límite entre el espacio exterior del campo, donde se obtuvo el conocimiento antropológico y el interior del museo, el sitio donde el conocimiento etnográfico se re-presenta. Hoy los museos tienden a constituirse en instituciones "foro", es decir, lugares de encuentro, reflexión y debate, tendientes a generar un campo de interacciones, aprendizajes mutuos y co-gestión.

Países como Estados Unidos, Canadá y Australia (Turgeon, 2002) son ejemplo del desarrollo de una política de inclusión y diálogo, incorporando nuevos actores sociales que encuentran en el museo un espacio propicio para preservar su memoria y activar dispositivos de construcción de identidad. Las experiencias son diversas y se centran en torno a temas como la restitución, particularmente de los restos humanos de ancestros y objetos de carácter ritual y/o sagrado como el ajuar, y la participación en la elaboración de los mensajes que, destinados al público general, dan cuenta de su historia y sus saberes. ${ }^{27}$

En los años recientes, el sesgo ideológico y sistemático de la apropiación occidental de las culturas del mundo, ha caído retrospectivamente bajo escrutinio crítico y se sugiere que la "autenticidad" cultural o artística tiene tanto que ver con un presente inventivo, como con un pasado con su objetivación, preservación y renacimiento. La definición de valor cultural es una cuestión de debate histórico y político.

J. Clifford (1999) relata la experiencia de cuatro exhibiciones ${ }^{28}$ donde da cuenta de la complejidad y diversidad de las posibles relaciones que se establecen entre el museo y las comunidades aborígenes. Calificadas según se de la reciprocidad, la impugnación o la explotación, éstas prácticas lo llevan al autor a definir el museo como zona de contacto: "Cuando se ve a los museos como zonas de contacto, su estructura organizadora como colección se vuelve una relación permanente histórica, política,

\footnotetext{
27 En Canadá se reunió un grupo de trabajo compuesto por miembros de la asamblea de Primeras Naciones (una asociación indígena nacional) y la Asociación canadiense de Museos. Se gestó un informe presentado en 1992 con medidas destinadas a incluir a los nativos en cada paso de la gestión de la colección y construir un nuevo museo con la participación de las comunidades nativas.

En Estados Unidos, las medidas legales tomaron la forma de la Native American Graves Ley de Protección y Repatriación (NAGPRA). Esta legislación dio a las comunidades indígenas el derecho a recuperar los restos humanos y objetos asociados de los museos estatales (Turgeon, 2002).

${ }^{28}$ Estos son: El Museo de Antropología de la Universidad de Columbia Británica, El Museo y Centro Cultural Kwagiulth de la costa oriental de la isla Vancuver, El Museo Real de Columbia Británica y el Centro Cultural U'mita de la isla Carmorant.
} 
moral: un juego de tira y afloja, un conjunto de intercambios cargado de poder." (Clifford, 1999:238).

Esta zona de contacto conserva un núcleo estable y una frontera flexible, el espacio de intercambio. "En la medida en que los museos entienden que interactúan con comunidades específicas a través de tales fronteras y que no se limitan simplemente a educar o edificar a un público, comienzan a intervenir, en forma consciente y a veces autocrítica, en historias de contacto. Hemos visto algunas de las formas en que las prácticas museológicas en cuanto a la recolección y exhibición adquieren otro aspecto, cuando se las considera en una perspectiva de contacto. Los centros se convierten en fronteras, cruzadas por los objetos y sus hacedores. Tales cruces nunca son libres y sin duda están bloqueados rutinariamente por los presupuestos y el control curatorial, por las definiciones restrictivas de arte y cultura, por la hostilidad y la incomprensión de la comunidad. Los ejemplos que he elegido hasta ahora sugieren modos de negociar más democráticamente esas fronteras, elección que refleja la orientación reformista de mi análisis."

Seguramente, hacer partícipe al público general de esta experiencia de contacto sea la alternativa de los museos para erigirse en instituciones que, inmersas en la complejidad de la sociedad actual, impacten sobre un ejercicio ciudadano de tolerancia y respeto. 


\title{
Capítulo III ESPACIOS, OBJETOS E INTÉRPRETES
}

\author{
"Si pensamos que el mundo es el lugar de la emergencia \\ de la significación para un sujeto humano que se ve \\ incluido en su interior y obligado a pronunciarse en torno \\ a su sentido, no costará mucho aceptar que cualquier \\ obra humana se convierte en potencial portadora de \\ significación por el mero hecho de su existencia." (Santos \\ Zunzunegui, 2003).
}




\section{Capítulo III: ESPACIOS, OB JETOS E INTÉRPRETES}

\section{III.1. La mirada semiótica y los contextos de significación}

Los objetos de colección, se trate de objetos de arte, arqueológicos, etnográficos o de otro tipo ${ }^{29}$ adquieren diversos sentidos según el sistema de referencia del que forman parte. A decir verdad, este postulado semántico impregna cualquier experiencia humana; nuestra facultad semiótica consiste, justamente en esta posibilidad/condición de adjudicación de sentido al mundo que nos rodea, incluyéndonos a nosotros mismos. Por definición, ninguna experiencia humana queda fuera del mundo de la significación o, mejor dicho, para esta operación siempre será necesaria la presencia de un sujeto. Pero los significados no están en la esencia de las cosas, no constituyen una condición material o espiritual que forma parte de la naturaleza inmanente de las cosas, sino que son el resultado de procesos cognitivos por los cuales percibimos, ordenamos, categorizamos, representamos e interpretamos el mundo.

El planteo semiótico fundamental consiste, en que “... los fenómenos que constituyen el mundo no se nos dan desde sí mismos, sino que nosotros los identificamos adecuándolos a nuestras posibilidades de designación; ni contienen en sí mismos su razón de ser, sino que la proyectamos nosotros en función de las categorías disponibles en nuestra estructura conceptual; ni tampoco son vistos (ni comprendidos) tal como son, sino como nuestra modalidad de enunciación nos hace verlos (o comprenderlos) en el entorno perceptual correspondiente.” (Magariños de Morentín, 2008:66).

Desde otra perspectiva, la antropología cognitiva se ocupa del análisis de los modos del conocer. Qué y cómo conocemos es el producto de una relación entre un sujeto y su entorno. El proceso de generación de información por parte de un sujeto perteneciente a una comunidad dada y en un momento particular, podrá dar cuenta, a posteriori, de dicho vínculo. "Si la información es la unidad mínima de idea, como sostiene Gregory Bateson (1991), la información es ecogénica por definición (...) la

\footnotetext{
${ }^{29}$ Clifford distingue los objetos etnográficos (artefactos) y los objetos de arte (estéticos). Esta separación no ha sido impermeable y ciertos objetos han cambiado de una clase a otra. En términos generales, el museo etnográfico y el museo artístico han desarrollado modos fundamentalmente diferentes de clasificación. En el primero una escultura se expone junto con otros objetos de similar función, o en proximidad a objetos pertenecientes al mismo grupo cultural, incluyendo artefactos utilitarios, en el marco de una práctica cotidiana. Además, los nombres de los escultores, por ejemplo en el caso de una máscara, son desconocidos. (Clifford, 1985) En el recorrido de esta tesis nos aproximaremos a una definición de objeto etnográfico de carácter contextual y semiótica.
} 
idea, según este razonamiento, es el producto emergente de actos de distinción que ejecuta el observador en su entorno. Esa visión de la idea justifica, a posteriori la consideración del vínculo observador-entorno" (Lahitte, 1995:31). Esto es válido para cualquier experiencia cognitiva. ${ }^{30}$

Ahora bien, si el sujeto al cual nos referimos se enmarca dentro de lo que se concibe como dominio científico, es que podemos hablar de una epistemología relacional. Bajo ciertas exigencias, este "sujeto de la ciencia" deberá dar cuenta y hacer explícitos el conjunto de procedimientos por los cuales se transforma la información perceptual en conocimiento demostrable. En otras palabras, explicitar el conjunto de operaciones analíticas, que permiten reformular con carácter explicativo la experiencia de observación (Lahitte, 1989).

La explicación de la significación tendrá que partir del modo en que el ser humano expresa cómo ese fenómeno ha entrado en su mundo de experiencia. Lo expresa enunciándolo y entra en su mundo interpretando los enunciados (pan-semióticos) de su aprendizaje. El enunciado que él produce y los enunciados aprendidos constituye el corpus necesario para fundamentar cualquier investigación que pretenda explicar el significado atribuido a los fenómenos de su entorno (Magariños de Morentín, 2008).

Partimos de la idea de que cuando los objetos pasan a formar parte de las colecciones de un museo, salen del circuito utilitario para ingresar en nuevos ámbitos semióticos. Como expresa K. Pomian (1990) todo objeto visible encuentra un valor que reside en su capacidad de servir a la producción de algún sentido diferente de aquel por el cual ha sido construido o consumido. Es decir que, el conjunto de significaciones de las que será embestido un objeto de colección depende de la entramada red de relaciones semióticas (icónicas, simbólicas e indiciales) establecidas en algún contexto particular, para cierto intérprete en el marco de una comunidad dada.

\footnotetext{
30 “La mente, en términos de Bateson (1981) no es un fenómeno interior al organismo-sujeto, los límites del sistema ecomental para este autor sobrepasa los límites biológicos del organismo. (...) E 1 valor de la obra de Bateson reside en sacar la mente de sus envolturas corpóreas, para corporizarla en los múltiples canales de comunicación interorganísmicos. La mente constituye un sistema de comunicación cuyo contexto está delimitado por su propio operar, por su funcionamiento, a través de vías y circuitos en los cuales es posible generar información a partir de la experiencia.

Esa información emerge de la extracción de diferencias, de los actos de distinción del organismo sujeto inmerso en el sistema ecomental. El sujeto de la acción corporiza la mente a través de sus productos, las ideas que emergen de la relación como registros de la experiencia vivida (mensajes, datos, esquemas de acción)." (Lahitte, 1995:55).
} 
Desde aquí es posible asumir un concepto dinámico de patrimonio. Los valores adjudicados a un bien patrimonial son recreados por diferentes intérpretes (en instancias individuales y colectivas). "El patrimonio surge cuando una comunidad cultural le da forma a esos lazos de conectividad y pertenencia, otorgándole calidad de representación a los bienes tangibles e intangibles que elige valorar. Hace visibles esos lazos creando constantemente significados que se plasman en danzas, cantos, esculturas o arquitecturas y tantas otras formas creativas. Hay que reconocer, por tanto, que el patrimonio se halla en constante redefinición y movimiento. Dicho de otra manera, lo que mantiene en vida el patrimonio es que los individuos de la comunidad cultural recuerden y recreen su significado en cada período histórico.” (Arizpe y Nalda, 2002:210).

En esta tesis el tema se centra en el análisis de la significación asignada a los bienes culturales de carácter etnográfico en el marco de la institución museo. Para esto se identifican al menos tres contextos a partir de los cuales los objetos etnográficos adoptan sentido para determinados intérpretes. A su vez, esa interpretación se materializa/expresa por medio de las formas de semiosis icónicas, indiciales y simbólicas, que caracterizarán, los distintos corpus de análisis.

El criterio de delimitación de cada uno de los contextos se relaciona con tres dominios de conocimiento: el de las colecciones etnográficas, el de la exhibición de dichas colecciones y el de la interpretación por parte de los visitantes. Denominaremos a cada uno de estos dominios como el contexto de recolección, el contexto de representación y el contexto de apropiación respectivamente.

En cada uno de ellos es necesario identificar los referentes, los intérpretes y las relaciones de producción de sentido. Los preceptos de la epistemología relacional, la semiótica y la teoría de la comunicación estarán referenciados en la experiencia del observador-visitante en la sala de exhibición. La identificación de estos tres contextos permitirá, luego, establecer las relaciones inter-textuales e indagar acerca de la condición de re-presentación de las salas de exhibición.

\section{III.2. El acto de adjudicación de sentido es siempre una interpretación}

El mundo natural aparece como una magnitud macrosemiótica donde la significación se muestra a la vez omnipresente y multiforme. 
Esta magnitud se articula con la macrosemiótica de las lenguas naturales y puede ser entendida como el campo de ejercicio de variadas prácticas a través del recorte en su interior de toda una serie de discursos.

Pero estos discursos no pueden ser considerados entidades existentes "a priori”, sino que son construidos mediante una operación de pertinentización, que es la que pone de manifiesto en su operatividad, la existencia de variados conjuntos significantes estructurados y susceptibles de análisis (Zunzunegui, 2003).

Si bien, con un criterio analítico, es posible distinguir las distintas semióticas intervinientes en la producción de sentido, existe un único nivel de representación mental, la estructura conceptual, en la cual la información lingüística, sensorial y motriz es compatible.

Este enunciado teórico es lo que Magariños de Morentín, citando a Jackendorf, denomina la Hipótesis intersemiótica: "Existe un único nivel de representación mental, la estructura conceptual inter-semiótica, en el cual las representaciones icónica, indicial y/o simbólica de la información linguística, sensorial y motriz son compatibles, lo que permite la producción de la interpretación.” (Magariños de Morentin, 2008:58).

Este enunciado funciona a la vez como un principio explicativo del análisis, en el sentido en que es necesario identificar los rasgos y las relaciones de esta estructura en un tiempo y lugar determinado para una comunidad dada. En este trabajo, delimitado por la experiencia situada provocada por la visita a la sala de exhibición.

“O sea, si se han identificado los rasgos más elementales de esta estructura conceptual intersemiótica, junto con el proceso de las relaciones inter-semióticas que la generan, es posible instrumentalizarlos para dar respuesta a un problema determinado, en un momento y lugar determinado, acerca de la confluencia e interactividad de los textos (de cualquiera materias primas semióticas) que produjeron cada una de las significaciones vigentes atribuidas a determinado fenómeno social. Es preciso, tan sólo, haber investigado o investigar ambos aspectos, el que establece el procesamiento semiótico mínimo de representación y transposición (o transducción) aplicado a la información que acerca de dicho fenómeno se recibe, como condición necesaria para su almacenamiento, y el que hace a la arquitectura semiótica mínima que configura el almacenamiento de dicha información como condición necesaria para su contraste y disponibilidad.” (Magariños de Morentin, 2008:58). 
Esa información emerge de la extracción de diferencias, de los actos de distinción del organismo sujeto inmerso en el sistema ecomental. El sujeto de la acción corporiza la mente a través de sus productos, las ideas que emergen de la relación como registros de la experiencia vivida (mensajes, datos, esquemas de acción). Es imperioso, que se hagan explícitas y se comprendan las bases epistemológicas que subyacen a todas nuestras pautas de conducta, nuestras acciones, nuestras percepciones y nuestras reflexiones y conceptualizaciones acerca de la experiencia (Lahitte, 1996). ${ }^{31}$

La referencialidad es, entonces una condición del proceso de interpretación. La aproximación cognitiva se ocupa de las configuraciones del pensamiento sobre la base de construcciones, e interpretaciones, igualmente posibles, de las cuales algunas de ellas logran realización (Lahitte, 1996).

"Interpretar un fenómeno social constituye en principio, un acto de atribución de sentido y no de captación de algún (im)posible sentido original, natural o esencial; en un segundo momento, el conjunto de los sentidos construidos mediante las interpretaciones comunicadas que hemos podido percibir constituye la significación que le atribuimos. (...) Significación es el conjunto de todos los sentidos vigentes en determinada comunidad a determinado fenómeno.” (Magariños de Morentín, 2008:67). Dicho de otro modo, interpretar un fenómeno no puede ocurrir sin la intervención de un sujeto; la interpretación interesa en la medida que se exterioriza al comunicarse (o sea, trabajamos sobre interpretaciones explícitas) mediante un texto verbal o cualquiera de las modalidades comunicativas no verbales, gestual, espacial, gráfica, etc. En síntesis, el acto mismo de adjudicación de sentido se encuentra circunstancialmente situado en una experiencia referencial concreta y materializado en la enunciación, cualquiera sea el tipo de código en que se inscribe.

\footnotetext{
${ }^{31}$ En cada sociedad los individuos co-construyen la idea de realidad en el propio compartir de las experiencias personales. Esta idea nuevamente, explicita el consenso en cuanto al universo de significación $\mathrm{y}$, también, en cuanto a la responsabilidad de las acciones. (...) La palabra cognición necesita ser explicitada (...) en sentido figurado significa aquello que es configurado, aquello que cocontruimos. Los conocimientos se organizan y estructuran o, en términos de Denis (1984), se definen funciones referenciales y funciones elaboradas que permiten la formación de las imágenes. (...) sin embargo, debe quedar en claro que nosotros no somos conscientes del proceso por el cual estas imágenes se forman. Sabemos que formamos imágenes, sabemos qué imágenes formamos, pero no sabemos cómo. Las imágenes siempre son retrospectivas (Lahitte, 1996).
} 
En consecuencia, el corpus de análisis estará constituido por el conjunto de propuestas perceptuales (discursos verbales, imágenes visuales, comportamientos, etc.) que le confieren calidad ontológica al fenómeno en estudio. Lo que podemos obtener (en este análisis) son los modos de atribuirle existencia, siendo las formas de existencia atribuidas las que constituyen su significación.

La unidad de análisis es el discurso, entendido como un todo de significación, tanto en el dominio de la sala de exhibición (para nosotros el contexto de representación) como en el dominio del estudio del visitante (el contexto de apropiación). El discurso es, entonces, una unidad compleja que abarca aspectos lingüísticos o simbólicos, icónicos e indiciales, de manera que la significación emerge en su articulación. A su vez, esta significación no es unívocamente interpretada por el visitante, no es nunca un espacio significante completo, acabado y definitivo, es el sustrato para configurar en el infinito juego de relaciones posibles, aquellas que, en concordancia con la estructura cognitiva del intérprete, resulta ser la expresión de los mundos semióticos posibles.

Definitivamente cierto grado de certeza nos permite interactuar con el mundo, pero el ejercicio reflexivo propuesto en este trabajo es el de la indagación acerca de los mecanismos por los cuales adjudicamos un significado a cierto fenómeno en un momento determinado y bajo ciertas condiciones de producción.

La delimitación de estos dominios no debe ser concebido como un corte definitivo ni verdadero. Como expresa Foucault, el análisis de los acontecimientos discursivos es una aproximación en la cual es posible reconocer relaciones de enunciación: "El análisis del campo discursivo (...) trata de captar el enunciado con la estrechez y la singularidad de su acontecer; de determinar las condiciones de su existencia, de fijar sus límites de la manera más exacta, de establecer sus correlaciones con los otros enunciados que pueden tener vínculos con él, de mostrar qué otras formas de enunciación excluye.”(Foucault, 2005:36).

A su vez, estos enunciados podrán agruparse en la medida en que se refieren a un mismo objeto, el cual, no se fundamenta en su existencia material y objetiva sino en el conjunto de reglas que hacen posible, durante un tiempo dado, su aparición como objeto. El discurso museológico acerca de la representación del conocimiento etnográfico de otras culturas responde, en distintos momentos, a formas particulares de 
entender la configuración de las colecciones, su distribución en el espacio expositivo, la disposición de los objetos al interior de la vitrina, su articulación con otros recursos que acompañan su puesta en escena, tanto como las ideas vigentes sobre el otro cultural, la intención de los curadores hacia los visitantes, la concepción acerca de los modos de apropiación del conocimiento, el diseño de una política institucional, el momento histórico en que se gesta, y las condiciones materiales de su producción.

Pero este conjunto de enunciados no constituyen un corpus homogéneo, sino que se presenta como relaciones dinámicas de coexistencia que muestran la dispersión, el reemplazo, la sustitución, la diversidad.

Nuestros hábitos cognitivos se aferran más a las regularidades, lo homogéneo, las repeticiones. Pareciera que la búsqueda de las certezas se instalara en el conocimiento de la regla y la ley como expresión de aquello que, naturalizado académicamente, se rodea del sentimiento de aceptación.

En tal sentido, Pierre Bourdieu, en su análisis crítico al empirismo, propone para la ciencia el ejercicio reflexivo de la ruptura con lo pre-construido, aquello que viene dado y se nos presenta como incuestionable. Para esto, entre otros argumentos enuncia que los (...) "datos, que suelen confundirse con lo concreto mismo, son en realidad producto de una formidable abstracción -lo cual sucede invariablemente, puesto que lo dado siempre es construido-..." (...) la construcción del objeto (...) no es algo que se lleva a cabo de una vez por todas, mediante una suerte de acto teórico inaugural, y el programa de análisis u observaciones a través del cual se efectúa dicha construcción no es un plan elaborado de antemano, como el de un ingeniero: se trata de un trabajo de larga duración, que se realiza poco a poco, mediante retoques sucesivos y toda una serie de correcciones y rectificaciones dictadas por lo que llamamos la experiencia, es decir, ese conjunto de principios prácticos que orientan las elecciones minúsculas $\mathrm{y}$, sin embargo, decisivas.” (Bourdieu, 1995:70).

"El significado resulta ser la compleja red de relaciones que pueden identificarse entre los diversos (todos, en la medida en que puedan ser recuperados) sentidos efectivamente vigentes en determinada comunidad; o sea, el conjunto de todas las interpretaciones explícitas que recibe el fenómeno en estudio, que es a lo que también puede denominarse el mundo semiótico posible construido acerca de tal fenómeno." 
(Magariños de Morentin, 2008:69). ${ }^{32}$

Como expresa Foucault, "en lugar de reconstituir cadenas de inferencia (como se hace a menudo en la historia de la ciencia o la filosofia), en lugar de establecer tablas de diferencias (como lo hacen los lingüistas), describiría sistemas de dispersión” (...) y continúa, "En el caso que se pudiera describir, entre cierto número de enunciados, semejante sistema de dispersión, en el caso de que entre los objetos, los tipos de enunciación, los conceptos, las elecciones temáticas, se pudiera definir una regularidad (un orden, correlaciones, posiciones en funcionamientos, transformaciones), se diría, por convención, que se trata de una formación discursiva, evitando así palabras demasiado preñadas de condiciones y de consecuencias, inadecuadas por lo demás para designar semejante dispersión, como "ciencia", o "ideología", o "teoría", o "dominio de objetividad"." (Foucault, 2005:62).

La realidad es, entonces, el resultado de una co-construcción, es el sistema relacional, a veces concebido como modelo -con carácter provisorio-, producto de la objetivación del sujeto objetivante.

\section{III.3. EI átomo de sentido desde Peirce}

Para Peirce representar es "estar en lugar de otro, es decir, estar en tal relación con otro que, para ciertos propósitos, se sea tratado por ciertas mentes como si se fuera ese otro" (1986:43). En el signo recae la concreción de esta relación.

Todo signo está constituido por tres componentes: el representamen, el interpretante y el objeto.

\footnotetext{
32 “....considero sentido a determinada y puntual interpretación explícita de un fenómeno, según resulta construida a partir de determinada propuesta perceptual (texto, icono, exhibición, ritual) que a tal fenómeno se refiera. Un mismo fenómeno adquirirá por tanto distintos sentidos, cada uno proveniente de cada una de las semiosis sustituyentes que lo construyan. Una de las tareas analíticas de toda investigación consistirá, por tanto, en identificar los diferentes sentidos vigentes en determinada comunidad acerca de determinado fenómeno. ... Al conjunto de los diferentes sentidos, relativos a un mismo fenómeno y vigentes en un momento determinado de una comunidad determinada, lo incluyo en el concepto de significado, que queda así constituido como el mundo semiótico posible de la totalidad de las interpretaciones explícitas que recibe determinado fenómeno en estudio (el concepto de mundo semiótico posible es próximo al de formación discursiva de Foucault, sólo que éste lo limita a una arquitectura constituida exclusivamente por enunciados verbales, mientras que el MSP abarca todas las semiosis posibles efectivamente utilizadas en determinada sociedad.” (Magariños de Morentín, 2008:69).
} 
El representamen o representación de algo, es el signo como elemento inicial de toda semiosis. Casi siempre es fruto del artificio o de la arbitrariedad de quienes lo crean, como sucede con las lenguas. Se define siempre "por alguna relación”.

El interpretante es la captación del significado en relación con su significante; en definitiva el interpretante es siempre otro signo y por tanto, algo le agrega al objeto del primero- y como dentro del modelo triádico la gestación semiósica es continua, el interpretante puede estar constituido por un desarrollo de uno o más signos. La noción de interpretante encuadra perfectamente con la actividad mental del ser humano, donde todo pensamiento no es sino la representación de otro: el significado de una representación no puede ser sino otra "representación". El signo tendrá éste carácter, siempre será "para alguien".

El objeto o fundamento es aquello a lo que alude el representamen, es decir, el signo siempre será "por algo".

A partir de esta constitución triádica del signo es posible comprender la estructura lógica mínima presente en la unidad de sentido. Cada uno de estos elementos y sus relaciones son indispensables para hablar de sentido. ${ }^{33} \mathrm{El}$ signo, que se hace presente mediante el representamen, aparece como producto de la interdependencia del interpretante y el fundamento.

Mediante el primer elemento (objeto), el signo captará lo que de conocimiento (fundamento) le interesa del objeto; mediante el segundo (representamen) se instituirá a sí mismo como forma perceptual y soporte sustitutivo de tal intervención y, mediante el tercero (interpretante) proporcionará la posibilidad de modificación que, en un determinado sistema, afecta al conocimiento o desconocimiento (pero no, noconocimiento) acerca de dicho objeto. ${ }^{34}$

\footnotetext{
${ }^{33}$ La incorporación del intérprete hace la diferencia con las propuestas estructuralistas que definen al signo como una unidad de dos caras, de naturaleza psíquica, el significante y el significado. Los estudios estructuralistas buscan describir la estructura interna del lenguaje (icónico, simbólico o indicial) independientemente del contenido semántico del mensaje y de su eficacia comunicativa. El interés se centra en el análisis del sistema de la lengua como conjunto inconsciente de reglas que permiten a cualquier individuo ser un buen hablante de su lengua materna. Estos estudios formales dejan de lado la circunstancia particular en la que se da la situación comunicativa, abandonando así el nivel de la pragmática.

34 “A los fenómenos (...) los construimos, o sea, les conferimos existencia ontológica, en definitiva, los construimos ontológicamente, al nombrarlos y al enunciarlos o representarlos. ... o sea, sólo se conoce lo enunciable (teniendo en cuenta que "lo enunciable" no equivale, sólo, a lo verbalizable, sino que abarca toda forma de enunciación semiótica, sea ésta mediante iconos, índices o símbolos; de dónde surge el texto pan-semiótico)" (Magariños de Morentín, 2008:75).
} 
Según Peirce toda la realidad puede ser comprendida a partir de tres categorías que permiten unificar aquello que es complejo y múltiple, a saber:

a) El primer correlato (o primeridad): es lo abstracto, como sucede con las cualidades, por ej. la cualidad de un color. El modo de ser tal cual es, positivamente y sin referencia a ninguna otra cosa.

b) El segundo correlato (o secundidad): son los fenómenos existentes, es lo posible realizado y por tanto es aquello que ocurre y se ha concretizado en relación con la primeridad: modo de ser en relación a un segundo. Lo segundo es pues siempre el fin, el elemento ocurrido, lo causado.

c) El tercer correlato (o terceridad): está formado por las leyes que rigen el funcionamiento de los fenómenos, es una categoría general que da validez lógica y ordena lo real. La terceridad realiza, el enlace lógico entre primeridad y secundidad, o sea, establece las condiciones hipotéticas para que algo ocurra.

"En resumen, el proceso triádico es el que domina la disposición analítica e interpretativa de la realidad desde el sistema del pensamiento humano. Este puede describir la situación global de las cosas como cualidades (primeridad), o en su acción real (secundidad) o como entidades regidas por leyes y fines (terceridad)." Y siempre como una experiencia continua y fluida."(Zechetto, 1999:49).

La primeridad es una relación de actuación o presencia. Es decir, se establece una relación cuya razón determinante consiste en el hecho de acotar, mediante el signo, el particular aspecto del objeto (fundamento) que es de interés para determinada comunicación. La secundidad es una relación de comparación o de cualidad. O sea, se establece una relación cuya razón determinante consiste en la posibilidad de concretarse, mediante el signo, una presencia de naturaleza semiótica (representamen). La terceridad es una relación de pensamiento o convencionalidad, con ella se establece una relación cuya razón determinante consiste en la necesidad que confiere consistencia, mediante el signo, al sistema del Interpretante. También pueden enunciarse como: de existencia (por algo), de forma (en alguna relación) y de ley (para alguien). 


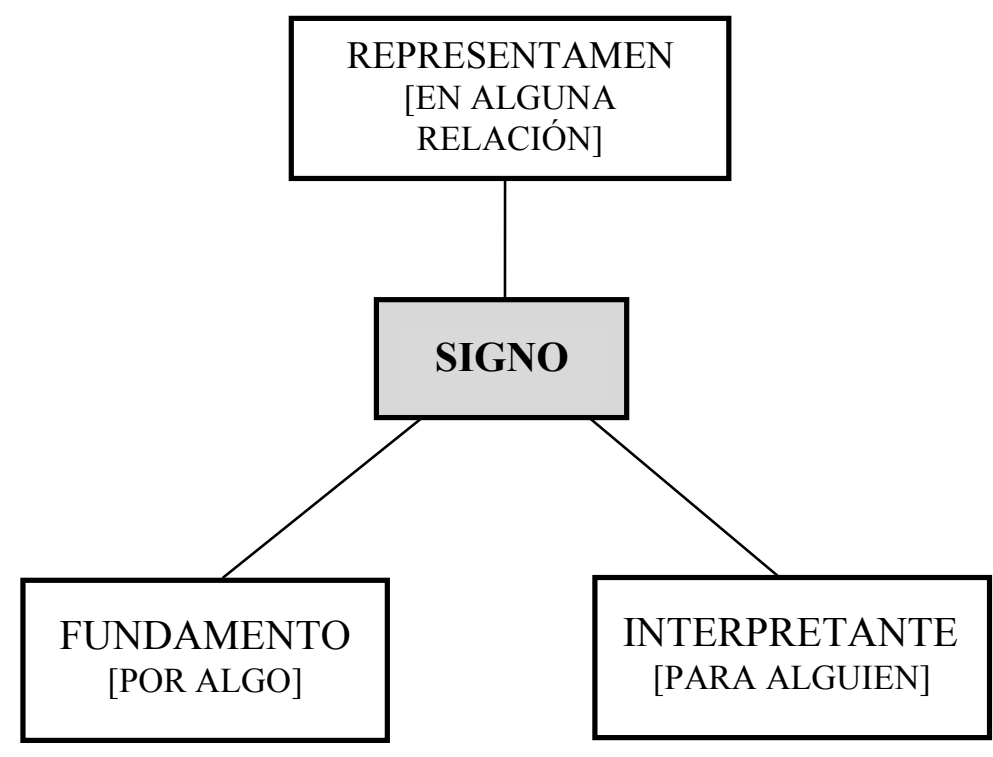

A partir de la definición de signo de Peirce y siguiendo la lógica de la construcción triádica podemos delimitar los referentes y niveles de interpretación.

El signo se produce en un ámbito semiótico que es la condición lógica de su existencia. Dentro de este ámbito el signo es la estructura estructurante en cuanto unidad mínima de análisis, no hay signo en tanto no se establece el ámbito semiótico que lo genera.

\section{III.4. El contexto de recolección: el objeto de colección y su condición de etnográfico}

A partir de la distinción que hace Peirce de los distintos tipos de signo, y estableciendo siempre las relaciones triádicas de sus componentes (fundamento, representamen e interpretante), es posible hacer explícita la estructura lógica desde la cual se definen los diferentes niveles semánticos en los cuales el objeto de colección se vincula con alguna otra cosa, a la cual, representa, según los contextos de quien lo produce, lo exhibe y lo observa.

Todo objeto de colección es objeto semiótico en tanto y en cuanto tienen atribuido un significado a partir de otra semiosis que lo enuncia. Debemos recordar que el proceso de adjudicación de significado es ilimitado. En presencia de un sujeto 
(intérprete), siempre será posible adjudicar significado a cualquier acontecer (representamen) a través de la operación de sustitución (fundamento). ${ }^{35}$ Llamamos a esta operación la facultad semiótica. El objeto de colección "en cuanto objeto semiótico recibe la eficacia de todos los discursos (o los que conozca el intérprete) que se han referido a él (en su particularidad o en su carácter general de comportamiento) (Magariños de Morentín, 2008).

En el estudio de colecciones, si bien es posible reconocer un conjunto de cualidades materiales que habitualmente han sustentado los estudios tipológicos, éstas no son, desde un punto de vista relacional, la condición de su posibilidad de representación, ni de su "existencia" como objeto de colección. Por definición, un objeto de colección adopta carácter de signo, es decir es una entidad que sustituye a otra y la representa, siempre y cuando sea posible dar cuenta de algún fundamento para algún interpretante. De este modo, el centro de interés se desplaza del objeto en sí al sistema relacional a partir del cual adopta un sentido.

Ese objeto de colección incorporado al contexto particular de la sala de exhibición es tratado como signo en la medida que posee su propia eficacia para construir un significado determinado que atribuirá a otro fenómeno diferente. O sea, el objeto semiótico recibe; el signo entrega. ${ }^{36}$

Las formas de organización de una colección en un museo pueden responder a diversos criterios de catalogación, muchas veces complementarios, y que habitualmente refieren al tipo de objeto, época, coleccionista, procedencia, entre otras.

Para una colección calificada como etnográfica la procedencia es un importante criterio diferencial, es decir, el reconocimiento de la comunidad o grupo étnico de pertenencia, portador de la cultura desde donde se asigna al objeto su valor. ${ }^{37}$

Se puede afirmar que adjudicar a un objeto el carácter de etnográfico implica

\footnotetext{
35 "Para que algo sea un Signo, debe "representar", como solemos decir, a otra cosa, llamada su Objeto, aunque la condición de que el signo debe ser distinto de su Objeto es, tal vez, arbitraria, porque, si extremamos la insistencia en ella, podríamos hacer por lo menos una excepción en el caso de un Signo que es parte de un Signo". (Peirce, 1986:23)

36 ... "tanto los objetos como los comportamientos pueden adoptar o ser considerados desde alguna de esas dos perspectivas: o son objetos semióticos y entonces la tarea es establecer de qué textos pansemióticos han recibido la calidad con la que son percibidos; o son signos y entonces son textos indiciales capaces de producir el significado de otra cosa diferente de ellos mismos." (Magariños de Morentín, 2008:73).

${ }^{37}$ En este trabajo se referencia al trabajo de campo como contexto de recolección, sin abordar el análisis histórico-político de la circunstancia de la recolección.
} 
reconocer un contexto de recolección pautado desde una situación de encuentro. Promovido por diversos intereses, el trabajo de campo acompañaba la recolección de objetos con un registro minucioso del "modo de vida" de los grupos estudiados. Es decir, que una colección es calificada como etnográfica por una condición que hereda desde el momento de su recolección: la presencia del sujeto creador o grupo cultural de pertenencia.

Este contexto de origen es recuperado en el ámbito de un museo a partir de los diversos registros, a saber, libretas de campo, publicaciones, fotografías, textos etnográficos, entre otros. A su vez, la descripción exhaustiva de sus condiciones materiales y características morfológicas, completa y define junto a los datos secundarios, los niveles interpretativos que incluyen sistemas descriptivos, funcionales y simbólicos.

Ahora bien, desde este punto de vista, necesario y válido para la organización de un museo, la colección es pensada como un sistema cerrado, limitando las posibles interpretaciones y con ello, sus potencialidades expositivas. Los valores aparecen como fijos y atrapados en la materia, y su análisis adopta un carácter reconstructivo que evoca, a través de la cultura material, a un sujeto ausente.

Esta adjudicación mecánica de sentido que busca la adecuación entre el objeto y porciones de discurso etnográfico, corre el peligro de promover un concepto reduccionista y estático de cultura, la mayoría de las veces en referencia al pasado. Generalmente se expresan en una modalidad expositiva en la que se deposita en el objeto en sí el poder evocativo acerca de la cultura, dejando al sujeto intérprete fuera de la secuencia analítica e implicado sólo en un proceso selectivo de "lo dicho" por otros.

Esta característica se ve reforzada en el estudio de la cultura material por sus posibilidades de manipulación, la cuantificación de sus caracteres, la perdurabilidad de sus condiciones, lugares donde descansa su condición de autenticidad y evidencia. Sin embargo, todo objeto podrá ser interpretado sólo si se lo incluye en un contexto, ya que, como hemos visto, los valores no están en los objetos sino que dependen de las valoraciones que de ellos hacemos (Mathieu, 1987). Es así que un mismo objeto admite distintas lecturas según el marco de referencia elegido para desbordar los límites de su materialidad e ingresar en un campo más difuso e interpretativo.

"Al hacer explícitas las convenciones que ponemos en juego en muestras cadenas de razonamiento (como en la extracción de conocimiento) definiendo como 
motivo la búsqueda de relación: intuición/regla, regla/propiedad sensible, propiedad sensible/dimensión, dimensión/entendimiento, entendimiento/configuración, podemos controlar nuestros propios determinismos." (Lahitte, 1996:60).

El análisis de una colección admite, entonces, un tratamiento formal según las cualidades sensibles a partir de la cuales se podrán reconocer los niveles analíticos. El reconocimiento de diferentes sistemas de relaciones asciende desde los niveles más concretos y descriptivos -dimensiones, forma, materia prima, entre otras- hacia niveles más abstractos o diferentes tipos lógicos. En todos ellos opera la definición de categorías de inclusión y contraste. En estos sistemas relacionales el objeto puede ocupar diversos lugares dentro del campo semántico, puede ser el centro desde donde irradian las variables o ser desplazado hacia la periferia para aportar a diversas unidades temáticas. La profundidad del análisis estará dada por los objetivos y la validez de las distinciones de rasgos, atributos y relaciones al interior del corpus. Así, accedemos, en primer lugar, al conjunto de rasgos con capacidad descriptiva en un corpus dado y cuya relación define el tipo de referente. Consiste en el conjunto de rasgos que responden a los requisitos morfológicos por los cuales un elemento es incluido en un tipo y distinguido de otro conjunto. Ej.: la condición de cubrir el rostro es un rasgo pertinente a la definición de máscara. La condición de contenedor de algún elemento es un rasgo distintivo de la categoría recipientes. Así, por contraste o inclusión se identifican, en segundo término, aquellos rasgos compartidos por un subtipo y cuya relación define una identidad de clase. Es decir, características morfológicas diferenciales que definen, por ejemplo, tendencias estilísticas. Por último, se identifican los rasgos que definen aun objeto único y cuyas relaciones le otorgan identidad individual.

A partir de aquí es posible sistematizar las particularidades formales del objeto y retener las similitudes y diferencias de un objeto a otro, pudiendo ser reconocidos aquellos elementos y sus modos de combinación que le otorgan a cada una su carácter representativo. Es decir, permite identificar los sistemas relacionales que dentro de una gran variedad de combinatorias, mantiene ciertas constantes en su articulación, poniendo de manifiesto los elementos estructurales.

Llamaremos a este primer nivel de análisis sistema analítico-descriptivo, concebido como una red de relaciones formales. Un segundo nivel o sistema funcional que alude al conjunto de acciones y actitudes, circunstancias de uso, 
confección, participantes, que reflejan una práctica social. Permite leer la correspondencia entre la forma, la materia y la función específica que le es culturalmente asignada al objeto.

Por último, el sistema simbólico que refiere al ámbito de los significados que cada comunidad da al referente objeto.

¿De qué manera la información acerca de una cultura se encuentra contenida en la materia? ¿Qué conjunto de relaciones contextuales permiten trascenderla y abordar sus significados?

Sabemos que antes de ser construido el objeto fue pensado, la técnica, antes de ser utilizada, fue aprendida, la materia, antes de ser modelada, fue adquirida, fue concebida como posibilidad. Su análisis devela aspectos multifacéticos y sus mensajes podrán ser decodificados en la medida en que se los incluya en contextos significativos, creando así un juego de correspondencias entre las diferenciaciones formales y sus significados funcionales, estilísticos, simbólicos, económicos, sociológicos, étnicos, entre otros (Bromberger, 1979).

El objeto etnográfico ocupa un lugar entre otro conjunto de documentos tales como textos etnográficos, libretas de campo, registros fílmicos y fotográficos, por medio de los cuales es posible recomponer sus usos y significados en una cultura en particular. Como dijimos, esto ha llevado, en algún caso, a restringir el análisis de colecciones a una práctica de adjudicación de sentido basada en la correspondencia del discurso etnográfico con el objeto aludido. Sin embargo, la relación entre el nivel formal de las cualidades materiales (sistema analítico-descriptivo) y los niveles funcional y simbólico son los espacios depositarios de valor identitatario y de pertenencia étnica. Los valores que adquieren las distintas variables de análisis están siempre situados en tiempo y espacio. La dinámica social y cultural supone un proceso constante de resignificación.

En esta tesis, este es el primer contexto de significación y queda denominado como contexto de recolección. El mismo alude al conjunto de significados que una comunidad dada otorga a la cultura material, en un momento determinado. Este es recuperado por una serie de documentos, que identificamos como dato etnográfico.

Contexto de significación I: desde el cual se otorga al objeto signo su condición de etnográfico. 
Cuadro 1

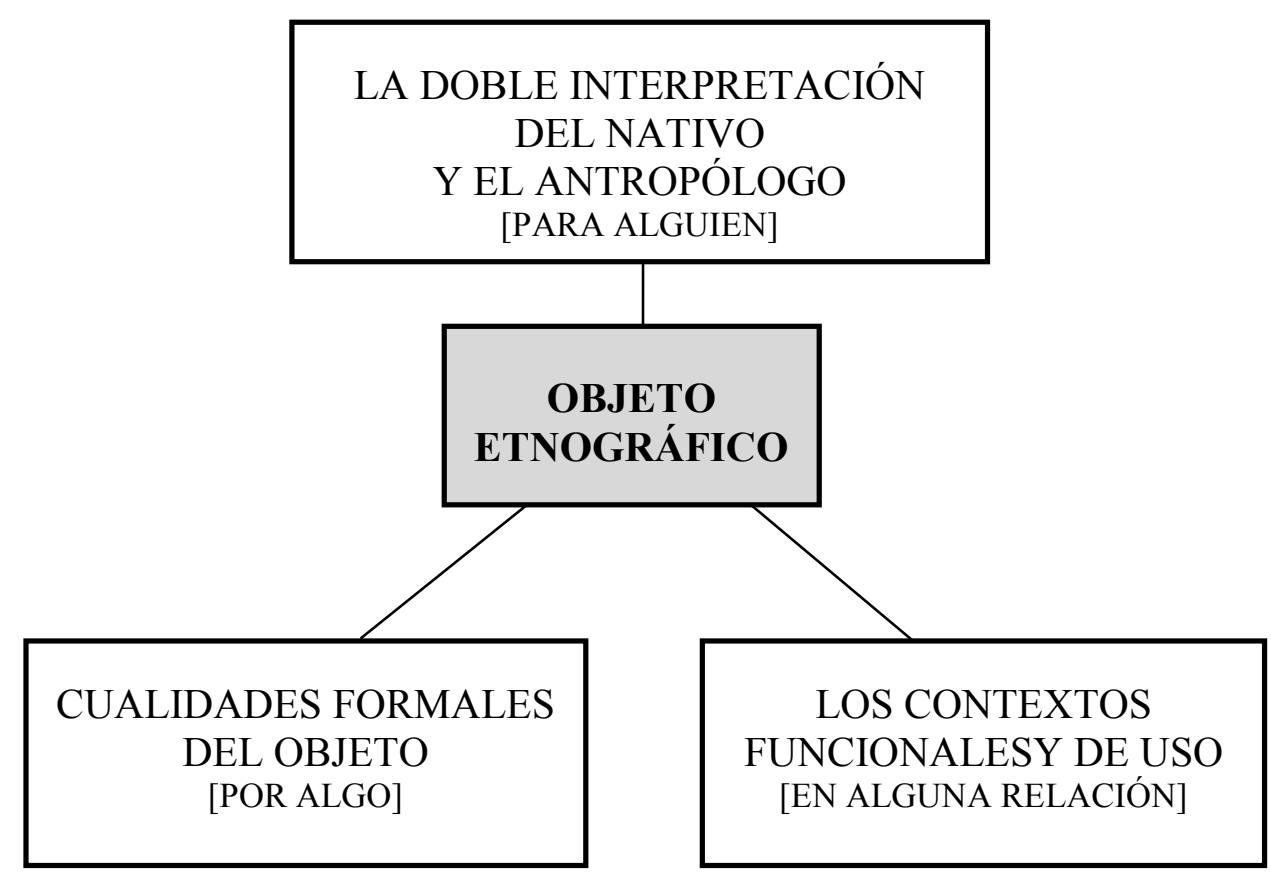

\section{III.5. El contexto de re-presentación: la sala de exhibición como espacio} intersemiótico

La sala de exhibición es concebida, desde el punto de vista comunicacional, como un espacio intersemiótico. En ella se configuran, de modo intencional, los diversos recursos expositivos, que dan forma y materializan el relato expositivo. Así, es posible reconocer un espacio significante, estructurado según ciertas reglas y cuyas posibilidades de re-presentación (icónica, indicial y simbólica) radica en su condición de sustitución. Pero, a su vez, para su incorporación en un circuito comunicacional, la sala es un objeto semiótico, es decir, es concebida como signo siempre y cuando sea posible reconocer un intérprete y responder a la triple relación pierciana "estar en lugar de algo", "para alguien" y "en alguna relación". "Cuando se desea distinguir entre aquello que representa y el acto o relación de representar, lo primero puede ser llamado el "representamen” y lo segundo la "representación." (Peirce, 1986:43).

"El signo o representamen es algo que, para alguien, representa o se refiere a algo en algún aspecto o carácter. Se dirige a alguien, esto es, crea en la mente de esas personas un signo equivalente, o tal vez, un signo aun más desarrollado. Este signo creado es lo que yo llamo el interpretante del primer signo. El signo está en lugar de algo, su objeto. Está en lugar de ese objeto no en todos los aspectos, sino sólo con 
referencia a una suerte de idea, que a veces he llamado el fundamento del representamen." (Pierce, 1986: 22).

La elección de las distintas semiosis (icónica, simbólica e indicial) y su combinación en la configuración de un espacio expositivo no responde a los requisitos de modernización impuestos a este tipo de institución en las últimas décadas ante las nuevas demandas del público. La incorporación de nuevas tecnologías no garantiza, por sí sola, el cumplimiento de los objetivos. Su eficacia comunicativa reside en la posibilidad de generar ciertas asociaciones cognitivas, las posibilidades de construcción de sentido acotado según las intenciones de los curadores. No hay por definición un recurso expositivo que dé cuenta de una idea de forma unívoca. No hay una disposición espacial de los objetos de colección que pueda ser pensada como la forma obligada para la mejor interpretación. Las posibilidades de combinación se nos presentan de forma casi ilimitada, y cada concreción es el resultado del análisis explícito y la elección consciente en función de un objetivo. Cada elección, cada contexto de interpretación y cada disposición en el recorrido, responde a una intención desde la cual se verifica o no cierta correspondencia entre la idea y su expresión. La explicitación de los criterios que gobiernan dichas elecciones es el resultado de un proceso que tiende a reducir la arbitrariedad propia de la construcción sentido. En este espacio intersemiótico, cada signo adquiere su especificidad pero su interpretación no será posible sino en el conjunto de las relaciones contextuales.

“Afirmar la discursividad del mundo es no sólo un postulado de partida, sino también una manera de restringir el campo de estudio eligiendo un punto de vista desde el que proceder el análisis. Partiendo de su carácter cultural -histórico- tratar (al museo) como lugar- como espacio, más en concreto, en el que se expresa su significación.” (Zunzunegu, 2003:12) De esta manera puede llevarse a cabo un estudio integrado de la significación de un espacio y de las acciones que en él se desarrollan, tanto desde la construcción de un espacio reglado y su condición de representación como desde la apropiación del mismo en su interpretación.

En consecuencia, la sala de exhibición consiste en un espacio acotado de significación en cuya articulación emerge el sentido. Un campo de confluencia entre las intenciones del curador, del productor de objetos y los supuestos que el visitante trae a la muestra. Un campo complejo y dinámico que genera infinitas conexiones, en muchos casos no prevista. 
Lo que llamamos el mundo sensible se convierte así en el objeto, sin exclusión de ninguna parcela, de la búsqueda de la significación; el mundo se revela en su conjunto y en sus articulaciones más menudas, como una virtualidad de sentido o condición que sea sometida a una forma por lo menos mínima. Por obra de esta forma, la significación puede introducirse bajo todas las apariencias sensibles. Así, está detrás de los sonidos, las imágenes, los olores y de los sabores, sin que por ello esté en ellos en cuanto puros soportes informes de nuestra percepción formadora (Zunzunegui, 2003).

Contexto de significación II: desde el cual se otorga al objeto etnográfico su condición de objeto museable.

Cuadro 2

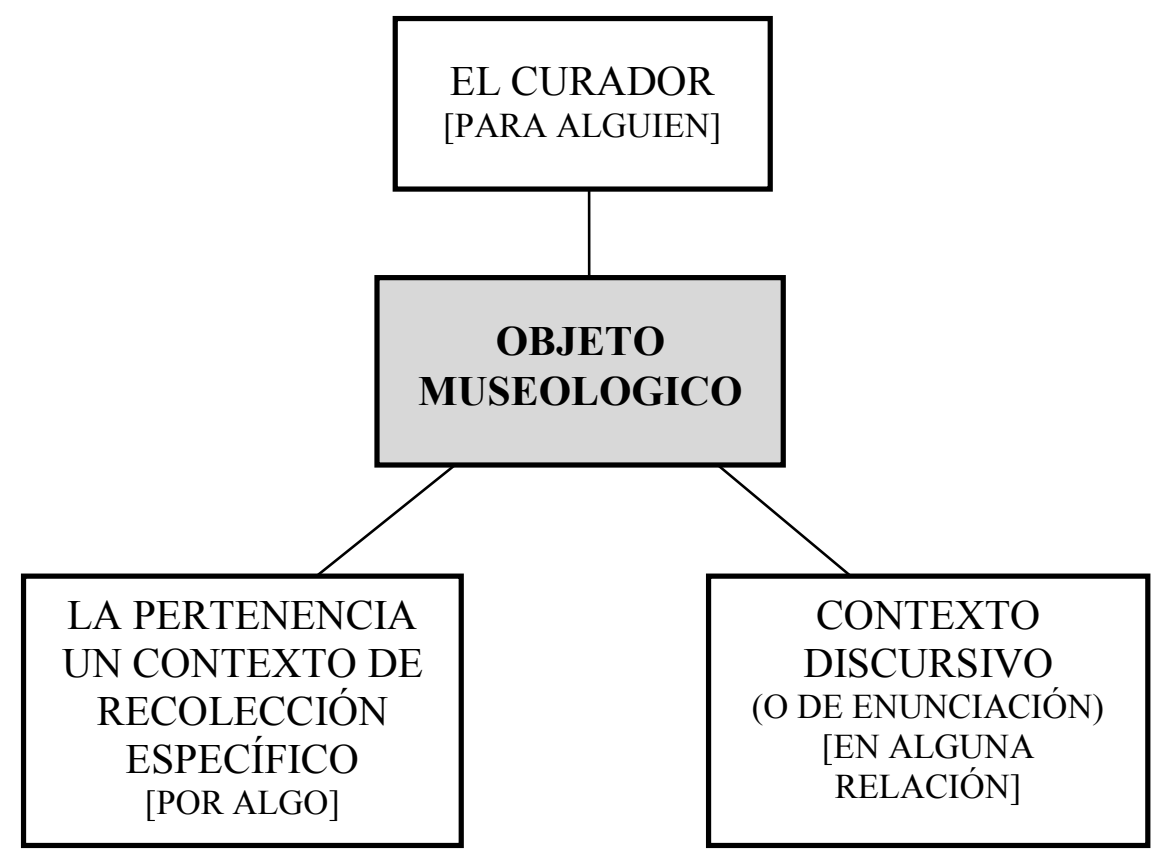

En el cuadro 1, se expresan las relaciones triádicas por las cuales el objeto etnográfico se constituye como signo en una sala de exhibición. El cuadro 2, alude al fundamento por el cual la sala de exhibición es un signo interpretable por los visitantes. La relación entre ambos corpus permite pensar a la sala de exhibición como la instancia de re-presentación que mediatiza el conocimiento del Otro cultural.

Todo signo es a su vez una parte de otro signo, de manera que la definición de estos niveles es el resultado del interés analítico que lo justifica. En cada uno de ellos se pueden reconocer múltiples contextos de significación según el modo en que un objeto semiótico sea interpretado dentro del sistema. A partir de la relación entre estos tres 
componentes es que el objeto semiótico adquiere un valor. Desde allí se explicitan los caminos argumentales y cognitivos para la construcción de sentido.

Para cada contexto es pertinente distinguir por un lado al interpretante productor de la semiosis sustituyente y el interpretante intérprete de la semiosis sustituida u objeto semiótico. Así podemos reconocer dos circuitos de relación: en el contexto de recolección el interpretante productor es el "nativo" y el interpretante intérprete es el antropólogo; en el contexto de re-presentación el interpretante productor es ese sujeto colectivo que desde la producción generada desde el contexto de recolección produce una nueva semiosis sustituyente para el interpretante intérprete, los visitantes.

El interpretante productor, a través nuevamente de un proceso de distinciones, atribuciones y relaciones propone ciertas relaciones sintácticas y semánticas entre los distintos representámenes (icónicos, indiciales y simbólicos) con las que trata ideológicamente de que "veamos el mundo tal como puede verse desde esta propuesta sintáctica que nos está ofreciendo). ..."lo ideológico no es una práctica, sino una dimensión, teóricamente determinada, de cualquier práctica social. Tampoco es un nivel de significación, sino la condición de posibilidad de existencia de cualquier “nivel” de significación.” (Peirce, 1986:12) De allí que la sala de exhibición responda al conjunto de supuestos teóricos propios de una disciplina.

Las intenciones del primer interpretante, ese sujeto colectivo que busca materializar las ideas en la textualidad de la sala, propone, al segundo interpretante, también conformado por ese sujeto colectivo y anónimo que es el visitante, un espacio reglado, un espacio significante e intersemiótico en cuya sintaxis combina los diferentes recursos expositivos, es decir, las semiosis sustituyentes. Las elecciones en cuanto a las distintas semiosis, su acomodación y distribución, los contextos significantes, son el resultado de una acción intencional por parte de los curadores. La sala resulta ser un espacio reglado, configurado bajo ciertos preceptos, en un marco ideológico particular que busca intencionalmente provocar en el visitante cierto recorrido, actitudes; es un espacio reglado que ejerce un efecto estructurante de la visita, condición que algunos autores como Zunzunegui han denominado con el término manipulación. Así, se reconoce en la misma disposición espacial, por un lado, el ejercicio de una competencia destinadora que predetermina las performances de los sujetos receptores individuales o colectivos y, por otro, la construcción de un enunciatario implícito en tanto que usuario 
modelo de ese espacio formalizado que lleva a cabo una serie de acciones predeterminadas. Para esto es necesario reconocer la existencia de, al menos parcialmente, una organización del espacio y una distribución de los objetos que constriñe a los actantes a recorridos estereotipados de reconocimiento (Zunzunegui, 2003).

\section{III.6. EI contexto de apropiación: los discursos de los visitantes}

Cada visitante trae consigo un universo cultural, expectativas, necesidades, experiencias, prácticas y representaciones que se "activan" en el espacio comunicativo propuesto por la exhibición. A su vez, percibe, distingue, selecciona e interpreta los diversos contextos temáticos que agrupan objetos, textos e imágenes "cargados" de significación. $\mathrm{Su}$ apropiación es diferencial e involucra procesos cognitivos y emocionales que permitirán el "acoplamiento" de la experiencia de la visita con estructuras preexistentes, es decir, según un conjunto de hábitos cognitivos.

Existe mayor afinidad entre aquellas imágenes que veo y otras imágenes con las que estoy familiarizado, que percibí históricamente. "En mi estructura conceptual se asocian conceptos semánticos, percepciones visuales y (sin agotar componentes) experiencias kinésicas, que me permiten construir, con las percepciones que pude asimilar en esta situación, un referente proyectado que interpreto como para permitirme decir de él (...) sé lo que veo porque lo sitúo como objeto actual de otras representaciones. (...) queda así caracterizado como objeto semiótico.” (Magariños de Morentín, 2008:79).

Desde distintos ángulos, la lingüística, la semiótica y la perspectiva más moderna de la teoría de la comunicación han mostrado que el significado proviene tanto de una voluntad normativa socialmente aceptada y compartida (los signos, simbólicos y el aspecto simbólico de todos los signos) como de una fijación de determinadas relaciones contextuales socialmente aceptada y compartida (los signos indiciales y el aspecto indicial de todos los signos). Es decir que el significado (o valor) mínimo de cualquier signo está constituido por el conjunto de sus posibilidades de relación con los restantes signos de la misma semiosis (Magariños de Morentín, 2008). ${ }^{38}$

\footnotetext{
${ }^{38}$ (...) "la atribución es una de las operaciones básicas de la semiótica y, en ese lugar defino esa operación como "aquella mediante la cual se pone en relación una forma con un valor, o sea, se le atribuye una valor a una forma, habiendo establecido previamente a que, siendo forma la existencia posible del resultado de una percepción sensorial, corresponde entender por valor la relación entre (al menos) dos formas, estableciéndose, así la relación contextual mínima como la condición necesaria que
} 
Por el momento nos limitaremos a reconocer, siguiendo el esquema pierciano planteado más arriba, los elementos que configuran un nuevo contexto de significación, denominado de apropiación, ya que el conjunto de interacciones comunicativas producidas en la sala de exhibición será tratado en el capítulo cinco.

Este contexto es el resultado de la situación comunicativa que ubica al visitante en su condición de interpretante y a la sala de exhibición como re-presentación de un “otro” cultural. Así, el objeto adquiere su condición de objeto museográfico.

En cada contexto de inclusión se actualiza el significado, logrando su vigencia. Así, la noción de contexto se enlaza a la de productividad de sentido, que será recuperado, en esta tesis, a partir de la aplicación de operaciones analíticas estandarizadas a los discursos producidos por los visitantes. Si las unidades que integran un contexto son unidades discretas, o sea, acotadas diferencialmente en cuanto formas perceptuales y con normas explícitas acerca de cómo producir la interrelación de tales entidades para la producción de determinada significación, el análisis contextual es factible y puede exponerse con rigor explicativo. (Magariños de Morentín, 2008).

Contexto de significación III. (La condición de objeto museográfico)

Cuadro 3

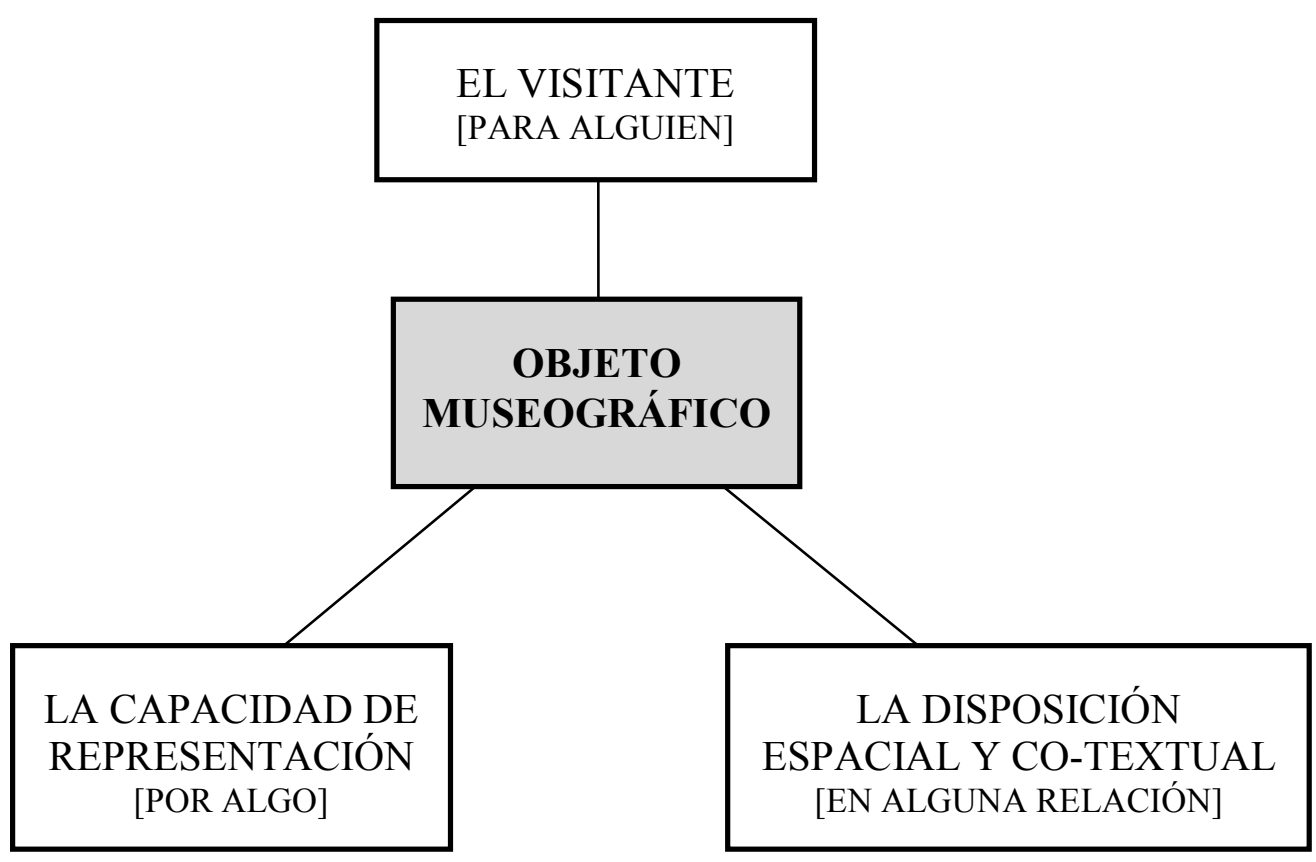

se actualice una calidad semántica mínima: semántica intrasemiótica que constituye una sintaxis." (Magariños de Morentín, 2003:363). 


\section{III.7. Inter-relaciones y re-presentación}

Las relaciones establecidas dentro del contexto de recolección (primer correlato) generan las posibilidades de relación de un nuevo contexto de significación en la sala de exhibición (segundo correlato). En el pasaje de un contexto a otro es que se instala el desarrollo de estrategias como fundamento para asignar su condición de re-presentación (tercer correlato). Las inter-relaciones entre los tres contextos es el lugar donde se desarrollan las estrategias discursivas (icónicas, indiciales, simbólicas).

El contexto de apropiación se define a partir del reconocimiento de los visitantes como interpretantes/intérpretes (como producto de la experiencia cognitiva producida por interacción con el contexto II y donde se da la producción de sentido, materializada en los discursos enunciados, (lo dicho). El contexto III (de apropiación) se conecta con el contexto I (de recolección) mediatizado por el contexto II (de re-presentación).

La construcción analítica (modelo) de cada uno de estos contextos es:

- Diferencial: cada contexto es el resultado de la extracción de distinciones, unidades mínimas en cuyas relaciones se delimitan sus límites, siempre arbitrarios.

- Relacional: la distinción interpretante/intérprete es el resultado de la coconstrucción desde la relación establecida. Esta relación se define en cada uno de los contextos planteados. ${ }^{39}$

- Recursiva: en la medida en que es posible reconocer entre los contextos relaciones de producción - causación. Cada contexto se nutre del otro en un proceso de retroalimentación. (mecanismos de retroacción). ${ }^{40}$

- Dialógica: contextos que parecen oponerse pueden encontrar complementariedad en otros niveles de análisis.

- Abductiva: los postulados analíticos pueden ser aplicados a otros ámbitos de indagación, pero como modelo causal de análisis y no como resultado verdadero en sentido positivista, ya que el enlace entre las premisas y la conclusión es de tipo hipotético. ${ }^{41}$

\footnotetext{
${ }^{39}$ Lahitte, H. 1996.

${ }^{40}$ Morin, E. 2007.

41 “...los actos abductivos son "creativos", ya que se apoyan sobre hipótesis de "intuición y adivinación" como la forma más común que tiene el ser humano de indagar su entorno. En los procesos de semiosis, la abducción abre las puertas a la invención por su afinidad con la adivinación cognitiva, pero no como si
} 


\section{Relaciones entre contextos}

Cuadro 4

\begin{tabular}{|c|c|c|c|}
\hline & $\begin{array}{l}\text { EN ALGUNA } \\
\text { RELACION }\end{array}$ & POR ALGO & PARA ALGUIEN \\
\hline $\begin{array}{c}\text { CONTEXTO DE } \\
\text { RECOLECCIÓN } \\
\text { I }\end{array}$ & $\begin{array}{c}\text { Contexto analítico- } \\
\text { descriptivo y funcional } \\
\text { y simbólico del objeto } \\
\text { etnográfico. }\end{array}$ & $\begin{array}{l}\text { Cualidades formales } \\
\text { del objeto, } \\
\text { documentos, fotos, } \\
\text { etc. }\end{array}$ & $\begin{array}{l}\text { Interpretación a } \\
\text { partir de la relación } \\
\text { nativo-antropólogo. }\end{array}$ \\
\hline $\begin{array}{l}\text { CONTEXTO DE } \\
\text { REPRESENTA- } \\
\text { CIÓN } \\
\text { II }\end{array}$ & $\begin{array}{l}\text { Contexto discursivo } \\
\text { disciplinar. }\end{array}$ & $\begin{array}{l}\text { La pertenencia a un } \\
\text { contexto de } \\
\text { recolección } \\
\text { específico. }\end{array}$ & $\begin{array}{c} \\
\text { El curador } \\
\text { (sujeto colectivo). }\end{array}$ \\
\hline $\begin{array}{c}\text { CONTEXTO DE } \\
\text { APROPIACIÓN } \\
\text { III }\end{array}$ & $\begin{array}{l}\text { La disposición espacial } \\
\text { y contextual en la sala } \\
\text { de exhibición. }\end{array}$ & $\begin{array}{l}\text { Discurso enunciado } \\
\text { a partir de la } \\
\text { experiencia de la } \\
\text { visita. }\end{array}$ & El visitante. \\
\hline
\end{tabular}

fuese un conocimiento al azar sino con base de argumentos de alguna manera previstos y razonables." (Zecchetto, 1999:66). 


\section{Capítulo IV ESPEJOS CULTURALES \\ LA SALA ETNOGRAFÍA DEL MUSEO DE LA PLATA}

"La etnografía nos pone en contacto con lo ajeno partiendo de lo propio. Esta aproximación a lo extraño, al mundo de los otros, implica siempre una referencia, por contraste o similitud, a la realidad que conocemos: a nuestro mundo. Ello hace que las descripciones etnográficas y los modelos a que dan lugar sean, también, proyecciones alegóricas de la propia cultura.” (L. Díaz Viana, 1991). 


\section{IV.1. Espejos culturales: alcances de la innovación}

La nueva propuesta expositiva de sala permanente de etnografía del Museo de La Plata, "Espejos Culturales", dedicada a la diversidad cultural, está organizada según diferentes ejes de información que se yuxtaponen en el espacio expositivo y que son el resultado del análisis relacional de un conjunto de presupuestos teóricos. Son éstos presupuestos los que funcionan como ideas rectoras y los que serán traducidos al espacio tridimensional a través de diferentes recursos museográficos. Esta remodelación completa, que incluye lo conceptual, la conservación, la infraestructura edilicia y arquitectónica y la incorporación de recursos interactivos y mediáticos, busca promover en el visitante una experiencia perceptiva más amplia, que identifique en el recorrido instancias de reflexión en las que se sienta diferencialmente involucrado $\mathrm{y}$, de esta manera, superar los límites de la materialidad de los objetos presentados para ingresar en el campo de sus significaciones. Sin perder de vista la organización temperoespacial y la procedencia étnica como referente ineludible, se pretende que la experiencia de la visita conjugue tanto el encuentro de racionalidades como sentimientos de atracción, curiosidad, sorpresa y "goce" estético ya que la experiencia de aprendizaje involucra, siempre, algún estado emocional.

Según el análisis precedente podemos ubicar el espacio expositivo como la materialización de lo que hemos llamado el contexto de resignificación/representación anclado en el contexto de recolección y construido bajo las intenciones curatoriales que permiten prescribir el contexto de apropiación.

El conjunto de los objetos de colección se integra así a distintas redes de significación, estructuradas según lógicas y lenguajes diferentes. La tarea de traducción/transformación del estatus del objeto según los intérpretes/interpretantes requiere tanto del conocimiento disciplinar como de la creatividad y la imaginación. Un recorrido que incluye la confrontación, selección y decisión. En la literatura museológica estas instancias, con diferencias sutiles, se encuentran expresadas como el guión científico, el museológico y el museográfico. La condición sistémica y abierta de este desarrollo implica la circularidad y la retroalimentación entre todas las instancias. ${ }^{42}$

${ }^{42}$ A su vez, este proceso constructivo se entrecruza con las distintas áreas de trabajo propias de la estructura organizativa de la institución museo. Esta instancia agrega más elementos a la complejidad aludida pero no será tratada en este trabajo. 
En el marco restrictivo de condicionantes materiales, espaciales, históricas, económicos y políticas, se trata del ejercicio creativo de producir un resultado, sin perder de vista los objetivos planteados, el marco institucional, la naturaleza de los contenidos de la exposición y, por sobre todo, el tipo de experiencia que se pretende promover en los visitantes.

En este sentido, Bernard Deloche refiere a la importancia del estudio de los modos de percepción por parte del visitante. Si bien su análisis toma como referencia los museos de arte, sus consideraciones teóricas trascienden esta categoría, ya que, desde algún punto de vista toda presentación es una suerte de virtualidad, en el sentido de imagen construida. De allí que adjudique un valor destacado al encuentro de la razón y el sentir en la tarea de presentación del patrimonio en las salas de exhibición, tarea que denomina como expografía, destacando en la naturaleza propia de este quehacer el vínculo presentación-percepción. En tal sentido expresa (...) “es indispensable asignar al museo la doble tarea: (1) de mostrar las obras al público, pues modelan su mirada por medio de las experiencias sensomotrices que se le ofrecen (función de exposición), y (2) poder estudiarlas atentamente para tener el control de los espacios y de las imágenes que las presentan, para lo cual es necesario sobre todo establecer relaciones o reconstruir series (función de estudio o de la medida), pues se trata de comprender mejor los efectos de la experiencia perceptiva, modulando el espacio de presentación de una obra, por ejemplo, o modificando experimentalmente el contexto, o también haciendo variar la propia obra en su encuadre, sus tonos, sus contrastes, etcétera. Así entendido, el museo promete convertirse en el principal instrumento de las ciencias cognitivas aplicadas a los efectos sensomotrices de la imagen, quizás por ello la programación de los museos tiene cada vez más en cuenta el comportamiento del público y se dota de herramientas de evaluación de sus reacciones. Estos estudios, lejos de ser ajenos a la tarea de exposición, se refieren directamente a los efectos de la presentación.

Comunicación y análisis son, pues, las dos funciones principales que le han tocado en suerte al museo, junto con la de la colección. No solo la presentación de lo sensible y el análisis sistemático de lo que se presenta están lejos de ser incompatibles, sino que una y otro se ejercen gracias a la expografía. Se ha hablado del museo como un lugar; más valdría, sin duda, entenderlo como un espacio experimental de presentación.” (Deloche, 2002:85). 
Debemos recordar que cada exhibición es una de las formas posible de dar cuenta de un conjunto de ideas. La apertura hacia la multiplicidad de miradas impregna todos los niveles de acción museológica. Lo definitivamente observable, perceptible e interpretable no refleja la complejidad y dinámica de esta labor.

El producto final como espacio significante puede ser concebido, tomando la propuesta de Eco como una "obra abierta". Como vimos, el espacio expositivo está regido por convenciones, ya que la disposición y organización interna no es totalmente azarosa y, en consecuencia promueve y en algún caso regula cierto comportamiento por parte del visitante; y aún más, a partir de las ideas rectoras se pretende orientar la interpretación resultante de la visita y no posterga en su concepción primaria los grados de libertad que todo intérprete maneja en cualquier situación comunicativa. Sin embargo, este último punto no se agota en la condición de interpretante del sujeto visitante, sino que es provocada intencionalmente por el uso y combinación de los distintos recursos, que encierran en su concepción diversos grados de apertura hacia la incertidumbre, apelan a lo sensible y se desarrollan en su dimensión estética.

Refiriéndose a la obra de arte en general Eco comenta "Estas nuevas formas (...) consisten, en cambio, no en un mensaje concluso y definido, no en una forma organizada unívocamente, sino en una posibilidad de varias organizaciones confiadas a la iniciativa del intérprete, y se presentan, por consiguiente, no como obras terminadas que piden ser revividas y comprendidas en una dirección estructural dada, sino como obras "abiertas" que son llevadas a su término por el intérprete en el mismo momento en que las goza estéticamente. (...) una obra de arte es un objeto producido por un autor que organiza una trama de efectos comunicativos de modo que, cada posible usuario pueda comprender (a través del juego de respuestas a la configuración de efectos sentida como estímulo por la sensibilidad y por la inteligencia) la obra misma, la forma originaria imaginada por el autor. En tal sentido, el autor produce una forma conclusa en sí misma con el deseo de que tal forma sea comprendida y disfrutada como él la ha producido; no obstante, en el acto de reacción a la trama de los estímulos y de comprensión de su relación, cada usuario tiene una concreta situación existencial, una sensibilidad particularmente condicionada, determinada cultura, gustos, propensiones, prejuicios personales, de modo que la comprensión de la forma originaria se lleva a cabo según determinada perspectiva individual.” En la obra abierta, el artista "en vez de sufrir la "apertura" como dato de hecho inevitable, la elige como programa productivo e 
incluso ofrece su obra para promover la máxima apertura posible.” (Eco, 1992:73).

En este capítulo se presenta una descripción lo más detallada posible de las ideas principales, los recursos y las intenciones hacia el visitante en la concreción de la sala, la que será, en los siguientes capítulos motivo de un estudio cualitativo de público. ${ }^{43}$

La sala etnografía fue inaugurada el 27 de marzo de 2007 y abierta al público tres semanas antes. El término etnografía alude a la "etnografía tradicional" entendida como la descripción exhaustiva de los diversos modos de vida, centrados fundamentalmente en los grupos denominados en distintas épocas como indígenas, primitivos, grupos étnicos y actualmente pueblos originarios.

Si bien la etnografía hace por lo menos dos décadas ha ingresado fuertemente en el análisis de la sociedad compleja, los conjuntos temáticos de la sala aparecen vinculados con las colecciones de la División Etnografía del Museo, en su mayoría pertenecientes a las primeras décadas de la historia del museo hasta aproximadamente los años 50-60, y con algunos ingresos aislados en los años siguientes.

La sala, antes de su remodelación, presentaba la cultura material procedente tanto de culturas extra americanas como americanas; en la actualidad está dedicada especialmente a los pueblos originarios de Argentina y América.

La nueva propuesta de exhibición se sustentó en el análisis crítico del estado anterior, promoviendo un giro en torno a ciertos principios explicativos propios de la disciplina antropológica, atravesados, a su vez, por los nuevos paradigmas museológicos. Es decir que, el ejercicio reflexivo por parte del equipo consistió en establecer vínculos significativos entre las ideas rectoras y los recursos expositivos empleados. El cambio propuesto respondió a un doble requisito, por un lado adecuarse a un nuevo conjunto de presupuestos, por otro, circunscribirse a las limitaciones estructurales del espacio expositivo. ${ }^{44}$

Se intentará traducir en un lenguaje descriptivo la articulación tridimensional del espacio expositivo. Para esto se hará alusión a los ejes y redes conceptuales, los

\footnotetext{
43 Las dificultades de traducir en palabras el espacio tridimensional son salvadas con la incorporación de un breve video que dará al lector una perspectiva del conjunto más completa.

44 El reconocimiento de este doble requisito implica, por un lado, la ineludible inclusión del sujeto (contexto de las ideas), por otro, el cuestionamiento a las posturas para las cuales la actualización de una sala de exhibición se reduce a una nueva acomodación de objetos al interior de una vitrina o la incorporación de novedades tecnológica.
} 
espacios y sectores y los recursos utilizados. Este "cartografiado" toma como referencia los tópicos de información y las distinciones que dan cuenta de los elementos diferenciales que materializan el conjunto de ideas o principios explicativos.

Toda descripción es necesariamente, el cartografiado sobre alguna superficie, matriz o sistema de coordenadas de las derivaciones de los fenómenos que se pretenden describir. Este enunciado se sustenta en el principio de distinción de los niveles lógicos entre un referente y su descripción. Dicho principio actúa en cualquier instancia de representación/interpretación, subyace a cualquier acto de semiosis sustitutiva. Citando a Korziybsky, G. Bateson enuncia "El mapa no es el territorio, y el nombre no es la cosa nombrada." La distinción lógica entre el nombre y la cosa nombrada implica una transformación, y ese es justamente el lugar donde se filtran nuestras intensiones: "en todo pensamiento, o percepción, o comunicación de una percepción, hay una trasformación, una codificación, entre la cosa sobre la cual se informa, (...) y lo que se informa sobre ella. En especial, la relación entre esa cosa misteriosa y el informe sobre ella suele tener la índole de una clasificación, la asignación de una cosa a una clase. Poner un nombre es siempre clasificar, y trazar una mapa es en esencia lo mismo que poner un nombre." (Bateson, 1990:27).

La distinción entre una clase y sus miembros es un principio ordenador. La organización de los distintos niveles de inclusión expresados en el espacio expositivo y sus relaciones darán cuenta, a modo de cartografiado, del andamiaje lógico formal desde donde se organiza el contenido de la exhibición.

En el contexto de la institución museo el objeto de colección, en nuestro caso el objeto etnográfico, aparece como el elemento estructurante de la propuesta expositiva. Constituye el primer elemento identitario de la institución a la vez que cubre la expectativa primaria de los visitantes. Pero, no debemos olvidar que su significación estará ligada necesariamente al contex to inmediato y secuencial propuesto.

Dadas las dimensiones y estructura arquitectónica, existen restricciones estructurales. Se trata de una sala con un único ingreso y de forma rectangular. Se encuentra en la planta alta $y$, si bien su recorrido es sugerido con posterioridad a las salas de arqueología, el público toma distintos rumbos desde el acceso central. Sus dimensiones son $27,60 \times 8,00$ metros aproximadamente. 
La organización espacial de la exposición es axial y simétrica. La primera está dada por un eje central delimitado por un conjunto de canoas de tamaño considerable y la simetría se debe a la disposición, a ambos lados de la sala, de vitrinas verticales. Esta organización espacial tiene como consecuencia un recorrido dirigido.

\section{IV.2. Los niveles relacionales desde donde se articula la exhibición}

El contexto de un objeto en una exhibición estará constituido por cada uno y por su despliegue de las entidades icónicas, indiciales y simbólicas perceptibles simultánea o secuencialmente con la percepción del propio objeto.

"En todos los casos se requiere que las disposiciones que aquí se mencionan sean propuestas por alguien o por algunos (como productores de las Semiosis Sustituyente) y sean percibidas por muchos o por algunos o, en caso extremo, por uno (cómo intérprete que construye la Semiosis Sustituida). (...) no existe eficacia semiótica si no es en una situación de comunicación (o sea, no existe eficacia semiótica si no se construye un interpretante en la mente de algún, al menos uno, intérprete)". (Magariños de Morentín, 2008:370).

Estas posibilidades relacionales pueden ser:

- El recorrido de todo el espacio expositivo. El espacio expositivo tiene, como un texto, su propia estructura gramatical. El orden en que se articulan los distintos sectores, unidades temáticas, recursos expositivos, etc. configura un programa narrativo.

- El entorno de los elementos asociados a la mostración del propio objeto Generalmente circunscripto por los límites fijos de la vitrina o estructuras expositivas similares, refiere a las asociaciones materiales y simbólicas en torno a un objeto o conjunto de objetos. Aparecen como unidades temáticas incluidas en el relato/recorrido general.

- La mostración del propio objeto. Se resaltan las cualidades diferenciales del objeto y las unidades temáticas asociadas. Es notoria esta construcción en torno a objetos únicos. 
El primer criterio de organización (ver anexo, plano $n^{\circ} 1$ ) responde a un criterio geográfico. Las dimensiones del espacio expositivo y su forma rectangular, imponen al visitante un recorrido lineal que se inicia temáticamente en Tierra del Fuego y continúa por las distintas regiones de Argentina y países limítrofes hasta el noroeste argentino y la región andina.

En esta distribución se distinguen, según el tratamiento de los temas, dos espacios bien diferenciados: central y periférico. El espacio central está delimitado por la presencia de un conjunto de canoas de distinta procedencia y de un tamaño considerable. A esto se suman pequeños exhibidores en los cuales, siguiendo el orden geográfico se incluyen todas las regiones de Argentina respondiendo a la demanda escolar. Cada región está presentada en leyendas que incluyen mapa de distribución, relato descriptivo, situación actual de los distintos grupos, independientemente de que se cuente con piezas de colección. Cada región está separada de una superficie de apoyo a modo de pupitre de modo que el visitante, particularmente estudiantes, pueda copiar la información. A su vez, pequeños exhibidores muestran piezas representativas. ${ }^{45}$

Dentro de cada región, las vitrinas periféricas están dedicadas a la exhibición de elementos de colección según su procedencia. A su vez, cada una de estas regiones incluye una o dos vitrinas donde los distintos grupos étnicos aparecen representados a través de conjuntos de elementos (cultura material) agrupados según procedencia pero reunidos en el interior de la vitrina según su "afinidad" de uso o significado.

Acerca de las vitrinas y sectores/ relaciones espaciales de disposición de los objetos de colección

Respetando el primer criterio organizativo (geográfico) como unidades de inclusión, se articula un segundo criterio de organización definido a partir de unidades temáticas (ver anexo, plano $\mathrm{n}^{\circ} 2$ ).

Algunas de ellas son: actividades de subsistencia, objetos rituales y fiestas, ornamentos y vestimenta, alimentación, actividades de la mujer, el complejo ecuestre, el carnaval y fiestas andinas, entre otras.

\footnotetext{
${ }^{45}$ La presentación completa del guión museográfico escapa a los intereses específicos de este análisis. El criterio fundamental para definir estos contextos fue el de la etnografía tradicional (descriptiva), atendiendo especialmente a aquellos autores/coleccionistas que describen el específico contexto de recolección del patrimonio aludido.
} 
En el interior de las vitrinas, la disposición de los objetos de colección responde a las siguientes relaciones:

- objetos entre sí: conjunto de objetos involucrados simultáneamente en una misma actividad. Por ejemplo todos los elementos asociados al complejo ecuestre en la cultura araucana.

- objetos únicos: el concepto de único no se limita al conjunto de la colección sino a su presencia en la sala. Por ejemplo, la coraza del cacique Chocorí, la máscara de la Kina o el manto tehuelche.

- objetos del mismo tipo relacionados por diversidad morfológica y cantidad: por ejemplo el conjunto de máscaras del carnaval de la cultura chané, las armas de caza de la cultura del Gran Chaco.

- objetos clasificados dentro del mismo tipo relacionados por similitud y diferencia y según diversidad de procedencia: por ejemplo las canoas del sector central y los instrumentos musicales.

No hay una correspondencia necesaria entre vitrina y tipo de relación. En cada vitrina puede haber más de un tipo de relación entre objetos. A su vez, los distintos contextos están acompañados por textos (semiosis simbólica) y fotografías (semiois icónica). El criterio de selección de las fotografías fue la presencia del/los sujeto/s productor/es desarrollando alguna actividad en su entorno natural. La foto acompaña un texto descriptivo de la actividad y su significado recuperado del contexto socio cultural y según la documentación etnográfica. ${ }^{46}$

La elección de cada criterio de agrupación se orientó según el tipo de piezas, características de la región y la fuerza identitaria de cada tema según modos de vida diferenciales. A su vez, la agrupación de las piezas permite desarrollar un tipo de texto o leyenda superadora de la nomencladora tradicional que minimiza la información a la referencia de un único objeto.

\footnotetext{
${ }^{46}$ Magariños de Morentín propone el término "contexto" para designar el ámbito en el que existen y adquieren o reproducen su significación los fenómenos simbólicos. Propone "configuración" para designar el ámbito en el que existen y adquieren o reproducen su significación los fenómenos icónicos. Y "disposición” para designar el ámbito en el que existen y adquieren o reproducen su significación los fenómenos indiciales (Magariños de Morentín, 2008:368).
} 


\section{3. Acerca de los conceptos rectores}

El recorrido secuencial y la organización geográfica y temática descripta hasta aquí, está atravesada, a su vez, por un tercer criterio organizativo al cual le adjudicamos un carácter transcultural/teórico (ver anexo, plano $\mathrm{n}^{\circ} 3$ ).

Los indicadores de cada sector se hacen explícitos según el recurso expositivo utilizado, el tipo de leyenda y un tratamiento temático que pertenece a un tipo lógico más abarcativo que la cultura particular. Se busca involucrar al visitante de modo de "superar" la situación reduccionista y de ajenidad que acompañan las exhibiciones de este tipo. Estos sectores, si bien respetan la organización geográfica, constituyen rupturas, tanto en sentido conceptual como perceptual. Pretenden provocar un cambio de actitud por parte del visitante. Este incluye: Sector ingreso-Chocorí/ sector máscaras/ sector de la tierra al territorio/ video y mapas/ sector escenario-cierre.

Permite la reflexión más allá de los contextos particulares en que se inscribe el tema de modo de acceder a conceptos teóricos, traducidos a un lenguaje accesible. Se diluye el referente de un único objeto o contexto étnico para hablar de un ámbito de la cultura o de un concepto teórico de la antropología.

En general estos sectores se encuentran acompañados o en algún caso se definen a partir del uso de macrotextos, ubicados en lugares estratégicos fuera de vitrina e instalados en grandes paneles. Por ejemplo, los paneles de ingreso y cierre. Su ubicación y formato gráfico ayudan a la atención del visitante. La relación entre ellos, es vinculante y a la vez independiente, es decir que está propuesto para que el visitante pueda comprender su sentido con cierta independencia del recorrido general.

Este nivel de organización, se encuentra claramente inmerso en un contexto de interpretación de otro orden, ya que se aleja de la información etnográfica que envuelve al objeto. La lógica que subyace a esta matriz alude a sutiles desplazamientos o pasajes de acceso a una mirada actualizada de "los Otros" desde la disciplina antropológica.

Los ejes conceptuales que manifiestan las intenciones de superación respecto del estado anterior de la sala pueden ser enunciados de esta manera: 


\begin{tabular}{|c|c|}
\hline $\begin{array}{l}\text { DESPLAZAMIENTO } \\
\text { CONCEPTUAL } \\
\end{array}$ & $\begin{array}{c}\text { EJEMPLOS DE UNIDADES } \\
\text { TEMÁTICAS } \\
\end{array}$ \\
\hline Del pasado al presente & $\begin{array}{l}\text {-inicios de la antropología/etnografía } \\
\text {-concepto de cultura } \\
\text {-alusión a las primeras recolecciones } \\
\text {-la situación actual de los grupos }\end{array}$ \\
\hline Del objeto al sujeto & $\begin{array}{l}\text {-la dimensión subjetiva de la cultura } \\
\text {-contextos de significación } \\
\text {-aspectos intangibles (mitos, ritos de } \\
\text { pasaje, etc.) }\end{array}$ \\
\hline $\begin{array}{c}\text { Del etnocentrismo a la diversidad } \\
\text { cultural }\end{array}$ & $\begin{array}{c}\text {-concepto de relativismo cultural } \\
\text { - visión del mundo } \\
\text {-diversidad y prejuicio }\end{array}$ \\
\hline De la tierra al territorio & $\begin{array}{c}\text {-concepto de etnía (criterio lingüístico y } \\
\text { territorial) } \\
\text {-el valor de la tierra } \\
\text {-situación actual de los grupos } \\
\text { de Argentina } \\
\end{array}$ \\
\hline De lo local a lo global & $\begin{array}{c}\text {-concepto de identidad } \\
\text {-la etnografía hoy }\end{array}$ \\
\hline De lo lejano (ajenidad) a lo próximo & -la pertenencia, los intercambios \\
\hline
\end{tabular}

Estos criterios organizativos se superponen y entrecruzan en el recorrido de la sala conformando una trama significativa en la cual, cada visitante selecciona, conecta e interpreta múltiples mensajes.

Si bien durante el proceso de llevar "la idea al montaje" fueron muchos los momentos en que pudimos detectar cierto "exceso de racionalización”, creemos que fue absolutamente necesario para lograr una coherencia con la totalidad. Las tensiones entre idea $\mathrm{y}$ objeto/recurso ajustan $\mathrm{y}$ restringen las pretensiones y las modalidades comunicativas adoptadas, pero sin dejar de lado la idea central que una vez aceptada debe ser cuidada de modo que no se genere contradicción.

Se va conformando así una verdadera matriz conceptual o red desde la cual se realizan las elecciones y toma de decisiones, incluso aquella que pareciera insignificante 
o muy lejana a la idea principal. Cada elección material y práctica (altura, color, distancia) tenderá, en distinta medida a reforzar el mensaje ya que el espacio expositivo es a la vez simple y complejo. Simple en el sentido de encontrar una canalización concreta y accesible de los mensajes para un público diverso, y complejo por la superposición e interconexión entre los diferentes niveles del entramado conceptual.

Este nivel comunicacional se toca fuertemente con lo que podríamos concebir como ideología, por el contenido de sus proposiciones, en tanto obliga a los curadores a "tomar posición" respecto del tema tratado. Son el conjunto de ideas que promueven el debate al interior de la disciplina. Aquí los curadores asumen un mayor compromiso dado el carácter de su contenido. Es el nivel de mayor ambigüedad y abstracción respecto del objeto. El patrimonio se transforma en la "excusa" para pensar temas que habitualmente estaban ausentes en el viejo modelo expositivo. Traducido a un formato accesible, abren un campo de reflexión para el observador-visitante. Seguramente, y de forma diferencial, atraviesan algún aspecto de la vida cotidiana, de su propia experiencia de vida, lo involucran emocionalmente generando actitudes tanto positivas como negativas, de rechazo o aceptación y todas las modalidades intermedias entre estos polos. Por otro lado, las rupturas provocan un cambio de actitud. El visitante se detiene, generalmente lee, cambia su gestualidad, aumenta su atención, surgen la curiosidad, la duda.

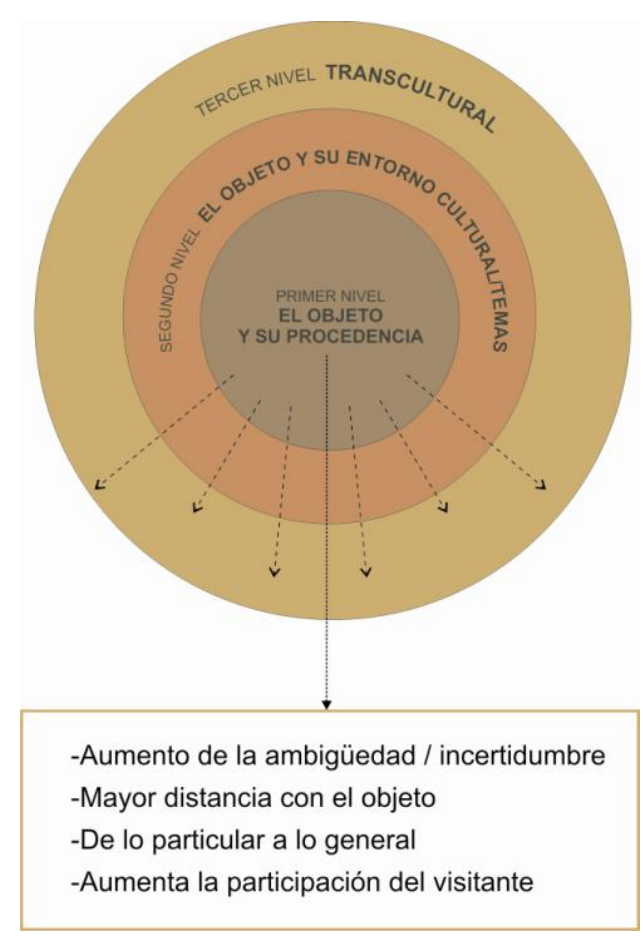




\section{IV.4. Los recursos expositivos}

\section{IV.4.1. Jerarquización de los textos}

La elaboración de los textos de exposición implica la adecuación del lenguaje científico y técnico transformándolo en una leyenda comprensible, que a su vez incorpore elementos de la poética. ${ }^{47}$

Podemos reconocer en la exhibición los siguientes niveles de texto (ver ej. en anexo):

Descriptivo referencial: es un nivel descriptivo que toma como referencia la etnografía clásica. Son los textos que acompañan cada objeto o conjunto de objetos. Es el significado denotado. Generalmente están acompañados de fotografías. Se establecen relaciones contextuales del objeto o entre objetos a partir de la referencia al uso, función, costumbres, técnicas de confección, entre otras.

Ejemplo: Manos y arcilla (referido a la elaboración de la cerámica chiriguana) (Ver anexo)

Particularista e histórico: describe las costumbres y grupos étnicos de cada región. Alude a la historia, el medio ambiente, e identifica aquellas características propias de una región. Hace referencia a la situación actual de los grupos y tiene como soporte el criterio geográfico, lingüístico y cultural. Ejemplo: Texto que acompaña la armadura del cacique Chocorí (ver anexo).

Sistemático cultural: aluden a diferentes ámbitos de la cultura. El enmascaramiento, el mito, las fiestas, la alimentación, el complejo ecuestre, el valor de la tierra, entre otros. Ejemplo: Máscaras y enmascaramieto (ver anexo) Supera los límites de una cultura en particular e incorpora elementos connotados.

Teórico-disciplinar: incorpora la mirada sobre la cultura desde la antropología. Los ejemplos de textos de este tipo son sobre el concepto de identidad, la tarea del etnógrafo, la diversidad cultural. Generalmente forman parte del inicio y del cierre de la exposición. Si bien se sustentan en un concepto teórico disciplinar, incorpora en su forma elementos connotados e incluso de estilo poético.

\footnotetext{
${ }^{47} \mathrm{La}$ "traducción" del lenguaje científico a un lenguaje de divulgación conlleva un conjunto de técnicas y requisitos. No nos referiremos en este trabajo a la estructura del texto sino a la intención de su producción. De allí que su jerarquización se referirá a los niveles de abstracción y ambigüedad en relación al objeto de colección como referente.
} 
Esta suerte de clasificación presenta límites difusos. Las categorías no son necesariamente excluyentes sino que deben verse como tendencias en las modalidades de los distintos discursos. Pero, es de mayor importancia reconocer las relaciones con el objeto de colección y las intenciones de cierta provocación hacia el visitante, expresada en términos de "invitación". Podríamos decir que progresivamente cada categoría se aleja de una estructura referencial denotada hacia la incorporación de elementos de mayor connotación. ${ }^{48}$

Resulta pertinente para dar cuenta de este recurso la distinción que hace Umberto Eco entre proposiciones de función referencial y de función sugestiva. "Sabemos que un mensaje lingüístico puede aspirar a diferentes funciones: referencial, emotiva, conativa (o imperativa), fática (o de contacto), estética o metalingüística. Sin embargo, una distribución de este género presupone una conciencia articulada de la estructura del lenguaje y (como se ve) presupone que se sepa qué distingue la función estética de las demás. (...) preferimos referirnos a una dicotomía puesta de moda hace unos cuantos decenios por los estudiosos de la semántica: la distinción entre mensajes de función referencial (el mensaje indica algo unívocamente definido $\mathrm{y}$, en caso necesario, verificable) y mensajes de función emotiva (el mensaje mira de suscitar reacciones en el receptor, de estimular asociaciones, de promover comportamientos de respuesta que vayan más allá del simple reconocimiento de la cosa indicada).”(Eco, 1992:111).

De esta dicotomía se desprende la función referencial y la sugestiva asociada al mensaje emotivo. Esta última incorpora elementos connotados pero principalmente deja un espacio al lector/intérprete, encargado de incorporar la cuota de referencialidad desde su propia percepción/experiencia. El sujeto intérprete nunca es ajeno a su interpretación.

“Cada uno, pues, frente a una expresión rigurosamente referencial que exige un esquema de comprensión bastante uniforme, complica no obstante su comprensión con referencias conceptuales o emotivas que personalizan el esquema y le confieren un color

\footnotetext{
48 "Un signo denota una posición en el sistema semántico. El acto de denotación es la referencia a una unidad semántica correspondiente, sobre la base de las reglas de correspondencia fijadas por el código. La denotación es la referencia que se produce en unas circunstancias y en un contexto determinado, aquella posición en el sistema semántico en el que desde el comienzo y de manera potencial, el código hacía que el significado fuera referido."

El significado connotado "refiriéndose a una unidad semántica del sistema, el significante se refiere también a otras unidades de las que la primera es un significante (o un interpretante), aunque sea parcial y generalizado, y que a su vez son significantes de otras unidades. (...) la connotación del sentido lingüístico se define, por lo tanto como la referencia en cadena de unidad cultural en unidad cultural." (Eco, 1994:182).
} 
particular. Sin embargo, es un hecho que, por muchos resultados "pragmáticos" que estas distintas comprensiones den, quien quiera reducir la comprensión de varios oyentes a un Pattern unitario con el fin de controlarla, puede hacerlo fácilmente." (Eco, 1992:113). Por otro lado, la función sugestiva es más difusa y "la reacción imprecisa del oyente no es accidental respecto de su comunicación; constituye, por el contrario, el efecto deseado. (...) Quien comunica siguiendo esta intención sabe asimismo que el halo connotativo de un oyente no será igual al de otros eventualmente presentes, pero, escogiéndolos en idénticas condiciones psicológicas y culturales, pretende precisamente organizar una comunicación de efecto indefinido $-\mathrm{y}$, además, delimitado- según lo que podemos llamar un "campo de sugerencia.” (Eco, 1992:116).

En la sala referente de análisis los textos clasificados como de carácter sistemático cultural y teórico disciplinar toman la forma de macrotextos. Estos permiten abordar un tema más allá de un grupo particular. En general, adoptan otra forma discursiva, más interpretativa, generalizable, en algún caso poético y, por lo tanto ambiguo. Cumplen la función de generar rupturas en el recorrido de modo de organizar las distintas unidades temáticas. Generalmente forman parte del ingreso y cierre de sala o acompañan recursos constituyendo un refuerzo. Ubicados fuera de vitrina, tienen un tratamiento gráfico diferente.

Si bien es posible sistematizar esta presentación exhibición y los recursos utilizados, prevalece cierta transversalidad de los discursos.

A partir de cierto orden que identifica un tendencia tales como el nivel de generalidad (particular/universal), lenguaje (descriptivo/interpretativo/poético), referencia temporal (pasado /presente) y referencia espacial (local/global)- los diferentes niveles se superponen, sustituyen y desplazan funcionando como un hipertexto (o red conceptual) con grandes nudos o nodos de conexión.

\section{IV.4.2. Gráficos / mapas}

Cada región de la Argentina y su caracterización cultural están presentadas en una gráfica compuesta con un mapa actualizado, fotos y la descripción general de los grupos étnicos de la región. Este nivel de información se encuentra concentrado espacialmente en el centro de la exhibición y acompañado de espacios que, haciendo las veces de pupitre, pueden ser utilizados por escolares para copiar la información. 
Mantienen un formato estandarizado de manera de favorecer su identificación y refuerzo.

Una vez concluido el recorrido de por regiones la información se sintetiza en un único mapa que puede ser comparado con otro que presenta la distribución en el territorio Argentino en el siglo XVI. El texto alude a la concepción por parte de estos grupos vinculada a la tierra y su reclamo actual fortalecido por la transcripción de la ley de devolución de las tierras. ${ }^{49}$

\section{IV.4.3. Fotografías}

Las fotografías constituyen otro de los recursos utilizados para pasar del objeto al sujeto. Fueron seleccionadas con la intención de mostrar a los sujetos realizando actividades en su ambiente natural.

\section{IV.4.4. Recurso multimedia}

En este caso se editó un video que tiene como objetivo fortalecer un concepto dinámico de cultura. Se centra en la presencia de individuos de diversos grupos en su ambiente natural, siendo posible establecer relaciones con objetos exhibidos en las vitrinas. No tiene carácter instructivo, es decir, no está organizado en una secuencia fija que imponga al visitante la atención constante, sino que lo acompaña en el recorrido. El visitante puede apreciar la propuesta en cualquier momento del desarrollo del guión.

\section{IV.4.5. Puestas escenográficas}

El escenario final de la sala etnografía conjuga una serie de objetos conocidos que promueven en el visitante asociaciones libres. El conjunto de objetos elegidos apunta a inhibir al visitante de identificar una región particular de Argentina. Entre ellos se encuentran elementos artesanales (manta) junto a objetos cotidianos (mate/ radio) y

\footnotetext{
${ }^{49}$ En Argentina, con la reforma de 1994, se introdujeron en la Constitución Nacional modificaciones que atienden las aspiraciones reivindicativas y reclamos formulados en diversos foros.

Art. 75. Inc. 17:"Reconocer la preexistencia étnica y cultural de los pueblos indígenas argentinos. Garantizar el respeto a su identidad y el derecho a una educación bilingüe e intercultural; reconocer la personería jurídica de sus comunidades, y la posesión y propiedad comunitarias de las tierras que tradicionalmente ocupan; y regular la entrega de otras aptas y suficientes para el desarrollo humano; ninguna de ellas será enajenable, transmisible ni susceptible de gravámenes o embargos. Asegurar su participación en la gestión referida a sus recursos naturales y a los demás intereses que los afecten. Las provincias pueden ejercer concurrentemente estas atribuciones."
} 
figuras emblemáticas (foto de Maradona). Con esta combinación se busca superar la interpretación de lo regional y lejano para que el visitante pueda establecer relaciones con su mundo cotidiano. A su vez, estos mensajes tienen como refuerzo un fragmento del escritor Eduardo Galeano que alude a la identidad y los museos. ${ }^{50}$

\section{IV.4.6. Interactivos}

El concepto de interacción designa tanto a aspectos cognitivos, emocionales y lúdicos. El sector de las máscaras propone al visitante "verse viendo". A través de un panel, se lo invita a "espiar" hacia el otro lado para lo cual indefectiblemente debe "enmascararse". Para observar, el visitante debe apoyar la cara en una máscara de procedencia chané (región chaqueña) característica del carnaval que se encuentra formando parte de una foto que muestra una escena del carnaval, a escala 1:1. Pero el único modo de ver esto es "asomándose" a través de la máscara a un espacio que, por medio de un espejo, proyecta el entorno del enmascarado. Así, los ojos que miran a través de la máscara son los del visitante que se observa a sí mismo enmascarado. Incorpora elementos lúdicos generando curiosidad, sorpresa, risa.

\section{IV.4.7. Objetos emblemáticos}

Los objetos emblemáticos son aquellos que ostentan un valor agregado por su historia dentro de la institución $\mathrm{y}$, a su vez por ocupar un lugar particular como significante de otras temáticas asociadas.

En nuestro caso, la coraza el cacique Chocorí y su asociación con el maniquí que ha sido su soporte desde las primeras décadas del museo, ostenta una fuerza particular como disparador de una historia particular que se acopla a otra regional de los pueblos del sur y a la historia argentina. A su vez, el maniquí contrasta con las nuevas formas expositivas más abstractas respondiendo a una expresión realista de la mirada occidental sobre "el otro" de fines del siglo XIX y principios del XX. Es, en la sala, el primer punto de atracción, invita a su ingreso.

\footnotetext{
${ }^{50}$ Cada promesa es una amenaza; de cada pérdida, un encuentro. De los miedos nacen los corajes; y de las dudas, las certezas. Los sueños anuncian otra realidad posible y los delirios, otra razón. Al fin y al cabo, somos lo que hacemos para cambiar lo que somos. La identidad no es una pieza de museo, quietecita en la vitrina, sino la siempre asombrosa síntesis de las contradicciones nuestras de cada día. ... Eduardo Galeano, El libro de los abrazos.
} 


\section{IV.5. Relaciones de producción}

El objetivo de describir en forma detallada los diversos recursos empleados en la sala de exhibición es el de dar cuenta del contexto comunicativo en que se desarrolla la experiencia de la visita. A su vez, se busca explicitar los criterios por los cuales se "adhiere" cierta intención a cada recurso. Esta instancia permitirá, a posteriori, establecer relaciones entre la sala, concebida como contexto de re-presentación y los discursos producidos por los visitantes luego de la experiencia de la visita, el contexto de apropiación. Así es posible recuperar el lugar de anclaje en la construcción de sentido. Es decir, a través del análisis de los discursos producidos, recuperar los mundos semióticos posibles disponibles en una comunidad dada y en un momento dado para una concreta situación comunicativa. Es en este punto donde la investigación ingresa fuertemente en el campo de la pragmática, según van Dijk.

Dado que para la semántica hemos trabajado con una reconstrucción abstracta muy útil de la realidad, a saber, con el concepto de "mundos posibles", también aquí queremos introducir una abstracción para el término "situación comunicativa", el concepto contexto. Así pues, la pragmática se ocupa de las condiciones y reglas para la idoneidad de enunciados (o actos de habla) para un contexto determinado; resumiendo: la pragmática estudia las relaciones entre texto y contexto. Es decir, se ocupa, de la relación entre la estructura textual y los elementos de la situación comunicativa sistemáticamente ligados a ella: todos estos elementos juntos forman el contexto (van Dijk, 1983).

"El concepto de "contexto" se caracteriza como la reconstrucción teórica de una serie de rasgos de una situación comunicativa, a saber, de aquellos rasgos que son parte integrante de las condiciones que hacen que los enunciados den resultados como actos de habla. El objetivo de la pragmática es formular estas condiciones, es decir: indicar qué vinculación existe entre los enunciados y este contexto. Y puesto que describimos los enunciados teóricamente como textos, se trata aquí de la especificación de las relaciones entre texto y contexto. Estas relaciones se extienden en ambas direcciones: por un lado, ciertos rasgos textuales pueden "expresar" o incluso constituir aspectos del contexto, y por otro, la estructura del contexto determina, hasta cierto grado, de qué rasgos deben disponer los textos para ser aceptables -como enunciado- en el contexto. “(van Dijk, 1983:91). 
"Hay una serie de relaciones entre la oración (texto) y el contexto que aún se adscriben al campo de la semántica, la semántica contextual, a saber, las expresiones indiciales. Se trata de expresiones que remiten a componentes del contexto comunicativo (a él le deben su interpretación), por ejemplo: hablante, oyente, momento de la manifestación, lugar, etc. Esto significa que estas expresiones tienen cada vez un referente distinto según el contexto (cambiante)." (van Dijk, 1983:93).

La visita a una sala de exhibición es una experiencia situada, acotada en tiempo y espacio. Una experiencia de la que resulta en poco tiempo una acabada síntesis cognitiva por parte del visitante.

El presente cuadro pretende sistematizar en algunos ejemplos el cambio conceptual de las principales ideas de la nueva propuesta en relación a los recursos museográficos utilizados y la reflexión asociada propuesta al visitante.

\begin{tabular}{|c|c|c|c|}
\hline Estado anterior & Idea rectora & Algunos recursos & $\begin{array}{c}\text { Reflexión } \\
\text { propuesta al } \\
\text { visitante }\end{array}$ \\
\hline $\begin{array}{c}\text { - lo indígena o } \\
\text { aborigen asociado } \\
\text { al pasado }\end{array}$ & $\begin{array}{l}\text { - la situación } \\
\text { actual de los } \\
\text { pueblos } \\
\text { originarios de } \\
\text { Argentina }\end{array}$ & $\begin{array}{l}\text { - distribución de grupos a } \\
\text { través de mapas } \\
\text { comparativos. } \\
\text { - video de diferentes grupos } \\
\text { - datos estadísticos de } \\
\text { población actual }\end{array}$ & $\begin{array}{l}\text { Sobre la relación } \\
\text { pasado - presente }\end{array}$ \\
\hline $\begin{array}{c}\text { - un concepto de } \\
\text { identidad } \\
\text { esencialista }\end{array}$ & $\begin{array}{l}\text { - un concepto } \\
\text { de identidad } \\
\text { constructivista y } \\
\text { relacional. }\end{array}$ & $\begin{array}{c}\text { - escenografía con } \\
\text { diversidad de objetos } \\
\text { - macrotextos identidad y } \\
\text { cambio }\end{array}$ & $\begin{array}{l}\text { Sobre la relación } \\
\text { nosotros - otros y la } \\
\text { diversidad cultural }\end{array}$ \\
\hline $\begin{array}{l}\text { - una etnografía } \\
\text { restringida a los } \\
\text { objetos }\end{array}$ & $\begin{array}{l}\text { - la etnografía } \\
\text { como estudio } \\
\text { holístico de la } \\
\text { cultura }\end{array}$ & $\begin{array}{l}\text { - incorporación del mundo } \\
\text { simbólico (relato de mitos- } \\
\text { carácter simbólico de } \\
\text { algunos objetos) }\end{array}$ & $\begin{array}{l}\text { Pasaje del objeto al } \\
\text { sujeto y su } \\
\text { aproximación al } \\
\text { presente }\end{array}$ \\
\hline $\begin{array}{l}\text { - la sala de } \\
\text { exhibición como } \\
\text { una totalidad } \\
\text { representativa de } \\
\text { los "Otros" }\end{array}$ & $\begin{array}{c}\text { - la sala de } \\
\text { exhibición como } \\
\text { una forma } \\
\text { posible de } \\
\text { exponer un } \\
\text { fragmento de la } \\
\text { cultura }\end{array}$ & $\begin{array}{l}\text { - la pregunta ¿qué cosas } \\
\text { pondría en una vitrina de su } \\
\text { mundo cotidiano que nos } \\
\text { cuenten sobre usted? }\end{array}$ & $\begin{array}{l}\text { La presentación } \\
\text { fragmentada de la } \\
\text { cultura }\end{array}$ \\
\hline
\end{tabular}




\begin{tabular}{|c|c|c|c|}
\hline $\begin{array}{c}\text { - La materialidad } \\
\text { del objeto como } \\
\text { representación } \\
\text { cultural }\end{array}$ & $\begin{array}{c}\text {-el contexto } \\
\text { como } \\
\text { construcción de } \\
\text { significados. }\end{array}$ & $\begin{array}{c}\text {-relaciones temáticas entre } \\
\text { objetos }\end{array}$ & $\begin{array}{c}\text { Sobre la relación } \\
\text { hombre - naturaleza. }\end{array}$ \\
\hline $\begin{array}{c}\text { - Un concepto de } \\
\text { cultura estático }\end{array}$ & $\begin{array}{c}\text { Un concepto de } \\
\text { cultura dinámico }\end{array}$ & -construcción escenográfica & $\begin{array}{c}\text {-Acerca del cambio y } \\
\text { los contactos }\end{array}$ \\
\hline $\begin{array}{c}\text { ausencia de } \\
\text { sujetos } \\
\text { productores }\end{array}$ & $\begin{array}{c}\text { - presencia de } \\
\text { sujetos } \\
\text { productores }\end{array}$ & $\begin{array}{c}\text { - transcripción de la ley } \\
\text { sobre la preexistencia de } \\
\text { los pueblos originarios. }\end{array}$ & $\begin{array}{c}\text { la tierra. Los derechos } \\
\text { sobre la tierra. } \\
\text { Procesos históricos. }\end{array}$ \\
\hline
\end{tabular}




\section{Anexos}

1. Planos.

2. Fotos de la sala Etnografía

3. Ejemplos de textos según jerarquización. 


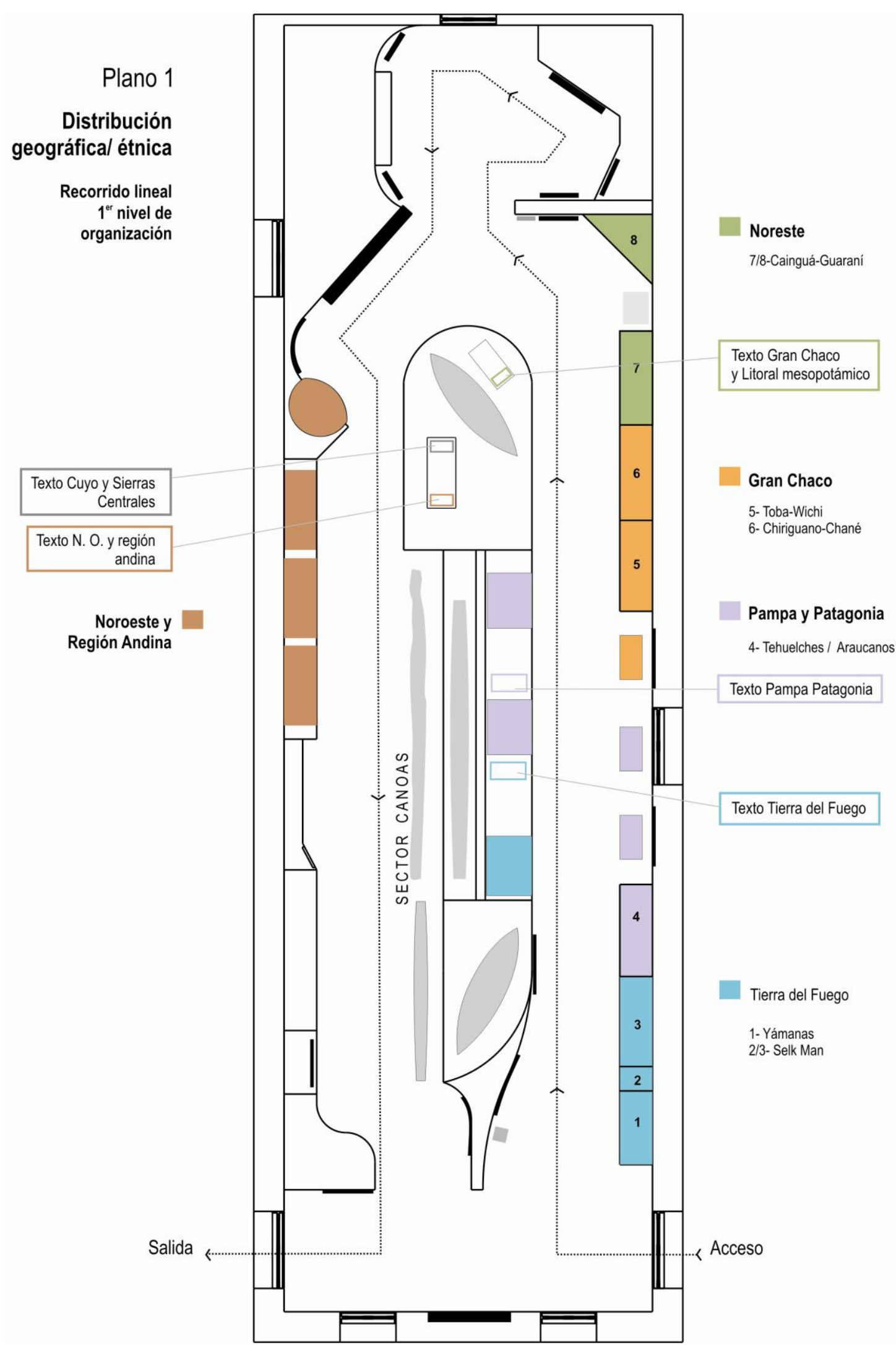




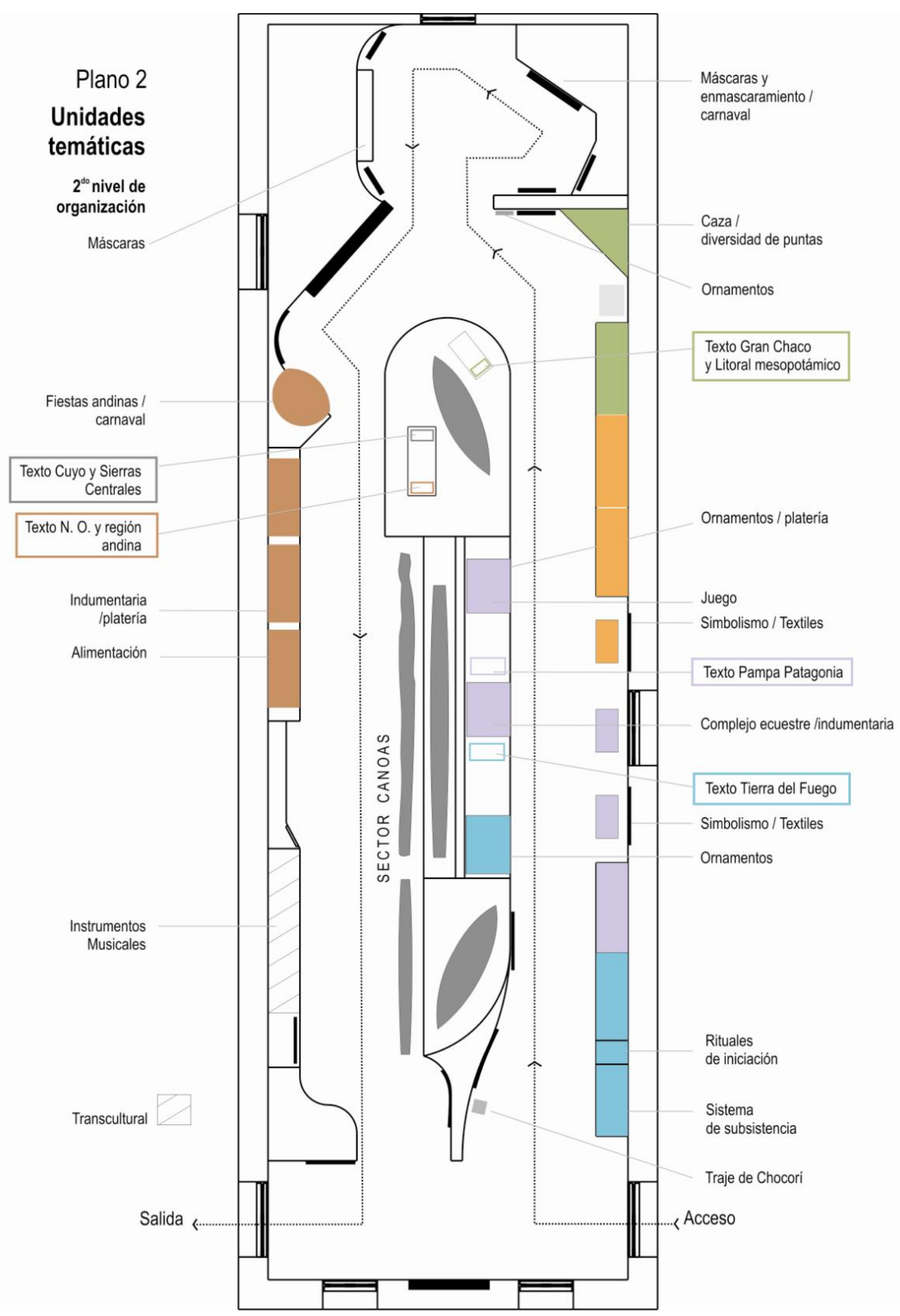




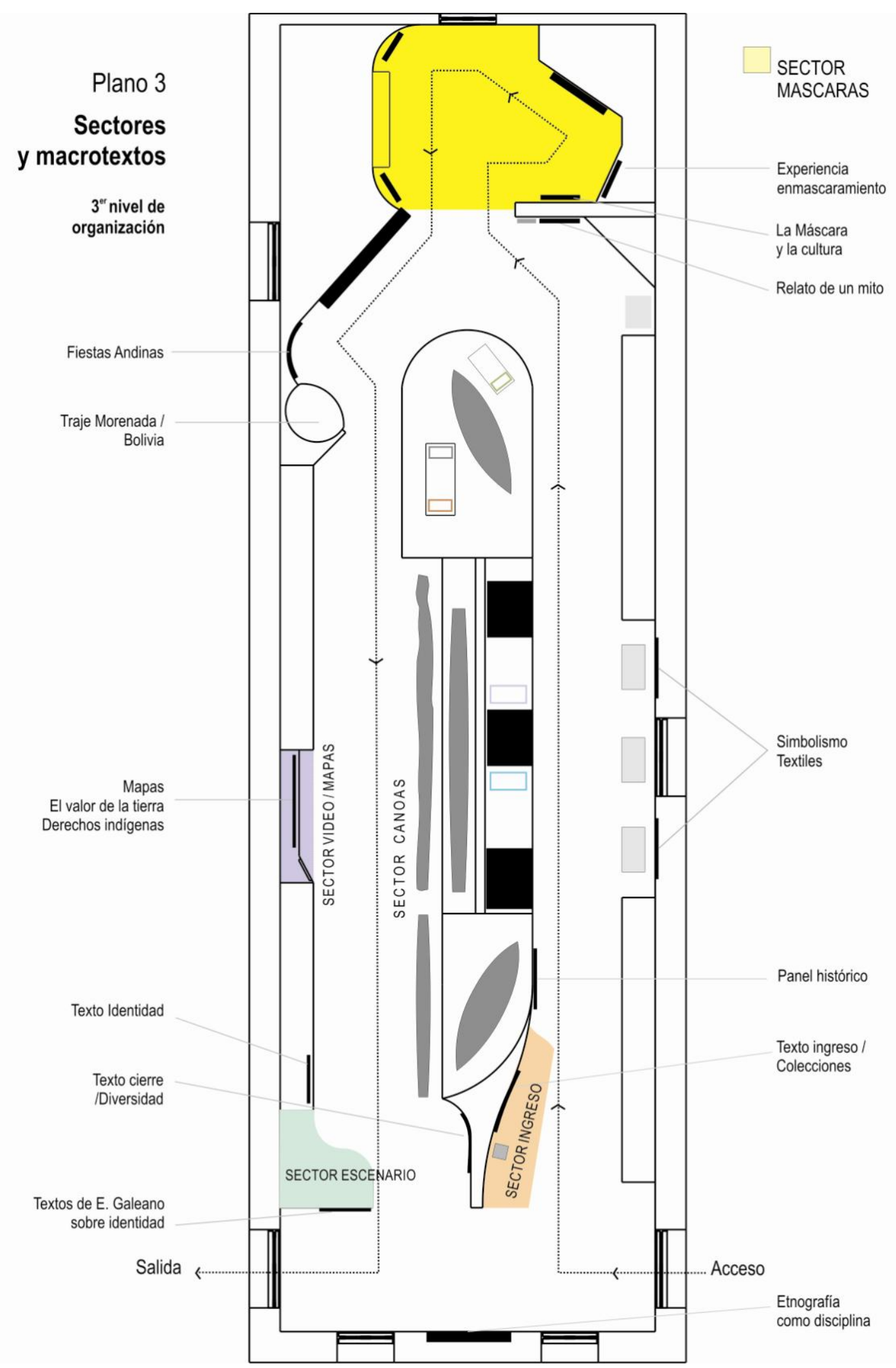




\section{Fotos de la Sala Etnografía}

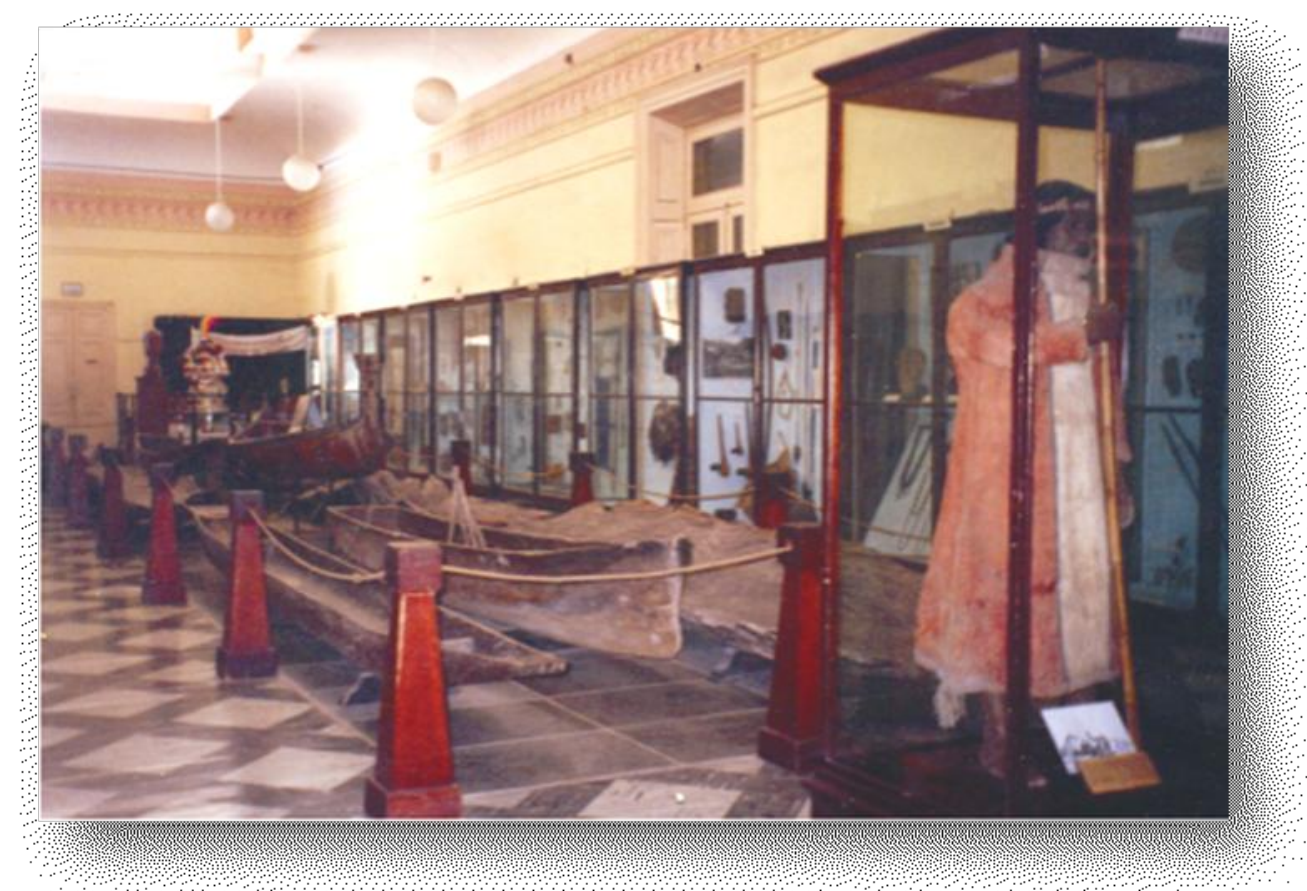

Vistas generales antes de la remodelación

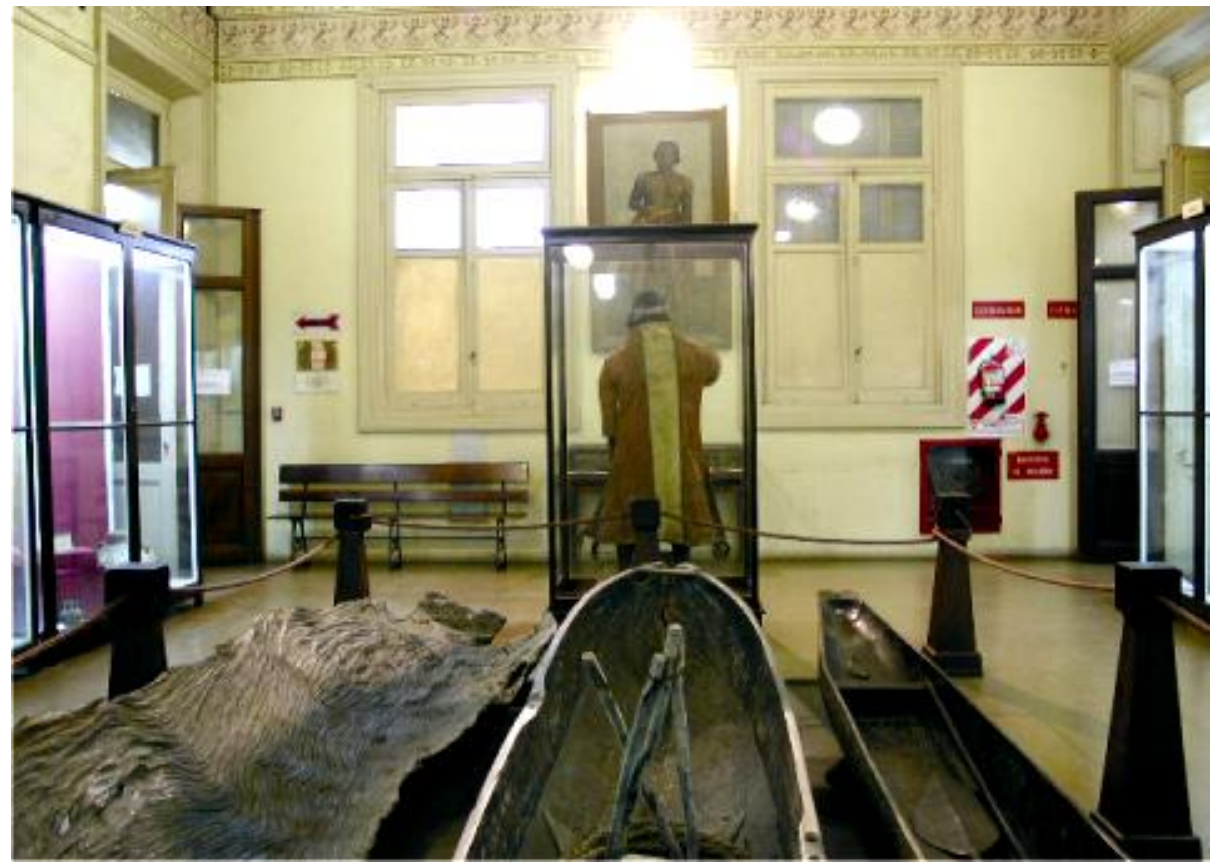




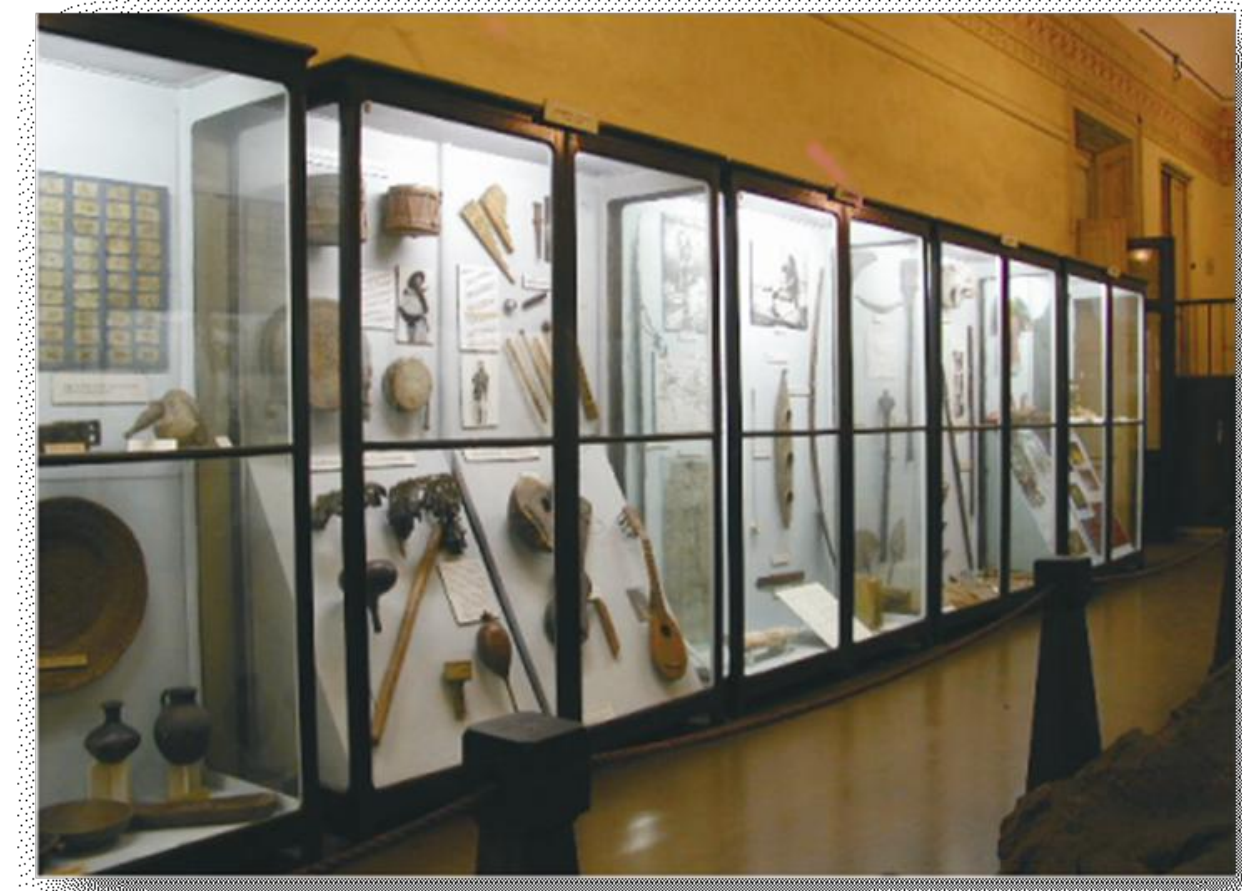

Vistas generales antes de la remodelación

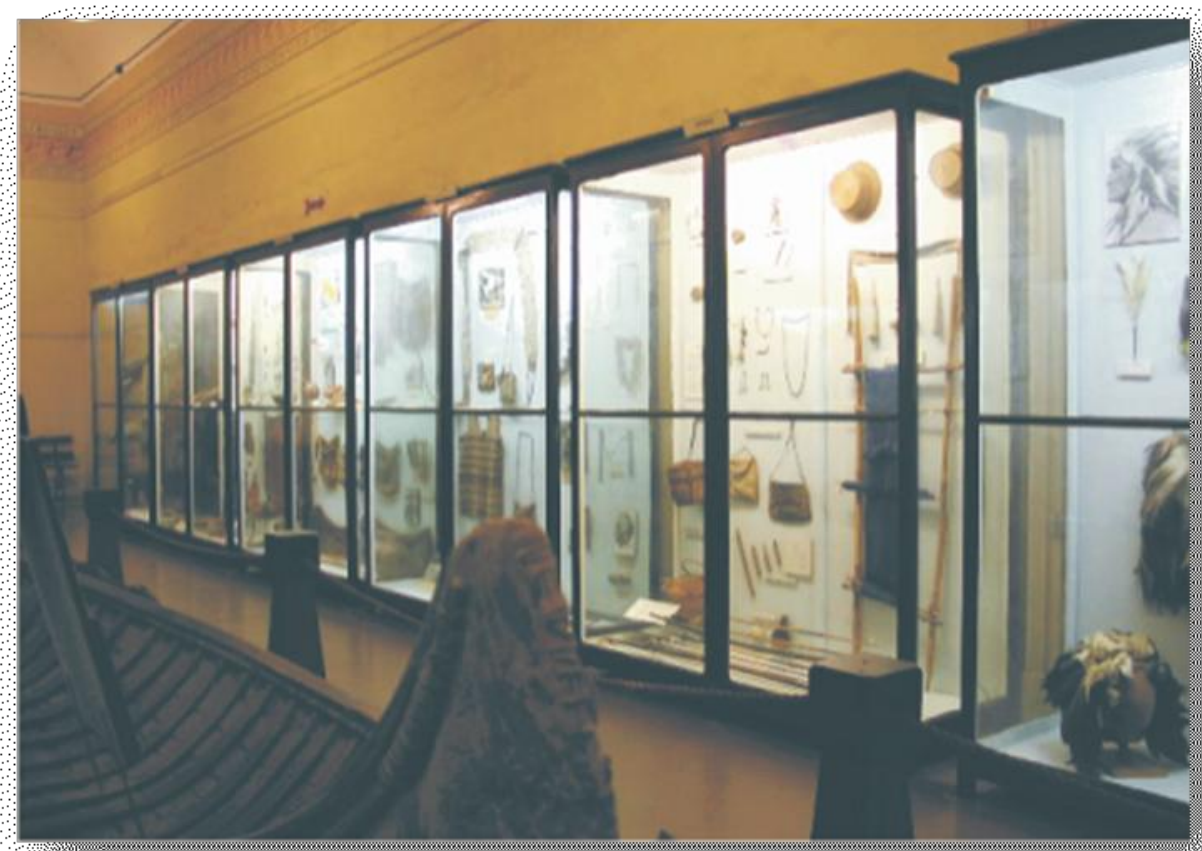


Sala remodelada: ESPEJOS CULTURALES

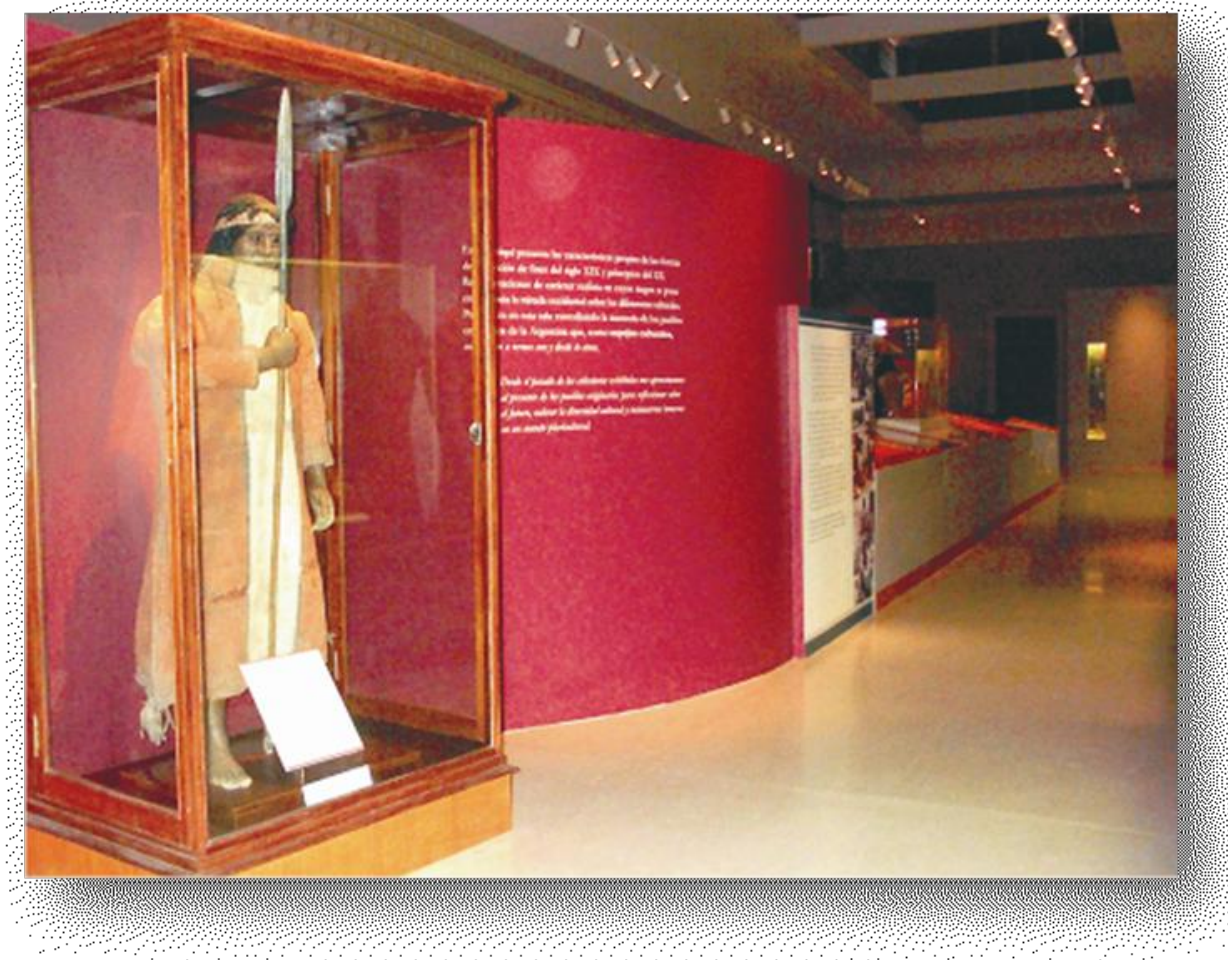

Foto $N^{o} 1$-Sector Ingreso / Traje perteneciente al Cacique Chocorí.

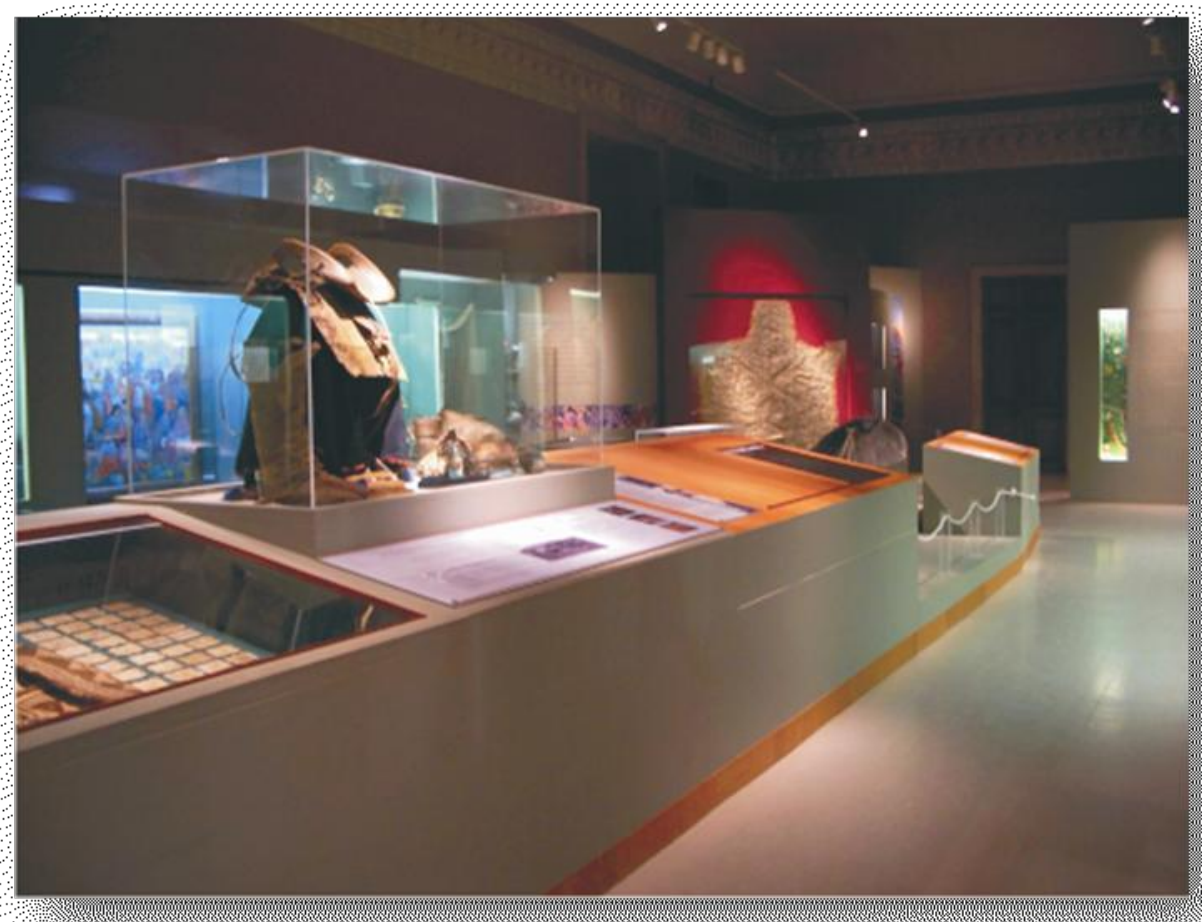

Foto $N^{o} 2$ - Sector Pampa y Patagonia / Complejo ecuestre 


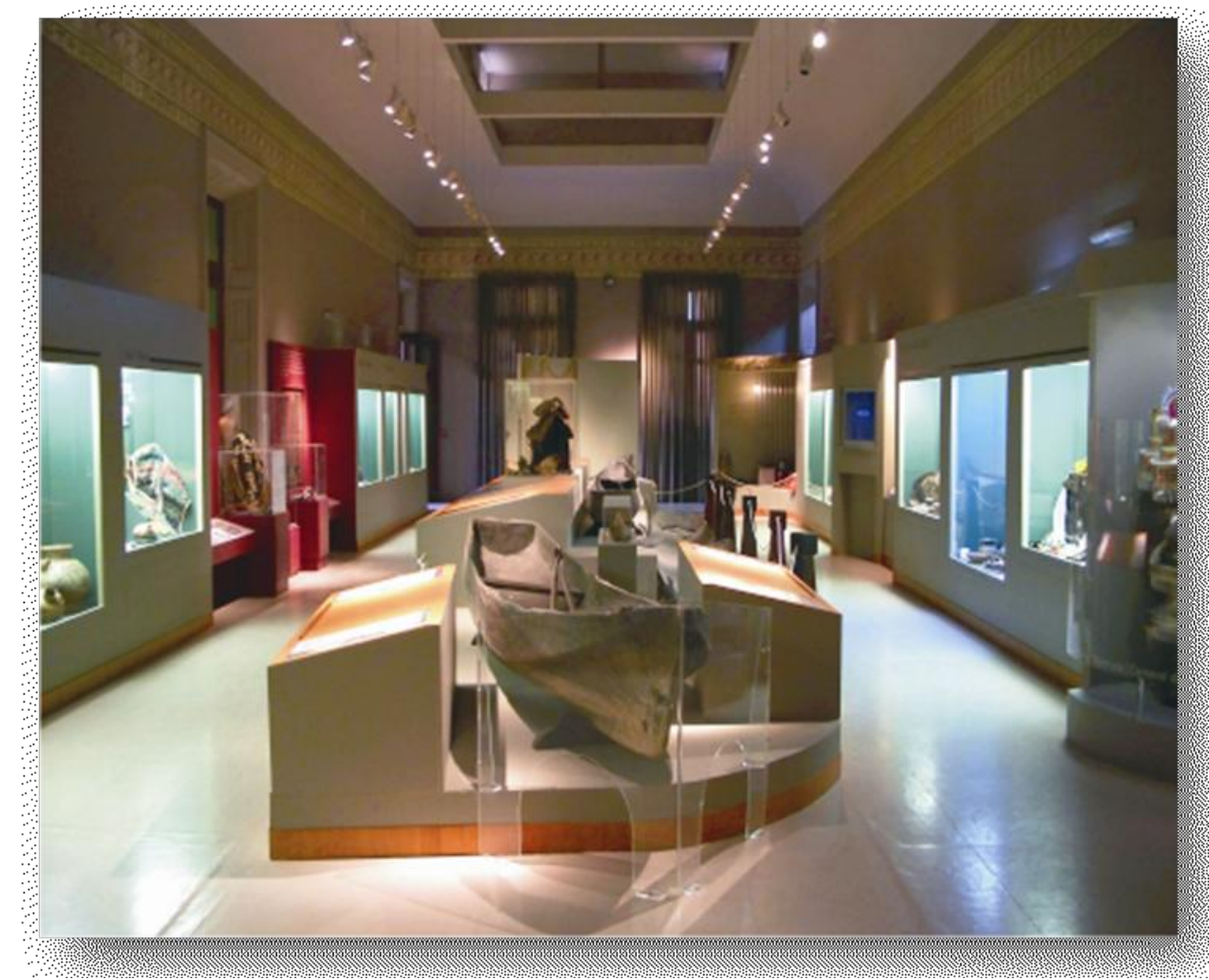

Foto $N^{o} 3$ - Vista general.

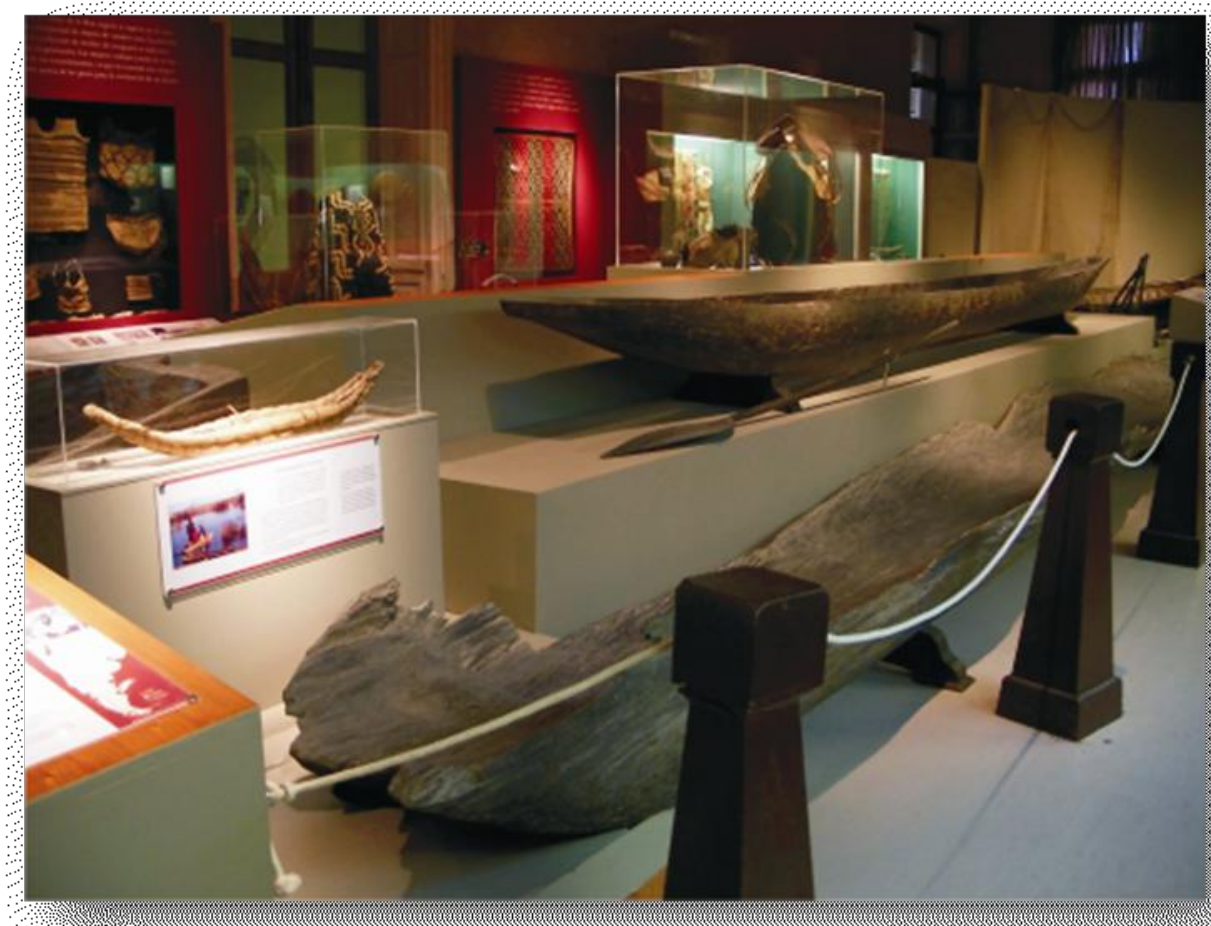

Foto $N^{o} 4$ - Sector Central / Canoas 


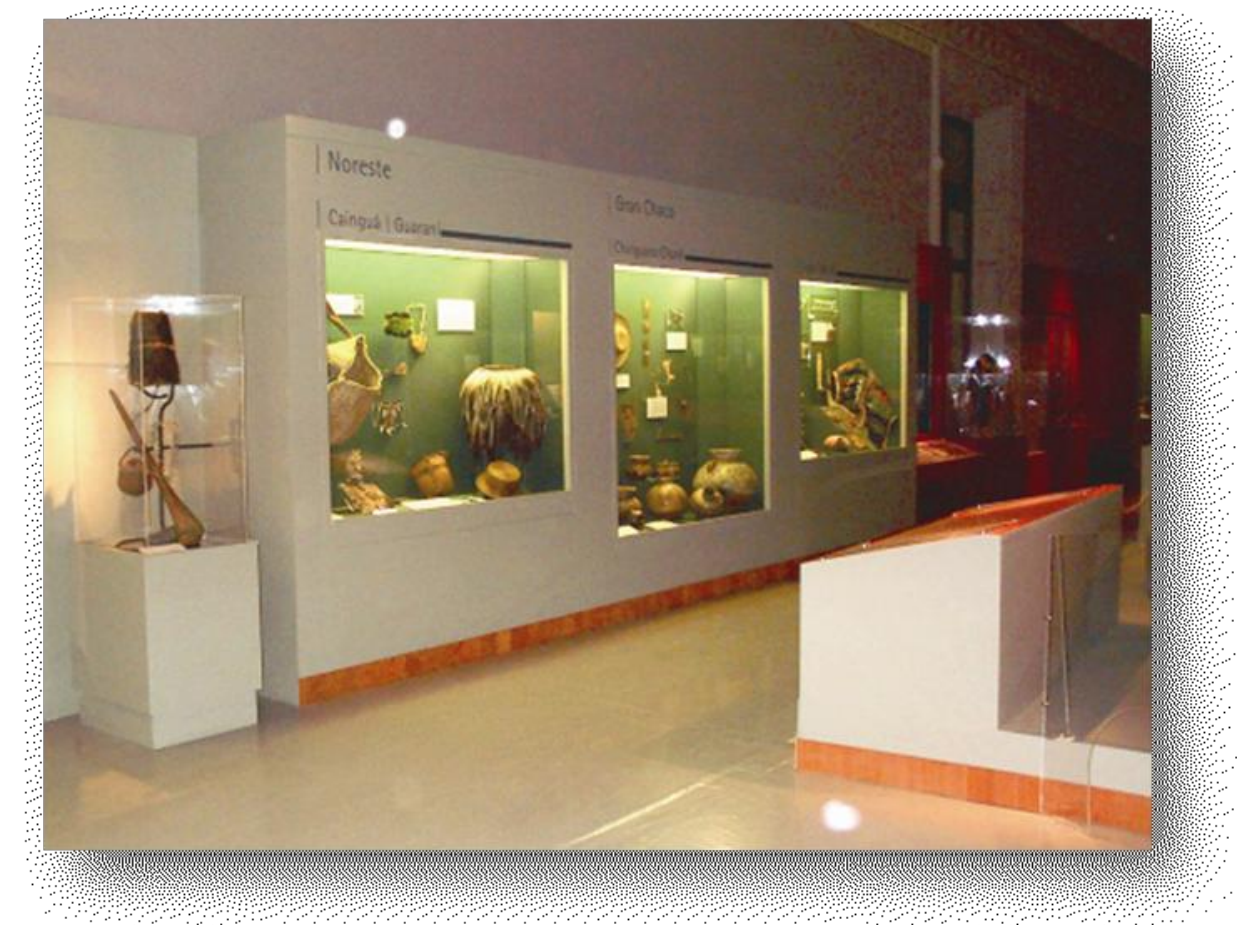

Foto $N^{o} 5$ - Sector Gran Chaco y Noreste

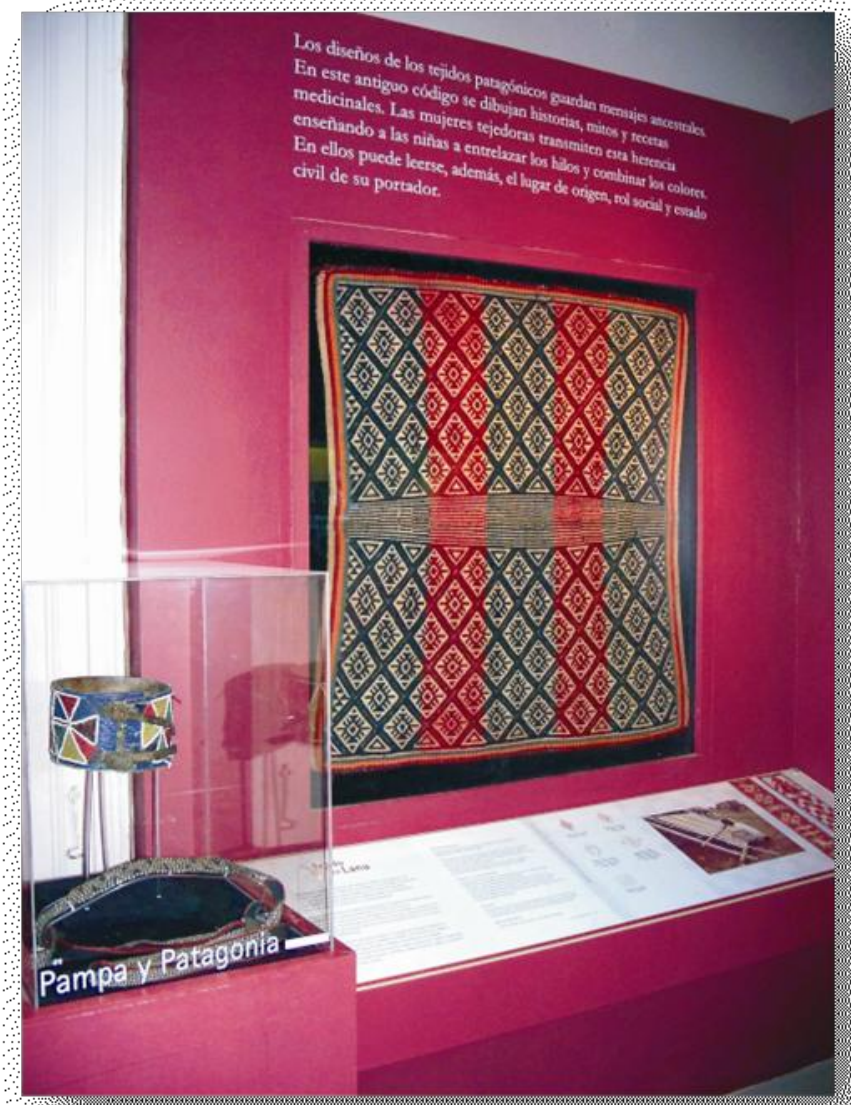

Foto $N^{o} 6$ - Sector Pampa y

Patagonia / Vitrina Textiles 


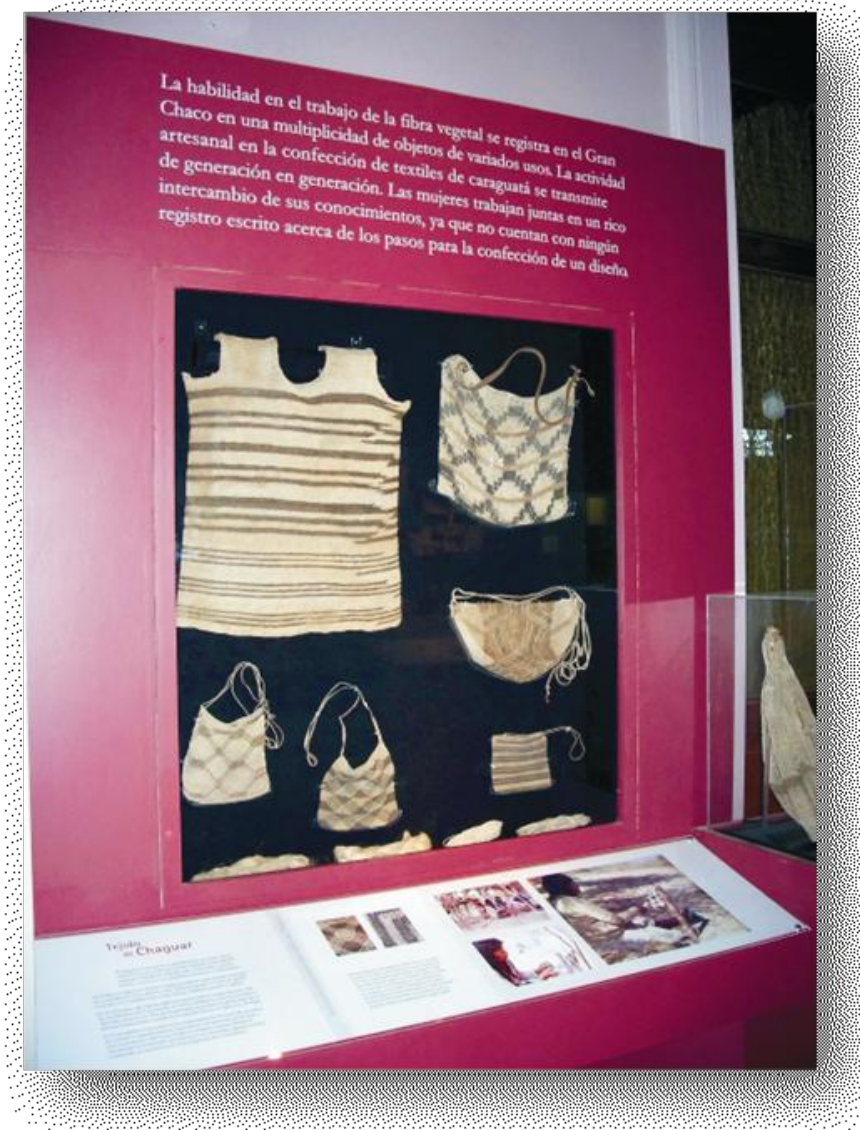

Foto $N^{\circ} 7$ - Sector Gran

Chaco /Vitrina Textiles

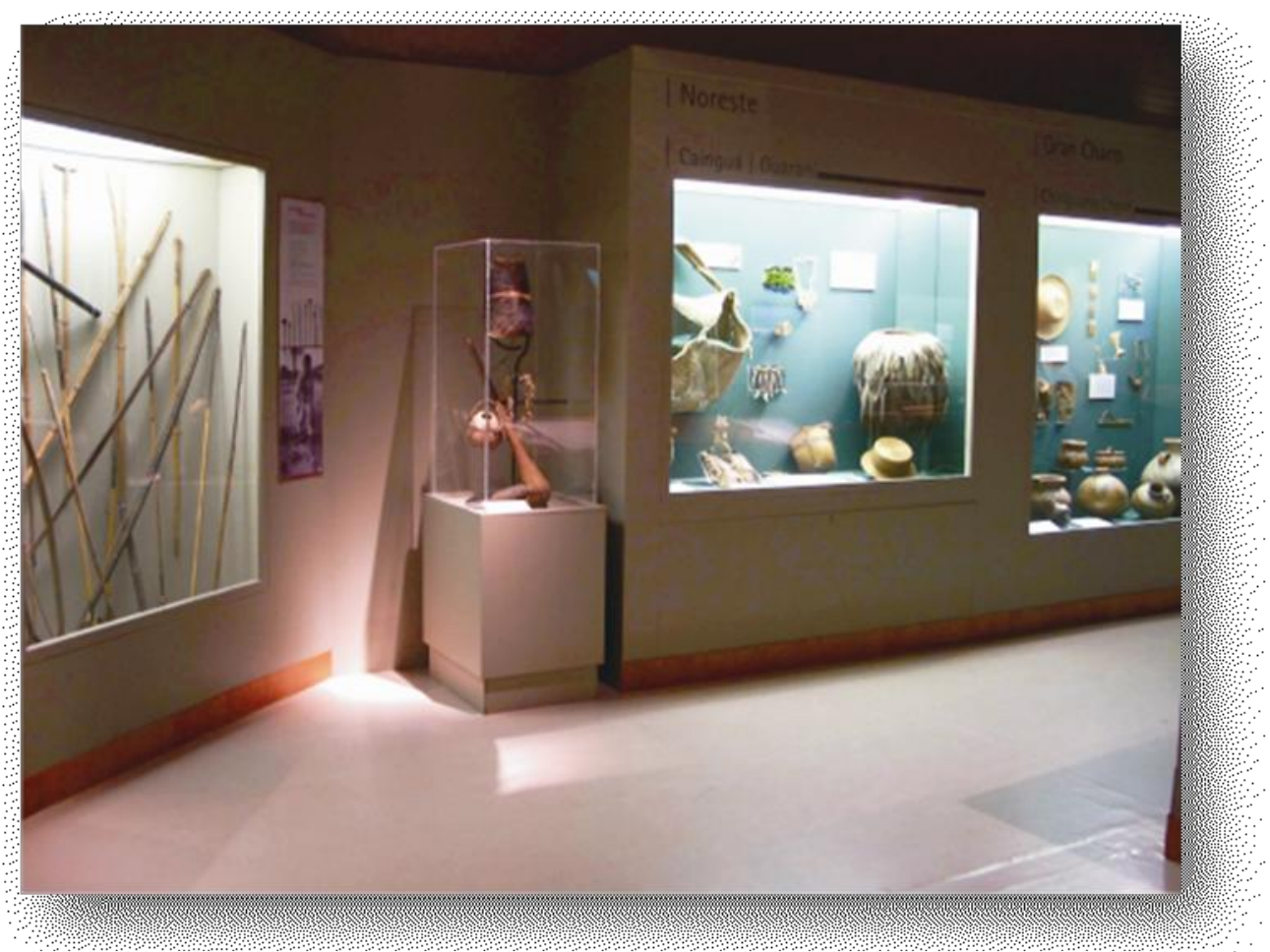

Foto $N^{o} 8$ - Sector Gran Chaco 


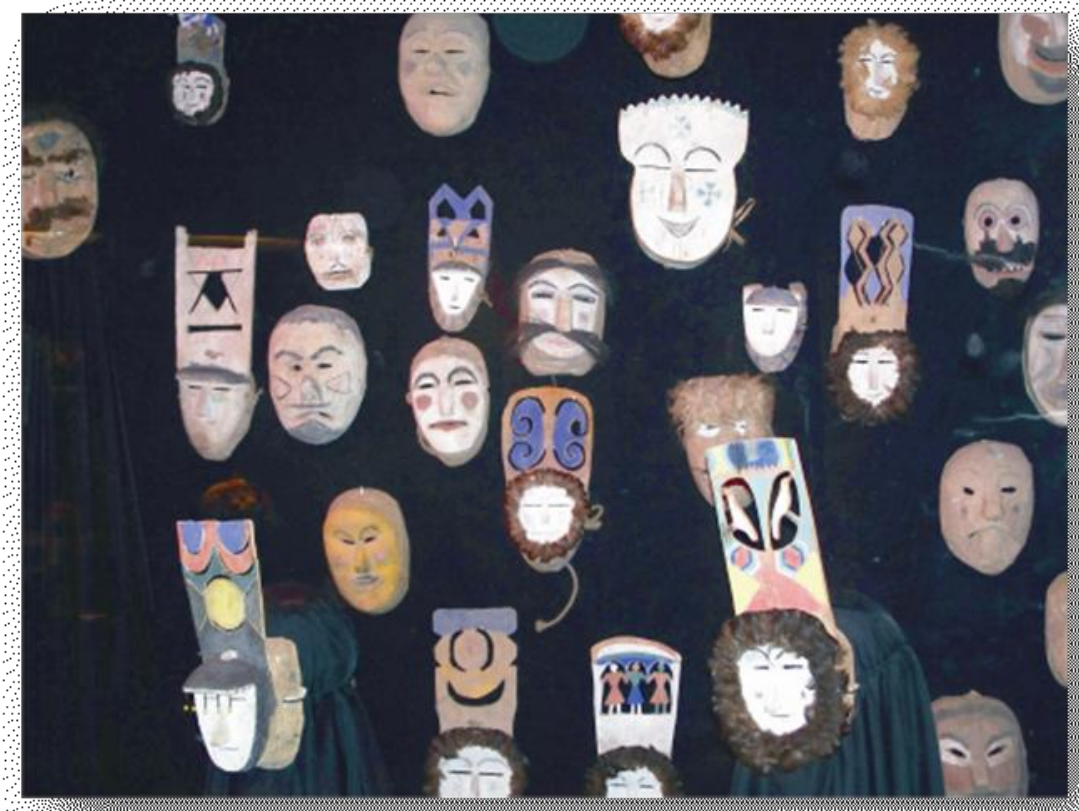

Foto $N^{\circ} 9$-Sector Máscaras / Chaco salteño

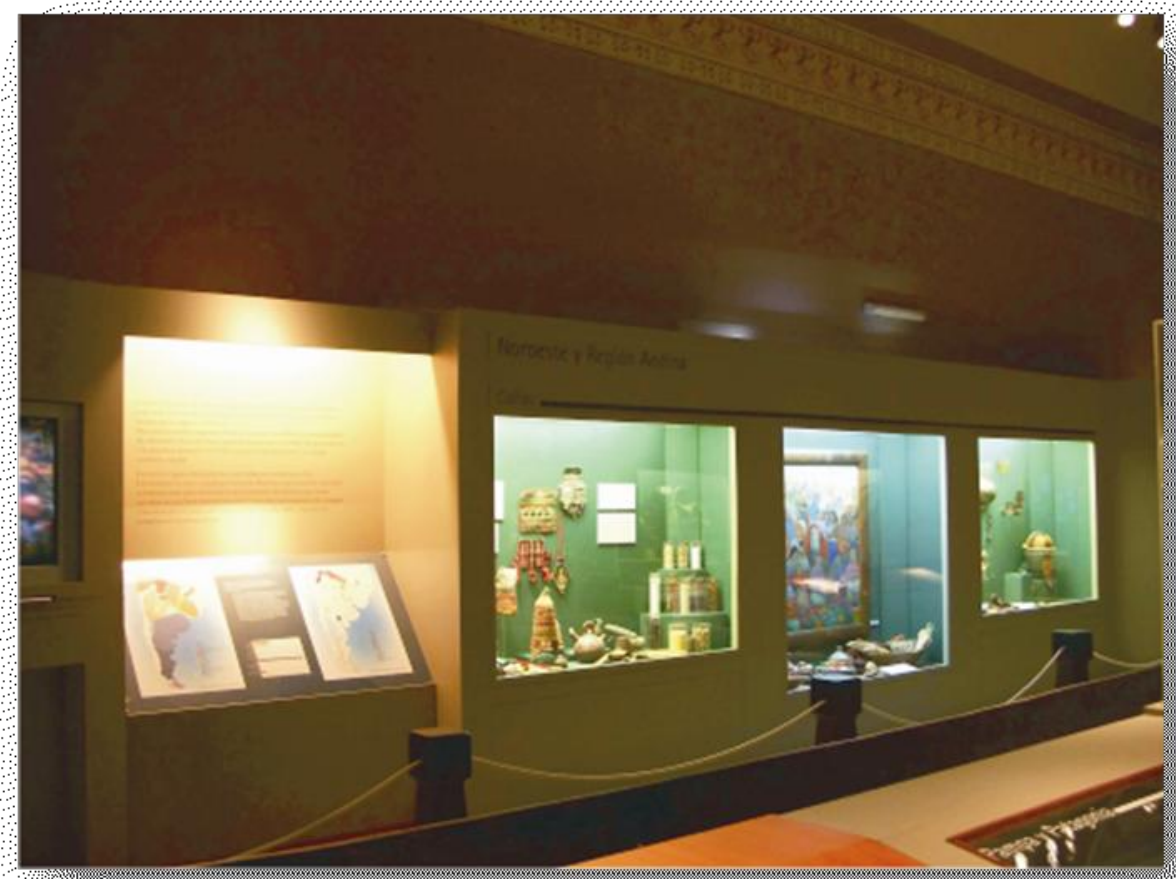

Foto $N^{o} 10$-Sector Noroeste 


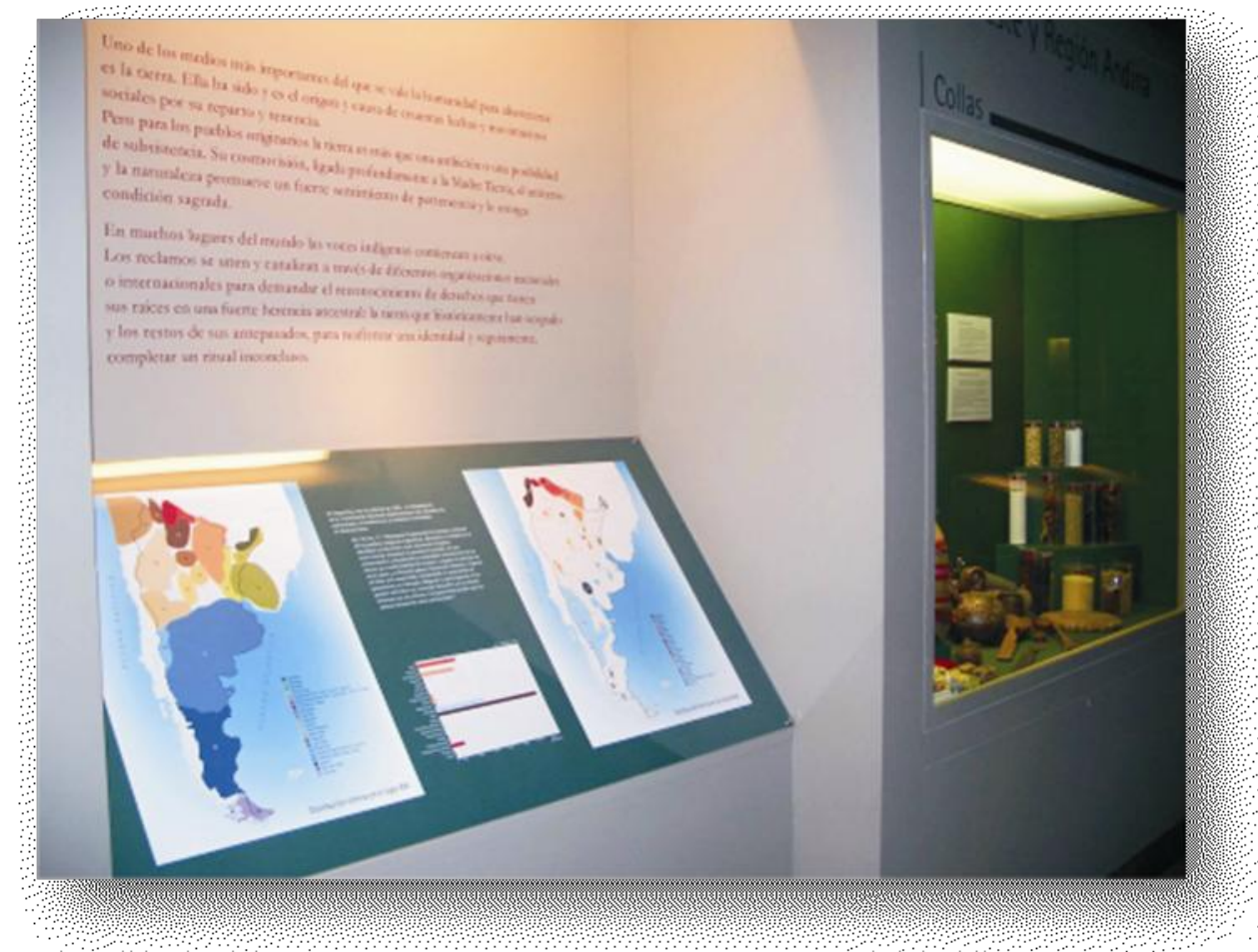

Foto $N^{o} 11$-Sector mapas

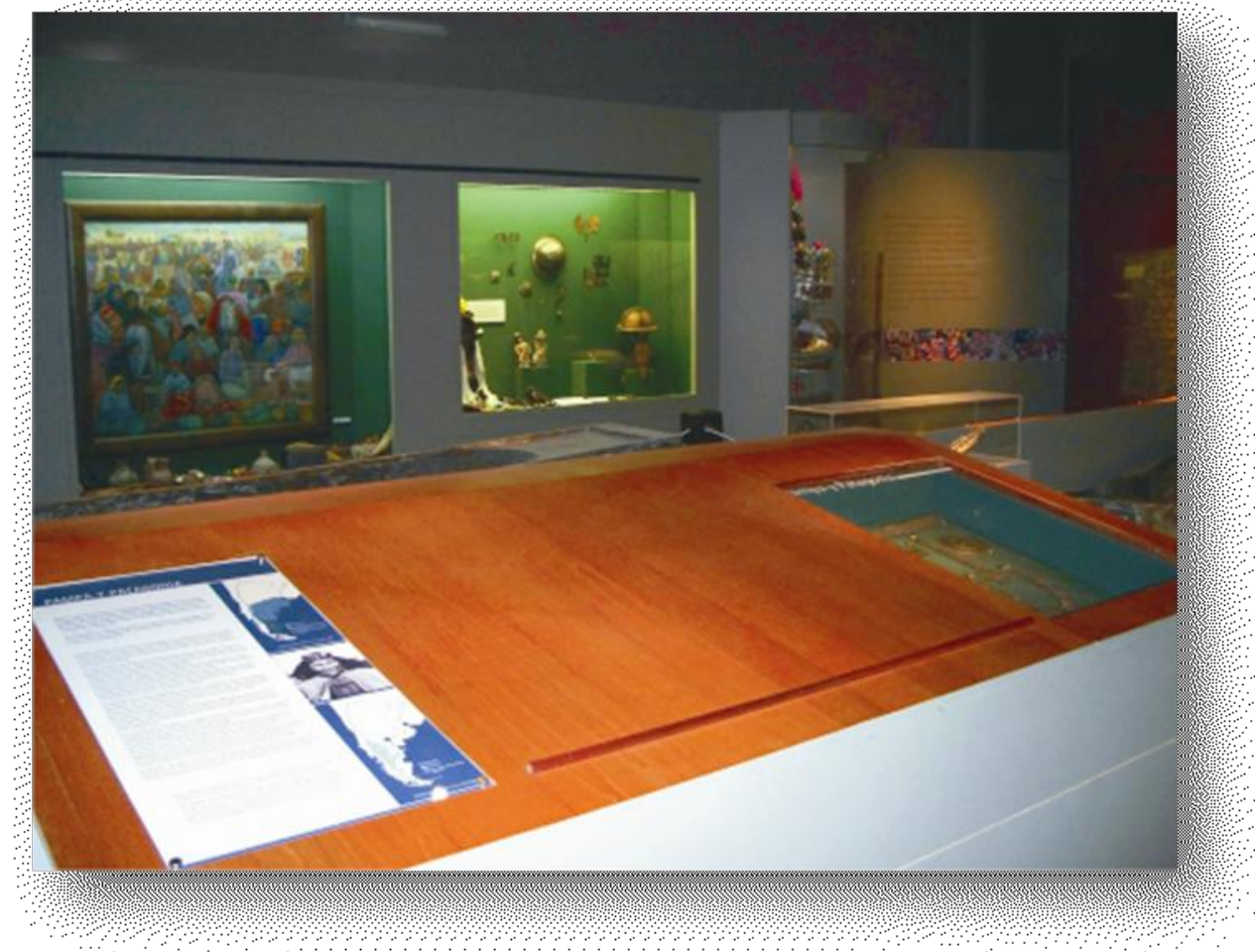

Foto $N^{o} 12$-Sector Central / pupitres 


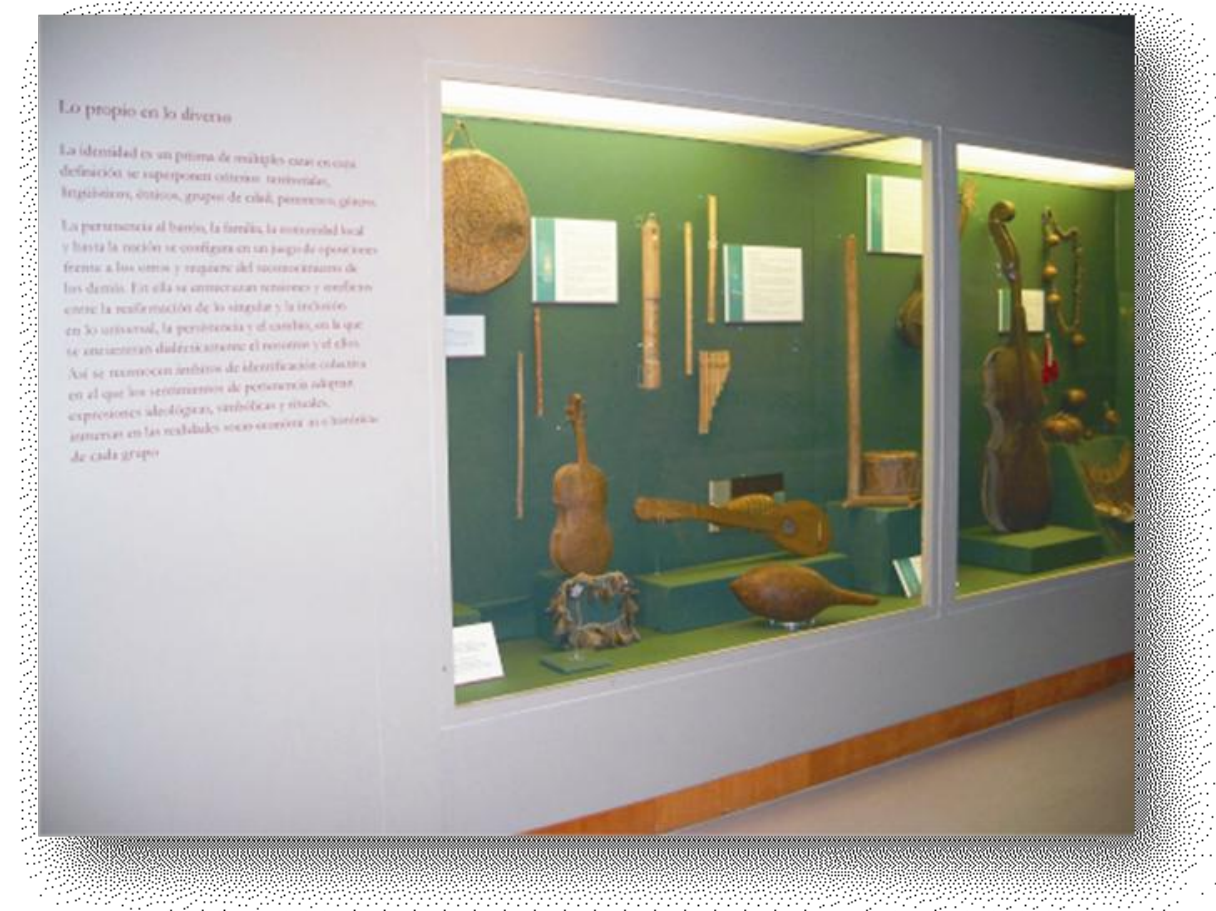

Foto $N^{o} 13$ - Sector Instrumentos musicales

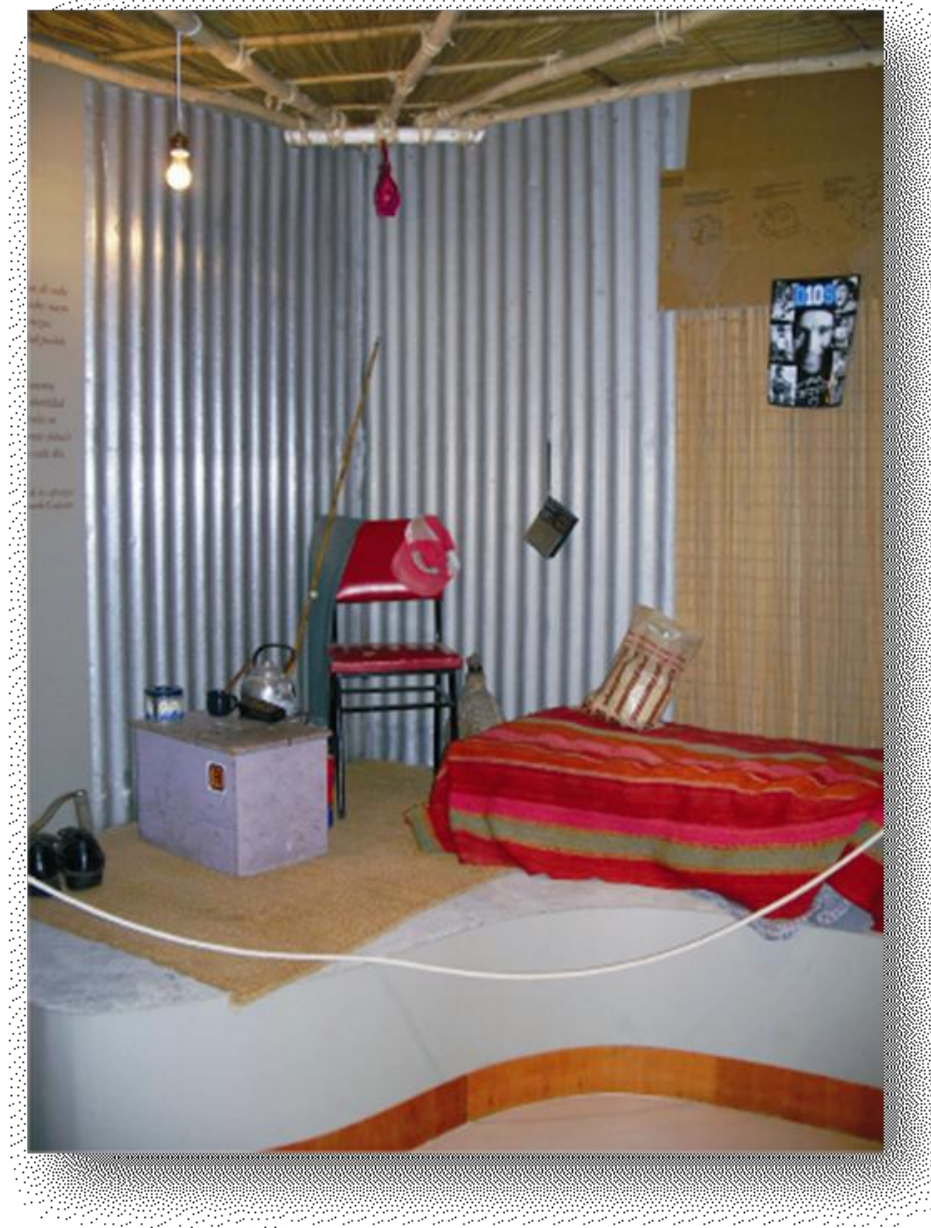

Foto $N^{o} 14$-Cierre /Sector escenario 


\section{Ejemplos de textos según jerarquización}

\section{Descriptivo diferencial:}

\section{1.a. Prácticas chamánicas}

Algunos miembros de la comunidad ostentan la condición de chamanes; individuos portadores de poderes para curar, prevenir y propiciar condiciones climáticas, evitar enfermedades y guerras. Cuando presidían una ceremonia el tocado de plumas era parte de su indumentaria.

El joven aspirante a chamán pasaba varios años de aprendiz bajo la tutela de uno de ellos hasta que, a través de un sueño un chamán fallecido, generalmente un pariente, le otorgaba su wáiuwin o poder.

\section{1.b. Manos y arcilla}

La alfarería es una tradición que se ha mantenido hasta nuestros días y está a cargo de la mujer chiriguana.

Para confeccionar las vasijas se prepara una masa con arcilla y agua. Se amasan tiras formando anillos que se superponen y unen ejerciendo presión con los dedos, luego se alisa con una piedra o caña y se deja secar al aire libre. Las piezas se decoran con pigmentos de origen mineral y vegetal, -rojo, negro o pardo-.

Las vasijas pequeñas son utilizadas con fines domésticos, mientras que las de mayor tamaño sirven para la preparación y conservación de chicha y agua.

En la actualidad, una parte de la producción se confecciona con fines comerciales.

\section{1.c. Usos de la fibra vegetal}

La cestería es una tarea que está a cargo de las mujeres. Con fibras vegetales y variadas técnicas confeccionan cestos para uso doméstico, sombreros, palmas, cedazos y estuches para plumas y flechas. También se fabrican canastos para transportar agua y redes de carga para cerámica, que son llevadas sobre la espalda y sujetadas a la cabeza por medio de un listón o tira.

\section{1.d. Técnicas de elaboración del tejido de chaguar.}

El procedimiento para elaborar la fibra incluye una serie de pasos. La mujer saca la planta con raíces, separa hoja por hoja y hace atados para facilitar el traslado. Luego pela manualmente cada hoja, las limpia, macera y raspa. Con el secado al sol obtienen un color blanquecino. La artesana, con sus dedos impregnados en ceniza, las soba sobre su mulso hasta lograr un hilado de fuerte textura. El hilo producido va enmadejado para su posterior teñido con pigmentos de origen vegetal. 


\section{Particularista e histórico}

\section{2.a. Armadura del cacique Chocorí}

Chocorí hizo famoso su nombre por su resistencia valiente de las huestes rosistas en las confrontaciones de la Expedición a los llanos.

Defensor de las pampas extremas y de los terraplenes patagónicos ante el avance blanco fue un cacique -Lonco- de grandes atributos personales y su inserción en redes de linajes prestigiosos lo vinculaban a caciques de regiones distantes.

Los enfrentamientos -incluso entre comunidades indígenas- se originaban por las disputas por las rutas del río Negro, los pasos andinos y la gestión de los recursos de las llanuras bonaerenses-

La acumulación de riqueza en la cuenca del Collón Curá y el control del camino hacia el paso del Mamuil Malal consolidadon el territorio que era conocido desde fines del siglo XVIII como el "País de las Manzanas" del cual Chocorí fue gobernador. Este territorio se extendía desde La Ventana y Bahía Blanca, pasando por Las Manzanas en Neuquén, y llegando hasta el Deseado en Santa Cruz.

En 1832, siendo Juan Manuel de Rosas gobernador de la Provincia de Buenos Aires, presentó a la Legislatura su plan contra el indio, que permitiera extender los dominios platenses hasta el Río Negro.

La campaña se inició en febrero de 1833 y Chocorí fue el principal enemigo que debió enfrentar Rosas.

A pesar que su toldería estaba usualmente sobre el río Colorado y en la isla ChoeleChoel, Chocorí viajaba constantemente por todo el territorio. Durante un tiempo fueron seguidos sus rastros hasta que finalmente fue sorprendido por el Teniente Coronel Francisco Sosa, apodado Pancho el Nato Ante la desigualdad de fuerzas, el cacique y unos pocos de los suyos huyeron, abandonando su coraza.

Pancho recogió la coraza regalándosela como valioso trofeo a su jefe supremo Juan Manuel de Rosas, quien la guardaba como valioso botín de guerra. Años más tarde, estando en poder de familiares, fue obsequiada a Francisco P. Moreno, para ser incorporada a las colecciones del museo.

Chocorí murió en 1856 por causas naturales y sobrenaturales, una explicación habitual cuando un jefe importante moría sin violencia. Junto a su nombre figuran otros tantos caciques principales como Saihueque, su hijo, Calfucurá, Chingoleo Cheuqueta, Llanquetruz, Catriel entre otros muchos. 
El traje armadura, de uso común entre los jefes y capitanes araucanos, realizada con 7 cueros de guanaco, superpuestos, curtidos y sin pelos. Las mangas se forman con 3 cueros superpuestos. El peso total es de $12 \mathrm{~kg}$.

Según el relato de varios cronistas estas armaduras eran resistentes a las puntas de flecha y se cree también a las balas de armas de fuego.

\section{2.b. Pueblos originarios}

Según la teoría más aceptada, el hombre americano habría ingresado por el estrecho de Bering desde Asia, hace 30.000 años.

Los registros arqueológicos evidencian que hace más de 12.000 años el actual territorio argentino se encontraba habitado por los primeros pobladores. Con el paso del tiempo se fueron perfilando los diversos modos de vida originarios, que pueden agruparse en grandes regiones geográfico- culturales: Tierra del Fuego, Pampa y Patagonia, Gran Chaco, Litoral Mesopotámico, Sierras Centrales, Cuyo y Noroeste Argentino.

Antes de la conquista de América, el noventa por ciento de nuestro territorio estaba ocupado por más de veinte grupos étnicos.

Con la llegada de los españoles, comienza el período de conquista y resistencia, proceso que culminó con una gran disminución de la población originaria. En consecuencia, entre los siglos XVI y XVII el panorama étnico cambió por completo.

La reorganización de los territorios ocupados se consolidó a través de la creación de ciudades, la instauración de trabajo forzado y la evangelización.

Hacia el siglo XIX las expediciones militares para la conquista de los territorios indígenas y las campañas colonizadoras llevaron este proceso hasta el genocidio. A pesar de los distintos focos de resistencia, la "Conquista del Desierto" encabezada por Julio A. Roca, provocó la desaparición de los grandes cacicazgos y con ello la desintegración de las comunidades, el confinamiento en colonias y reservas y la incorporación forzada de nuevos hábitos y formas de vida.

Herederos de una fuerte cosmovisión ligada profundamente a los fenómenos de la naturaleza, la tierra y el universo, su presencia ha persistido hasta nuestros días y hoy recuperan vigencia identidades muchas veces ocultas a la mirada occidental.

\section{2.c. Tierra del fuego}

En Tierra del Fuego convivieron cuatro grupos aborígenes: los Selknam, que ocuparon la mayor parte de Isla Grande, los Haus, habitantes de la Península Mitre, los Yámanas ubicados en ambas márgenes del Canal de Beagle hasta el Cabo de Hornos y los Alakaluf que se 
encontraban en la zona del Estrecho de Magallanes hasta el Golfo de Penas (fiordos e islas) actual territorio chileno.

El término más conocido para denominar a los Selknam y los Haus fue "Ona", que significa "gente del norte" y fueron los Yámanas quienes la utilizaron para referirse a sus vecinos. La tierra que estos grupos habitaban debe su nombre a que los primeros europeos que navegaron sus costas al ver numerosas fogatas la denominaron "Tierra del Fuego".

Se cree que los Yámanas y los Alakaluf compartían la lengua yagan mientras que los Selknam y Haus pertenecían a la familia lingüística Chon. Había entre ellos algunas diferencias dialectales y de forma de vida, pero estos límites estaban desdibujados por otra cantidad de características en común.

Los Yámanas y los Selknam constituían pequeños grupos nómades. Para los primeros, conocidos también como "nómades del mar", la canoa de corteza de haya fue un elemento alrededor del cual organizaron su modo de vida en la búsqueda de recursos marinos, base de su subsistencia. Mientras que para los Selknam, conocidos también como "nómades de la tierra", el guanaco era un animal de importancia vital siendo el arco y la flecha la principal arma de caza, actividad realizada por los hombres. Las mujeres tenían a su cargo la recolección de bayas, semillas, hongos, huevos de aves, mariscos.

Entre los Yámanas los hombres se dedicaban a las actividades de caza de animales marinos como lobos, nutrias, ballenas para la cual utilizaban arpones; mientras las mujeres realizaban recolección de mariscos y al igual que las Selknam, tejían canastas, cosían pieles y cueros y contribuían a la construcción de las viviendas, el cuidado del fuego, la preparación de alimentos y el abastecimiento de agua dulce.

Ambos grupos protegían su cuerpo con grasa de lobo marino para soportar las bajas temperaturas, cubriéndose con pieles para protegerse del viento. Su vestimenta consistía en el uso de cueros de lobo marino para los yámanas y cuero de guanaco para los selknam. Las mujeres completaban su vestimenta con collares de huesos o caracoles y pulseras de cuero.

En lo que respecta a la organización social, en ambos grupos la familia, constituía una institución social independiente, sin embargo, ninguna de ellas permanecía aislada. Prescindían de jefes, consejo de ancianos u otro órgano de autoridad y aún los hombres que gozaban de más prestigio, como los shamanes, contribuían a la economía del grupo de manera análoga a los demás. Estos últimos eran los intermediarios entre el mundo sobrenatural y los hombres, tomaban parte en todos los rituales y ceremonias y tenían la facultad de curar.

Ambos grupos realizaban ceremonias de iniciación para marcar el paso a la adultez. Esta tenía características particulares dependiendo de si los iniciados eran mujeres o varones. 
Entre los ya manas, el Ciegas incluía ambos sexos; no obstante realizaban una ceremonia secreta entre los hombres denominada Kina que entre los Selknam recibía el nombre de Han.

\section{$\underline{\text { Situación Actual }}$}

Luego del contacto con los europeos, ya sea por la propagación de enfermedades o la reducción de su territorio por la creciente actividad lanera, estos grupos se redujeron considerablemente.

De los Yamena, quedan hoy unas pocas personas que se auto reconocen como tales, radicadas en Puerto Williams (isla Navarijo Chile). En 1995, la población Yamena alcanzaba un total aproximado de 74 personas.

Las personas que se auto reconocen como Selknam viven en Río Grande y conforman la comunidad Rafaela Aston. En enero de 1999, el gobierno fueguino les reconoció las tierras que históricamente han reclamado: 36.000 hectáreas en Tolueno, Tierra del Fuego.

Varios integrantes de estas comunidades desarrollan vida rural, en general como empleados en establecimientos agro ganaderos. El resto de la población laboral activa vive de trabajos ocasionales, especialmente en la construcción, servicios de hogar, y venta de artesanías al turismo.

\section{Sistemático-cultural}

\section{3.a. Máscaras y enmascaramiento}

Las máscaras constituyen una de las producciones escultóricas más difundidas entre los pueblos. Además de una expresión artística, son portadoras de significados y poseen un fuerte poder para invocar y provocar la asistencia de los antepasados.

En muchas culturas, el enmascaramiento es una forma de conexión entre la vida y la muerte, lo natural y lo sobrenatural, la ficción y la realidad. Al cubrirse parcial o totalmente el rostro, el enmascarado adquiere variadas identidades y desempeña roles transitorios que complementa con trajes, movimientos del cuerpo, cantos y danzas.

Las hay antropomorfas, zoomorfas, confeccionadas en estilo realista hasta el más figurativo. Presentes en el teatro, la guerra, enterratorios, carnaval y los ritos de pasaje e iniciación, en la riqueza de materiales y su combinación se devela el temor, la muerte y la risa.

\section{3.b. Fiestas de encuentro (región andina)}

Danzas, cantos y música son los medios de expresión predilectos del hombre andino. Este lenguaje particular sirve para celebrar y para llorar, sembrar y conjurar los fenómenos de la naturaleza, amar y honrar a los muertos- 
A pesar de las grandes distancias entre un valle y otro, encuentros rituales, ferias y fiestas fortalecen los lazos sociales, estableciendo canales de intercambio multiétnico donde la gran diversidad de pueblos de la región se une bajo el abrazo de la Madre Tierra o Pachamama, dadora de vida.

\section{3.c. Hijos de la Tierra}

Uno de los medios más importantes del que se vale la humanidad para abastecerse es la tierra. Ella ha sido y es el origen y causa de cruentas luchas y movimientos sociales por su reparto y tenencia. Pero para los pueblos originarios la tierra es más que una ambición o una posibilidad de subsistencia. Su cosmovisión ligada profundamente a la Madre Tierra, el universo y la naturaleza promueve un fuerte sentimiento de pertenencia y le otorga condición sagrada.

En muchos lugares del mundo las voces indígenas comienzan a oírse. Los reclamos se unen y canalizan a través de diferentes organizaciones nacionales e internacionales para demandar el reconocimiento de derechos que tienen sus raíces en una fuerte herencias ancestral: la tierra que históricamente han ocupado y los restos de sus antepasados, para reafirmar una identidad y seguramente completar un ritual inconcluso.

\section{Teórico disciplinar}

\section{4.a. Panel de ingreso}

Este maniquí presenta las características propias de las formas de exhibición de fines del siglo XIX y principios del XX. Representaciones de carácter realista en cuyos rasgos se ponen en evidencia la mirada occidental sobre las diferencias culturales.

Permanece en esta sala custodiando la memoria de los pueblos originarios de la Argentina que, como espejos culturales, nos invitan a vernos con y desde los otros.

Desde el pasado de las colecciones exhibidas nos aproximamos al presente de los pueblos originarios para reflexionar sobre el futuro, valorar la diversidad cultural y reconocernos inmersos en un mundo pluricultural.

\section{4.b. (Panel de cierre)}

Ninguna cultura se extingue de pronto y del todo, su presencia transita nuevas formas y se adhiere y se contagia y persiste. La destrucción física e histórica de una cultura, una identidad o una idea, tiene al olvido como su peor amenaza.

Aunque el mundo parece homogeneizarse, con solo mirar a nuestro alrededor, habrá siempre lugar para una reflexión sobre la diversidad. 


\section{4.c. Lo propio en lo diverso}

La identidad es un prisma de múltiples caras en cuya definición se superponen criterios territoriales, lingüísticos, étnicos, grupos de edad, parentesco, género.

La pertenencia al barrio, la familia, la comunidad local y hasta la nación se configura en un juego de oposiciones frente a los otros y requiere del reconocimiento de los demás. En ella se entrecruzan tensiones y conflictos entre la reafirmación de lo singular y la inclusión en lo universal, la persistencia y el cambio, en la que se encuentran dialécticamente el nosotros y el ellos.

Así se reconocen ámbitos de identificación colectiva en el que los sentimientos de pertenencia adoptan expresiones ideológicas, simbólicas y rituales, inmersas en las realidades socio-económicas e históricas de cada grupo. 


\title{
Capítulo V \\ LOS VISITANTES Y EL CONTEXTO DE APROPIACIÓN
}

\author{
"Vivir en este mundo múltiple significa experimentar \\ la libertad como oscilación continua entre la \\ pertenencia y el extrañamiento." (G. Vattimo, 1996).
}




\section{Capítulo V: LOS VISITANTES Y EL CONTEXTO DE APROPIACIÓN}

\section{V.1. Antecedentes en el estudio de visitantes a museos}

Los antecedentes más antiguos sobre estudio de público se remontan al momento de la formación de los grandes museos europeos, particularmente a la apertura del museo del Louvre (1798). Acompañando la nueva mirada de estas instituciones que ya no cumplen la función de almacenamiento de curiosidades sino la de difundir y explicar una nueva forma de ver el mundo, vinculada a la revolución científica de fines del siglo XVIII y la transformación social y política producida a partir de la Revolución Francesa, que determina la emergencia de las clases medias en el siglo XIX y la aparición del ocio y las necesidades de formación y educación. El público se amplía de la élite cultural a un público heterogéneo, con distintos niveles de instrucción y diversos intereses.

Pero es en la primera mitad del siglo XX donde comienzan estudios más sistemáticos, con diversas perspectivas y sustentados en el aporte de disciplinas científicas.

Los primeros estudios de público se llevaran a cabo con motivo de las grandes exposiciones universales de finales del siglo XIX. Entre los años 1950 a 1970, la posguerra marca el punto más bajo en lo que a la investigación sistemática de estudios de público se refiere y hacia los años sesenta se reactivan, coincidiendo con el aporte de las ciencias sociales. Dos grandes instituciones serán centros activos en esta área: el Milwaukee Public Museum y la Smithsonian Institution. Durante los años 60 la evaluación comienza a centrarse en los aspectos educativos, con énfasis en las motivaciones de la visita.

En Europa se destacan los trabajos de Bourdieu y Darbel de 1962. Con una mirada sociológica, se pone el énfasis en el tipo de público que asiste a los museos, de lo que resulta una variable significativa para la asistencia el alto nivel de instrucción.

A fines de la década del 60 los trabajos de Harris Shettel y Chanter Screven marcan un momento crucial. Con ellos los estudios de visitantes a museos comienza a convertirse en un campo de conocimiento cuya fuente es el medio educacional. Interesados esencialmente por la transmisión del mensaje expositivo, sus principales aportaciones son de índole teórica y metodológica. Aplican los procedimientos de 
investigación educativa a la evaluación de exposiciones y proponen un enfoque de la evaluación centrado en objetivos de aprendizaje. Comienzan los trabajos desde el punto de vista cognitivo. ${ }^{51}$ (Pérez Santos, 2000). Dentro de esta línea se destacan los trabajos de Mikel Asensio (1985).

El desarrollo de nuevas estrategias expositivas y la incorporación de elementos dinámicos ha sido una de las alternativas de la innovación de los museos en los últimos años. Sin embargo, el cambio más profundo reside en el desplazamiento del centro de atención desde el objeto hacia el visitante, para analizar, desde distintos puntos de vista, las manera en que éstos se conectan con la exhibición, tanto en sus aspectos cognitivos, comportamentales y emocionales.

Las propuestas hacia los visitantes se han vuelto más pretenciosas respecto del tipo e intensidad de la experiencia que pretende promover en la visita.

Estamos ante un cambio de paradigma museológico: del museo que exhibe colecciones al museo que comunica, de una idea de público general indiferenciado a otro público con competencia e intereses diversos, de la función de conservación a la de comunicación e interacción entre el mundo del visitante y la propuesta del museo. En el capítulo dos se explicitaron los elementos fundamentales que caracterizan a los nuevos modelos expositivos. Más allá de la sistematización de las variables del cambio, la posibilidad de generar una experiencia dinámica de retroalimentación entre la exhibición y el público reside en la preocupación aún más profunda que implica la accesibilidad de públicos diversos. Para esto, desplazar la preocupación hacia el visitante implica conocer todas sus potencialidades como sujeto activo, cognoscente e histórico.

Las funciones de los museos exceden su rol como gestores y custodios del patrimonio cultural y sus usos e interpretaciones tiene que ver con una transformación que implica un cambio de los axiomas que dan legitimidad a la producción del conocimiento. El patrimonio cultural es concebido como un repertorio de connotaciones,

\footnotetext{
51 “A finales de los ochenta se pusieron en marcha varios programas de evaluación, basados en los estudios ingleses y norteamericanos, como el programa REMUS (1990). De estos programas surgió la creación en 1990 en los museos franceses, del Observatoire Permanent des Publics. (OPP) Con metodología de encuesta, el OPP investiga las variables más relevantes relacionadas con el público visitante antecedentes, y características de la visita (motivos, compañía, etc.) valoración de la misma (satisfacción general y sobre distintos aspectos), utilización de servicios, disposición a volver. En 1991 se crea en Estados Unidos la asociación profesional de Visitor Studies Association” (Pérez Santos, 2000:34).
} 
de signos, que cobran existencia en un espacio dinámico de construcción de mensajes donde se ejercen los derechos y elecciones según cada sociedad y época particular.

Esta apertura hacia el abanico de interpretaciones posibles elimina la lectura por parte del visitante de un relato unívoco. Las nuevas estrategias comunicativas promueven una actitud participativa en términos intelectuales, emocionales y lúdicos. A su vez, cada visitante se conecta de modo diferencial con la exhibición, su percepción es selectiva, de modo que en él recae mucho más la producción de nuevas síntesis cognoscitivas que la adquisición de información acabada. Para esto es necesario dar mayor espacio al protagonismo, la interacción y el espíritu crítico. La conceptualización del proceso educativo experimenta un cambio, "de la memorización a la comprensión, de la incorporación de la información a la discriminación de mensajes, de la adquisición enciclopédica a la adquisición selectiva, del aprender al aprender a aprender." (Hopenhayn, 2002:299).

El conjunto de relaciones adjudicadas desde el conocimiento científico a un objeto de colección no son necesariamente concordantes con el conjunto de significaciones que le da el visitante, proyectando, en la mayoría de los casos, sus categorías cognitivas y poniendo en juego distinciones, atributos y relaciones propias.

Establecer un puente entre ambas miradas es la función de la exhibición y allí se instala la instancia evaluativa del proceso de aprendizaje por parte del visitante.

Entre los llamados estudios de público de museo se pueden reconocer distintas líneas de trabajo e intereses. Por un lado se han desarrollado investigaciones descriptivas sobre las conductas que desarrolla el visitante tanto en la propuesta global del museo como de una exposición en particular. El tiempo que dura la visita, los lugares donde se detiene el visitante, el recorrido elegido, la intercomunicación con otros visitantes, el uso del espacio, son algunas de las variables consideradas desde este interés y desde la observación directa. Encuestas estructuradas o semiestructuradas son de uso frecuente en este tipo de instituciones con la intención de adecuar la propuesta a las necesidades y preferencias del público. A partir de un conjunto de categorías preestablecidas estas encuestas arrojan en forma estadística los datos sociodemográficos, permiten definir el tipo y perfil del público asistente, así como la frecuencia de la visita, los circuitos de información, etc. Apuntan al mejoramiento de las estrategias de atracción de público. Además, en algunos casos, se incluye la 
determinación de las expectativas y los niveles de satisfacción logrados, de manera de redefinir o reformular la propuesta expositiva o una parte de ella. Estas aproximaciones son compatibles entre sí, se utilizan simultáneamente y en forma complementaria. Muchas veces se emplean según las etapas y el momento del desarrollo del programa museístico. Pueden ser previas a su realización, durante el proceso de producción o una vez culminada la exposición, y constituyen en todos los casos una herramienta para la toma de decisiones.

No es menor el impacto de la teoría de la comunicación y los estudios de recepción como marco de análisis para las investigaciones sobre público. El pasaje de una teoría de la comunicación preocupada por los sistemas de transferencia en un circuito lineal dado por la relación emisor-receptor, en el que los problemas de interpretación quedaban reducidos a la categoría de ruido hacia su comprensión como proceso circular, multifacético y, en palabras de Bateson (....) orquestal, provocó un cambio profundo en la comprensión de la situación comunicativa generada en una sala de exhibición. Entre los trabajos que adoptan una perspectiva comunicacional e integradora se encuentran los desarrollados por Marilia Cury $(1999,2005)$.

En Latinoamérica, los trabajos de N. García Canclini se centran en el consumo cultural, en el marco del impacto de los medios de comunicación masiva, la dinámica global y la construcción de identidad, poniendo en valor la diversidad y el multiculturalismo. A partir del analisis de la apropiación por parte del público de cuatro exposiciones de arte, concluiye que los museos reproducen las desigualdades sociales. ${ }^{52}$

Más recientemente, los estudios de visitante se han orientado hacia la comprensión de la experiencia de aprendizaje vivida durante la visita. Desde un punto de vista cognitivo y nutriéndose de las propuestas teórico metodológicas de distintas disciplinas como la psicología, la sociología, las ciencias de la educación, entre otras, se busca conocer el conjunto de procedimientos por los cuales se ponen en juego categorías de pensamiento para arribar a la construcción de sentido. Los conjuntos relacionales y asociaciones que se disparan al interior de la sala de exhibición, ancladas

\footnotetext{
${ }^{52}$ Ver "Consumidores y ciudadanos" (1996) y "La investigación sobre público: base de la educación en museos". (1985)
} 
en los diversos objetos y recursos expositivos y desde el conjunto de ideas, nociones, conceptos y experiencias que cada visitante trae consigo, según sus hábitos cognitivos. ${ }^{53}$

Así los estudios de visitantes a museos, operan sobre la dimensión simbólica y cognitiva del patrimonio cultural y tienden a ocupar un rol fundamental en el campo de la gestión cultural y el análisis crítico. Los estudios de las diferentes modalidades de percepción/ interpretación tanto en las instancias de la recepción del público como de la producción por los expertos no son una área solo de interés académico, son una área crucial en la gestión del patrimonio cultural y la planificación de las nuevas funciones de los museos en el mundo contemporáneo (Cousillas, 1997).

Este interés creciente por conocer al destinatario de las exhibiciones está asociado, entre otras razones, con transformaciones que ha experimentado el concepto de patrimonio cultural y las propuestas expositivas de los museos que buscan generar un espacio de aprendizaje significativo. La evaluación y análisis de las formas en que los visitantes perciben, recepcionan y elaboran los mensajes propuestos, constituye una instancia fundamental tanto para la reformulación de las propuestas como para el desarrollo de una política institucional que aspire a cumplir su misión educativa.

\section{V.2. Cognición, habitus y capital cultural}

Una de las disciplinas de mayor influencia dentro de esta línea de investigación ha sido la psicología cuyos cambios paradigmáticos han influido fuertemente en la evaluación de público. “Así, los primeros estudios de evaluación de exposiciones se fundamentan en las teorías conductistas imperantes en la época (Melton, 1935; Robinson, 1928), siendo el enfoque conductual el modelo teórico básico de la mayor parte de las investigaciones que conforman el cuerpo de conocimientos de esta área.

A partir de los años setenta los estudios sobre el aprendizaje en los museos se vieron influenciados por la psicología cognitiva experimental y las teorías de la educación formal (Gibson, 1969, Ausubel, Novak y Hanesian, 1978), llevándose a cabo gran cantidad de investigaciones basadas en los modelos constructivistas de adquisición del conocimiento. (Borun, 1977, 1990, 1991; Koran, Longino y Shafer, 1983, Koran y

\footnotetext{
${ }^{53}$ Para profundizar en la diversidad de enfoques y antecedentes de estudios de visitantes se sugiere consultar el trabajo de Tesis Doctoral de Sandra Murriello (2006) y el trabajo de Eloísa Pérez Santos (2000).
} 
Ellis, 1991) que consideran que la cognición y el aprendizaje son el resultado de la coordinación y la resolución de conflictos cognitivos entre los individuos.

"Desde la perspectiva constructivista del conocimiento, las personas procesan nuevos conocimientos sobre las estructuras cognoscitivas ya existentes que dan sentido a los mismos. De esta forma los visitantes que acuden a una exposición no vienen con sus mentes en blanco, sino con esquemas cognitivos previos en los cuales se pueda acoplar/conectar/asociar la nueva información. Conocer, por tanto, cuáles son esos esquemas cognitivos que el visitante posee sobre un tema dado puede llegar a ser fundamental para elaborar los contenidos expositivos. Por otra parte, los conocimientos previos del visitante condicionan de manera decisiva la adquisición de conocimientos nuevos, al funcionar los primeros como modelos que ayudan a interpretar los segundos (Pozo, 1996). Por ello, en ocasiones puede resultar más interesante desarrollar exposiciones que traten de cambiar estructuras previas comúnmente erróneas en los visitantes que montajes a un nivel conceptual muy elevado que traten de aportar nuevos conocimientos difícilmente asimilables sin una adecuada estructura cognoscitiva previa capaz de integrar la nueva información. (...) Sobre la base de que el conocimiento humano responde a un principio constructivista, la evaluación del aprendizaje, entendido como modificación de estructuras cognitivas existentes, se centra en el visitante y en la forma en que procesa los contenidos expositivos." (Pérez Santos, 2000:193). ${ }^{54}$

Asimismo, una inadecuada asociación de lo cognitivo con lo verbal y lo racional, ha relegado a lo afectivo a un segundo plano. Sin embargo, el papel desempeñado por las actitudes o las emociones en el aprendizaje no deja lugar a dudas respecto a la importancia de los aspectos afectivos en el procesamiento y adquisición de la información.

Cada visitante trae consigo un universo cultural, expectativas, necesidades, experiencias, prácticas y representaciones que se "activan" en el espacio comunicativo

\footnotetext{
54 El aprendizaje no formal requiere de un acercamiento radicalmente distinto al del aprendizaje formal por ejemplo de la escuela: ocurre voluntariamente (nadie te obliga a aprender en un museo), no se establece secuencia ni currícula, puede ocurrir en una gran variedad de contextos (jardines zoológicos, museos, centros de ciencia, etc.), es ubicuo (porque ocurre en muchos lugares, a cualquier hora del día y en cualquier momento de la vida) (Pérez Santos, 2000).
} 
propuesto por la exhibición. A su vez, percibe, distingue, selecciona e interpreta los diversos contextos temáticos materializados en los distintos recursos expositivos.

Existe mayor afinidad entre aquellas imágenes que veo y otras imágenes con las que estoy familiarizado, que percibí históricamente. Cuando aquello que percibo ingresa en esta estructura de sentido decimos que se conoce algo. Conocer es aprehender un dato de una cierta función, bajo cierta relación, en tanto significa algo, dentro de una determinada estructura (Miguelez, 1995).

Cada visitante realiza una síntesis cognitiva frente a la propuesta del museo, selecciona una de las múltiples estrategias posibles de recorrido, evoca de lo ya visto, de lo ya escuchado, una secuencia de signos de acuerdo a "una disposición de su mente" y a partir de ello, se identifica, considera ajeno, se sorprende, ignora o rechaza aquello que ha seleccionado como campo de significación del despliegue expositivo. Por otro lado, la visita al museo está atravesada por la experiencia estética y emocional que alimenta la apertura hacia las interpretaciones.

Así, el museo propone al visitante una triple actividad:

- Pragmática, aquella identificable en la visita con su desplazamiento y estructurada en una serie de acciones físicas más o menos reguladas.

- Cognitiva, la acción de adquirir un determinado saber garantizado por el museo y en el que se manifiestan los valores profundos de una cultura. En este sentido puede hablarse del museo como espacio cognitivo en el que tiene lugar la búsqueda del sujeto que procura la conjunción con el objeto de valor.

- Estética, en la medida en que el visitante puede llegar a una esthesis en su relación con la propuesta museográfica. (Zunzunegui, 2003).

A su vez, la visita a un museo involucra tres contextos: personal, social y físico. El contexto personal incluye los intereses, motivaciones e inquietudes de los visitantes, que pueden influir de una manera decisiva en los resultados de la visita. El contexto social implica a las personas con las que realiza la visita, los contactos con otros visitantes y con el personal del propio museo, que juegan un papel relevante en la experiencia museística. El contexto físico engloba tanto los aspectos arquitectónicos, como los objetos y artefactos que contiene el museo y que ejercen una poderosa influencia durante la visita. (Pérez Santos, 2000). 
La interacción entre estos ámbitos resulta en una construcción única por parte del visitante, creando la experiencia de la visita. De esta forma, la atención prestada, por ejemplo, a una exposición está filtrada por el contexto personal, mediatizada por el contexto social e inmersa en el contexto físico. Aunque cada uno de estos contextos puede considerarse de forma separada, funcionan en la realidad como un todo integrado.

Ahora bien, las formas de apropiación cognitiva del patrimonio exhibido se instala en el espacio de una experiencia situada, condicionada por las restricciones materializadas en el contexto de representación y actualizada por cada interpretante según un sistema de relaciones que involucra su capital cultural y se "hace visible" a través de su producción discursiva. El habitus, producto y lugar de la historia individual y colectiva asegura la presencia activa de las experiencias pasadas que, depositadas en cada organismo bajo la forma de esquemas de percepción, de pensamiento y de acción, tiende, más seguramente que todas las reglas formales y todas las normas explícitas, a garantizar la conformidad de las tácticas y su constancia a través del tiempo. (Bourdieu, 1996).

La noción de habitus definida por Bourideu permite asumir las estructuras cognitivas de los individuos como estructuras sociales incorporadas. El habitus es una capacidad adquirida y naturalizada que contiene la historia individual y los contextos de las prácticas sociales. Así, la génesis del discurso está enraizada en el capital cultural. Este es el conjunto de saberes y disposiciones adquiridas socialmente que permiten producir y reproducir las estrategias de acción y apropiación. El capital cultural no puede ser acumulado más allá de las capacidades de apropiación de un agente singular y muere con las capacidades biológicas de su portador. ${ }^{55}$

Desde el punto de vista epistemológico, y asumiendo sus connotaciones para nuestro campo de análisis, el concepto de habitus (y su marco relacional con el concepto de capital cultural) permite, desde Bourdieu, instalar la investigación en un punto de encuentro entre las posturas objetivistas y subjetivistas. La génesis del significado tiene carácter relacional. ${ }^{56}$

\footnotetext{
${ }^{55}$ En relación a los museos Bourdieu analizó la apropiación del arte como elemento distintivo de clase.

56 "De modo muy general, la ciencia social, en antropología como en sociología o en historia, oscila entre dos puntos de vista aparentemente incompatibles: el objetivismo y el subjetivismo, o, si se prefiere, el fisicalismo y el psicologismo (que puede tomar distintos matices, fenomenológico, semiológico, etcétera). Por un lado puede "tratar los hechos sociales como cosas", según la vieja máxima durkheimiana, y dejar así de lado todo lo que deben al hecho de que son objetos de conocimiento -o de desconocimiento- en la existencia social. Por otro lado, puede reducir el mundo social a las representaciones que de él se hacen
} 
... "las representaciones de los agentes varían según su posición (y los intereses asociados) y según su habitus (...) El habitus es a la vez un sistema de esquemas de producción de prácticas, un sistema de esquemas de percepción y de apreciación de las prácticas. Y, en los dos casos, sus operaciones expresan la posición social en la cual se ha construido. En consecuencia, el habitus produce prácticas y representaciones que están disponibles para la clasificación, que están objetivamente diferenciadas; pero no son inmediatamente percibidas como tales más que por los agentes que poseen el código, los esquemas clasificatorios necesarios para comprender su sentido social." (Boudieru, 1996:134).

"Los objetos del mundo social, (...) pueden ser percibidos y expresados de diversas maneras, porque siempre comportan una parte de indeterminación y de imprecisión y, al mismo tiempo un cierto grado de elasticidad semántica: en efecto, aun las combinaciones de propiedades más constantes están siempre fundadas sobre conexiones estadísticas entre rasgos intercambiables; y, además, están sometidas a variaciones en el tiempo de suerte que su sentido, en la medida en que depende del futuro está también a la espera y relativamente indeterminado. Este elemento objetivo de incertidumbre -que es a menudo reforzado por el efecto de categorización, pudiendo la misma palabra cubrir prácticas diferentes- provee una base a la pluralidad de visiones del mundo, ella misma ligada a la pluralidad de puntos de vista y, al mismo tiempo, una base para las luchas simbólicas por el poder de producir y de imponer la visión del mundo legítima." (Bourdieu, 1996:136).

Estas consideraciones nos llevan directamente a la reflexión acerca de la complejidad de nuestro ámbito de análisis. Los recortes analíticos justificados bajo el marco de la experiencia comunicativa en el museo asumen las restricciones de una referencialidad situada; pero esto no nos debe llevar al engaño de un reduccionismo simplificador. Las nociones teóricas de la teoría de los campos de Pierre Bourdieu nos permiten pensar que el sujeto cognoscente es un sujeto social e histórico a la vez que la institución museo es un campo de confluencia de poderes, intereses, tensiones generadas por el lugar que cada agente social ocupa en el campo disciplinar.

En tal sentido, el proceso de aprendizaje que se promueve en la sala de exhibición no es de carácter instructivo, apuntando a acrecentar la información del producidos por los sujetos sociales.”(Boudieu, 1996:128). 
visitante. "Un resultado común en las evaluaciones de exposiciones empieza a ser la comprobación de que el aprendizaje de los visitantes no es tan importante como cabría suponer desde una perspectiva puramente educativa (...) siguiendo a Uzzell existen varias posibles explicaciones para justificar este hecho: primero, la gente no aprende cuando queremos que lo hagan o aprenden otras cosas que no evaluamos. Segundo, muestras técnicas de evaluación no son lo suficientemente sensitivas para evaluar el cambio que ocurre en el sujeto como resultado de la asistencia a una exposición. Tercero, utilizamos diferentes definiciones de aprendizaje, por lo que el proceso de aprender en mayor o menor medida depende de cómo y qué entendemos por aprendizaje. (...) Es posible que algunas de estas suposiciones sean ciertas... el cambio cognitivo producido como consecuencia de la visita no puede reducirse a la adquisición de conceptos o al recuerdo de un tipo determinado de información. Por el contrario, en la experiencia global de la visita intervienen procesos complejos e interrelacionados que hacen que la adquisición de conocimientos interactúe con aspectos emocionales, perceptivos, motivacionales, actitudinales, motrices, etc. En la medida que seamos capaces de desentrañar estas relaciones, la evaluación del aprendizaje estará más o menos al alcance. (Pérez Santos, 2000:121).

Según Ausubel (1983) un aprendizaje es significativo cuando los contenidos son relacionados de modo no arbitrario y sustancial en lo que al alumno (visitante) ya sabe. Por relación no arbitraria y sustancial se debe entender que las ideas se relacionan con algún aspecto existente específicamente relevante de la estructura cognoscitiva del individuo como una imagen, un símbolo o un concepto. ${ }^{57}$ Una de las estrategias de aprendizaje que apuntan a la realización de asociaciones significativas es aquella que se dirige, por analogía, comparación, contraste u oposición al conocimiento que el individuo tiene como resultado de la percepción/recepción/comprensión de su mundo

\footnotetext{
57 Ausubel distingue el aprendizaje significativo del aprendizaje por repetición. Ambos han sido erróneamente equiparados al aprendizaje por descubrimiento y al aprendizaje por recepción respectivamente. Sus consideraciones toman como referencia la circunstancia particular de la enseñanza en el aula y son trasladables, sin perder de vista la particular experiencia del visitante, al aprendizaje en el museo. En tal sentido, para Ausubel hay aprendizaje significativo... "si la tarea de aprendizaje puede relacionarse, de modo no arbitrario y sustancial (no al pie de la letra), con lo que el alumno ya sabe y si este adopta la actitud de aprendizaje correspondiente para hacerlo así. El aprendizaje por repetición, por otra parte, se da cuando la tarea de aprendizaje consta de puras asociaciones arbitrarias, como la de pares asociados, la caja de trucos, el laberinto o el aprendizaje de series; si el alumno carece de conocimientos previos relevantes y necesarios para hacer que la tarea de aprendizaje sea potencialmente significativa, y también (independientemente de la cantidad de significado potencial que la tarea tenga) si el alumno adopta la actitud simple de internalizarla de modo arbitrario y al pie de la letra (es decir, como una serie arbitraria de palabras." (Ausubel, 1983:37).
} 
cotidiano. En la experiencia de la visita al museo, no se trata necesariamente de asociaciones "correctas" en el sentido instructivo del término, sino de experimentar situaciones reflexivas que minimicen la distancia entre la propuesta expositiva y el mundo del visitante. De allí que la exposición generalmente está tan cargada de azar e incertidumbre como de certezas y confirmaciones. De allí que se constituya en un espacio abierto, dinámico, que admite variadas lecturas.

En la misma línea de pensamiento se encuentran los trabajos de M. Asensio para quien "desde la perspectiva psicológica más moderna, el aprendizaje se considera un proceso situado, contextual y pragmático, ligado a dominios y ámbitos específicos de conocimiento, con un enlace y aplicabilidad directos a situaciones cotidianas, con un papel activo del aprendiz, tanto en el plano mental como conductual y actitudinal. La investigación que ha empezando a comparar los aprendizajes formales, aquellos que se dan en el aula, y los aprendizajes informales, aquellos que se dan en contextos naturales, está empezando a mostrar que el aprendizaje informal no sólo es posible sino que es una herramienta muy potente para salvar algunas de las limitaciones más importantes del aprendizaje formal. En este nuevo escenario, los museos y exposiciones son un ámbito privilegiado para promover un acceso al conocimiento que, conservando el rigor necesario del mensaje científico, aporte una nueva mirada a los procesos del aprendizaje clásico.” (Asensio, 1983).

En esta tesis, el análisis de la forma en que la percepción es categorizada e interpretada para generar información por parte del público, se centra más en el conjunto de procedimientos por los cuales se produce la instancia de interpretación que en la rigurosidad del conocimiento adquirido, para dar lugar, en todo caso, a la comprensión de la eficacia comunicativa, instalada claramente en la relación más que en las entidades comunicantes.

... "la epistemología de la relación surge como un contexto relacional ineludible. Todo este texto apunta a generar ese contexto. Si la información es la unidad mínima de idea, como sostienen Gregory Bateson (1991), la información es ecogénica por definición, la idea, según este razonamiento, es el producto emergente de actos de distinción que ejecuta el observador en su entorno. Esa visión de la idea justifica, a posteriori la consideración del vínculo observador-entorno. La idea se vuelve un a 
posteriori dentro de este esquema, y no una instancia a priori como lo es en la justificación platónica.” (Lahitte, 1996:31).

A su vez, el corpus de análisis que da cuenta del proceso de adjudicación de sentido está recortado por el discurso producido como consecuencia de la visita a la sala etnografía. Es a partir de allí, aquello que ha sido enunciado, que otorgamos algún significado a las cosas. "A los fenómenos (....) los construimos, o sea, les conferimos existencia ontológica, en definitiva, los construimos ontológicamente, al nombrarlos y al enunciarlos o representarlos. (...) lo que producimos es la existencia del fenómeno para el conocimiento. O sea, sólo se conoce lo enunciable, teniendo en cuenta que lo enunciable no equivale, sólo, a lo verbalizable, sino que abarca toda forma de enunciación semiótica, sea ésta mediante íconos, índices o símbolos; de donde surge el texto pan-semiótico.” (Magariños de Morentín, 2008:75).

Según este punto de vista, la enunciación precede a la existencia del fenómeno. La percepción es un objeto semiótico en tanto y en cuanto es identificable desde la aplicación de un conjunto de "textos pan-semióticos" "58 aprendidos socialmente.

"En mi memoria asociativa, se actualizan una serie de atractores que me permiten establecer la afinidad entre las imágenes que veo y otras imágenes con las que estoy familiarizado, que percibí históricamente. En mi estructura conceptual se asocian conceptos semánticos, percepciones visuales y ( $\sin$ agotar componentes) experiencias kinésicas, que me permiten construir con las percepciones que pude asimilar en esta situación, un referente proyectado que interpreto como para permitirme decir de él lo que escribí al comienzo de este punto: sé lo que veo porque lo sitúo como objeto actual de otras representaciones (en cuanto representamenes o signos) de las que ya tengo el hábito de interpretar mi percepción. (...) lo percibido queda así caracterizado como objeto semiótico. (... ) utilizo lo que percibo para inferir algo que no estoy percibiendo, pero que resulta inferido por mi percepción. Cuando lo que veo ya no es (sólo) un objeto semiótico, sino que se constituye en signo de otra cosa a la que accedo como interpretación de la que percibo.” (Magariños de Morentín, 2008:79).

Los productos de la observación (mensajes, datos, ideas) se recrean en el seno del marco conceptual del observador, dentro del cual se obtiene una argumentación cuya validación ya no depende del hecho de experiencia observacional vivido, el cual es 
irrepetible, sino que se vincula a los criterios básico aceptados en la producción de las argumentaciones. "El cambio de perspectiva es notorio ya que el científico deja de tomar al "método" como una receta rígida y homogeneizante, a la cual todos deben adherir. El método depende ahora de la flexibilidad de los criterios en juego dentro del marco teórico de referencia del investigador, siempre inmerso en los "hechos de experiencia” de los cuales participa. (...) La explicación científica que proponemos aquí pretende reformular el fenómeno "a explicar" en su conjunto, en su total integridad, tomando la relación como punto de partida y a las ideas que emergen del fenómeno como instancia argumental. Las ideas son el producto de la experiencia vivida, y el productor de nuevas experiencias en un bucle recursivo morfogenético. Este es nuestro ser en el mundo.”(Lahitte, 1996:36).

Las ideas, conceptos y proposiciones relevantes están disponibles en la estructura cognoscitiva del individuo y funcionan como un punto de acoplamiento con las nuevas ideas. En tal sentido el aprendizaje significativo es un aprendizaje de relaciones.

\section{V.3. La aproximación cualitativa y los estudios de recepción}

Las recientes investigaciones cualitativas sobre audiencias y comunicación de masas indican que los receptores tienen la capacidad de asignar su propio sentido a los medios de comunicación, es decir, adoptan una actitud activa en términos de capacidad selectiva y en su relación con los medios de comunicación según exposición, consumo, decodificación y usos sociales. La aproximación cualitativa permitirá, en nuestro caso, indagar acerca de las elecciones, motivos y el conjunto de asociaciones promovidas por la exhibición. En síntesis la producción de significado en el contexto de la visita. ${ }^{59}$

\footnotetext{
59 La riqueza de los mensajes propuestos reside justamente en la multiplicidad de lecturas que se atraviesan generando un campo de análisis complejo. Asimismo, la metodología propia de la etnografía es la aproximación más adecuada para este análisis. Si bien todo estudio de visitante a museo aporta elementos sustanciales para "pilotear" la institución para el mejor desarrollo de su política cultural, es necesario distinguir la evaluación del visitante en el marco de un estudio de mercado entendido como evaluación del control de calidad de la oferta y el trabajo que se quiere realizar desde un punto de vista cognitivo y semiótico con la intención de contrastar y evaluar qué y de qué modo los conceptos que guían el guión museográfico son apropiados por el visitante, de allí la importancia de pasar de una aproximación cuantitativa al terreno cualitativo.
} 
Como vimos, cada visitante trae consigo su universo cultural, expectativas, necesidades, experiencias que dan fundamento a las distintas prácticas y representaciones, de modo que la relación que establece con la propuesta expositiva (mensajes, recursos, interacciones, etc.) involucra la proyección de un conjunto de ideas que interactúan retroalimentándose con la propuesta comunicativa en la sala de exhibición.

El conocimiento de esta diversidad es fundamental a la hora de lograr cierta concordancia entre las propuestas y objetivos de la exhibición y lo que el visitante trae de su mundo cotidiano, de modo de producir un aprendizaje significativo.

Los visitantes construyen significados propios a partir de la recepción de los textos mediáticos significados acordes con sus necesidades sociales y emocionales. En este sentido, y desde el punto de vista constructivista el visitante es parte "responsable" del conocimiento que genera. Ante la propuesta del museo activa una serie de hábitos cognitivos, competencias culturales previas que le permiten interpretar el patrimonio cultural.

Conocer la interacción que puede establecer el público con los objetos de la colección y los espacios museográficos permitirá, a su vez, la interacción entre sus pensamientos y la estimulación de un proceso creativo. Estimular la reflexión, la creatividad y el sentido crítico son objetivos que permitirá a la institución museo lograr una eficiente comunicación con su público de manera de cumplir su misión educativa.

Desde un punto de vista constructivista y cognitivo, atravesado por el análisis de discurso como herramienta metodológica para el análisis, se pretende evaluar la eficacia comunicativa a partir de la construcción de un modelo que emerja de las relaciones entre el contexto de representación con el contexto de apropiación, para describir los modos de producción de sentido.

La antropología, y en particular la etnografía tienen una tradición en el uso de esta metodología de larga trayectoria. Desde sus inicios como disciplina, la observación participante, la descripción exhaustiva, el trabajo de campo y la entrevista fueron, desde distintas perspectivas teóricas, pilares en la construcción de su disciplinar.

La ventaja de la elección de una aproximación cualitativa reside, entre otras razones, en la posibilidad que esta brinda de recomponer, desde la interacción abierta, la 
visión del mundo que construye el propio actor en la situación de encuentro. Esta involucra técnicas de recolección de datos, en nuestro caso la entrevista semiestructurada, en la que las categorías descriptivas/interpretativas respecto de un referente concreto, la sala de exhibición, surgen espontáneamente en el discurso de los entrevistados.

Por otro lado, la finalidad de los estudios cualitativos escapa a la búsqueda de regularidades traducidas en resultados estadísticos, por el contrario serán identificados patrones, tendencias, jerarquías y redes conceptuales. El hecho de que las categorías de análisis no estén preestablecidas y surjan durante la investigación permite captar la diversidad y dispersión del conjunto de significados que una comunidad particular construye en un momento dado, y su eficacia simbólica. A su vez, los datos no cuantificables pueden dar una visión holística y relacional de las múltiples aristas de la experiencia humana. Interesa recuperar el significado social construido por el visitante a partir de la experiencia vivida en el recorrido de la sala teniendo en cuenta su carga emotiva, estética y simbólica.

Es posible reconocer niveles de complementariedad de ambas aproximaciones, cuantitativa y cualitativa y su adecuación a las distintas etapas de una investigación. Pero si bien el eclecticismo actual pareciera ser más fructífero que la adopción dogmática de una de ellas, es indudable que su elección está condicionada no solo a los objetivos de la investigación sino al marco epistemológico al cual se adscribe el investigador.

M. Valles analiza, según distintos criterios, las variadas perspectivas teóricoepistemológicas en las que se inscribe la aproximación cualitativa, entendiendo que la elección de la metodología tiene que ver con los procedimientos que se derivan de las posturas adoptadas en los niveles ontológico y epistemológico.

Este autor confronta distintas versiones dentro de la sociología para agrupar la diversidad de perspectivas según se opongan dos paradigmas, tres o cuatro.

Finalmente arriba a una síntesis donde compara dos posturas irreconciliables: aquella en la cual si se ha partido de una realidad "real" (objetivamente aprehensible) y una separación sujeto-objeto, la preocupación metodológica se centrará en el control experimental de posibles factores explicativos alternativos. En cambio, si el punto de partida es el de un realismo crítico ("una realidad "real" pero solo imperfectamente y 
probabilísticamente aprehensible"), y se centra la atención en la comunicación sujeto objeto, se propiciará un mayor interés por la utilización de métodos y técnicas cualitativos.

Esta síntesis de dos paradigmas opuestos en su carácter ontológico, epistemológico y metodológico involucra:

1- Paradigma prevaleciente, clásico, racionalista, positivista.

2- Paradigma emergente, alternativo, naturalista, constructivista, interpretativista, cognitivista.

"Del primero se dice que asume la existencia de una sola realidad objetiva averiguable a través de los cinco sentidos, sujeta a las leyes universales de la ciencia, y manipulable mediante procesos lógicos. El paradigma opuesto, en cambio, asumiría la existencia de realidades múltiples, con diferencias entre ellas que no pueden resolverse a través de procesos racionales o aumentando los tamaños muestrales." (Valle, 1999:53).

La ciencia del ideal realista, objetivista, determinista, se basa en el presupuesto incuestionado de una realidad per se en la que se puede "validar" toda argumentación, en tanto esa realidad se asume como mundo verdadero. En tanto presupuestos-guía, estas ideas orientan las acciones y la visión del mundo (epistemología).

"El cómo sabemos es un problema mucho más difícil. Para penetrarlo, el conocimiento debe, por así decirlo, salirse de sí mismo y observar cómo trabaja. Aquí ya no se trata pues de hechos positivos que existen independientemente de nosotros en el mundo exterior; nos encontramos frente a procesos mentales de cuyo funcionamiento no tenemos seguridad (...) nuestra imagen de la realidad no depende de lo que es exterior a nosotros, sino que inevitablemente depende también de cómo concebimos ese qué (...) la realidad supuestamente hallada es una realidad inventada y su inventor conciencia del acto de su invención, sino que cree que esa realidad es algo independiente de él, y que puede ser descubierta; por lo tanto, a partir de esa invención, percibe el mundo y actúa en él. Esa realidad construida es la realidad que nosotros creemos que nos es exterior, pero, en rigor, es un producto de nuestras propias construcciones" (Lahitte, 1996:30-31). 


\section{V.4. Condiciones del análisis}

El Museo de La Plata recibe aproximadamente más de 400 mil visitantes por año, con una gran diversidad de público respecto a edades, intereses, extracción social y procedencia. Esto asegura la continuidad, frecuencia y ampliación de la muestra según la reformulación o innovación de los intereses de la investigación. Definitivamente, la evaluación de público es una tarea constante que, en esta tesis adopta límites precisos pero siempre provisorios. En este sentido, no se pretende que los resultados constituyan un modelo único y acabado a seguir, ya que estos tendrán la especificidad vinculada al referente de análisis. Sin embargo, si se busca realizar un aporte acerca del conjunto de procedimientos lógico-empíricos, sus fundamentos teóricos $\mathrm{y}$ su aplicación metodológica y, de este modo, construir un modelo relacional entre los contextos de análisis a la vez que ofrecer un instrumento metodológico de evaluación, aportando, en consecuencia, al diseño de una política institucional en materia de exhibiciones.

Las entrevistas fueron realizadas a visitantes que recorren la sala sin la orientación por parte de un guía, los fines de semana, no contando más que con la brevísima información brindada en el folleto, de manera de minimizar, la influencia sobre el mismo.

Este relevamiento contempló una primera parte que apunta a conocer el perfil del visitante y que incluye las variables de sexo, edad, procedencia, nivel de instrucción, ocupación, grupo con quien realiza la visita.

La segunda parte consiste en preguntas generales y orientadoras con las que se busca que el visitante se explaye con libertad respecto de aquello que le interesó o llamó la atención durante la visita. Formuladas con poca variación para cada caso éstas giraron en torno a sectores, objetos y mensajes. En la mayoría de los casos no se hizo referencia a ningún sector en particular, aunque en ciertos momentos se aprovechó la disposición del visitante con preguntas específicas.

Las preguntas más amplias fueron formuladas con la intención de conocer apreciaciones generales de la sala, sectores y objetos como disparadores de los mensajes. No se incluyó en la pregunta categorías preestablecidas, es decir, por ejemplo, no se preguntó por un objeto o sector particular sino que esta referencia surgía espontáneamente en el discurso del visitante. 
El conjunto de las entrevistas permitió distinguir los lugares/espacios de sala que surgen son mayor frecuencia, así como las categorías descriptivas/interpretativas vinculadas a cada uno de los espacios/sectores/temas, así como los objetos más nombrados.

La misma nos dio la posibilidad de conocer cuáles son los puntos más destacados de la exhibición, ya sea porque han atraído más fuertemente su atención o por que han sido omitidos. En general los sectores más nombrados están asociados a cambios en la disposición conductual del visitante y recursos utilizados, generando rupturas en el recorrido.

El ámbito de las exhibiciones de museo tiene condicionamientos particulares respecto de otros estudios de tipo cualitativo, a saber, el poco tiempo de entrevista y la limitación de un único encuentro con los informantes. Sin embargo, luego de visitar la sala, el público informante expresa en una síntesis apretada y breve los tópicos de mayor impacto y más valorados durante el recorrido. El salto de la información a la conceptualización se da en aquello que le resulta más cercano a sus experiencias, expectativas, deseos, intereses o motivaciones, ligadas al momento de la vida de cada uno. Estos pueden funcionar tanto como refuerzo o como contradicción al modelo proyectado. Por otro lado hay una suerte de espontaneidad ligada a la circunstancia de la visita, generalmente entretenimiento, recreación y paseo que, sumado al anonimato de la entrevista ofrece un marco de libertad muy amplio. El visitante se expresa con libertad y generalmente con disposición.

El corpus de análisis está constituido por 150 entrevistas. Todas fueron realizadas al salir de la sala durante los fines de semana. Todas fueron sometidas al análisis de discurso aplicando la metodología propuesta por la semiótica de enunciados o simbólica, consistente en la aplicación de una serie de operaciones (normalización, segmentación, definición) que permiten recuperar la dispersión del conjunto de significados producidos por una comunidad dada a partir de una experiencia comunicativa específica. Lo efectivamente dicho en el discurso es la materia prima del análisis. ${ }^{60}$

\footnotetext{
${ }^{60} \mathrm{El}$ análisis de discurso se diferencia del análisis de contenido al no admitir conocimiento a priori de ninguna clase, en cuanto al contenido semántico del lenguaje, sino que se propone explicar, respecto de cada término, de qué modo construye tal contenido o significación en función de su uso en el contexto material y positivo en el que aparece.
} 
En relación al perfil socio demográfico se realizaron pruebas estadísticas a fin de conocer si la muestra es homogénea; es decir, si los individuos están igualmente distribuidos según los distintos criterios de clasificación. Se calcularon los valores de chi-cuadrado $(\chi 2)$ y su probabilidad con el programa Systat 10.2, para determinar la igualdad de la distribución de frecuencias según las distintas variables (Blalock, 1986). Como criterio para rechazar las hipótesis nulas de igualdad de las frecuencias se tomó un nivel de significación de 0,05 . Esto indica que todo valor de $\chi^{2}$ con probabilidad mayor a 0,05 indica que las hipótesis nulas no pueden ser rechazadas y que las frecuencias no difieren significativamente (Blalock, 1986).

Los resultados indicaron que en la mayoría de las comparaciones, los valores $\chi^{2}$ no resultaron significativos. Es decir, los individuos se distribuyeron homogéneamente de acuerdo a los criterios de clasificación indagados y, en general, la composición de la muestra utilizada puede considerarse balanceada.

Las únicas comparaciones que indican que no hay igualdad en las frecuencias y en las que las hipótesis nulas fueron rechazadas son: ocupación vs sexo y grupo etáreo vs nivel de instrucción. En la primera de ellas, la heterogeneidad de las frecuencias se produce principalmente porque la categoría "amas de casa" tiene alta frecuencia en el sexo femenino $(\mathrm{n}=14)$ y ningún miembro del sexo masculino. En la segunda comparación, los individuos se reparten en gran número de grupos etáreos. Además, el máximo nivel de instrucción alcanzado varía mucho de acuerdo a las edades. En el grupo de 16 a 25 años, la gran mayoría de los individuos presenta el nivel universitario incompleto; en el grupo de 26 a 35 años son frecuentes los individuos de nivel universitario o secundario completo, así como los de universitario incompleto; en tanto que los grupos etáreos mayores hay pocos individuos representando de modo bastante uniforme casi todos los niveles de instrucción.

\section{V.5. La semiótica y el análisis de discurso}

Ante la diversidad de abordajes y el aporte del análisis de discurso a las ciencias sociales, en los años sesenta autores como Van Dijk desarrollan la tendencia hacia un análisis de discurso integrador de las pluralidades de desarrollos teóricos y metodológicos, existentes dentro y fuera de las ciencias sociales, aprovechables en la investigación social. El análisis del discurso es un campo de estudio nuevo, 
interdisciplinario, que ha surgido a partir de algunas disciplinas de las humanidades y de las ciencias sociales como la lingüística, los estudios literarios, la antropología, la semiótica, la sociología y la comunicación oral. La semiótica primera se ha desarrollado, diversificándose en un conjunto de metodologías orientadas al estudio de la producción, circulación e interpretación del sentido en contextos enunciativos determinados, pasando del análisis de los códigos a la semiótica de los procesos de inter subjetividad e intertextualidad. (Valles, 1999).

La comunicación, los intercambios comunicativos, ya no se conciben como una mera transferencia de información (mensajes) desde un emisor a un recepto (proyectando la racionalidad instrumental de la ingeniería sobre los procesos de la semiosis social). Lo que hay en circulación son conjuntos de textos. No se da una comparación de mensajes con códigos, sino con conjuntos de prácticas textuales o discursivas. De modo que no es un único mensaje el que se recibe o se emite, sino muchos, tanto en sentido sincrónico como diacrónico.

La semiótica como disciplina nos proporciona un conjunto de instrumentos teórico/empíricos para implementar en el análisis un método preciso y "explicar" el proceso de producción, comunicación y transformación del significado en el campo de las ciencias sociales Esta metodología ofrece un conjunto de operaciones cognitivas rigurosas que permiten dar cuenta de los procedimientos analíticos aplicados en la investigación. La rigurosidad aludida refiere a la posibilidad de recuperar los pasos seguidos que deberán ser explicitados, es decir, el conjunto de operaciones/proposiciones intermedias que recursivamente conectan las proposiciones iniciales (el punto de partida) y las proposiciones finales o interpretación.

El análisis de lo que hemos denominado el contexto de apropiación se enmarca dentro de la semiótica simbólica, dado que el corpus está conformado por los discursos lingüísticos producidos por los visitantes como resultado de la visita a la sala.

Desde esta perspectiva se pretende dar cuenta del proceso socio cognitivo de producción de la significación vigente de determinado fenómeno social. En nuestro caso, la significación producida a partir de la visita a la sala.

En este punto, son necesarias ciertas aclaraciones de orden epistemológico propuestas por esta disciplina. Las operaciones no proponen ningún conjunto previo de 
entidades ni de configuraciones entre tales entidades, sino que éstas son el producto construido por el propio visitante y materializado en la enunciación (o en el discurso).

"El campo de los acontecimientos discursivos, en cambio, es el conjunto siembre finito y actualmente limitado de las únicas secuencias lingüísticas que han sido formuladas, las cuales pueden muy bien ser innumerables, pueden muy bien, por su masa, sobrepasar toda capacidad de registro, de memoria o de lectura, pero constituyen no obstante, un conjunto finito (...) La descripción de los acontecimientos del discurso plantea otra cuestión muy distinta: ¿cómo es que ha aparecido tal enunciado y ningún otro en su lugar? (...) El análisis del campo discursivo (...) trata de captar el enunciado con la estrechez y la singularidad de su acontecer; de determinar las condiciones de su existencia, de fijar sus límites de la manera más exacta, de establecer sus correlaciones con los otros enunciados que pueden tener vínculos con él, de mostrar qué otras formas de enunciación excluye.” (Foucault, 2002:45).

Permite la identificación de formaciones discursivas, es decir " el principio de dispersión y de repartición, no de las formulaciones, no de las frases, no de las proposiciones, sino de los enunciados (en el sentido que he dado a esta palabra), el término de discurso podrá quedar fijado así: conjunto de los enunciados que dependen de un mismo sistema de formación, y así podré hablar del discurso clínico, del discurso económico, del discurso de la historia natural, del discurso psiquiátrico." (Foucault, 2002:181).

A partir de la semiótica de enunciados es posible aplicar el conjunto de operaciones que permitirán, a posteriori, representar o recuperar los mundos semióticos posibles en una determinada comunidad en un momento dado.

Las formaciones discursivas son el producto textual de las operaciones cognitivas socialmente adquiridas a partir de las cuales se construyen los significados de los mundos semióticos posibles.

"la operación explora las posibilidades organizacionales de un conjunto de relaciones contextuales, identificables entre las entidades físicas componentes de un determinado fenómeno social, así como las relaciones posibles de tal fenómeno con los otros fenómenos constitutivos de su entorno social e histórico." (Magariños de Morentín, 2008:157). 
La operación se inicia en la identificación, a partir de una base sintáctica, las relaciones posibles entre las entidades físicas enunciadas, (de manera icónica, indicial o simbólica) en nuestro caso simbólica, las cuales no preexisten al discurso sino que éste le otorga carácter óntico. A partir de allí, mediante las operaciones de contextualización aparece el proceso de producción (atribución), las condiciones de interpretación (sustitución) y las posibilidades de transformación (superación). ${ }^{61}$

Esta metodología participa a su vez de una propuesta constructivista. El observador/analista construye su objeto de estudio a partir de estas atribuciones diferenciales.

El análisis textual permitirá:

-acceder al significado que adquiere el objeto de cual se habla, que no preexiste al discurso, el cual deja de ser lo que es en sí para que otra semiosis lo constituya;

-establecer el significado del sujeto plural que no preexiste al discurso y que se construye en lo que resulta identificable en sus modalidades discursivas;

-acceder al significado de los conceptos que se utilizan en los correspondientes textos y que no preexisten al discurso, pues su eficacia significativa proviene del contexto en el que aparecen.

Asumir este modelo de análisis para el caso que nos ocupa tiene implicancias teórico metodológicas que pueden ser enunciadas como los siguientes principios:

- la sala etnografía es el producto de la interpretación de un sujeto colectivo y puede ser concebida en su textualidad, es decir, constituida por un conjunto de relaciones formales (sintaxis simbólica), configuración (icónica) o disposición (indicial) y como tal susceptible de ser interpretada;

- este texto es entonces productor de interpretaciones dado que atribuye determinado significado a un ente, en nuestro caso las interconexines entre los objetos, las imágenes,

\footnotetext{
${ }^{61}$ Este procedimiento proporciona la explicación acerca de la semiosis disponibles en una sociedad. Las operaciones semióticas fundamentales son: "las de atribución (de un valor a una forma; identificación de un objeto semiótico por las relaciones sintácticas o contextuales), sustitución (o interacción entre una semiosis sustituyente y otra semiosisi sustutuida); semantización de un objeto semiótico por parte de su contraste diferencial) y superación (de las contradicciones evidenciales por la aplicación de las precedentes semiosis sustitiuyete y sustituida, con la posible emergencia de un nuevo lenguaje; historicidad del objeto semiótico en función de la pragmática de su enunciación." (Magariños de Morentín, 2008:157).
} 
los textos, y los recursos expositivos y su configuración particular en la sala de exhibición motivo de este estudio;

- para, finalmente dar cuenta de los distintos conjuntos temáticos aludidos durante el recorrido y su organización por inclusión y contraste.

El "texto sala", entendido como contexto de representación, es el resultado de los recortes, intenciones, objetivos e interpretaciones por parte de los curadores de los discursos etnográficos disciplinares producidos, en la mayoría de los casos a partir de una situación de contacto. El curador (museólogo, antropólogo) sistematiza, sintetiza y construye a su vez un discurso a partir de un conjunto de entidades (las colecciones) a las cuales les otorga su carácter de existente dentro del nuevo contexto (sintáctico, semántico y pragmático) transformándolo en objeto museable.

En consecuencia las entrevistas y su análisis permiten recuperar/ registrar los esquemas interpretativos dispersos y vigentes producidos como resultado de la visita a la sala. Permiten identificar la presencia de estructuras formales por oposición o diferencia. En el análisis semiótico no se trata de una operación probabilística de dimensión cuantitativa, sino de registrar al menos una contradicción. Si no identificáramos en el análisis al menos una contradicción la muestra es insuficiente ya que no alcanza a dar cuenta de la pluralidad inherente a cualquier sociedad. Es decir, del conjunto de operaciones aplicadas a discursos del visitante se infieren los distintos esquemas interpretativos vigentes. A partir de la interpretación elaborada, un nuevo texto, se recuperan los mundos semióticos posibles.

El tratamiento es cognitivo en la medida en que tiene que dar cuenta de cómo está operando la mente de cada intérprete, con los instrumentos que le proporciona su cultura a partir de su estructura neurológica filogenética, en la configuración de los correspondientes signos, cuya enunciación atribuirá existencia ontológica a los aspectos del entorno que por su intermedio podrán ser percibidos e interpretados.

“La palabra cognición (...) en sentido figurado significa aquello que es configurado, aquello que co-contruimos. Los conocimientos se organizan y estructuran o, en términos de Denis (1984), se definen funciones referenciales y funciones elaboradas que permiten la formación de las imágenes. (...) Sin embargo, debe quedar en claro que nosotros no somos conscientes del proceso por el cual estas imágenes se 
forman. Sabemos que formamos imágenes, sabemos qué imágenes formamos, pero no sabemos cómo. Las imágenes siempre son retrospectivas.

(...) La antropología cognitiva sostiene que, primeramente, no hay un pensamiento individual independiente del contexto eco-cultural. Las secuencias cognitivas se construyen en, y con, el comienzo mismo del pensamiento (proceso mental). La cognición describe, de este modo, un devenir de los contenidos de la mente. En la medida en que todo pensamiento humano (provenga de la cultura que provenga) es concreto (en el sentido que se refiere a cosas asignable, cosas en foco), la referencialidad pasa a ser un conditio sine qua non del funcionamiento del intelecto. En relación a la aproximación psicológica, la aproximación cognitiva en antropología no se ocupa, tampoco, de las formas patológicas del pensamiento, por el contrario, trata las configuraciones del pensamiento sobre la base de construcciones, e interpretaciones, igualmente posibles, de las cuales algunas de ellas logran su realización.” (Lahitte, 1996:56).

Finalmente, la significación consiste en aquella representación de un concreto fenómeno social materializada (o materializable) mediante una determinada semiosis en cuanto propuesta perceptual, acerca de la forma posible de su existencia, dirigida a la comunidad que le confiere, a tal fenómeno, una determinada existencia cognitiva.

Asumido este punto de partida nos incluimos en el campo de la semiótica simbólica y el análisis de discursos. Se entiende por semiótica simbólica o semiótica de enunciados a aquella metodología de investigación destinada a explicar el significado de determinados fenómenos sociales cuando su representación/interpretación ha sido socialmente producida por textos simbólicos. Para nosotros, los discursos producidos por el visitante. ${ }^{62}$

Al producir los discursos se construyen las entidades (objetos, conceptos, fenómenos sociales) representadas en la materialidad textual y, en consecuencia, interpretadas. El trabajo metodológico consiste en identificar y recuperar su significado contrastantemente, es decir, por diferencia. Se busca mostrar la dispersión de interpretaciones y no la interpretación verdadera.

El método propuesto consiste en un conjunto de operaciones concretas, sistematizadas y estandarizadas, siendo las entrevistas la materia prima del análisis. El

\footnotetext{
${ }^{62}$ En el sentido pierceano textos simbólicos designan predominantemente el habla.
} 
discurso recuperado es concebido como "la representación de la configuración diferencial de dicho universo de valores y conceptos tal como aparece efectivamente enunciado en determinado corpus de discursos, es el objetivo específico al que aporta sus operaciones analíticas esta metodología semiótica” (Magariños de Morentín, 2008:179).

\section{V.6. Las operaciones analíticas}

Todas las entrevistas fueron desgrabadas y analizadas a partir de tres tipos de operaciones: normalización, segmentación e identificación de las definiciones contextuales.

La normalización es el punto de inicio del procedimiento. Esta operación tiene por objeto recuperar omisiones, implícitos sintácticos, expresiones truncadas, propias del discurso oral. El tipo de intervención será siempre registrada gráficamente y no incorpora términos o expresiones no dichas por el entrevistado.

A partir de aquí, será posible identificar las partes de un texto que se consideran básicas o elementales, es decir unidades semánticas, con sentido que serán analíticamente diferenciadas en segmentos y que contiene el conjunto de relaciones necesarias pero no suficientes para la construcción de significado. El criterio de base es sintáctico. Luego, podrán recuperarse las definiciones contextuales, es decir, establecer las características de la construcción semántica de determinados nombres en función de los contextos en que los ha utilizado su productor.

"La definición contextual es aquella mediante la cual se establece el sentido que adquiere un término cualquiera, presente en determinado segmento textual completo, en función del contexto al que dicho término aparece asociado en ese mismo segmento." (Magariños de Morentín, 2008: 178).

Por último a partir de un determinado repertorio de definiciones contextuales se identifican los ejes conceptuales por los cuales se agrupan dichas definiciones, para dar cuenta de los distintos modos de atribuir significado a los correspondientes términos. El análisis diferencial permite recuperar los discursos vigentes a partir de su organización en redes contrastantes o secuencias.

La presencia de la diferencia o de la contradicción es condición necesaria pero no suficiente para afirmar la representatividad de la muestra sometida a análisis. 
De no surgir nuevas diferencias, el análisis se valida por saturación. En realidad la producción discursiva no tiene jamás un límite, siempre será posible la aparición de una nueva formación, sin embargo, para nuestro objetivo, el grado de saturación es un indicador importante.

A continuación se presentan ejemplos de aplicación de las operaciones analíticas.

\section{Encuesta $N^{o} 5$}

MM: Comienza haciendo una breve referencia a la inauguración de la sala. Queremos ver que opina el público en general, si le gustó...

E: Si, la primera impresión me llamó la limpieza, el piso, todo eso, que deja una impresión...

MM: De nuevo.

E: Sí, sí, sí, de nuevo parecía. Sí. No, bien, bien. Fue una de las que más le prestamos atención. Por ahí porque es más cercana a nosotros, no sé. Más de esta época, no tan lejana.

MM: No tan lejana. No son los dinosaurios, ¿no es cierto? (Risas).

E: Y nos llamaba la atención lo último, que no dice, pero bueno, me imagino que es como viven una persona afuera o de estas últimas épocas.

MM: De estas últimas épocas...

E: Porque tenía hasta el celular con la tarjeta, todo. Un detalle muy, muy bueno. El póster de Maradona. Me gustó eso.

MM: Claro ¿Sentiste en algún momento que tiene que ver con nosotros?

E: Sí, sí, sí.

MM: ¿Sos de acá, de...?

E: De Buenos Aires.

MM: Y... ¿Los textos? ¿Cómo te resultaron los textos?

E: No, bien. Es entendible, todo.

MM: ¿Y el último sector de las máscaras? 
E: Está piola, está piola. No sabía que miraban. Veía a todos que miraban pero no me daba cuenta que era, hasta que miré que me estaban espiando. (Risas)

MM: ¿Te deja algún mensaje la sala? si tuvieras que decir algo que te inspire, así... esto es anónimo, vos podés decir lo que quieras, si te ...

E: No, si. Como mensaje, no, pero, qué sé yo, como para recomendar "andá arriba", que sé yo, a alguien que venga o venir en otra oportunidad, o "vení, porque hay una sala así y así que me gustó”...

MM: Te gustó, por sobre todo te gustó.

E. Sí, sí, sí. Me gustó.

MM: ¿Alguna pieza en particular, que recuerdes así...?

E: no. Los botes, nos llamó la atención. Cómo estaba trabajado eso.

MM: Claro. Sí, impresionante.

E: Sí, muy trabajado.

MM: Bueno. Muchísimas gracias.

Continúa la grabación con el perfil del entrevistado.

\section{Normalización}

(+ a mi) la primera impresión me llamó la limpieza, (= de la sala) (+ a mi) (=me llamó la atención) el piso (=de la sala), todo eso, que deja una impresión (+nosotros) (=la sala) fue una de las que más le prestamos atención (+nosotros) (= le prestamos más atención) (=a la sala) Por ahí porque es más cercana a nosotros (+ para nosotros) es Más de esta época (=la sala) (+para nosotros) (=la sala) [*no es] tan lejana (+a nosotros) (=de la sala) nos llamaba la atención lo último [el escenario] (+yo) me imagino que [el escenario] (=de la sala) es como viven una persona afuera (+yo) (=me imagino que [el escenario] (=de la sala) (=es como vive una persona ) de estas últimas épocas (+yo) [pienso] (=de estas últimas épocas) Porque tenía hasta el celular con la tarjeta [el escenario] (=de la sala) (+yo) [pienso](=de estas últimas épocas) (=porque tenía) todo[el escenario] (=de la sala) (+yo) [pienso] [*que] detalle muy, muy bueno. El póster de Maradona. (+a mi) Me gustó eso (=el poster de Maradona) [del escenario] (=de la sala) (+para mí) (=los textos) (=de la sala) (=me resultaron) bien. (+para mí) (=los 
textos) (=de la sala) Es entendible (+para mí) (=es entendible) (=de la sala) todo (+para mí) (=el sector de las máscaras) Está piola (+yo) (=en el sector de las máscaras) (=de la sala) No sabía que miraban. (+yo) (=en el sector de las máscaras) (=de la sala) Veía a todos que miraban pero no me daba cuenta que era ( + yo) (=no me daba cuenta que era) hasta que miré que me estaban espiando (=en el sector de las máscaras) (=de la sala) (+a mí) (=la sala) como mensaje no (=me dejó) [nada] pero (+para mí) (=la sala) [ es] como para recomendar "andá arriba" a alguien que venga (+para mí) )(=la sala) es para venir en otra oportunidad, (+a mí) (=la sala) me gustó ( + a mí) (=me gustó) (=en particular) Los botes (=de la sala) (+a nosotros) nos llamó la atención como estaba trabajado $(=$ los botes $)(=$ de la sala) $(+$ a nosotros $)(=$ nos pareció impresionante $(=$ como estaba trabajado $)(=1$ los botes $)(=$ de la sala $)$.

\section{Segmentación}

1. (+ a mí) la primera impresión me llamó la limpieza (= de la sala)

2. (+ a mí) (=me llamó la atención) el piso (=de la sala)

3. (+nosotros) (=la sala) fue una de las que más le prestamos atención

4. (+nosotros) $(=$ le prestamos más atención) Por ahí porque es más cercana a nosotros-

5. (+para nosotros) (=la sala) es Más de esta época

6. (+para nosotros) (=la sala) [*no es*] tan lejana

7. (+a nosotros) nos llamaba la atención lo último [el escenario] (=de la sala)

8. (+yo) me imagino que [el escenario] (=de la sala) es como viven una persona afuera

9. $(+$ yo) $(=$ me imagino que [el escenario] (=de la sala) $(=$ es como vive una persona ) de estas últimas épocas

10. (+yo) (=me imagino) (=de estas últimas épocas) Porque tenía hasta el celular con la tarjeta [el escenario] (=de la sala)

11. (+yo) (=me imagino) (=de estas últimas épocas) (=porque tenía) todo [el escenario] (=de la sala)

12. (+para mí) es un detalle muy, muy bueno. El póster de Maradona [del escenario] (=de la sala)

13. (+a mí) Me gustó eso (=el poster de Maradona) [del escenario] (=de la sala) 
14. (+para mí) (=los textos) (=de la sala) (=me resultaron) bien

15. (+a mí) (=los textos) (=de la sala) Es entendible

16. (+para mí) (=es entendible) (=de la sala) todo

17. (+para mí) (=el sector de las máscaras) (=de la sala) Está piola

18. (+yo) (=en el sector de las máscaras) (=de la sala) No sabía que miraban

19. (+yo) (=en el sector de las máscaras) (=de la sala) Veía a todos que miraban pero no me daba cuenta que era

20. $(+$ yo) (=no me daba cuenta que era) hasta que miré que me estaban espiando (=en el sector de las máscaras) (=de la sala)

21. (+a mí) (=la sala) como mensaje no (=me dejó) [nada] pero

22. (+para mí) (=la sala) [ es] como para recomendar "andá arriba" a alguien que venga

23. (+para mí) )(=la sala) es para venir en otra oportunidad

24. (+a mí) (=la sala) me gustó

25. (+a mí) (=me gustó) (=en particular) Los botes (=de la sala)

26. ( + a nosotros $)$ nos llamó la atención como estaba trabajado ( $=\operatorname{los}$ botes) $(=$ de la sala)

27. ( + a nosotros) (=nos pareció impresionante (=como estaba trabajado)(=los botes) $(=$ de la sala $)$.

\section{Definiciones contextuales:}

1. (=la sala) es aquella que ( + a mí) la primera impresión me llamó la limpieza

2. (=la sala) es aquella que (+ a mí) (=me llamó la atención) el piso

3. (=la sala) es aquella a la que (+nosotros) más le prestamos atención

4. (= la sala) es aquella a la que (+nosotros) (= le prestamos más atención) porque es más cercana a nosotros-

5. (=la sala) es aquella que para (+nosotros) es Más de esta época

6. (=la sala) es aquella que (+para nosotros) [* no es*] tan lejana

7. a- (=la sala) es aquella que (+a nosotros) nos llamaba la atención lo último [el escenario]

b- [el escenario] es aquello último $(=$ de la sala) que (+a nosotros) nos llamaba la atención 
8. [el escenario] (=de la sala) es aquel del que (+yo) me imagino que es como vive una persona afuera

9. [el escenario] (=de la sala) es aquel del que $(+$ yo) $(=$ me imagino que es como vive una persona ) de estas últimas épocas

10. [el escenario] (=de la sala) es aquel del que (+yo) (=me imagino) (=de estas últimas épocas) Porque tenía hasta el celular con la tarjeta

11. [el escenario] (=de la sala) es aquel que $(+$ yo) $(=$ me imagino) $(=$ de estas últimas épocas) (=porque tenía) todo

12. a- El póster de Maradona es aquel que (+para mí) es un detalle muy, muy bueno [del escenario] (=de la sala)

b- [el escenario] (=de la sala) es aquel en el que el póster de Maradona es aquel que (+para mí) es un detalle muy, muy bueno

13. a- (=el poster de Maradona) es eso que (+a mí) Me gustó [del escenario] (=de la sala)

b- [el escenario] (=de la sala) es aquel en el que (+a mí) me gusto el poster de Maradona

14. (=los textos) (=de la sala) son aquellos que (+a mí) (=me resultaron) bien

15. (=los textos) (=de la sala) son aquellos que (+para mí) Es entendible

16. (= la sala) es aquella que (+para mí) (=es entendible) todo

17. (=el sector de las máscaras) (=de la sala) es aquel que (+para mí) Está piola

18. (= el sector de las máscaras) (=de la sala) es aquel del que (+yo) No sabía que miraban

19. (=el sector de las máscaras) (=de la sala) es aquel en el que (+yo) Veía a todos que miraban pero no me daba cuenta que era

20. (= el sector de las máscaras) (=de la sala) es aquel en el que $(+$ yo) $(=$ no me daba cuenta que era) hasta que miré que me estaban espiando

21. (=la sala) es aquella que ( + a mi) como mensaje no (=me dejó) [nada]

22. (=la sala) es aquella que (+para mí) [ es] como para recomendar "andá arriba" a alguien que venga

23. (=la sala) es aquella que (+para mí) ) es para venir en otra oportunidad

24. (=la sala) es aquella que ( + a mí) me gustó

25. (=la sala) es aquella de la que (+a mí) (=me gustó) (=en particular) Los botes 
26. a- (=la sala) es aquella de la que (+a nosotros) nos llamó la atención como estaban trabajados (=los botes)

b- (=los botes) (=de la sala) son aquellos de los que (+a nosotros) nos llamó la atención como estaban trabajados

27. a- (=la sala) es aquella de la que (+a nosotros) (=nos pareció impresionante $(=$ como estaban trabajados $)(=$ los botes $)$

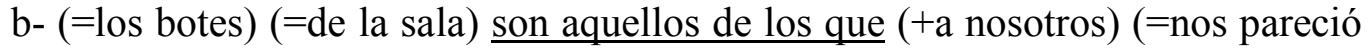
impresionante) (=como estaban trabajados)

\section{Entrevista $N^{o} 12$}

MM: Trabajamos en el Museo y estamos haciendo una evaluación de público, ya que esta sala se inauguró recientemente, a ver qué les gustó más, si les gustó...

E: Me gustó mucho el Museo, todo en general. Muy sorprendido, hace tanto que no venía; pero lo veo muy interesante, muy remozado. Muy interesante ¿De esta sala en especial?

MM: Sí.

E: Y si, es como un pedazo de la tierra donde nosotros vivimos, no? Me fascinaron las canoas, cómo vivían los antepasados, no? Más que, la situación de pensar desde los colonizadores, no? Yo toco la guitarra y me fui a ver la guitarra que habían traído de Europa. También vi el violonchelo, cómo lo habían cortado. Me pareció hermoso, muy interesante. La verdad que a mí me gustó mucho.

MM: Bueno, ¿te tomamos los datos?

\section{Normalización:}

(+a mí) Me gustó mucho el Museo (+a mí) (=me gustó) (=del museo) todo en general $(+$ yo) [estoy] Muy sorprendido (=del museo) (+yo) hace tanto que no venía (=al museo) $(+\mathrm{yo}) \mathrm{veo}(=\mathrm{al}$ museo $)$ muy interesante $(+\mathrm{yo})(=\mathrm{veo})(=\mathrm{al}$ museo $)$ muy remozado $(+$ para mí) (=esta sala) es como un pedazo de la tierra donde nosotros vivimos (+a mí) (=de esta sala) Me fascinaron las canoas ( $+\mathrm{a} \mathrm{mi})$ (=de esta sala) (=me fascinaron) cómo vivían los antepasados (+a mí) (=de esta sala) (=me fascinó) la situación de pensar desde los colonizadores. Yo toco la guitarra y me fui a ver (=en la sala) la guitarra que habían traído de Europa. (+yo) También vi (=en la sala) el violonchelo (+yo) vi (=del 
violonchelo) cómo lo habían cortado ( $+\mathrm{a}$ mi) (=el violonchelo) Me pareció hermoso (+a mi) (=la sala) (=me pareció) muy interesante. La verdad que a mí (=la sala) me gustó mucho.

\section{Segmentación:}

1. (+a mí) Me gustó mucho el Museo

2. (+a mí) (=me gustó) (=del museo) todo en general

3. (+yo) [estoy] Muy sorprendido (=del museo)

4. (+yo) hace tanto que no venía (=al museo)

5. $(+$ yo $)$ veo(=al museo $)$ muy interesante

6. $(+\mathrm{yo})(=\mathrm{veo})(=\mathrm{al}$ museo $)$ muy remozado

7. (+para mí) (=esta sala) es como un pedazo de la tierra donde nosotros vivimos

8. (+a mí) (=de esta sala) Me fascinaron las canoas

9. (+a mí) (=de esta sala) (=me fascinaron) cómo vivían los antepasados

10. (+a mí) (=de esta sala) (= me fascinó) la situación de pensar desde los colonizadores

11. Yo toco la guitarra y me fui a ver (=en la sala) la guitarra que habían traído de Europa

12. (+yo) También vi (=en la sala) el violonchelo

13. $(+$ yo) vi (=del violonchelo) cómo lo habían cortado

14. (+a mí) (=el violonchelo) Me pareció hermoso

15. (+a mí) (=la sala) (=me pareció) muy interesante

16. a mí (=la sala) me gustó mucho

\section{Definiciones contextuales:}

1. el museo es aquel que (+a mí) Me gustó mucho

2. (=el museo) es aquel que ( + a mí) (=me gustó) todo en general

3. (=el museo) es aquel del cual (+yo) \{estoy\} Muy sorprendido

4. (=el museo) es aquel al que (+yo) hace tanto que no venía

5. (=el museo) es aquel al que (+yo) veo muy interesante

6. (=el museo) es aquel al que (+yo) (=veo) muy remozado

7. (=esta sala) es aquella que (+para mí) es como un pedazo de la tierra donde nosotros vivimos 
8. (=la sala) es aquella de la que (+a mí) Me fascinaron las canoas

9. (=la sala) es aquella de la que (+a mí) (=me fascinaron) cómo vivían los antepasados

10. (=la sala) es aquella de la que (+a mí) (= me fascinó) la situación de pensar desde los colonizadores

11. (=la sala) es aquella en la que me fui a ver la guitarra que habían traído de Europa [*porque*] Yo toco la guitarra

12. (=la sala) es aquella en la que (+yo) También vi el violonchelo

13. (=el violonchelo) es aquel del que (+yo) vi cómo lo habían cortado

14. (=el violonchelo) es aquel que (+a mí) Me pareció hermoso

15. (=la sala) es aquella que (+a mí) (=me pareció) muy interesante

16. (=la sala) es aquella que a mí me gustó mucho 


\section{Capítulo VI \\ LAS DEFINICIONES CONTEXTUALES \\ Y LOS MUNDOS SEMIÓTICOS POSIBLES}




\section{Capítulo VI: Las definiciones contextuales y los mundos semióticos posibles}

\section{VI.1. Los procedimientos analíticos}

En este capítulo se hará referencia a los procedimientos que dan cuenta del recorrido analítico aplicado al conjunto de definiciones contextuales. Organizadas según un conjunto de nodos, la dispersión de las categorías referenciadas en un mismo objeto, recurso o tema, darán lugar a la configuración de los mundos semióticos posibles, producto de la experiencia concreta de la visita a la sala de exhibición. Una vez aplicadas las operaciones analíticas (normalización, segmentación y definición), el corpus queda conformado por el conjunto total de definiciones contextuales, es decir, las estructuras textuales mínimas sintáctica y semánticamente completas y cuya agrupación dará lugar a las redes contrastantes o mundos semióticos posibles.

El siguiente paso es el de agrupar las definiciones según descriptores o nodos. Estos son conjuntos identificables como colectores de una mismo tipo de información. Si bien su identificación no es ingenua, ya que responde a los objetivos e intereses que sustentaron la innovación de la sala, ya explicitados, durante el análisis surgen nuevas categorías, de manera que toda definición contextual formará parte al menos de uno de los nodos, pudiendo formar parte de más de un nodo.

Inicialmente se ensayó una primera agrupación según los siguientes ítems:

- cuando el entrevistado refiere en forma implícita y /o explícita a los sujetos productores de aquello concebido como referente de la enunciación,

- cuando el entrevistado alude al presente, y el conjunto de referentes que disparan dicha enunciación,

- cuando es posible recuperar un concepto de cultura/identidad,

- cuando al objeto nombrado se le adjudica un valor,

- cuando el visitante se refiere a su mundo cotidiano, hay una suerte de autoreferencialidad.

El procedimiento analítico incorpora el análisis comparativo de manera de agrupar las distintas definiciones contextuales por contraste o afinidad. A su vez, el análisis al interior de cada nodo o apartado permitirá nuevos niveles de contrastación/inclusión o tipo lógico. Este procedimiento también es denominado como 
método comparativo constante. A diferencia de la inducción analítica, este método se caracteriza, en primer lugar, en que no se ocupa de testar provisionalmente sino de generar categorías conceptuales, sus propiedades (aspectos significativos de las categorías) y las hipótesis (o relaciones entre ellas). En segundo lugar, las propiedades no son únicamente causales, como en la inducción analítica, sino condiciones, consecuencias, dimensiones, tipos, procesos, etc. Asimismo, no hay un intento de verificar la universalidad ni la prueba de causas sugerida $\mathrm{u}$ otras propiedades. $\mathrm{Y}$ al no haber prueba, este procedimiento -a diferencia de la inducción analítica- requiere de la "saturación" de la información. El objetivo no es tanto la verificación como la generación de la teoría. Por último, se lo considera más aplicable a cualquier tipo de información cualitativa (observaciones, entrevistas, documentos, etc.) dentro de un mismo estudio (Valles, 1999).

El proceso en marcha de categorización abierta estimula el descubrimiento no sólo de categorías sino también de sus propiedades y dimensiones. La agrupación de definiciones contextuales y la configuración de nodos y sus niveles de inclusión fue informatizado a través de la aplicación del programa para datos cualitativos $\mathrm{N}$ Vivo, versión 1.3. ${ }^{63}$ El desarrollo de paquetes informáticos específicos para el análisis cualitativo exige al investigador la externalización de los procesos intelectuales que tienen lugar en las distintas fases del análisis. ${ }^{64}$ Una vez organizada la información e incorporada al programa, éste permite establecer, múltiples relaciones y la modelización de los datos según distintos formatos.

\footnotetext{
${ }^{63}$ El Copy Right de la empresa QSR (Qualitative Solutions and Research).

64 "El desarrollo de programas generales y especializados útiles para el análisis cualitativo presenta las siguientes ventajas: haber sido diseñados, específicamente, para imitar y superar los procedimientos manuales; ayudar al investigador a marcar fragmentos de texto, codificarlos y recodificarlos durante el desarrollo de un índice o sistema organizados; la asignación de uno o varios códigos a un fragmento textual se hace fácilmente y el programa adjunta a cada fragmento extractado el documento original, la identificación correspondiente; la búsqueda y recuperación en pantalla o impresora de todos los fragmentos codificados de igual modo para proceder a su inspección conjunta; el apoyo a la elaboración conceptual y teórica, mediante utilidades de formulación y comprobación de hipótesis; algunos paquetes sobresalen por la ayuda que prestan en la elaboración teórica, mediante la confección de redes conceptuales; permiten recuperar una gran cantidad de información y modelizarla para una mejor visualización de las relaciones." (Valles, 1999:395).
} 


\section{VI.2. Organización de la enunciación: variables, nodos y redes}

La distinción de clase más abarcativa es la que alude a la definición de museo. Esta surge con espontaneidad ya que la entrevista no incluye una pregunta sobre el tema, pues escapa a los intereses específicos de la misma, focalizada en la sala. Uno de las variables que configura esta categoría se relaciona con la frecuencia de la visita. Los entrevistados tienen una fuerte vinculación con el museo asociada a la infancia/niñez, siendo el museo un lugar al que no han vuelto desde entonces. La motivación para regresar se encuentra en los chicos, (hijos, sobrinos, amigos). Aquí toma fuerza la autoreferencialidad, la experiencia personal y el recuerdo.

Por otro lado, la definición referencial del museo y por la cual el visitante le otorga identidad, encierra una comparación según distintas variables tales como:

- la ubicación espacial: las salas de arriba/ las salas de abajo,

- los temas abordados: los animales/ las culturas autóctonas,

- el estado de conservación y puesta museográfica: las salas nuevas/ las salas viejas.

Otra de las categorías que hemos podido reconocer incluye apreciaciones generales, tanto positivas como negativas. Estas abarcan desde condiciones físicas como la limpieza hasta las motivaciones de la visita, generalmente adjetivada.

El siguiente esquema expresa las relaciones entre los nodos:

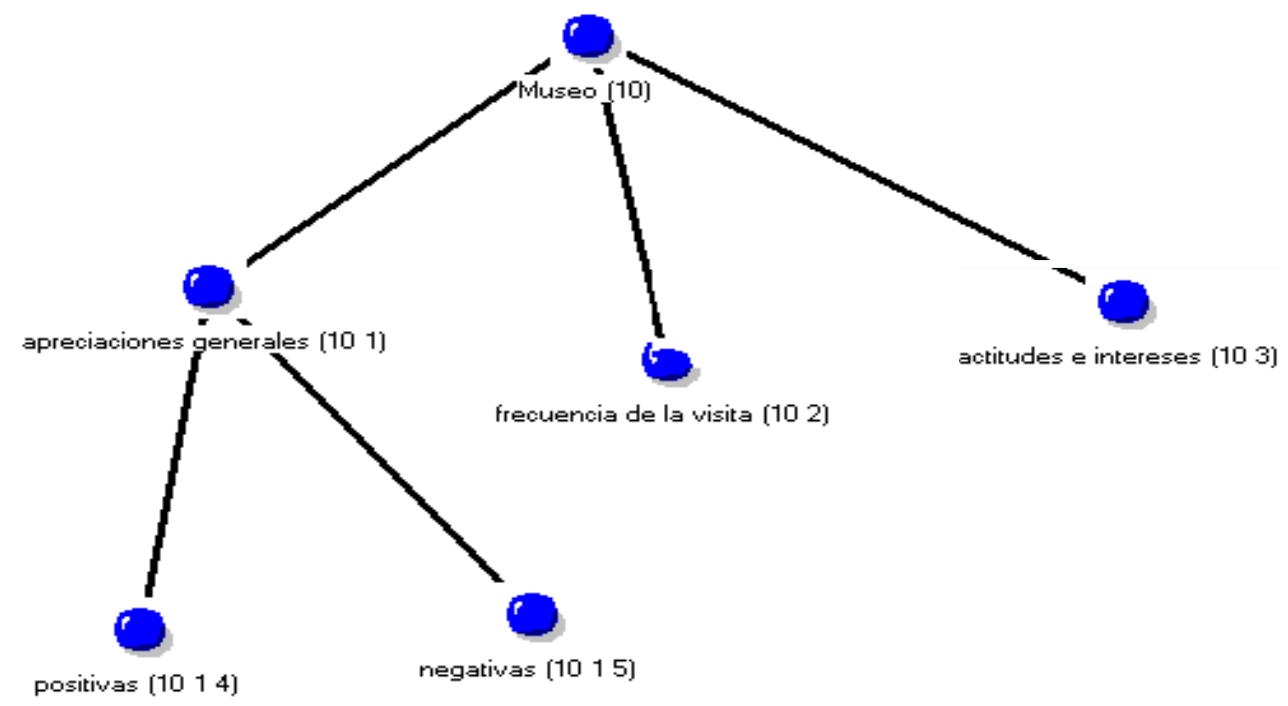


Se adjunta un cuadro con la síntesis numérica de la cantidad de definiciones contextuales incluidas en cada uno de ellos. Esta referencia no debe ser interpretada más que como una tendencia a su aparición espontánea en el discurso.

\begin{tabular}{|l|c|c|c|c|}
\cline { 2 - 5 } \multicolumn{1}{c|}{} & $\begin{array}{c}\text { Frecuencia } \\
\text { de la visita }\end{array}$ & $\begin{array}{c}\text { Actitudes e } \\
\text { intereses }\end{array}$ & $\begin{array}{c}\text { Apreciaciones } \\
\text { generales } \\
\text { positivas }\end{array}$ & $\begin{array}{c}\text { Apreciaciones } \\
\text { generales } \\
\text { negativas. }\end{array}$ \\
\hline $\begin{array}{l}\text { Cantidad de } \\
\text { DF }\end{array}$ & 36 & 52 & 34 & 19 \\
\hline
\end{tabular}

Específicamente en relación a la sala de exhibición, los conjuntos o nodos identificados guardan cierta correspondencia con los recursos expositivos, y fueron agrupados en tres niveles. Denominaremos de primer orden al nivel que toma como referencia algún elemento aislado de la sala, tales como los textos y los objetos de colección. También se incluye en este nivel las apreciaciones generales de la sala. Las categorías de segundo orden son aquellas que aluden a sectores específicos y, finalmente, las categorías de tercer orden admite todas las definiciones contextuales de mayor nivel de abstracción y que refieren a las temáticas tratadas en la sala de exhibición.

Una vez definidos los nodos según sean de primer orden, segundo y tercer orden, se identifican el conjunto de enunciaciones que refieren a dicho nodo y que, por diferencia, darán lugar, según las relaciones posibles, a las redes contrastantes o mundo semióticos posibles para un corpus dado en determinado momento y lugar.

La agrupación al interior de cada eje conceptual se construye a partir de lo efectivamente dicho a posteriori de la visita a la sala, enunciación que no preexiste a la experiencia del visitante. Cada categoría reciben una denominación de clase coherente en su condición tipológica.

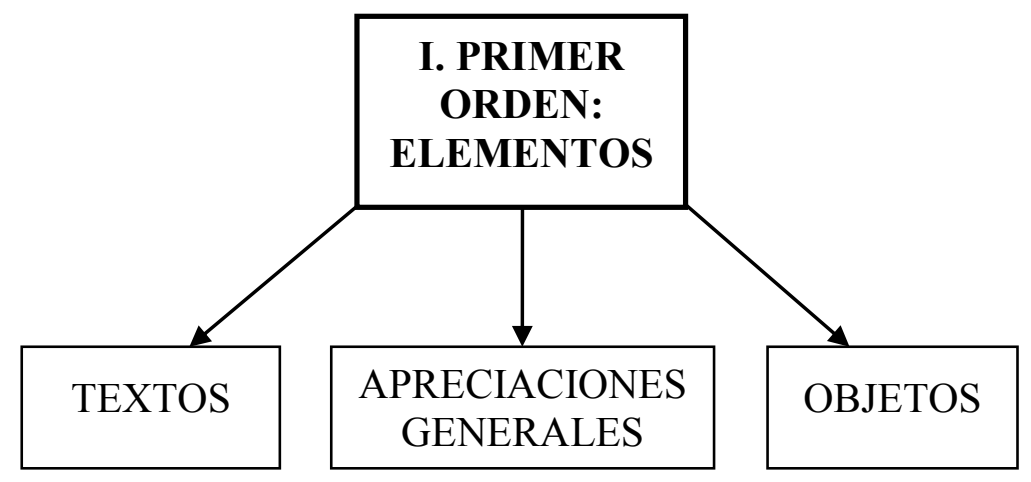


De segundo orden son aquellos nodos que toman como referencia a un conjunto de elementos que corresponden a instalaciones que, a su vez, son aludidos como sectores espaciales. Estos son: sector video, sector máscaras y sector escenario.

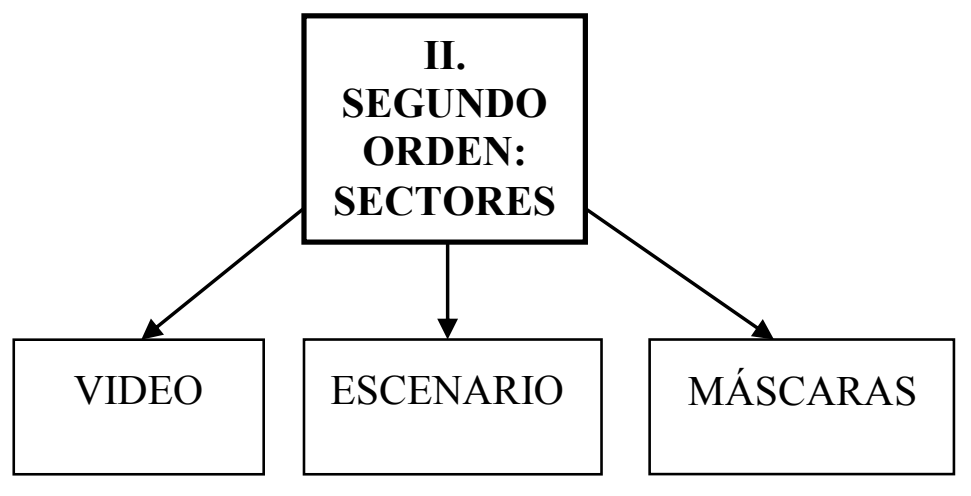

Por último, un tercer nivel está dado por la organización según unidades temáticas denominadas como alusión al tiempo, cultura/identidad y autoreferencialidad. Las definiciones contextuales que incluye el primer y segundo orden son identificables por el nivel de referencialidad con el que aparecen enunciadas. En relación a los nodos de tercer orden, los enunciados no siempre son explícitos y muchas veces su inclusión en el nodo se deduce del contenido total de la definición contextual.

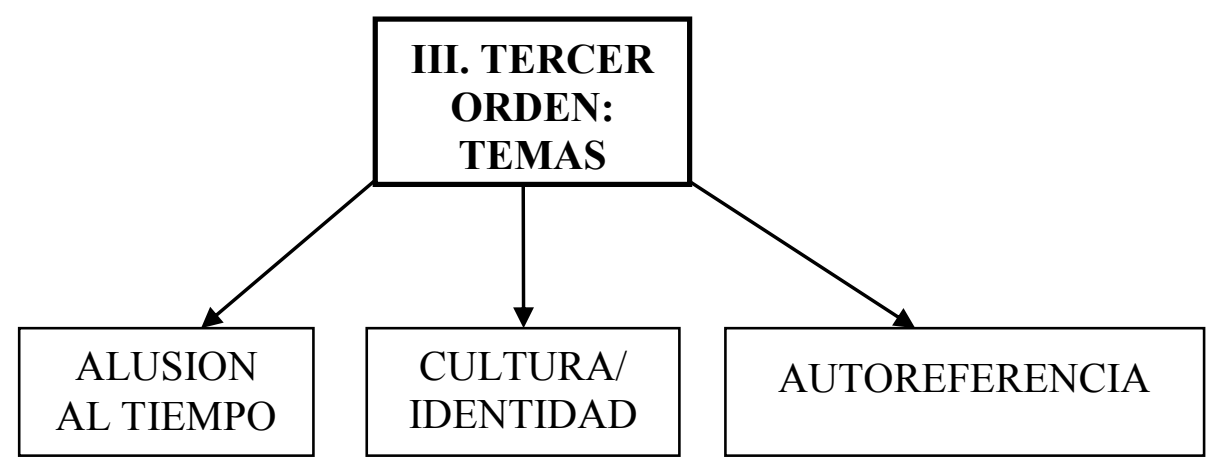

\section{VI.3. Análisis de las categorías de primer orden ${ }^{65}$}

\subsection{Apreciaciones generales sobre la sala}

En este apartado se incluyen todas las definiciones contextuales que refieren a la sala en sentido global. Estas hacen alusión al montaje y diseño, los distintos temas, actitudes y sentimientos. A su vez, las apreciaciones pueden agruparse en positivas y

${ }^{65}$ En el Anexo III se presentan ejemplos de definiciones contextuales para cada uno de los nodos y subnodos, en los tres órdenes. 
negativas. Dentro de las apreciaciones positivas se desprende un subnodo que agrupa aquellas relacionadas con aspectos actitudinales. Las referencias temáticas tales como lo nuestro, lo aborigen, la diversidad, las culturas autóctonas, entre otras serán recuperadas en el nodo de tercer orden cultura/identidad.

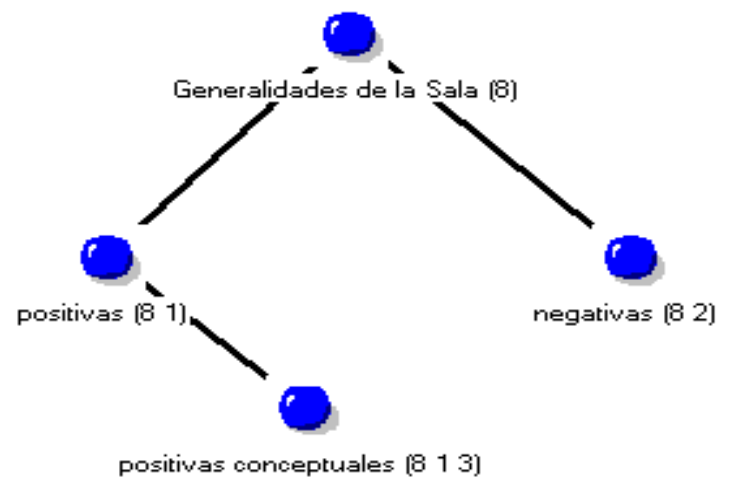

\begin{tabular}{|c|c|c|}
\hline $\begin{array}{c}\text { Apreciaciones generales } \\
\text { positivas }\end{array}$ & $\begin{array}{c}\text { Apreciaciones generales } \\
\text { negativas }\end{array}$ & $\begin{array}{c}\text { Apreciaciones positivas } \\
\text { conceptuales/ } \\
\text { actitudinales }\end{array}$ \\
\hline me gustó & textos largos & Aprender \\
\hline me encantó & difícil de entender & Conocer \\
\hline me impactó & faltan mujeres & Valorar \\
\hline bien iluminada & más fotos & Apreciar \\
\hline parece europea & más temas & Reflexionar \\
\hline -------------- & & Respetar \\
\hline
\end{tabular}

\begin{tabular}{|c|c|c|c|}
\cline { 2 - 4 } \multicolumn{1}{c|}{} & $\begin{array}{c}\text { Apreciaciones } \\
\text { positivas Generales }\end{array}$ & $\begin{array}{c}\text { Apreciaciones positivas } \\
\text { actitudinales }\end{array}$ & $\begin{array}{c}\text { Apreciaciones } \\
\text { negativas }\end{array}$ \\
\hline Cantidad de DF & 460 & 92 & 76 \\
\hline
\end{tabular}

\section{2. Los textos}

De las categorías de primer orden la más nombrada son los textos. La lectura de los mismos en una sala de exhibición demanda para el visitante una atención particular, lo intimida a interiorizarse y comprender el tema tratado, que requiere, en algún caso, de conocimientos previos. La experiencia de la lectura por parte del visitante es mucho más diferencial que otras experiencias perceptivas al alcance de todos. 
Si bien la adecuación de los textos resulta la "traducción/transformación" de los lenguajes técnicos/científicos al lenguaje de divulgación, la fidelidad disciplinar impone un límite a este proceso.

El análisis de las definiciones contextuales agrupadas en este apartado incluye las apreciaciones generales, tanto positivas como negativas; las referencias conceptuales y, por último las actitudinales.

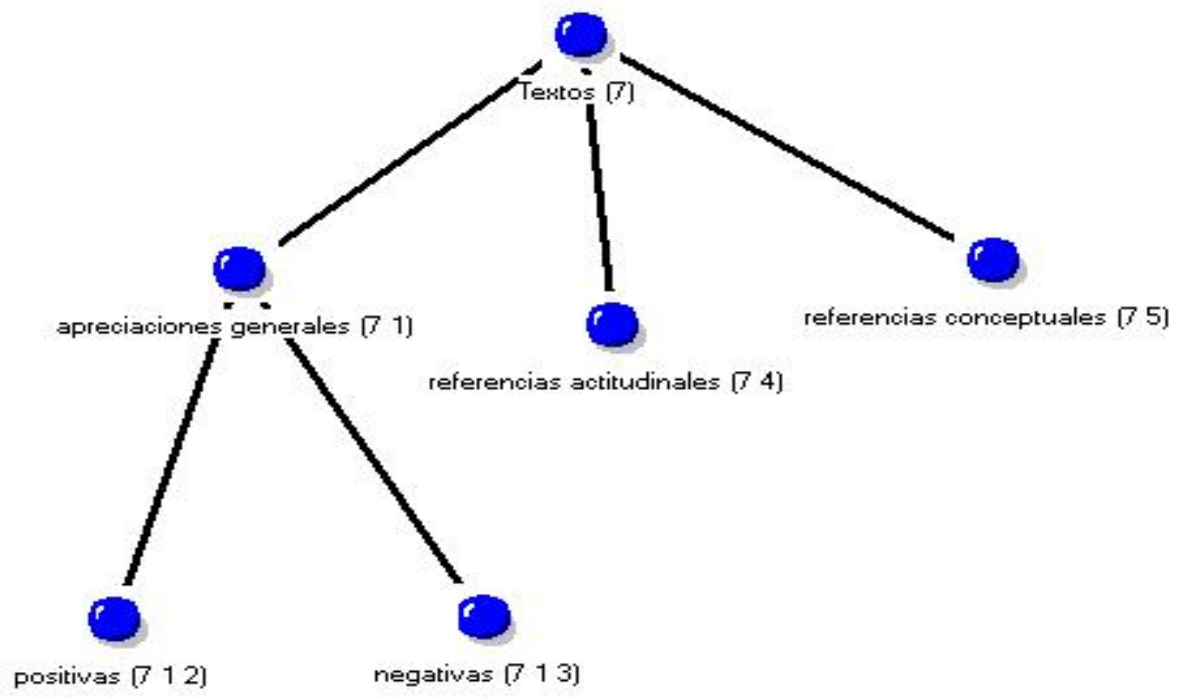

\begin{tabular}{|c|c|c|c|c|}
\cline { 2 - 5 } \multicolumn{1}{c|}{} & $\begin{array}{c}\text { Apreciaciones } \\
\text { generales } \\
\text { positivas }\end{array}$ & $\begin{array}{c}\text { Apreciaciones } \\
\text { generales negativas }\end{array}$ & $\begin{array}{c}\text { Referencias } \\
\text { actitudinales }\end{array}$ & $\begin{array}{c}\text { Referencias } \\
\text { conceptuales }\end{array}$ \\
\hline Cantidad de DF & 51 & 8 & 57 & 28 \\
\hline
\end{tabular}

\subsection{Objetos}

Dentro de esta categoría el análisis consiste en la evaluación de aquellos objetos que han sido nombrados espontáneamente con mayor frecuencia, para recuperar, a posteriori, las relaciones dadas en el discurso entre éstos y los otros nodos analizados.

Entre los objetos más nombrados se encuentran las canoas y las vestimentas. Se presentan en la enunciación con diversas denominaciones tales como embarcaciones, botes, barquitos en el primer caso y para el segundo caso ropas, textiles, indumentaria. Un segundo grupo de objetos está conformado por los instrumentos musicales y las máscaras. Por último también aparecen en el discurso los juegos, armas, collares y anclas. 


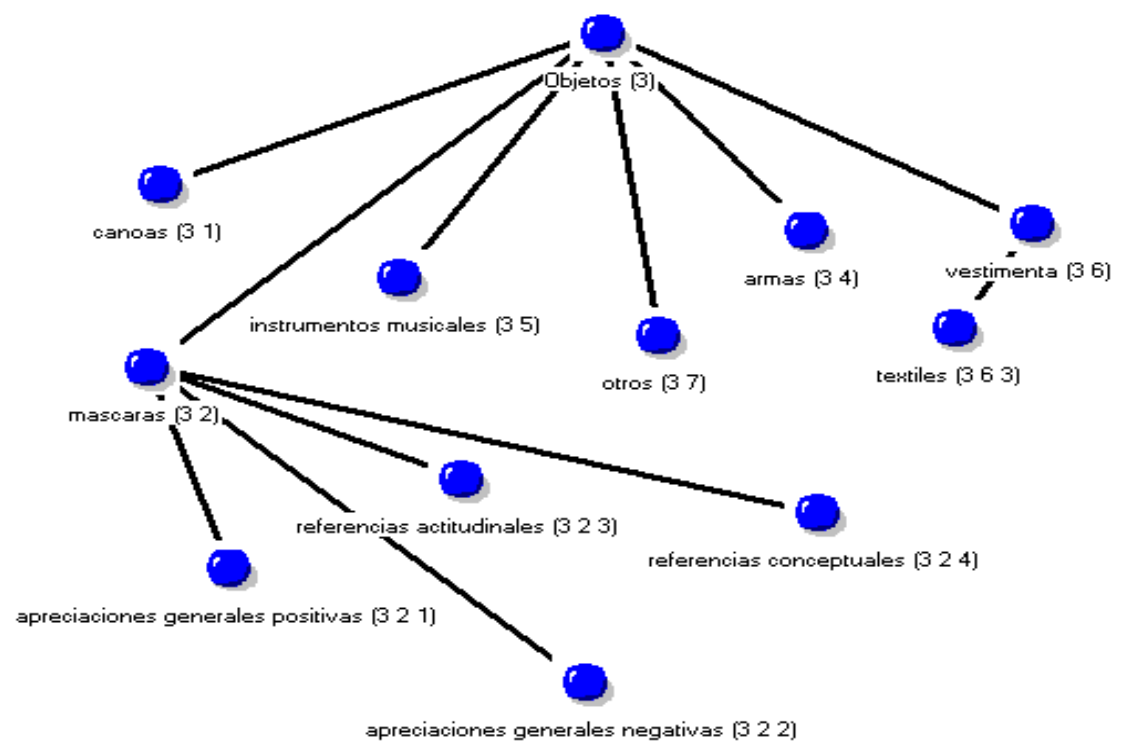

\begin{tabular}{|c|c|c|c|c|c|}
\cline { 2 - 6 } \multicolumn{1}{c|}{} & Canoas & Vestimenta & Máscaras & $\begin{array}{c}\text { Instrumentos } \\
\text { musicales }\end{array}$ & Armas \\
\hline $\begin{array}{c}\text { Cantidad de } \\
\text { D.C. }\end{array}$ & 50 & 40 & 17 & 11 & 10 \\
\hline
\end{tabular}

En general el contexto de enunciación tiene que ver con aquello que más gustó o llamó la atención pero es importante recalcar que con frecuencia los visitantes establecen relaciones con experiencias personales, lo que podrá recuperarse luego en el nodo designado como autoreferencia.

En algunos casos, la apreciación del valor del objeto se vincula a los sujetos productores, el trabajo y el ingenio o habilidad. También vinculado a su originalidad y autenticidad, generalmente asociado a los materiales y técnicas de confección.

Con respecto a las máscaras se desprenden un conjunto de subnodos que serán recuperados en las categorías de segundo orden ya que conforman un sector especial claramente delimitado en el espacio de la sala. Seguramente por estar ubicadas como parte de un contexto que incorpora una propuesta comparativa e interactiva con un componente lúdico, surge otra riqueza de asociaciones. Así, las definiciones contextuales se agrupan, como en otros nodos, en subnodos según apreciaciones positivas, negativas, actitudes y conceptos.

Finalmente, uno de los objetos también referenciados espontáneamente por el visitante es el Traje de los siete cueros del Cacique Chocorí, de procedencia tehuelche. 
Es el principal disparador de alusiones históricas y el objeto emblemático que delimita el ingreso a la sala e invita a su visita.

\section{VI.4. Análisis de las categorías de segundo orden}

\subsection{Sector máscaras}

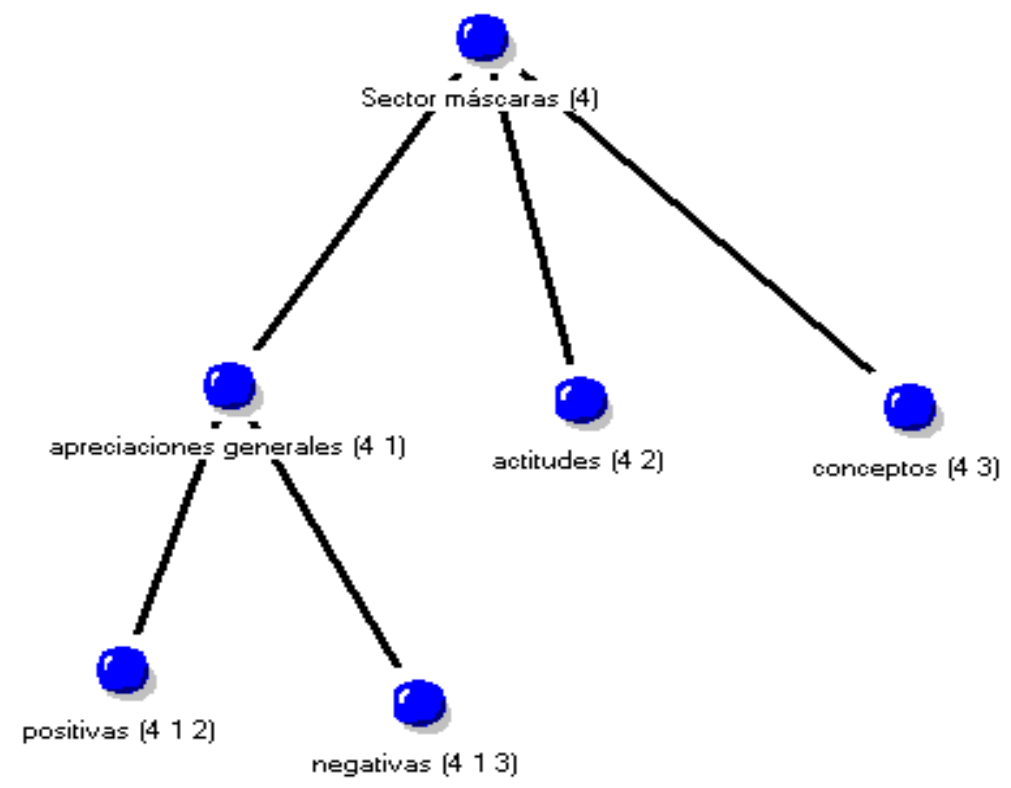

El sector de las máscaras es uno de los que surge con alto grado de asociación espontánea y del cual se ha incorporado la pregunta en caso de percibir una buena disposición por parte de los visitantes para prolongar la entrevista. Este sector se centra en la presentación de las máscaras de procedencia chané (Chaco salteño), contextualizado a dos niveles, el carnaval y la experiencia de enmascaramiento. Enfrentado espacialmente se encuentran cuatro máscaras de diversa procedencia y contextos de uso. A su vez incluye una propuesta interactiva que consiste en "asomarse enmascarándose" (Ver recursos expositivos en el capítulo IV). Este componente lúdico es uno de los mayores atractivos ya que el visitante ve reflejada su mirada en un espejo, incorporándolo visualmente en una escena del carnaval. Esta experiencia es muy apreciada para los chicos, resulta divertida, diferente a lo que se espera en una sala de museo y genera sentimientos de sorpresa, es por eso que la referencia de los visitantes alude a actitudes y sentimientos. Los nodos distinguidos se agrupan en apreciaciones generales positivas, apreciaciones generales negativas, actitudes y concepto. 
El cuadro que sigue presenta algunos ejemplos de esta organización. Es importante destacar la asociación a los rituales y la diversidad cultural, concepto que aparece con frecuencia.

\begin{tabular}{|c|c|c|c|}
\hline $\begin{array}{c}\text { Apreciaciones } \\
\text { generales } \\
\text { positivas }\end{array}$ & $\begin{array}{c}\text { Apreciaciones } \\
\text { generales } \\
\text { negativas }\end{array}$ & Actitudes & Concepto \\
\hline lindo & me me gustó & es un juego & $\begin{array}{c}\text { diversidad de } \\
\text { máscaras }\end{array}$ \\
\hline bueno & me impresionó & $\begin{array}{c}\text { verme en los ojos de } \\
\text { la otra máscara }\end{array}$ & $\begin{array}{c}\text { diversidad de } \\
\text { rituales }\end{array}$ \\
\hline interesante & me parecen feas & $\begin{array}{c}\text { miré que me estaban del } \\
\text { espiando }\end{array}$ & \\
\hline raro & & $\begin{array}{c}\text { es como que no se } \\
\text { sabe quien hay del } \\
\text { otro lado }\end{array}$ & \\
\hline excelente & & miré sin observar & \\
\hline divertido & & miré y me miré yo & \\
\hline & & me asombró & \\
\hline & & $\begin{array}{c}\text { me están mirando... } \\
\text { hasta que reaccioné } \\
\text { que era un espejo }\end{array}$ & \\
\hline & & \multicolumn{3}{|l}{} \\
\hline
\end{tabular}

\begin{tabular}{|c|c|c|c|c|}
\cline { 2 - 5 } \multicolumn{1}{c|}{} & $\begin{array}{c}\text { Apreciaciones } \\
\text { generales } \\
\text { positivas }\end{array}$ & $\begin{array}{c}\text { Apreciaciones } \\
\text { generales } \\
\text { negativas }\end{array}$ & $\begin{array}{c}\text { Comportamientos/ } \\
\text { Actitudes }\end{array}$ & conceptos \\
\hline Cantidad de D.C. & 35 & 8 & 18 & 31 \\
\hline
\end{tabular}

\subsection{Sector escenario}

El sector final de la sala, denominado escenario, está conformado por un conjunto de elementos que han sido seleccionados con la intención de que no tengan para el visitante una identificación tipológica con alguna cultura en particular. Los objetos exhibidos no pertenecen a las colecciones. Se trata de una instalación que recrea un espacio identificado como vivienda, que pretende movilizar ciertas reflexiones y ante el cual el visitante tiene, en relación al resto de la sala, mayor grado de libertad para su 
interpretación. En su interior puede leerse un fragmento del escritor Eduardo Galeano que alude a la identidad y los museos.

Del análisis de este nodo surgen las siguientes categorías que han sido agrupadas como:

- Aquellas que hacen referencia a la apreciación general, que, a su vez, pueden ser positivas o negativas.

- Las llamadas categorías referenciales, en dos niveles, los nombres que adjudican los visitantes al escenario como unidad (identidad de clase) y los objetos más nombrados (identidad de componentes).

- Estas categorías se relacionan, a su vez con las categorías conceptuales que dispara el escenario y sus formas discursivas.

- Finalmente es posible identificar categorías actitudinales que expresan sentimientos, actitudes experimentadas por el visitante. Estas pueden ser de inclusión o de exclusión respecto del "otro representado".

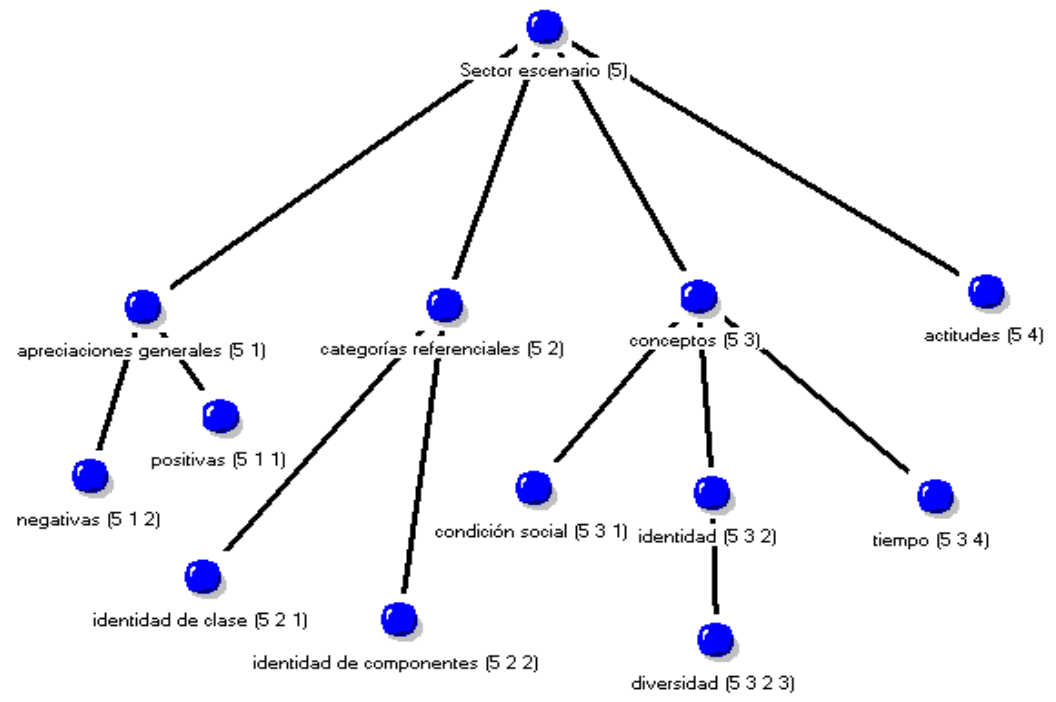

\begin{tabular}{|c|c|c|c|c|}
\cline { 2 - 5 } \multicolumn{1}{c|}{} & $\begin{array}{c}\text { Apreciaciones } \\
\text { positivas }\end{array}$ & $\begin{array}{c}\text { Apreciaciones } \\
\text { negativas }\end{array}$ & actitudes & concepto \\
\hline Cantidad de D.C. & 62 & 47 & 154 & 142 \\
\hline
\end{tabular}




\section{Apreciaciones generales}

\begin{tabular}{|c|c|}
\hline Positivas & Negativas \\
\hline me gustó & no entendí \\
\hline bárbaro & no lo vi \\
\hline bueno/buenísimo & lo pasé por alto \\
\hline excelente & no le di importancia \\
\hline lindo & no me gustó \\
\hline interesante & está de más \\
\hline real & \\
\hline divino & \\
\hline espectacular & \\
\hline
\end{tabular}

\section{Categorías referenciales}

\begin{tabular}{|c|c|}
\hline $\begin{array}{c}\text { Los nombres (identidad de } \\
\text { clase) } \\
\text { el escenario como un todo }\end{array}$ & $\begin{array}{c}\text { Los objetos (identidad de } \\
\text { componentes) }\end{array}$ \\
\hline piecita & el celular \\
\hline choza & la foto de Maradona \\
\hline rancho & el mate \\
\hline casa & el termo \\
\hline puestito & la pava \\
\hline & la radio \\
\hline & la frase de Galeano \\
\hline
\end{tabular}




\section{Categorías conceptuales}

Las categorías conceptuales pueden ser agrupadas según aludan al tiempo, a la condición social o a la identidad, del cual se desprende un subnodo referido a diversidad. Estos apartados tendrán su correlato en el análisis de los nodos de tercer orden.

\begin{tabular}{|c|c|c|c|}
\hline $\begin{array}{c}\text { Condición social } \\
\mathbf{9} \mathbf{~ d c}\end{array}$ & $\begin{array}{c}\text { Identidad } \\
\mathbf{7 6} \mathbf{~ d c}\end{array}$ & Diversidad & $\begin{array}{c}\text { Tiempo } \\
\mathbf{5 7} \mathbf{~ d c}\end{array}$ \\
\hline humilde & lo argentino & heterogéneo & Evolución \\
\hline pobre & nuestras costumbres & la mezcla de cosas & Cambio \\
\hline simple & nuestras raíces & contradicciones & Historia \\
\hline básico & cosas típicas & $\begin{array}{c}\text { cosas viejas y } \\
\text { nuevas }\end{array}$ & Presente \\
\hline singular & $\begin{array}{c}\text { un indígena o un } \\
\text { gaucho }\end{array}$ & $\begin{array}{c}\text { pérdida de } \\
\text { tradiciones }\end{array}$ & Lo nuevo \\
\hline & $\begin{array}{c}\text { lo poquito que uno } \\
\text { tiene }\end{array}$ & $\begin{array}{c}\text { la fusión de lo } \\
\text { diverso }\end{array}$ & el ahora \\
\hline & $\begin{array}{c}\text { como vive una } \\
\text { persona de afuera }\end{array}$ & $\begin{array}{c}\text { lo moderno con lo } \\
\text { antiguo }\end{array}$ \\
\hline
\end{tabular}

\section{Categorías actitudinales}

\begin{tabular}{|c|}
\hline El escenario de la sala ... \\
\hline me hace pensar (que es general) \\
\hline me sorprendió (el puestito) \\
\hline Interpreté (la mezcla de lo moderno y lo antiguo) \\
\hline me sorprendió (la mezcla de lo moderno y lo antiguo) \\
\hline me hizo pensar (en los cambios) \\
\hline me hace pensar (en el reflejo de las contradicciones nuestras) \\
\hline es como para quedarse \\
\hline me llamó la atención (no saber que querían hacer con eso) \\
\hline te hacer replantear (cómo vivimos nosotros) \\
\hline me llamó la atención \\
\hline no lo leí \\
\hline no me detuve a entenderlo \\
\hline
\end{tabular}




\begin{tabular}{|c|}
\hline mi impresión fue (de entrar a una casa muy pobre) \\
\hline me hizo pensar (que yo vivo bien y hay gente que no vive como yo) \\
\hline me hizo un ruido (porque no buscaba ver la camiseta de Maradona) \\
\hline me imagino que (es como vive una persona afuera) \\
\hline supongo que (debe ser donde está el sereno) \\
\hline supongo que (no pertenece a la sala, es de otra época) \\
\hline supongo que (debe ser de algún peón porque nada que ver con las cosas de la sala) \\
\hline invita a reflexionar (no es habitual esperarlo en un museo) \\
\hline te mueve un poquito \\
\hline me tuvo 5 minutos pensando \\
\hline nos reíamos (de lo que había) \\
\hline
\end{tabular}

Las reflexiones que promueve el escenario pueden ser agrupadas según sean de inclusión o exclusión, en relación a un nosotros/ otros/ellos. Estas serán recuperadas en el análisis de las categorías de tercer orden.

\subsection{Sector video y mapas}

Con respecto al video se agruparon 23 definiciones contextuales. No se han registrado apreciaciones negativas y las asociaciones generalmente están vinculadas a la presencia actual de tradiciones y prácticas ancestrales. También está valorado por el visitante como recurso por su atracción a los chicos. En este sector también se incluye la referencia a la temática del valor de la tierra y una propuesta comparativa de mapas de distribución de los grupos étnicos de Argentina en el siglo XVII y la actualidad. La alusión al tiempo y a la situación actual de los grupos representados se recupera en el análisis de las categorías de tercer orden.

\section{VI.5. Análisis de las categorías de tercer orden}

Las categorías de tercer orden son de carácter conceptual y se agrupan en tres nodos denominados como: tiempo, identidad y autorreferencialidad. Una vez aisladas y descriptas, el siguiente paso es el de establecer las relaciones con los nodos y subnodosde primer y segundo orden de manera de generar las matrices de datos. 


\subsection{Tiempo}

La alusión al tiempo está referenciada en el discurso de los visitantes a partir de distintos recursos expositivos. Conceptualmente se distinguen tres subnodos, aquel que toma como referencia el pasado, el que toma como referencia el presente y el que agrupa las definiciones contextuales donde el tiempo, a veces de forma implícita, está aludido como cambio o historia.

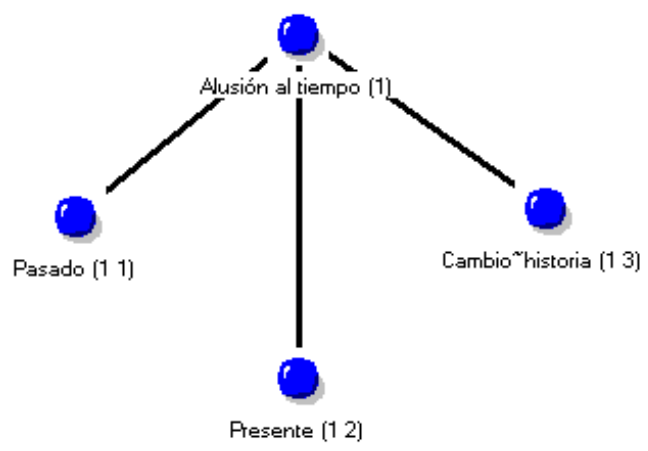

\begin{tabular}{|c|c|c|}
\hline Pasado & Presente & Cambio/historia \\
\hline lo anterior & el ahora & cosas nuevas \\
\hline el antes & lo cotidiano & lo que quedó \\
\hline otra época & la actualidad & el después \\
\hline lo precolombino & hoy & el comienzo y el fin \\
\hline lo arcaico & lo que quedó & lo de antes y lo de ahora \\
\hline lo antiguo & esta época & \\
\hline lo ancestral & lo moderno & \\
\hline
\end{tabular}

La relación de estas apreciaciones con los recursos expositivos se establece más claramente en el análisis relacional entre nodos, pero es posible anticipar que el pasado está aludido en la sala en general, en contraste con el cierre, escenario. El presente prevalece en el escenario, los mapas y el video. La visión histórica se asocia con mayor frecuencia al recorrido general, comienzo con el ayer y termina en el hoy. 


\section{2. Cultura/identidad}

Las enunciaciones agrupadas en el nodo denominado cultura/identidad atraviesan todos los sectores seleccionados para el análisis como referente de segundo orden. Estos son: máscaras, escenario y video.

En esta instancia el análisis deja transitoriamente de lado el sector disparador de lo enunciado, relación que será recuperada a posteriori en el cruce de las categorías.

Para su análisis hemos considerado la enunciación a partir de la presencia o no en el discurso de un "otro", a su vez calificado o clasificado como lo argentino, lo indígena, el aborigen, etc. y que se opone claramente a un "nosotros", organizada en dos categorías denominadas de exclusión e inclusión respectivamente. A su vez, es posible reconocer una tercera categoría que vincula ambos apartados y que da cuenta de la relación nosotros/otros (ellos).

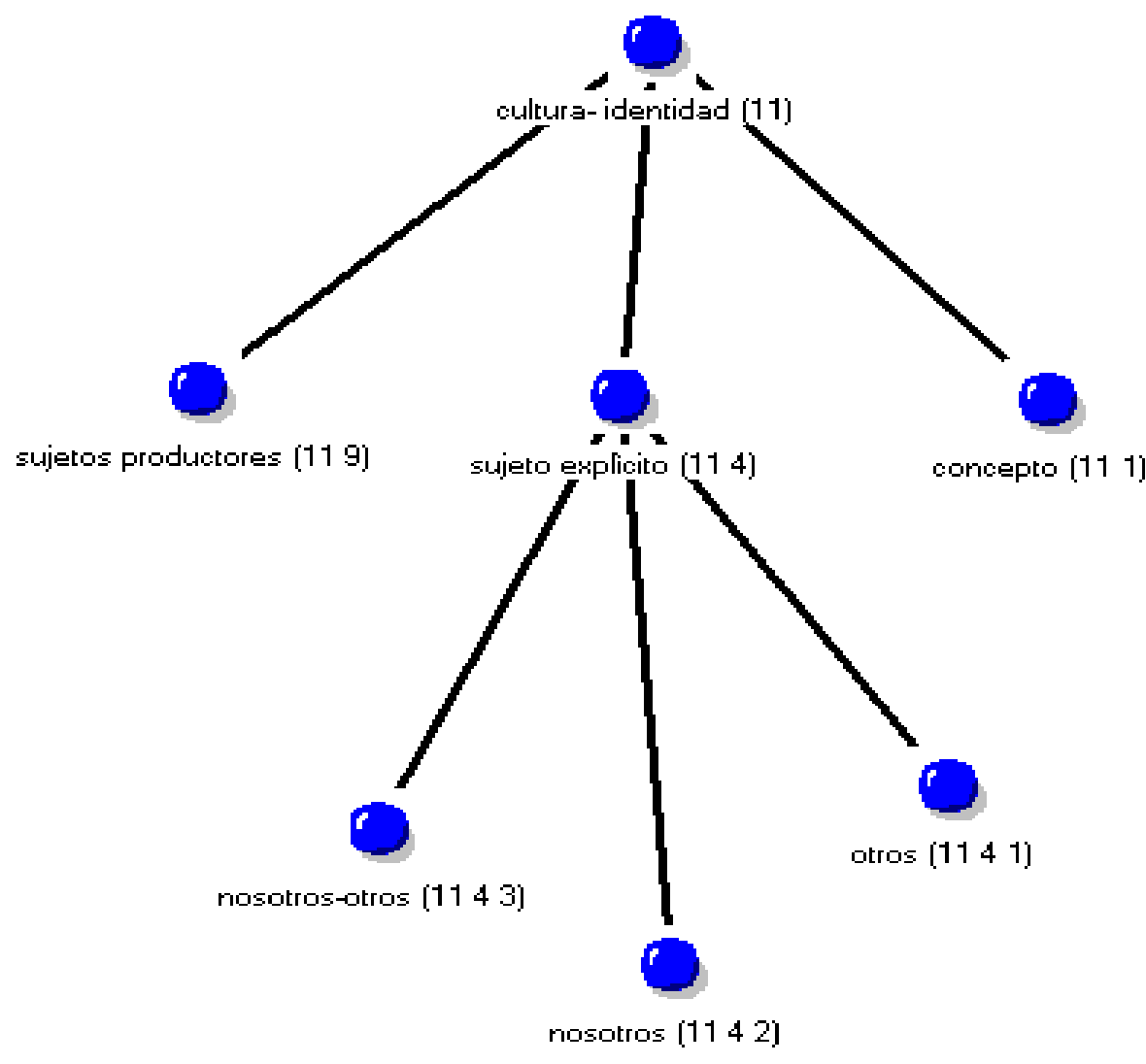

\begin{tabular}{|c|c|c|c|c|}
\cline { 2 - 5 } \multicolumn{1}{c|}{} & Nosotros & Otros & Nosotros-otros & Concepto \\
\hline $\begin{array}{c}\text { Cantidad de D.C. } \\
\text { Total de 357 }\end{array}$ & 60 & 83 & 72 & 125 \\
\hline
\end{tabular}


Será de inclusión aquella definición contextual en la que el visitante habla en primera persona plural o singular, por ej.: lo nuestro, los aborígenes, lo argentino.

Por el contrario, se considerará excluyente cuando el sujeto aludido se enuncia en tercera persona singular o plural. Una tercera categoría hace explicita la relación nosotros-otros (ellos).

El subnodo denominado concepto incluye una suerte de definición/descripción de la cultura. Las referencias son tanto espaciales, por ej.: las provincias; como atributos, por ej.: la mezcla o lo diverso.

\begin{tabular}{|c|c|c|}
\hline $\begin{array}{l}\text { Exclusión } \\
\text { (otros) }\end{array}$ & $\begin{array}{l}\text { Inclusión } \\
\text { (nosotros) }\end{array}$ & $\begin{array}{c}\text { Relación } \\
\text { (nosotros-otros) }\end{array}$ \\
\hline $\begin{array}{l}\text { tienen ahora cosas } \\
\text { antiguas }\end{array}$ & nuestros antepasados & $\begin{array}{l}\text { ver eso te hace replantear } \\
\text { como vivimos hoy }\end{array}$ \\
\hline $\begin{array}{c}\text { la vida cotidiana de los } \\
\text { aborígenes }\end{array}$ & & $\begin{array}{l}\text { el contacto con otras } \\
\text { culturas }\end{array}$ \\
\hline viven de esa manera & lo argentino & $\begin{array}{l}\text { tomamos elementos de las } \\
\text { culturas anteriores }\end{array}$ \\
\hline lo que usaba un aborigen & nuestra historia & $\begin{array}{l}\text { usamos elementos de las } \\
\text { culturas anteriores en lo } \\
\text { cotidiano }\end{array}$ \\
\hline $\begin{array}{l}\text { cómo vive la gente } \\
\text { humilde hoy }\end{array}$ & nuestras raíces & volvamos a las raíces \\
\hline $\begin{array}{c}\text { los que reclaman las } \\
\text { tierras }\end{array}$ & las cosas de todos & $\begin{array}{l}\text { uno viene viendo lo que } \\
\text { fue y termina viendo lo que } \\
\text { somos }\end{array}$ \\
\hline cosas de los nativos & $\begin{array}{c}\text { objetos que nos constituyen } \\
\text { como personas }\end{array}$ & $\begin{array}{l}\text { estamos así, con esa } \\
\text { mezcla de cosas }\end{array}$ \\
\hline $\begin{array}{c}\text { cosas con que trabajan } \\
\text { hoy }\end{array}$ & parte de la humanidad & $\begin{array}{c}\text { son más inteligentes ellos } \\
\text { que nosotros }\end{array}$ \\
\hline lo que tienen hoy & parte de lo que vivimos & $\begin{array}{l}\text { ellos cuidan más todo que } \\
\text { nosotros }\end{array}$ \\
\hline cómo fueron & lo nuestro & $\begin{array}{c}\text { en las grandes ciudades no } \\
\text { los respetamos }\end{array}$ \\
\hline lo otro & parte de lo que nos pasa & $\begin{array}{l}\text { todo autóctono para } \\
\text { conocernos }\end{array}$ \\
\hline la vivencia de esa gente & lo cercano a nosotros & somos todos descendientes \\
\hline
\end{tabular}




\begin{tabular}{|c|c|c|}
\hline & & de las distintas tribus \\
\hline esa época & nuestra identidad & $\begin{array}{l}\text { llegamos a jorobar a ellos } \\
\text { que estaban muy felices }\end{array}$ \\
\hline $\begin{array}{c}\text { como vive una persona } \\
\text { afuera }\end{array}$ & lo que nos identifica & \\
\hline $\begin{array}{l}\text { con lo poco que se } \\
\text { arreglaban }\end{array}$ & $\begin{array}{c}\text { cosas nuestras como el } \\
\text { mate }\end{array}$ & \\
\hline $\begin{array}{l}\text { los que viven así en } \\
\text { chaco, misiones... }\end{array}$ & & \\
\hline $\begin{array}{l}\text { los que viven con esa } \\
\text { mezcla }\end{array}$ & & \\
\hline lo que queda & & \\
\hline en el norte quedan más & & \\
\hline $\begin{array}{l}\text { lo que había antes de la } \\
\text { conquista }\end{array}$ & & \\
\hline $\begin{array}{l}\text { el indígena en la } \\
\text { actualidad }\end{array}$ & & \\
\hline $\begin{array}{l}\text { los que han ido } \\
\text { evolucionando a nivel } \\
\text { psíquico }\end{array}$ & & \\
\hline viven en la actualidad & & \\
\hline
\end{tabular}

\begin{tabular}{|c|}
\hline Concepto de Cultura/ identidad \\
\hline Diversidad \\
\hline Diferencia \\
\hline Mezcla \\
\hline Evolución \\
\hline Cambio \\
\hline Identidad \\
\hline Tecnología \\
\hline Convivencia \\
\hline
\end{tabular}




\subsection{Autorreferencia}

Incluye la totalidad de definiciones contextuales enunciadas en primera persona. Pueden reconocerse por lo menos tres elementos de autoreferencia: la procedencia del visitante, el conocimiento específico de algún tema y la asociación libre.

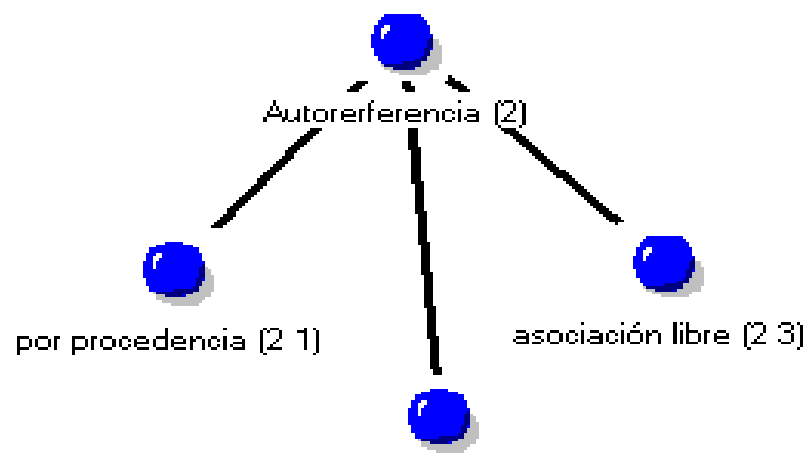

conocimiento [2 2]

\begin{tabular}{|c|c|c|c|}
\cline { 2 - 4 } \multicolumn{1}{c|}{} & Por procedencia & Por conocimiento & Por asociación libre \\
\hline Cantidad de D.C. & 18 & 70 & 44 \\
\hline
\end{tabular}

\section{VI.6. Resultados}

\section{Cuadro de síntesis}

\begin{tabular}{|c|c|c|}
\hline $\begin{array}{c}\text { Referentes de primer } \\
\text { orden }\end{array}$ & $\begin{array}{c}\text { Referentes de segundo } \\
\text { orden }\end{array}$ & $\begin{array}{c}\text { Referentes de tercer } \\
\text { orden }\end{array}$ \\
\hline Objetos & Sector video & Alusión al tiempo \\
\hline Textos & Sector final o escenario & Cultura /identidad \\
\hline Generalidades de la sala & Sector máscaras & Autoreferencia \\
\hline
\end{tabular}

Una vez identificados los apartados en los tres niveles de referencia, se cruzó la información estableciendo relaciones entre nodos de distinto orden, entre nodos y subnodos y con datos relevados en el perfil socio demográfico. El anexo III presenta las 
matrices de relaciones y sus valores.

A través de la interpretación de las matrices y sus resultados se configura una nueva instancia de interpretación en la cual se establecen correspondencias entre el contexto de apropiación y el contexto de re-presentación. Por otro lado, se discriminan, para algunos casos, tendencias según edad, nivel de instrucción, entre otros.

Por último, de este análisis resultará la evaluación de la eficacia comunicativa de la sala según las intenciones de los curadores y la visualización de los mundos semióticos posibles surgidos como consecuencia de la situación dada.

Las relaciones establecidas fueron las siguientes:

a) entre las categorías de tercer orden (tiempo, identidad y autoreferencia) con las categorías de primer orden (objetos, textos, generalidades),

b) entre las categorías de tercer orden (tiempo, identidad y autoreferencia) con las de segundo orden (sectores escenario, máscaras y video). Se incluyó la relación con los subnodos de tiempo (pasado, presente y cambio) con las categorías de segundo orden (sectores escenario, máscaras y video),

c) relaciones de nodos y subnodos con datos del perfil:

- entre los subnodos del apartado de identidad con datos del perfil tales como sexo, instrucción, procedencia y edad,

- entre el nodo de autoreferencia por sexo y edad,

- apreciaciones generales positivas y negativas del escenario por edad y por instrucción,

- entre el subnodo concepto del sector máscaras con nivel de instrucción.

El análisis relacional dio como resultados consideraciones y tendencias vinculadas a los aspectos generales, actitudinales y conceptuales por parte del visitante, referenciados en dos niveles, el de la forma y el contenido.

El contenido está asociado al logro de un aprendizaje y la comprensión de los temas e implican algún cambio por parte del visitante. En general éstos refieren al museo como un lugar donde aprender, conocer, valorar, reflexionar, respetar pero en las referencias concretas a sectores y/o objetos se asume el entretenimiento, la diversión, el pasatiempo. Así, el visitante se involucra en aquello que le llamó la atención como 
interés temático a lo que se le acopla la importancia de conocer: "la sala es aquella en la que uno puede ver aquello que uno ignora". Otro elemento que surgió como valor agregado de la sala en general tiene que ver con el hecho de tratar temas del presente.

En relación a los textos hay una diversidad de apreciaciones, desde concisos hasta muy extensos. Nuevamente forma y contenido se encuentran en una apreciación de diferente orden. No siempre aquellos que son largos son insuficientes en cuanto a la cantidad de información ofrecida, no es lineal la relación entre su extensión y su contenido. Si bien la lectura de los textos en relación a la visita es baja, en general la gente se justifica por la distracción por la presencia de chicos, falta de tiempo, etc. en muchos casos son apreciados: "si no hubiera textos no entendería nada".

Las actitudes respecto de los textos son divergentes, se leen solo aquellos vinculados a los temas de interés, y aquellos que jerarquizados gráficamente dan cuenta de la orientación general de la sala. Algo a destacar es el impacto producido por las palabras de E. Galeano, tanto por su forma poética como por la asociación al autor. Como referencias conceptuales se observa una cantidad significativa de alusiones a la comprensión del tema global tratado en la sala, la diversidad cultural.

En general se observa que la síntesis a la que llega el visitante no tiene necesariamente concordancia con la cantidad de tiempo que dedica al recorrido de la sala, podríamos afirmar que la temática general atraviesa toda la matriz conceptual de la sala con lo cual es posible desligarla de la mayor o menor intensidad con que se haya hecho el recorrido. Las apreciaciones acerca de los objetos están intensamente impregnadas por la valoración de su autenticidad. Esta no siempre esta expresada con este término pero se filtra en las consideraciones acerca de los materiales, las formas de confección, entre otras, y muchas veces se alude a los sujetos productores, sus habilidades y saberes: “me gustó la parte de cómo se fabrica el hilo con la planta”. Su interpretación simbólica aparece en menor grado dado que, en la mayoría de los casos se desprende de la lectura de los textos, pero no está ausente: "me impresiona todos los mensajes que dice que transmiten los textiles".

Objetos emblemáticos como el traje de los siete cueros del cacique Chocorí, propuesto como disparador de contenidos históricos, sin duda la confluencia de su ubicación espacial (ingreso), la presencia imponente, y la referencia a la pertenencia a 
un individuo del que se conoce su identidad, son elementos que fortalecen su valor patrimonial y autenticidad.

En relación a las categorías de segundo orden, los sectores, contienen una propuesta temática y constructiva más integral para la interpretación. Corresponden a la materialización de una temática más desprendida de la relación directa con el objeto. Ya hemos aludido a su relación con alguna forma de interacción o de planteo reflexivo El sector de las máscaras contempla los subnodos de apreciaciones generales negativas y positivas, actitudes y conceptos. Las apreciaciones generales incluyen sentimientos de diversión, sorpresa y curiosidad pero sin duda la máxima atracción está en su aspecto lúdico. En cuanto a los aspectos comportamentales la gente advierte el doble juego de ser visto y verse enmascarado: "no me daba cuenta que me estaban espiando", "verme en los ojos de la otra máscara fue interesante”, "verte del otro lado”. Conceptualmente surge la comparación y la diversidad a dos niveles, la diversidad morfológica del conjunto de máscaras y la diversidad entre culturas: "la parte de la máscara es aquella en la que ves la necesidad de distintos continentes que no se conocían y como todos tenían sus rituales".

El sector final o escenario podría ser calificado en el marco de la exhibición casi como una provocación, pues constituye una ruptura en el final del recorrido. Como ya fue comentado, se trata de una escena conformada por una serie de elementos cotidianos, el interior de una vivienda que no tiene, en el contexto de la sala, una adscripción cultural concreta. Esa quizás sea la primera sorpresa del visitante que espera encontrar en el museo cosas autenticas, típicas y antiguas. Esta instalación es una obra abierta a interpretaciones dispares e incluso contradictorias, donde el visitante ejerce el máximo grado de intervención, al punto de calificar el espacio como ajeno a la misma: "el lugar donde duerme el sereno"; o como disparador de recuerdos "se parece al taller de mi papá”. Un alto porcentaje de entrevistas contienen algún comentario sobre este sector. Conceptualmente el abanico de apreciaciones llegaron desde la incomprensión hasta la exaltación de la identidad como mezcla, lo que somos, lo que queda: "lo poquito que uno tiene". Aparece el mundo cotidiano con la fuerza del presente, el visitante deja atrás lo ajeno para incorporar lo argentino. Objetos emblemáticos como la foto de Maradona, un celular, una manta tejida en telar, el mate y la pava funcionan como disparadores del mundo conocido: "son todos símbolos". La mezcla y lo diverso está atravesado por el paso del tiempo y las asociaciones van desde 
la adjudicación de la escena a un presente así como en un sentido evolutivo, referenciando el progreso en el celular. También aparece el intercambio, "se ve bien reflejado como también tomamos algunos elementos de las culturas anteriores". Estas interpretaciones son producto de expresiones de inclusión y/o exclusión respecto de "otro" representado. Se encuentran bien diferenciados tres matices diferentes, la negación: "esto no debiera formar parte de una exhibición”, la distancia: "hay gente que vive asi", y finalmente de inclusión: "lo argentino, la mezcla que somos, nuestras contradicciones".

Por último, dentro de los apartados de segundo orden se incluye el sector del video editado especialmente para la sala y que pone "en contexto dinámico" la cultura cristalizada en las vitrinas. Este recorrido por las distintas regiones otorga presencia a los sujetos productores y actualidad a la cultura. Asimismo, la propuesta comparativa de los mapas es significativa en cuanto a la profundidad en el tiempo de la existencia de los pueblos originarios. La transcripción del artículo 75. Inciso 17 de la Constitución Nacional no deja dudas al respecto.

Finalmente, el análisis de las categorías de tercer orden de carácter conceptual atraviesa distintos recursos expositivos, relaciones que serán recuperadas en el cruce de variables. Según nuestros intereses y lo enunciado en la entrevista, los conceptos se agruparon en tres nodos: alusión al tiempo, identidad y autoreferencialidad.

El tiempo se organiza en pasado, presente, y cambio/historia. En general, cuando se trata del cambio se alude a una situación de pérdida, lo que quedó. Las colecciones, naturalmente asociadas al pasado no encuentran referente en el presente, parcialmente en el video. El pasado está referenciado en la generalidad de la sala, ligado a lo que fuimos, nuestras raíces y, si bien el recorrido general de la misma no es histórico, esto surge en la relación pasado/presente: "contrastar el país con las culturas antiguas, y con lo que están actualmente, realmente es impresionante”. Las condiciones actuales, el hoy, está concentrado en el escenario donde la presencia de los grupos adopta distintas connotaciones, como situación de pérdida de tradiciones, como mezcla de lo que somos como argentinos, como situación de pobreza y postergación. Aquí el nodo sobre el tiempo se vincula con el concepto de identidad, del que se han distinguido las siguientes categorías: cuando la referencia es impersonal y cuando es posible reconocer en la enunciación un sujeto explícito. 
La referencia impersonal alude a un concepto de identidad que está asociado a categorías tales como la diversidad, la diferencia, la mezcla, la evolución, el cambio, la tecnología, entre otros. Por otro lado, cuando el sujeto de la enunciación es explícito, los visitantes ejercen una práctica discursiva de inclusión, de exclusión y ajenidad y finalmente, relacional. En general este conjunto de oposiciones no forma parte del discurso de un mismo informante, el cual se posiciona claramente dentro, fuera o formando parte de esta construcción. Por otro lado, cada una de estas categorías es susceptible de juicios de valor, pero no necesariamente la exclusión está acompañada de prejuicio, sino, simplemente de no pertenencia. La ajenidad aparece como diferencia, como diversidad y su relación se establece con más fuerza cuando no se ha podido sacar a los grupos referenciados del pasado. A esto se contrapone la consideración de la identidad del nativo, el otro, atravesada por una apreciación según su condición social. Allí la diferencia asume el presente y la distancia con el otro se asocia a su marginalidad, pobreza, postergación. Es en este último punto donde la identidad se relaciona además de la diferencia, con la desigualdad. La instancia relacional del discurso está ligada a un proceso histórico: "ver como empezamos y como terminamos", o de inclusión directa: "está re bueno meter más de esas cosas de todos".

Finalmente, el nodo de autorreferencia contempla tres apartados: cuando la autorreferencia está ligada al conocimiento específico sobre el tema: "fui a ver la guitarra traída de Europa porque yo toco la guitarra"; "la sala es aquella que repensando el artículo 75 de la constitución, como abogado me hizo detener y pensar". Otras asociaciones autorreferenciales son de carácter libre: "el escenario es aquel que nosotros comparábamos con el galpón de mi papá”; "lo que más me llamó la atención fueron las chatitas peruanas porque decían Claudia, y yo me llamo Claudia”. Por último, la autorreferencialidad se liga a la procedencia del visitante: "por lo que me cuentan mis viejos a mí me vino enseguida a la mente el carnaval de Oruro"; "me encantan las canoas porque vivo a la orilla del río".

En relación al cruce de nodos se observa en general que la relación entre las mismas se mantiene, ya sea que se trate de la consideración de documentos, correspondiendo cada documento a uno y solo un informante y referencias, es decir el conjunto de enunciados referidos al nodo independientemente de su correspondencia con la cantidad de informantes. Esto nos da una pauta acerca de que la distribución temática en el total de las entrevistas está balanceada. Pero esto varía considerablemente 
cuando el tratamiento ingresa en el nivel de los subnodos. La lectura numérica no expresa en esta instancia la cantidad de definiciones contextuales que tratan el tema sino, el cruce conceptual de los temas, sectores y referentes. Es decir, establece la mayor tendencia en las asociaciones promovidas en la visita dentro de los nodos ya constituidos como categorías $\mathrm{y}$, recordemos, siempre surgidos de lo dicho por los visitantes.

Comparativamente, la alusión conceptual de las categorías de tercer orden (identidad, tiempo y autorreferencialidad) se encuentra más ligada a una apreciación general de la sala que a los textos y objetos (cuadros 1,2 y 3 ). Los valores aparecen más destacados para la alusión al tiempo y el concepto de identidad que la autorreferencialidad, instancia en la cual se equipara a los objetos.

La relación de la categoría de tercer orden con las de segundo orden destaca que la noción de tiempo surge fuertemente asociada al escenario, disminuyendo fuertemente en el video y está ausente en relación al sector de las máscaras (cuadro 4). Igual relación aparece asociada al sector final o escenario, si bien era de esperar que el video fuera un buen disparador de este concepto (cuadros 5). Para el apartado de la autoreferencia se mantiene esta relación pero para este caso los valores nulos corresponden al video (cuadro 6). Los subnodos que se desprenden del apartado alusión al tiempo -pasado, presente y cambio- conservan la fuerza referencial en el escenario, disminuyendo fuertemente en relación al pasado (cuadro 7).

Con el objeto de profundizar en el apartado sobre identidad, se establecieron relaciones entre las tres formas de construcción establecida a partir de una expresión de inclusión (nosotros), exclusión (otros/ellos) y la relación (nosotros/otros) con algunos datos del perfil de los visitantes. Aquí es necesario hacer una advertencia, pues para el análisis de las relaciones con el perfil sólo se tendrán en cuenta los documentos, de manera de conservar la correspondencia entre el dato del perfil y la cantidad de individuos.

Los valores más altos se encuentran en la variable excluyente, y asociada al sexo femenino (cuadro 8). Con respecto a los niveles de instrucción se observa muy poca variedad, en todos los niveles, entre las tres categorías, siendo los valores más elevados en los niveles de instrucción correspondiente a universitario incompleto, universitario completo y terciario completo (cuadro 9). Algo similar sucede con relación a la 
procedencia, siempre los valores más altos se encuentran relacionados con la exclusión (cuadro 10). Finalmente, la edad en la que el tema surgió con mayor frecuencia se concentra ente los 26 a 35 años y luego, la siguiente, entre 36 y 45 años (cuadro 11). Igualmente, para el nodo autorreferencia, se registra en las mismas franjas etáreas (cuadro 12). Para este mismo nodo la variación por sexo no resulta significativa (cuadro 13). Por último, con el objeto de evaluar el grado de aceptación del escenario final, fueron evaluadas las apreciaciones generales positivas y negativas acerca del escenario en la sala según edad y nivel de instrucción, pero esta relación no arrojó diferencias significativas.

En cuanto a la eficacia comunicativa de la sala de exhibición se ha podido comprobar una fuerte concordancia entre los objetivos planteados en la innovación de la misma, conceptualmente superadores de la situación anterior, y los discursos producidos por los visitantes como consecuencia de la visita. Apenas un diez por ciento de los entrevistados han agotado la interpretación de la sala de exhibición en las apreciaciones generales. La conjugación de los recursos y la acomodación de los objetos en los variados contextos propuestos y su equilibrio en el recorrido fueron motivo de diversas reflexiones por parte de los visitantes en torno a las ideas rectoras que guiaron la nueva "puesta en escena" de los materiales etnográficos. Este desplazamiento conceptual expresado como "de la tierra al territorio", "del pasado al presente", "del objeto al sujeto", "de lo ajeno a lo propio" encuentra anclaje en el contexto de representación y una apropiación diferencial por parte del visitante. A medida que los recursos generaron mayor participación y mayor ambigüedad de significado aumentó la forma de involucrarse por parte del visitante. Concebir la exhibición como un espacio discursivo complejo abre la comprensión a los procesos de aprendizaje diferencialmente experimentado por el visitante, haciendo de la visita una especial modalidad de apropiación del entorno donde cabe lo emocional, lo estético, lo lúdico, lo cognitivo. Por último, en su condición mediadora y adoptando, como hemos visto, el carácter de re-presentación, la sala de exhibición permitió recuperar una visión relacional y recreada de los "otros" representados donde la certeza de la información se enlaza con el espacio de proyección que el visitante necesita para involucrarse y convertir la visita en una experiencia de contemporaneidad. 


\section{Anexos}

1. Composición de la muestra.

2. Definiciones contextuales: ejemplos según apartados y nodos.

3. Matrices de relaciones entre nodos y subnodos. 


\section{Composición de la muestra}

Frecuencias (n) y porcentajes (\%) de los individuos analizados, según el sexo y el grupo etáreo.

\begin{tabular}{lrrrrrrr}
\hline Sexo & \multicolumn{2}{c}{ femenino } & \multicolumn{2}{c}{ Masculino } & \multicolumn{2}{c}{ Total } & \\
\hline Edad & $\mathrm{n}$ & $\%$ & $\mathrm{n}$ & $\%$ & $\mathrm{n}$ & $\%$ \\
\hline $16-25$ & 17 & 11.49 & 9 & 6.08 & 26 & 17.57 \\
$26-35$ & 26 & 17.57 & 23 & 15.54 & 49 & 33.11 \\
$36-45$ & 28 & 18.92 & 14 & 9.46 & 42 & 28.38 \\
$46-55$ & 11 & 7.43 & 5 & 3.38 & 16 & 10.81 \\
$56-65$ & 4 & 2.70 & 5 & 3.38 & 9 & 6.08 \\
$66-75$ & 2 & 1.35 & 3 & 2.03 & 5 & 3.38 \\
$76-85$ & 0 & 0.00 & 1 & 0.68 & 1 & 0.68 \\
Total & 88 & 59.46 & 60 & 40.54 & 148 & 100 \\
\hline
\end{tabular}

Frecuencias (n) y porcentajes (\%) de los individuos analizados, según el sexo y el nivel de instrucción.

\begin{tabular}{lrrrrrr}
\hline Sexo & \multicolumn{2}{c}{ femenino } & \multicolumn{2}{c}{ masculino } & \multicolumn{2}{c}{ Total } \\
\hline Instrucción & $\mathrm{n}$ & $\%$ & $\mathrm{~N}$ & $\%$ & $\mathrm{n}$ & $\%$ \\
\hline Primario completo & 6 & 4.05 & 4 & 2.70 & 10 & 6.76 \\
Secundario completo & 17 & 11.48 & 14 & 9.46 & 31 & 20.95 \\
Secundario incompleto & 6 & 4.05 & 3 & 2.03 & 9 & 6.08 \\
Terciario completo & 16 & 10.81 & 8 & 5.41 & 24 & 16.22 \\
Terciario incompleto & 7 & 4.73 & 1 & 0.67 & 8 & 5.40 \\
Universitario completo & 20 & 13.51 & 19 & 12.84 & 39 & 26.35 \\
Universitario incompleto & 16 & 10.81 & 11 & 7.43 & 27 & 18.24 \\
Total & 88 & 59.46 & 60 & 40.54 & 148 & 100 \\
\hline
\end{tabular}


Frecuencias (n) y porcentajes (\%) de los individuos analizados, según el sexo y la nacionalidad.

\begin{tabular}{lrrrrrr}
\hline Sexo & \multicolumn{2}{c}{ femenino } & \multicolumn{2}{c}{ masculino } & \multicolumn{2}{c}{ Total } \\
\hline Nacionalidad & $\mathrm{n}$ & $\%$ & $\mathrm{n}$ & $\%$ & $\mathrm{n}$ & $\%$ \\
\hline Argentina & 82 & 55.41 & 55 & 37.16 & 137 & 92.57 \\
Extranjera & 6 & 4.05 & 5 & 3.38 & 11 & 7.43 \\
Total & 88 & 59.46 & 60 & 40.54 & 148 & 100 \\
\hline
\end{tabular}

Frecuencias (n) y porcentajes (\%) de los individuos analizados, según el grupo etáreo y el máximo nivel de instrucción.

\begin{tabular}{|c|c|c|c|c|c|c|c|c|c|c|c|c|c|c|c|c|}
\hline \multirow{2}{*}{$\begin{array}{l}\text { Edad } \\
\text { Instrucción }\end{array}$} & \multicolumn{2}{|c|}{$16-25$} & \multicolumn{2}{|c|}{$26-35$} & \multicolumn{2}{|c|}{$36-45$} & \multicolumn{2}{|c|}{$46-55$} & \multicolumn{2}{|c|}{$56-65$} & \multicolumn{2}{|c|}{$66-75$} & \multicolumn{2}{|c|}{$76-85$} & \multicolumn{2}{|c|}{ Total } \\
\hline & $\mathrm{n}$ & $\%$ & $\mathrm{n}$ & $\%$ & $\mathrm{n}$ & $\%$ & $\mathrm{n}$ & $\%$ & $\mathrm{n}$ & $\%$ & $\mathrm{n}$ & $\%$ & $\mathrm{n}$ & $\%$ & $\mathrm{n}$ & $\%$ \\
\hline Primario completo & 0 & 0 & 3 & 2.03 & 2 & 1.35 & 3 & 2.03 & 2 & 1.35 & 0 & 0 & 0 & 0 & 10 & 6.76 \\
\hline Secundario completo & 2 & 1.35 & 15 & 10.14 & 6 & 4.05 & 4 & 2.71 & 2 & 1.35 & 1 & 0.68 & 1 & 0.68 & 31 & 20.95 \\
\hline Terciario completo & 2 & 1.35 & 6 & 4.05 & 12 & 8.11 & 1 & 0.68 & 2 & 1.35 & 1 & 0.67 & 0 & 0 & 24 & 16.22 \\
\hline Terciario incompleto & 3 & 2.03 & 3 & 2.03 & 2 & 1.35 & 0 & 0 & 0 & 0 & 0 & 0 & 0 & 0 & 8 & 5.41 \\
\hline Universitario completo & 2 & 1.35 & 10 & 6.76 & 16 & 10.81 & 7 & 4.7 & 2 & 1.35 & 2 & 1.35 & 0 & 0 & 39 & 26.35 \\
\hline Total & 26 & 17.57 & 49 & 33.11 & 42 & 28.38 & 16 & 10.81 & 9 & 6.08 & 5 & 3.38 & 1 & 0.68 & 148 & 100 \\
\hline
\end{tabular}


Frecuencias (n) y porcentajes (\%) de los individuos analizados, según la nacionalidad y el máximo nivel de instrucción.

\begin{tabular}{lrrrrrr}
\hline Nacionalidad & \multicolumn{2}{c}{ argentina } & \multicolumn{2}{c}{ extranjera } & \multicolumn{2}{c}{ Total } \\
\hline Instrucción & $\mathrm{n}$ & $\%$ & $\mathrm{n}$ & $\%$ & $\mathrm{n}$ & $\%$ \\
\hline Primario completo & 9 & 6.08 & 1 & 0.68 & 10 & 6.76 \\
Secundario completo & 28 & 18.92 & 3 & 2.03 & 31 & 20.95 \\
Secundario incompleto & 8 & 5.41 & 1 & 0.68 & 9 & 6.08 \\
Terciario completo & 23 & 15.54 & 1 & 0.68 & 24 & 16.22 \\
Terciario incompleto & 8 & 5.41 & 0 & 0 & 8 & 5.41 \\
Universitario completo & 35 & 23.65 & 4 & 2.70 & 39 & 26.35 \\
Universitario incompleto & 26 & 17.57 & 1 & 0.68 & 27 & 18.24 \\
Total & 137 & 92.57 & 11 & 7.43 & 148 & 100 \\
\hline
\end{tabular}

Frecuencias (n) y porcentajes (\%) de los individuos analizados, según el sexo y el tipo de ocupación.

\begin{tabular}{lrrrrrr}
\hline Sexo & \multicolumn{2}{c}{ femenino } & \multicolumn{2}{c}{ masculino } & \multicolumn{2}{c}{ Total } \\
\hline Ocupación & $\mathrm{n}$ & $\%$ & $\mathrm{n}$ & $\%$ & $\mathrm{n}$ & $\%$ \\
\hline ama de casa & 14 & 9.46 & 0 & 0 & 14 & 9.46 \\
comerciante & 4 & 2.70 & 5 & 3.38 & 9 & 6.08 \\
docente & 11 & 7.43 & 3 & 2.03 & 14 & 9.46 \\
empleado & 22 & 14.87 & 21 & 14.19 & 43 & 29.06 \\
estudiante & 18 & 12.16 & 12 & 8.11 & 30 & 20.27 \\
funcionaria & 1 & 0.68 & 0 & 0 & 1 & 0.68 \\
jubilado & 2 & 1.35 & 2 & 1.35 & 4 & 2.70 \\
profesional & 15 & 10.14 & 15 & 10.14 & 30 & 20.27 \\
otro & 1 & 0.68 & 2 & 1.35 & 3 & 2.03 \\
Total & 88 & 59.46 & 60 & 40.54 & 148 & 100 \\
\hline
\end{tabular}


Frecuencias (n) y porcentajes (\%) de los individuos analizados, según el sexo y el tipo de visita.

\begin{tabular}{lrrrrrr}
\hline Sexo & \multicolumn{2}{c}{ femenino } & \multicolumn{2}{c}{ masculino } & \multicolumn{2}{c}{ Total } \\
\hline Visita & $\mathrm{n}$ & $\%$ & $\mathrm{n}$ & $\%$ & $\mathrm{n}$ & $\%$ \\
\hline familia & 53 & 35.81 & 33 & 22.30 & 86 & 58.11 \\
grupo & 19 & 12.84 & 18 & 12.16 & 37 & 25.00 \\
pareja & 15 & 10.14 & 8 & 5.41 & 23 & 15.54 \\
sola & 1 & 0.68 & 1 & 0.68 & 2 & 1.35 \\
Total & 88 & 59.46 & 60 & 40.54 & 148 & 100 \\
\hline
\end{tabular}

Frecuencias (n) y porcentajes (\%) de los individuos analizados, según el máximo nivel de instrucción y el tipo de visita.

\begin{tabular}{lrrrrrrrrrr}
\hline Visita & \multicolumn{2}{c}{ familia } & \multicolumn{2}{c}{ grupo } & \multicolumn{2}{c}{ pareja } & \multicolumn{2}{c}{ sola } & \multicolumn{1}{c}{ Total } \\
\hline Instrucción & $\mathrm{n}$ & $\%$ & $\mathrm{n}$ & $\%$ & $\mathrm{n}$ & $\%$ & $\mathrm{n}$ & $\mathrm{n}$ & $\%$ \\
\hline Primario completo & 8 & 5.41 & 1 & 0.68 & 0 & 0.00 & 1 & 0.68 & 10 \\
Secundario completo & 22 & 14.87 & 5 & 3.38 & 4 & 2.70 & 0 & 0.00 & 31 & 20.95 \\
Secundario incompleto & 5 & 3.38 & 2 & 1.35 & 2 & 1.35 & 0 & 0.00 & 9 & 6.08 \\
Terciario completo & 16 & 10.81 & 4 & 2.70 & 4 & 2.70 & 0 & 0.00 & 24 & 16.22 \\
Terciario incompleto & 5 & 3.38 & 2 & 1.35 & 1 & 0.68 & 0 & 0.00 & 8 & 5.41 \\
Universitario completo & 23 & 15.54 & 9 & 6.08 & 6 & 4.05 & 1 & 0.68 & 39 & 26.35 \\
Universitario & & & & & & & & & \\
incompleto & 7 & 4.73 & 14 & 9.46 & 6 & 4.05 & 0 & 0.00 & 27 & 18.24 \\
Total & 86 & 58.11 & 37 & 25.00 & 23 & 15.54 & 2 & 1.35 & 148 \\
\hline
\end{tabular}


2. Definiciones contextuales: ejemplos según apartados y nodos.

NODO MUSEO

\begin{tabular}{|l|l|l|l|l|}
\hline & $\begin{array}{l}\text { Frecuencia de la } \\
\text { visita }\end{array}$ & $\begin{array}{l}\text { Actitudes e } \\
\text { intereses }\end{array}$ & $\begin{array}{l}\text { Apreciaciones } \\
\text { generales } \\
\text { positivas }\end{array}$ & $\begin{array}{l}\text { Apreciaciones } \\
\text { generales } \\
\text { negativas. }\end{array}$ \\
\hline Cantidad de DF & 36 & 52 & 34 & 19 \\
\hline
\end{tabular}

Apreciaciones generales positivas

Document 'N 12', 5 passages, 271 characters.

Section 0, Paragraph 2, 45 characters.

el museo es aquel que (+a mi) Me gustó mucho

Section 0, Paragraph 3, 60 characters.

(=el museo) es aquel que ( + a mi) (=me gustó) todo en general

Section 0, Paragraph 6, 53 characters.

(=el museo) es aquel al que $(+$ yo) veo muy interesante

Section 0, Paragraph 7, 53 characters.

(=el museo) es aquel al que (+yo) (=veo) muy remozado

Document 'N 125', 3 passages, 262 characters.

Section 0, Paragraph 10, 90 characters.

[el Museo] es aquel al que (+para mí) si van haciendo de a poco esto va a ser una maravilla

Document 'N 55', 1 passages, 83 characters.

Section 0, Paragraph 4, 83 characters.

(el museo=) es aquel que (+para nosotros) Toda la parte nueva está muy interesante

\section{Apreciaciones generales negativas}

Document 'N 106', 2 passages, 237 characters.

Section 0, Paragraph 9, 108 characters.

el museo es aquel que (+para mi) está viéndolo como un observador común [*con*] (los

contenidos mezclados $=$ )

Section 0, Paragraph 10, 129 characters.

el museo es aquel en el que (+para mi) caminas tres salas y todos los contenidos se te

mezclan porque no hay grupos de identidad

Document 'N 108', 2 passages, 239 characters.

Document 'N 17', 3 passages, 260 characters.

Section 0, Paragraph 15, 69 characters.

(=el museo) es aquel en el que (+para mi) (=hay cosas) Que se repiten

Section 0, Paragraph 18, 123 characters.

(=el museo) es aquel en el que (+para mi) hay ciertas salas que se hacen un poco cansadoras porque uno tiene que leer mucho

Section 0, Paragraph 19, 68 characters.

(=el museo) es aquel que (+yo) veces uno quiere que sea más dinámico

Section 0, Paragraph 7, 103 characters.

(=las sala más viejas) [del museo] son aquellas en las que (+para mi) (=no tenés tiempo) a interpretar

Section 0, Paragraph 8, 96 characters.

(= las salas viejas) son aquellas en las que (+para mi) (=no tenés tiempo) a que te cause cosas

Frecuencia de la visita

Document 'N 101', 1 passages, 66 characters.

Section 0, Paragraph 4, 66 characters.

[el museo] es aquel que Nosotros es la primera vez que estamos acá 
Document 'N 107', 1 passages, 65 characters.

Section 0, Paragraph 4, 65 characters.

(=el museo) es aquel que $(+$ yo) es la primera vez que vengo igual

Document 'N 12', 1 passages, 59 characters.

Section 0, Paragraph 5, 59 characters.

(=el museo) es aquel al que (+yo) hace tanto que no venía

Section 0, Paragraph 6, 77 characters.

[el Museo] es aquel al que (+yo) (=hace más de 25 años vine) Y era otro museo

Document 'N 127', 1 passages, 58 characters.

Section 0, Paragraph 5, 58 characters.

(=el Museo) es aquel al que yo es la primera vez que vengo

Document ' $\mathrm{N} 35$ ', 1 passages, 61 characters.

Section 0, Paragraph 6, 61 characters.

(Museo) es aquel al cual $(+$ yo) hacía mucho que siempre venía

Document 'N 46', 1 passages, 43 characters.

Section 0, Paragraph 7, 43 characters.

Museo es aquel al que yo nunca vine antes

Document 'N 76', 1 passages, 51 characters.

Section 0, Paragraph 28, 51 characters.

(=Museo) es aquel al que Yo vine hace como 30 años

\section{Actitudes/ intereses}

Document 'N 101', 1 passages, 52 characters.

Section 0, Paragraph 3, 52 characters.

[el museo]es aquel de la que a mi todo me interesa

Document 'N 108', 1 passages, 79 characters.

Section 0, Paragraph 6, 79 characters.

(=el museo) es aquel que (+para mi) Es realmente algo valioso que tengamos esto

Document 'N 125', 3 passages, 276 characters.

Section 0, Paragraph 2, 63 characters.

[el Museo]es aquel del que A mí me gustó más la parte de abajo

Section 0, Paragraph 3, 70 characters.

[el Museo]es aquel del que (+a mi)(=me gustó)más lo que es naturaleza

Document 'N 17', 3 passages, 241 characters.

Section 0, Paragraph 16, 80 characters.

(=el museo) es aquel en el que (+para mi) (=hay cosas) que yo siempre me acuerdo

Section 0, Paragraph 17, 75 characters.

(=el museo) es aquel en el que (+yo) a veces me doy cuenta lo que cambiaron

Document 'N 44', 5 passages, 574 characters.

Section 0, Paragraph 5, 81 characters.

(=el museo) es aquel en el que (+a mi) me interesa ver las (=culturas) nacionales

Section 0, Paragraph 6, 80 characters.

(=el museo) es aquel en el que (+a mi)me interesa ver las (=culturas) autóctonas

Section 0, Paragraph 7, 122 characters. 
(=el museo) es aquel en el que ( + A mi) (=me interesa) tratar de encontrar algún origen de cosas que uno hace cotidianamente

Section 0, Paragraph 53, 120 characters.

Museos son aquellos en el que $(+y o)$ una de las cosas que rescato es justamente eso [que muestren cosas de nuestro país]

Document 'N 46', 2 passages, 139 characters.

Section 0, Paragraph 8, 94 characters.

Museo es aquel que (+para mi) La colección que tienen [*en él *] es de verdad muy interesante

Document 'N 57', 1 passages, 111 characters.

Section 0, Paragraph 23, 111 characters.

(= museo) es aquel que Yo siempre cito cuando salen conversaciones de museos porque (+para mi) es impresionante

Document 'N 68', 2 passages, 166 characters.

Section 0, Paragraph 7, 73 characters.

(=el museo) es aquel en el cual (+nosotros) no nos detuvimos en detalles

Document 'N 7', 2 passages, 151 characters.

Section 0, Paragraph 3, 87 characters.

la parte de animales es aquella que (+nosotros) tiramos más para la parte de animales

\section{CATEGORIAS DE PRIMER ORDEN}

\section{I.1. APRECIACIONES GENERALES DE LA SALA}

\begin{tabular}{|l|l|l|l|}
\hline & $\begin{array}{l}\text { Apreciaciones } \\
\text { positivas } \\
\text { generales }\end{array}$ & $\begin{array}{l}\text { Apreciaciones positivas } \\
\text { actitudinales }\end{array}$ & $\begin{array}{l}\text { Apreciaciones } \\
\text { negativas }\end{array}$ \\
\hline Cantidad de DF & 460 & 92 & 76 \\
\hline
\end{tabular}

Ejemplos de apreciaciones positivas actitudinales

Document 'N 108', 2 passages, 316 characters.

Section 0, Paragraph 7, 104 characters.

(=la sala) es aquella de la que ( + a mi) Me pareció muy bien cómo están distribuidas las distintas zonas

Section 0, Paragraph 8, 212 characters.

(=la sala) es aquella que (+a mi) Me parece realmente muy interesante sobre todo pienso para los adolescentes [*que*] con un golpe de vista puede entender rápidamente algo sobre la vida de los pueblos aborígenes

Document 'N 109', 1 passages, 103 characters.

Section 0, Paragraph 4, 103 characters.

(=la sala) es aquella de la que ( + a mi) me encantó poder conocer de cerca todo lo que estábamos viendo

Document 'N 118', 2 passages, 156 characters.

Section 0, Paragraph 5, 98 characters.

(= la sala) es aquella de la que (=de la sala) (=me llamó más la atención) Todo lo que es creencia 
Document 'N 143', 1 passages, 187 characters.

Section 0, Paragraph 8, 187 characters.

(=la sala) es aquella en la que es (+para mi) (=los chicos) por más que tengan la computadora y todo eso igual no es lo mismo que traerlos y que lo ven acá donde pueden aprender distinto

Document 'N 148', 8 passages, 737 characters.

Section 0, Paragraph 5, 76 characters.

(=lo de acá) es aquello que (+para mi)si no lo conocés como lo vas a respetar

Section 0, Paragraph 6, 75 characters.

(=lo de acá) es aquello que (+para mi) (=si no conocés) como lo vas a cuidar

Document 'N 64', 1 passages, 120 characters.

Section 0, Paragraph 9, 120 characters.

(=la sala) es aquella de la cual (+a mi) me llamo la atención la reflexión a la referencia a la cuestión ética del final

Document 'N 72', 7 passages, 701 characters.

Section 0, Paragraph 3, 81 characters.

(=la sala) es aquella en la que (+para mi) $($ se ven=) Muchas cosas que uno ignora

\section{II.2.- LOS TEXTOS}

\begin{tabular}{|l|l|l|l|l|}
\hline & $\begin{array}{l}\text { Apreciaciones } \\
\text { generales } \\
\text { positivas }\end{array}$ & $\begin{array}{l}\text { Apreciaciones } \\
\text { generales negativas }\end{array}$ & $\begin{array}{l}\text { Referencias } \\
\text { actitudinales }\end{array}$ & $\begin{array}{l}\text { Referencias } \\
\text { conceptuales }\end{array}$ \\
\hline Cantidad de DF & 51 & 8 & 57 & 28 \\
\hline
\end{tabular}

\section{Apreciaciones generales positivas}

Document 'N 105', 1 passages, 69 characters.

Section 0, Paragraph 8, 69 characters.

(=los carteles) son aquellos que ( + a mi) me resultaron comprensibles

Document 'N 112', 1 passages, 76 characters.

Section 0, Paragraph 9, 76 characters.

(=los carteles de la sala) son aquellos que (+para mi) se entendía perfecto

Document 'N 114', 1 passages, 84 characters.

Section 0, Paragraph 13, 84 characters.

(=los textos de la sala) son aquellos que $(+$ yo) (=puede leer) porque [*son*]concisos

Document 'N 116', 1 passages, 64 characters.

Section 0, Paragraph 10,64 characters.

(= los carteles) son aquellos que (+para mi) [*son*] muy claros

Document 'N 126', 4 passages, 278 characters.

Section 0, Paragraph 12, 67 characters.

(=la sala) es aquella que (+para mi) explica muy bien realmente todo

Document 'N 146', 2 passages, 109 characters.

Section 0, Paragraph 10, 51 characters.

(=los textos) son aquellos que(+a mi) Me gustaron 
Document 'N 2', 1 passages, 78 characters.

Section 0, Paragraph 34, 63 characters.

(=los textos) son aquellos que (+para mi) Son muy interesantes

Document 'N 43', 1 passages, 65 characters.

Section 0, Paragraph 9, 65 characters.

(=los textos) son aquellos que (+a mi)(= me parecieron accesibles)

Document 'N 63', 2 passages, 197 characters.

Section 0, Paragraph 12, 118 characters.

(=la sala) es aquella en la que (+para mi) si no hubiera textos uno va pasando y va viendo y no sabe que es lo que ve

Document 'N 65', 2 passages, 154 characters.

Section 0, Paragraph 6, 75 characters.

(=las leyendas en las paredes) son aquellas que a mí me gusta en particular

Section 0, Paragraph 27, 90 characters.

(=las cosas que leímos) (=en la sala) son aquellas que (+para mi) [*son*] muy informativas

\section{Apreciaciones generales negativas}

Document 'N 111', 1 passages, 100 characters.

Section 0, Paragraph 5, 100 characters.

(=la sala) es aquella en la que (+ a mi) (=me gustaría) Que expliquen un poquito más en los carteles

Document 'N 126', 1 passages, 66 characters.

Section 0, Paragraph 10, 66 characters.

(=los carteles) son aquellos que (+para mi) A lo mejor son concisos

Document 'N 139', 1 passages, 98 characters.

Section 0, Paragraph 9, 98 characters.

(=los carteles) son aquellos que $(+$ yo) No pude leer lo de la yerba mate porque no me dan los lentes

Document 'N 3', 1 passages, 86 characters.

Section 0, Paragraph 35, 86 characters.

(=los textos) son aquellos de los cuales $(+$ yo) que no leía todos los textos muy largos

Section 0, Paragraph 17, 86 characters.

(= la sala) es aquella cuyos (=comentarios) (+ a mi) Me parece fabuloso pero difícil.

Document 'N 80', 1 passages, 74 characters.

Section 0, Paragraph 24, 74 characters.

(=los textos de la sala) son aquellos que (+para nosotros) Es un montonazo

\section{Referencias actitudinales}

Document 'N 107', 2 passages, 142 characters.

Section 0, Paragraph 8, 73 characters.

(=los carteles) son aquellos de los que (+yo) (=leí) Lo que me interesaba

Document 'N 112', 1 passages, 78 characters.

Section 0, Paragraph 8, 78 characters.

(=los carteles de la sala) son aquellos que (+yo) Algunas cosas si pude leer

Document 'N 113', 1 passages, 71 characters.

Section 0, Paragraph 14, 71 characters. 
(=los textos) (=de la sala) son aquellos que (+nosotros) No leímos mucho

Document 'N 116', 1 passages, 57 characters.

Section 0, Paragraph 9, 57 characters.

(= los carteles) son aquellos que $(+y o)$ pude leer un poco

Document 'N 128', 1 passages, 69 characters.

Section 0, Paragraph 10, 69 characters.

(=los carteles) son aquellos a los que $(+$ yo) Le saqué un par de fotos

Document 'N 129', 1 passages, 82 characters.

Section 0, Paragraph 12, 82 characters.

(=la sala) es aquella de la que (+nosotros) Estuvimos leyendo todo (=los carteles)

Document 'N 136', 1 passages, 101 characters.

Section 0, Paragraph 21, 101 characters.

(=el escenario) es aquel del que (+a mi) me llamó la atención lo que dice allí (=la frase de

Galeano)

Document 'N 142', 1 passages, 77 characters.

Section 0, Paragraph 9, 77 characters.

(=los textos) son aquellos que (+yo) no leí casi nada Por eso quiero más fotos

Document 'N 15', 1 passages, 78 characters.

Section 0, Paragraph 10, 78 characters.

(los textos) de (=la sala) son aquellos que (+yo) los tendría que haber leído

Document 'N 3', 6 passages, 458 characters.

Section 0, Paragraph 37, 87 characters.

(=los textos) son aquellos que (+para mi) está bueno cuando están más como resaltados

Document 'N 46', 1 passages, 69 characters.

Section 0, Paragraph 14, 69 characters.

(=los textos) son aquellos que (+nosotros) no nos detuvimos (=a leer)

Document 'N 54', 1 passages, 53 characters.

Section 0, Paragraph 7, 53 characters.

(= los textos) son aquellos que (+yo) (=leí) algunos

Document 'N 63', 3 passages, 286 characters.

Section 0, Paragraph 8, 128 characters.

(=los textos de la sala) son aquellos en los que (+nosotros) nos tomamos el tiempo de leer para interpretar que estamos viendo

Referencias conceptuales

Document 'N 110', 3 passages, 305 characters.

Section 0, Paragraph 12, 81 characters.

(=los textos) (= de la sala) son aquellos que (+para mi) el primero explica todo

Document 'N 135', 2 passages, 458 characters.

Section 0, Paragraph 33, 324 characters.

(=los textos) son aquellos de los que (+a mi) Estos comentarios [que aluden a la identidad] me parecen formidables [*porque*] yo dicto en una especialización en Filosofía

Contemporánea, un módulo llamado "Multiculturalismo", y esto (=de los carteles) se parece mucho a lo que dice un filósofo canadiense llamado Charles Tylor

Section 0, Paragraph 34, 134 characters. 
(=los textos) son aquellos que (+a mi) me parece muy bueno porque es una reflexión que recoge la totalidad de lo que uno alcanza a ver

Document 'N 150', 1 passages, 108 characters.

Section 0, Paragraph 10, 108 characters.

(=la sala) es aquella de la que $(+\mathbf{a} \mathbf{m i})(=$ me gustaron) los carteles que te cuentan de la vida de los aborígen

Document 'N 36', 3 passages, 260 characters.

Section 0, Paragraph 6, 75 characters.

(=la sala) es aquella cuyos (=comentarios) (+para mi) son bastante profundos

Section 0, Paragraph 7, 77 characters.

(=la sala) es aquella cuyos (=comentarios) (+para mi) (=son) sobre diversidad

Section 0, Paragraph 26, 108 characters.

Aborígenes son aquellos de los que $(+$ yo $)(=v i)(=$ en la sala) la reforma de $1995(=$ sobre el reclamo de tierras)

Document 'N 43', 2 passages, 159 characters.

Section 0, Paragraph 5, 74 characters.

(=la sala) es aquella en la cual (+yo) Estaba leyendo la historia del mate

Document 'N 65', 4 passages, 486 characters.

Section 0, Paragraph 5, 162 characters.

las leyendas en las paredes son aquellas que a mí me gustaron varias de (+para mi) (=las leyendas en las paredes) es como que hacen reflexionar un montón de cosas

Section 0, Paragraph 6, 75 characters.

(=las leyendas en las paredes) son aquellas que a mí me gusta en particular

Section 0, Paragraph 10, 178 characters.

(=la leyenda de etnografía) son aquellas que (+a mi) me gustó realmente porque siempre pensé que se refería más a lo anterior y es como también que tiene una mirada de sociólogo

Document 'N 67', 2 passages, 190 characters.

Section 0, Paragraph 14, 95 characters.

(= la sala) es aquella de la que (+para mi) Uno lee lo que más le impacta, Galeano por ejemplo

\subsection{LOS OBJETOS}

\begin{tabular}{|l|l|l|l|l|l|}
\hline & canoas & vestimenta & máscaras & $\begin{array}{l}\text { Instrumentos } \\
\text { musicales }\end{array}$ & armas \\
\hline $\begin{array}{l}\text { Cantidad de } \\
\text { D.C. }\end{array}$ & 50 & 40 & 17 & 11 & 10 \\
\hline
\end{tabular}

Document 'N 122', 2 passages, 219 characters.

Section 0, Paragraph 6, 82 characters.

(=la sala) es aquella de la que (+para mi) (=es interesante) el tema de las canoas

Section 0, Paragraph 9, 137 characters.

(=las canoas) son aquellas de las que (+para mi) las herramientas lo precarias que serían en esa época y sin embargo qué bien las hacían

Document 'N 96', 1 passages, 104 characters.

Section 0, Paragraph 6, 104 characters. 
las canoas (=de la sala) son aquellas que ( + a mi) (=me gustaron) porque son de distintas partes del mundo.

Document 'N 51', 5 passages, 492 characters.

Section 0, Paragraph 12, 83 characters.

la ropa es aquella que (+para mi) está bueno la forma cómo la hacían (=los

indios)

Section 0, Paragraph 19, 124 characters.

La campera (=de la sala) es aquella que (+a mi) (=me llamó la atención) porque [*es*]

finita, de cuero, con pelito adentro

Section 0, Paragraph 23, 101 characters.

(La campera) (=de la sala) es aquella que (+a mi) (=me llamó la atención) porque estaba como pintada

Document 'N 141', 2 passages, 191 characters.

Section 0, Paragraph 8, 102 characters.

(=la sala) es aquella de la que (+a mi) (=me gustó) (=la parte) de cómo se fabrica el hilo con plantas

Document 'N 37', 5 passages, 571 characters.

Section 0, Paragraph 5, 122 characters.

(= la sala) es aquella de la cual ( + a mi) Me impresionaron los colores y los diseños de las

texturas de los textiles

Section 0, Paragraph 7, 117 characters

(=la sala) es aquella de la cual (+a mi)(=me impresionaron) todos los mensajes que dice que $\operatorname{trasmiten}(=\operatorname{los}$ textiles$)$

Document 'N 2', 8 passages, 788 characters.

Section 0, Paragraph 23, 75 characters.

(=La sala) es aquella en la cual (+ a mi) Me gustó mucho lo de los gauchos

Section 0, Paragraph 25, 164 characters.

porque uno por ejemplo en historia estudiamos la guerra contra el indio pero (=en

historia no=)estudiamos la guerra no... de esto (la parte indígena=) no se ve nada

Document ' $\mathrm{N}$ 4', 3 passages, 150 characters.

Section 0, Paragraph 38, 53 characters.

(=el maniquí) es aquel que (+para mi) está buenísimo

Document 'N 6', 1 passages, 73 characters.

Section 0, Paragraph 7, 73 characters.

el maniquí del chocorí de la sala\} es aquello que (+para mi) es un indio

Document 'N 60', 1 passages, 85 characters.

Section 0, Paragraph 3, 85 characters.

(=la sala) es aquella que (+para mi) de movida tiene un sello fuerte con la armadura

\section{CATEGORIAS DE SEGUNDO ORDEN}

\section{II.1. SECTOR MASCARAS}

\begin{tabular}{|l|l|l|l|l|}
\hline & $\begin{array}{l}\text { Apreciaciones } \\
\text { generales positivas }\end{array}$ & $\begin{array}{l}\text { Apreciaciones } \\
\text { generales negativas }\end{array}$ & actitudes & conceptos \\
\hline Cantidad de D.C. & 35 & 8 & 18 & 31 \\
\hline
\end{tabular}

Apreciaciones negativas

Document 'N 130', 1 passages, 110 characters.

Section 0, Paragraph 10, 110 characters. 
(=la sala) es aquella de la que (+yo) No entendí mucho que tenía que ver con el resto (=la máscara de samurái)

Document 'N 16', 4 passages, 340 characters.

Section 0, Paragraph 7, 76 characters.

(=el sector) de las máscaras es aquel (=de la sala) que (+a mi) No me gustó

Section 0, Paragraph 9, 103 characters.

(=la sala) es aquella en la que (+para mi) todo lo demás [menos el sector de las máscaras] está bárbaro

Section 0, Paragraph 10, 74 characters.

(=las máscaras) (=de la sala) son aquellas que (+para mi) parecen muy feas

\section{Apreciaciones positivas}

Document 'N 46', 1 passages, 71 characters.

Section 0, Paragraph 16, 71 characters.

El [sector] de las máscaras es aquel que (+para mi) (está muy lindo=)

Document 'N 50', 1 passages, 65 characters.

Section 0, Paragraph 5, 65 characters.

(=la sala) es aquella de la que (+a mi)) (=me gustó) las máscaras

Document 'N 59', 2 passages, 157 characters.

Section 0, Paragraph 4, 79 characters.

(=la sala) es aquella de la que (+a mi) (=me llamaron la atención) Las máscara

Section 0, Paragraph 5, 78 characters.

(=de la sala) la sala es aquella cuyas (=máscaras) (+para mi) están muy buenas

Document 'N 6', 1 passages, 67 characters.

Section 0, Paragraph 15, 67 characters.

(= el sector de las máscaras)es aquel que (+para mi) está muy bueno

Document 'N 76', 1 passages, 104 characters.

Section 0, Paragraph 9, 104 characters.

La parte de las máscaras es aquella en la que $(+\mathbf{a} \mathbf{m i})(=l o$ que estuve leyendo)(=me parece) muy interesante

Document 'N 9', 1 passages, 61 characters.

Section 0, Paragraph 4, 61 characters. Actitudes

La parte de las máscaras es aquella que (+para mí) está loco

Document 'N 109', 1 passages, 117 characters.

Section 0, Paragraph 5, 117 characters.

(=la sala) es aquella de la que (+a mi) (=me gustó más) (=la parte) de las máscaras porque está para que uno juegue

Document 'N 11', 2 passages, 190 characters.

Section 0, Paragraph 8, 79 characters.

(=lo de las caras) [las máscaras] es aquello que (+a mi) me dio mucha impresión 
Document 'N 124', 2 passages, 219 characters.

Section 0, Paragraph 4, 118 characters.

(=la sala) es aquella de la que (+a nosotros) (= lo que más nos gustó fue) La pared que tiene para verte del otro lado

Document 'N 14', 1 passages, 116 characters.

Section 0, Paragraph 5, 116 characters.

(las máscaras=) son aquellos nenitos que están en el fondo con los ojitos para mirar y (+ él)

[el hijo] se divirtió

Document 'N 20', 1 passages, 80 characters.

Section 0, Paragraph 16, 80 characters.

el sector de las máscaras] es aquella parte donde se ponían los ojos y se veía.

Document 'N 3', 4 passages, 508 characters.

Section 0, Paragraph 14, 117 characters.

(=El juego de las máscaras) es aquel en el que (+ para mi )Verme en los ojos de la otra máscara (=estuvo interesante)

Section 0, Paragraph 16, 124 characters.

(=El juego de las máscaras) es aquel en el que (+a mi) (=verme en los ojos de la otra máscara) Primero me hizo como asustar

Section 0, Paragraph 17, 141 characters.

(=El juego de las máscaras) es aquel en el que ( + a mi (=verme en los ojos de la otra máscara me asustó) porque vi a otra persona del otro lado

Document 'N 34', 1 passages, 93 characters.

Section 0, Paragraph 13, 93 characters.

(=la sala) es aquella en la que a ellos (=los chicos) los divirtió mucho lo de las máscaras

Document ' $\mathrm{N}$ 5', 3 passages, 349 characters.

Section 0, Paragraph 25, 88 characters.

(= el sector de las máscaras) (=de la sala) es aquel del que (+yo) No sabía que miraban

Section 0, Paragraph 27, 137 characters.

(= el sector de las máscaras) (=de la sala) es aquel en el que (+yo) (=no me daba cuenta que era) hasta que miré que me estaban espiando

Document 'N 51', 2 passages, 216 characters.

Section 0, Paragraph 6, 109 characters.

(= la sala) es aquella de la que (+a mi) me asombró que vos mirás [*por*] una máscara

[*y*] metés los ojos

Section 0, Paragraph 7, 107 characters.

(=la máscara) es aquella que (+para mi) [*cuando*] (=mirás) es como que no se sabe quién hay del otro lado

Document 'N 54', 3 passages, 258 characters.

Section 0, Paragraph 9, 89 characters.

(=la sala) es aquella de la cual a mí (= me sorprende la máscara) porque primero miré mal Section 0, Paragraph 10, 101 characters.

(=la sala) es aquella de la cual a mí (= me sorprende la máscara) (= porque) (+yo) miré sin observar

\section{Conceptos}

Document 'N 109', 1 passages, 138 characters.

Section 0, Paragraph 6, 138 characters.

(=la sala) es aquella de la que (+a mi) (=me gustó más) (=la parte) de las máscaras

(=porque está para que uno) conozca los significados 
Document 'N 118', 1 passages, 91 characters.

Section 0, Paragraph 6, 91 characters.

(= la sala) es aquella de la que (+a mi) (=me llamó más la atención) lo que es las máscaras

Document 'N 135', 5 passages, 702 characters.

Section 0, Paragraph 10, 221 characters.

esas máscaras son aquellas que (+para mí) como son tan particulares porque no son máscaras de carnaval occidental por lo menos sino máscaras de rituales aborígenes desconocidos por lo menos para mí me parecen formidables

Section 0, Paragraph 13, 72 characters.

Las máscaras de acá son aquellas que $(+a$ mi) me parecen muy ornamentales

Section 0, Paragraph 14, 99 characters.

(=las máscaras de acá)son aquellas en las que (+para mi) hay una elaboración estética más compleja

Section 0, Paragraph 15, 196 characters.

(=las máscaras de acá) son aquellas en las que (+para mi) se nota que es el trabajo artesanal primario que realiza el aborigen y que con los rasgos que les da es suficiente para su valor simbólico

Section 0, Paragraph 16, 114 characters.

(=las máscaras de acá)son aquellas en las que (+para mi) la simbolización está metida en otra red de significados

Document 'N 44', 1 passages, 119 characters.

Section 0, Paragraph 16, 119 characters.

(=la sala) es aquella en la que (+para mi) esta bueno un poco el tema de mezclas con el tema de las máscaras ahí atrás

Document 'N 53', 2 passages, 345 characters.

Section 0, Paragraph 15, 176 characters.

la parte de máscaras (=de la sala) es aquella en la que (=para mi) [ves] la necesidad de distintos continentes que no se conocían entre sí [**] como todos tenían sus rituales

Document 'N 54', 1 passages, 199 characters.

Section 0, Paragraph 22, 199 characters.

(=la sala) es aquella de la cual (+Yo)(= entendí como era la cultura del hombre) Porque al haber a un lado distintas máscaras o cosas de samurai y todo eso [se ven] distintos comportamientos humanos

Document 'N 80', 2 passages, 197 characters.

Section 0, Paragraph 20, 89 characters.

las máscaras (=de la sala) son aquella de las cuales (+nosotros) (=leímos) Muchas cosas

Section 0, Paragraph 21, 108 characters.

(=las máscaras) (=de la sala) son aquellas de las cuales (+nosotros) (=leímos) las explicaciones que tenían

\section{II.2. SECTOR ESCENARIO}

\begin{tabular}{|l|l|l|l|l|}
\hline & $\begin{array}{l}\text { Apreciaciones } \\
\text { Positivas }\end{array}$ & $\begin{array}{l}\text { Apreciaciones } \\
\text { negativas }\end{array}$ & actitudes & concepto \\
\hline Cntidad de D.C. & 62 & 47 & 154 & 142 \\
\hline
\end{tabular}

Apreciacines generales positivas

Document 'N 100', 7 passages, 499 characters.

Section 0, Paragraph 5, 59 characters.

[el escenario] es aquel que ( + a nosotros) nos impactó mucho

Section 0, Paragraph 15, 54 characters.

[el escenario] es aquel que (+para mi) Está muy bueno 
Section 0, Paragraph 19, 87 characters.

[el escenario] es aquel que yo creo que tiene mucho que ver (=con el resto de la sala)

Section 0, Paragraph 21, 70 characters.

[el escenario] es aquel que (+para mi) no podría no estar (=en la sala)

Document 'N 110', 1 passages, 65 characters.

Section 0, Paragraph 5, 65 characters.

[el escenario] es aquel que (+para mi) el final así es muy bueno

Document 'N 5', 3 passages, 312 characters.

Section 0, Paragraph 15, 104 characters.

el póster de Maradona es aquel que (+para mi) es un detalle muy, muy bueno [del

escenario] (=de la sala)

Document 'N 61', 3 passages, 187 characters.

Section 0, Paragraph 5, 57 characters.

[el escenario] es aquel que ( + a mi) (=me pareció) divino

Section 0, Paragraph 6, 60 characters.

[el escenario] es aquel que (+a mi) me pareció espectacular

Document 'N 69', 1 passages, 77 characters.

Section 0, Paragraph 2, 77 characters.

(=el escenario de la sala) es aquel en el cual (+a mi) me gustó lo que decía

Document 'N 76', 1 passages, 68 characters.

Section 0, Paragraph 27, 68 characters.

(=el escenario final) es aquel que (+a mi) (=me parece) Interesante

Document 'N 83', 2 passages, 208 characters.

Section 0, Paragraph 8, 108 characters.

[el escenario] (=de la sala) es aquel del cual (+a mi) (=me llamó la atención) la frase del libro de Galeano

Document 'N 85', 2 passages, 193 characters.

Section 0, Paragraph 8, 115 characters.

[escenario] es aquel que no sabemos qué es que[*fue*](=lo que más nos llamó la atención)

$(+$ Nosotros) $(=$ de la sala $)$

Document 'N 93', 1 passages, 70 characters.

Section 0, Paragraph 16, 70 characters.

(el escenario final) es aquel que (+para mi) (=está) muy bien pensado

Apreciaciones generales negativas

Document 'N 101', 2 passages, 159 characters.

Section 0, Paragraph 8, 75 characters.

(=el escenario) (=de la sala) es aquel que (+a mi) (=me pareció) como raro

Document 'N 107', 2 passages, 113 characters.

Section 0, Paragraph 9, 55 characters.

(=el escenario) es aquel que $(+$ yo) no lo entendí mucho

Document 'N 109', 1 passages, 73 characters.

Section 0, Paragraph 7, 73 characters.

(=la sala) es aquella de la que (+yo) no entendí bien eso (=el escenario)

Document 'N 113', 5 passages, 511 characters.

Section 0, Paragraph 9, 125 characters.

(=el escenario) es aquel del que (+a mi) (=me llamó la atención el celular) [*porque*] [me parece] un poco fuera de contexto 
Document 'N 44', 1 passages, 95 characters.

Section 0, Paragraph 21, 95 characters.

(=el escenario) es aquel en el que (+yo) vi la camiseta de Maradona y me desconecté de la sala

\section{Categorías conceptuales}

Document 'N 100', 3 passages, 271 characters.

Section 0, Paragraph 6, 114 characters.

[=el escenario] (=de la sala) es aquel que (+a nosotros) (=nos impactó) cómo están ahora viviendo [los aborígenes]

Section 0, Paragraph 12, 51 characters.

[el escenario] es aquel que lo ves acá en la villa

Document 'N 101', 2 passages, 305 characters.

Section 0, Paragraph 14, 202 characters.

(=el escenario) (=de la sala) es aquel que Me imagino yo que está como mezclado lo propio del aborigen con la civilización que se les va encima y entonces tienen un celular, La foto de Diego, la Spica

Document 'N 106', 1 passages, 97 characters.

Section 0, Paragraph 14, 97 characters.

(=el escenario) es aquel en el que (+yo) Supongo que quisieron expresar una mezcla de identidades

Document 'N 107', 1 passages, 65 characters.

Section 0, Paragraph 18, 65 characters.

(=el escenario) es aquel en el que (+para mi) son todos símbolos

Document 'N 111', 2 passages, 653 characters.

Section 0, Paragraph 20, 267 characters.

(=el escenario)es aquel del que Yo la lectura que hice fue, bueno, nosotros los argentinos, exagerados que somos los mejores, los más grandes, los más... y al final, mirá el cacho de madera... culturalmente parece...pobrecitos yo les re menosprecié a los aborígenes de acá

Document 'N 113', 1 passages, 122 characters.

Section 0, Paragraph 12, 122 characters.

(=el escenario) es aquel en el que (+yo) Supongo que (=hay un celular) [*como*] algo como común denominador de la sociedad

Document 'N 134', 2 passages, 167 characters.

Section 0, Paragraph 9, 84 characters.

(=el escenario) es aquel en el que (+para mi) dentro de poco ponen la computadora

Document 'N 142', 2 passages, 144 characters.

Section 0, Paragraph 12, 70 characters.

(=el escenario) es aquel en el que (+para mi)Como que se ve el cambio

Section 0, Paragraph 13, 74 characters.

(=el escenario) es aquel en el que (+para mi)(=como que se ve) el progreso

Document 'N 145', 2 passages, 229 characters.

Section 0, Paragraph 11, 116 characters.

(=el escenario) es aquel que (+a mi) Me gusta porque muestra cosas de distintos orígenes pero que están todas juntas

Document 'N 148', 2 passages, 142 characters.

Section 0, Paragraph 13, 69 characters.

(=el escenario) es aquel que (+para mi) resume una forma de lo nuestro

Document 'N 16', 4 passages, 525 characters. 
Section 0, Paragraph 15, 72 characters.

las cosas [del escenario] son aquellas que (+para mi) Son todas típicas

Section 0, Paragraph 18, 148 characters.

[el escenario] (=de la sala) es aquel en el que (+para mi) se ve bien reflejado como también tomamos algunos elementos de las culturas anteriores

\section{Categorías actitudinales}

Document 'N 3', 2 passages, 193 characters.

Section 0, Paragraph 19, 83 characters.

(=la sala) es aquella que (+ a mi) [*me pareció*] realmente interesante el remate

Section 0, Paragraph 25, 110 characters.

(=la frase de Galeano) es aquella que (+a mi) (=me hace pensar en) El reflejo de las

contradicciones nuestras

Document 'N 35', 2 passages, 204 characters.

Section 0, Paragraph 14, 83 characters.

(=el escenario final) (=de la sala) es aquel que (+para mi [*es*] como para quedarse

Document 'N 36', 3 passages, 393 characters.

Section 0, Paragraph 15, 123 characters.

(= el escenario final)(=de la sala) es aquel cuyos comentarios sobre la diversidad (+para mi)

hay que leerlos y pensarlos

Document 'N 37', 3 passages, 269 characters.

Section 0, Paragraph 17, 108 characters.

(=el escenario)(=de la sala) es aquel del cual (+a mi) me llamó la atención La foto de

Maradona en ese lugar

Document 'N 4', 3 passages, 398 characters.

Section 0, Paragraph 30, 132 characters.

(= el escenario final) es aquel que (+para mi) mi impresión (=fue el de entrar a una casa) (= muy pobre) Con... apenas las reliquias

Section 0, Paragraph 31, 124 characters.

(= el escenario final) es aquel que (+para mi) mi impresión (=fue el de entrar a una casa) (= muy pobre con) Lo que uno ama

Section 0, Paragraph 32, 142 characters.

(=el escenario final) es aquel que (+para mi) mi impresión (=fue el de entrar a una casa) (= muy pobre Con) Lo poquito que tiene estaba ahí.

Document 'N 42', 1 passages, 47 characters.

Section 0, Paragraph 10, 47 characters.

(=el escenario) es aquel que (+para mi) Es real

Document 'N 43', 3 passages, 198 characters.

Section 0, Paragraph 10, 60 characters.

(=el escenario final) es aquel que ( $+\mathbf{a} \mathbf{m i})(=$ me hizo pensar)

Document 'N 44', 4 passages, 338 characters.

Section 0, Paragraph 24, 46 characters.

(+ a mi) (= el escenario) $(=$ me hizo) Un ruido

Section 0, Paragraph 25, 125 characters.

(=el escenario) es aquel que (+a mi) $\left[{ }^{*} q u e^{*}\right](=$ me hizo)(=un ruido) porque no buscaba

(=ver) justamente la camiseta de Maradona

Document 'N 52', 1 passages, 91 characters.

Section 0, Paragraph 10, 91 characters.

(=el escenario) es aquel que (+para mi) [*es*] Como que se está perdiendo las tradiciones

\section{II.3. SECTOR VIDEO}


Document 'N 123', 1 passages, 111 characters.

Section 0, Paragraph 10, 111 characters.

(=la sala) es aquella que (+para mi) Vos le mostrás (=a los chicos) y ellos están que quieren ver el televisor

Document 'N 37', 3 passages, 410 characters.

Section 0, Paragraph 29, 144 characters.

(= la película)(=de la sala)es aquella en la que (=vi) ese tipo de cosas que (+para mi) veo que durante siglos o décadas se ha mantenido igual

Document 'N 41', 4 passages, 377 characters.

Section 0, Paragraph 7, 58 characters.

(=el video) es aquel que (+para mi) también está muy bueno

Section 0, Paragraph 8, 149 characters.

(=el video) es aquel en el que (+para mi) (=se puede ver)(cómo siguen viviendo ahora $=$ ) [los pueblos originarios] porque parece como que es actual

Document 'N 48', 6 passages, 409 characters.

Section 0, Paragraph 17, 56 characters.

[el video] es aquel que (+para mi) $\left[{ }^{*}\right.$ es*] Muy didáctico

Document 'N 55', 2 passages, 254 characters.

Section 0, Paragraph 8, 145 characters.

(=la sala) es aquella en la que (+para nosotros) los audiovisuales, las imágenes, las voces de los indios traen todo mucho más acá [el presente]

Section 0, Paragraph 9, 109 characters.

Los tejidos son aquellos que (+para nosotros) son cosas más vistas, pero imágenes y

sonidos, esas cosas no...

Document 'N 99', 3 passages, 353 characters.

Section 0, Paragraph 12, 117 characters.

(=la sala) es aquella que ( + a mi) me gusta también que haya algo visual [el video] como que apoye lo que uno lee

\section{CATEGORIAS DE TERCER ORDEN}

\section{III.1. ALUSION AL TIEMPO}

Presente

Document 'N 100', 3 passages, 294 characters.

Section 0, Paragraph 6, 114 characters.

[=el escenario] (=de la sala) es aquel que (+a nosotros) (=nos impactó) cómo están ahora viviendo [los aborígenes]

Document 'N 101', 4 passages, 404 characters.

Section 0, Paragraph 11, 78 characters.

(=el escenario) (=de la sala) es aquel que $(+$ yo) $(=$ no sé si) es la actualidad

Document 'N 2', 3 passages, 194 characters.

Section 0, Paragraph 42, 54 characters.

(= el escenario) Es aquel que (+para mi) es el ahora

Document 'N 35', 2 passages, 219 characters.

Section 0, Paragraph 20, 85 characters.

el escenario de la sala es aquel que (+para mi) (=es) cómo vive la gente humilde hoy. 
Document 'N 4', 13 passages, 1369 characters.

Section 0, Paragraph 27, 181 characters.

(=la sala) es aquella en la que Hay una imagen de una chica con un telar, $\left[{ }^{*} q u e *\right](+$ para mi) [*es*] ver cómo están haciendo ahora y como están viviendo también ahora (=los nativos)

Section 0, Paragraph 53, 118 characters.

(=la sala) es aquella en la que (+para mi) (=está muy bueno) tratar de ver que quedo de eso (=las herramientas) hoy

Document 'N 41', 6 passages, 635 characters.

Section 0, Paragraph 6, 84 characters.

(=la sala) es aquella que [visitándola] (+nosotros) sabemos cómo fueron las culturas

Section 0, Paragraph 8, 149 characters.

(=el video) es aquel en el que (+para mi) (=se puede ver)(cómo siguen viviendo ahora=) [

los pueblos originarios] porque parece como que es actual

Pasado

Document 'N 102', 2 passages, 208 characters.

Section 0, Paragraph 12, 90 characters.

(=la sala) es aquella de la que (+para mi) (=es interesante) lo que fue y de dónde venimos

Document 'N 107', 7 passages, 587 characters.

Section 0, Paragraph 10, 69 characters.

(=el escenario) es aquel que (+yo) supongo que es el paso del tiempo

Section 0, Paragraph 16, 96 characters.

(=el escenario) es aquel que (+para mi) como que lo marca ya (=la parte de la vida) (=que quedó)

Document 'N 111', 4 passages, 410 characters.

Section 0, Paragraph 10, 106 characters.

(=la sala) es aquella de la que (+a mi) (=me llamaron la atención) las cosas que hacían (los aborígenes $=$ )

Document 'N 117', 1 passages, 94 characters.

Section 0, Paragraph 6, 94 characters.

(=la sala) es aquella que (+para mi) está bueno porque muestra las cosas que hicieron antes

Document 'N 126', 1 passages, 82 characters.

Section 0, Paragraph 7, 82 characters.

(=la sala) es aquella que (+para mi) realmente muestra cómo vivían antes los indios

Document 'N 12', 2 passages, 186 characters.

Section 0, Paragraph 10, 85 characters.

(=la sala) es aquella de la que (+a mi) (=me fascinaron) cómo vivían los antepasados

Document 'N 13', 5 passages, 389 characters.

Section 0, Paragraph 5, 69 characters.

El pasado es aquello que $(+$ yo) Creo que la gente no tiene que perder

Document 'N 142', 2 passages, 144 characters.

Section 0, Paragraph 13, 74 characters.

(=el escenario) es aquel en el que (+para mi)(=como que se ve) el progreso

Document 'N 145', 3 passages, 286 characters.

Section 0, Paragraph 7, 78 characters.

(=la sala) es aquella en la que (+para mi) aprendes mucho Sobre nuestra historia

Section 0, Paragraph 8, 95 characters. 
(=la sala) es aquella en la que (+para mi)(=aprendes mucho) sobre cómo se fue formando Argentina

\section{Cambio/historia}

Document 'N 101', 4 passages, 404 characters.

Section 0, Paragraph 6, 130 characters.

(=el mapa) es aquel del que $(+$ yo) no me acuerdo en que siglo dice y en la actualidad como van quedando (=la distribución aborigen)

Section 0, Paragraph 11, 78 characters.

(=el escenario) (=de la sala) es aquel que (+yo) (=no sé si) es la actualidad

Section 0, Paragraph 15, 101 characters.

(=el escenario) (=de la sala) es aquel que (+para mi) [*es*] lo que queda [de los pueblos aborígenes]

Document 'N 102', 2 passages, 208 characters.

Section 0, Paragraph 9, 118 characters.

(=la sala) es aquella de la que (+para mi) es interesante ver lo que han podido juntar que cada vez va desapareciendo

Document 'N 103', 1 passages, 78 characters.

Section 0, Paragraph 5, 78 characters.

(=la sala) es aquella de la que (+a mi) (=me gustó) lo antiguo con lo moderno

Document 'N 110', 4 passages, 349 characters.

Section 0, Paragraph 3, 87 characters.

(=la sala) es aquella de la que A mi me encantó como reflejó así bien toda la historia

Section 0, Paragraph 10, 82 characters.

el escenario] es aquel en el que ( +para mi) se reflejen las condiciones actuales

Document 'N 136', 2 passages, 372 characters.

Section 0, Paragraph 5, 187 characters.

(=la sala) es aquella de la que (+a mi) me llama poderosamente la atención la cronología que tienen ahí de los primitivos pobladores de aquí de Argentina en el siglo XVI y de los actuales

Document 'N 141', 1 passages, 167 characters.

Section 0, Paragraph 10, 167 characters.

(=los mapas) son aquellos en los que ( + a mi) me parece que se entiende bien la idea De cómo después de la conquista se van arrinconando y siendo menos [los aborígenes]

Document 'N 146', 2 passages, 224 characters.

Section 0, Paragraph 6, 104 characters.

(=la sala) es aquella de la que (+a mi)(=me resultó interesante)Como se cuentan cosas de nuestra historia

Section 0, Paragraph 8, 120 characters.

(=la sala)es aquella de la que (+a mi)(=me gustó)la parte donde los mapas muestran donde viven hoy $y$ donde vivían antes

III.2. CULTURA/ IDENTIDAD

\begin{tabular}{|l|l|l|l|l|}
\hline & Nosotros & Otros & Nosotros-otros & Concepto \\
\hline $\begin{array}{l}\text { Cantiada de D.C. } \\
\text { Total de 357 }\end{array}$ & 60 & 83 & 72 & 125 \\
\hline
\end{tabular}

Identidad/ nosotros:

Document 'N 107', 1 passages, 100 characters.

Section 0, Paragraph 21, 100 characters. 
(=la sala) es aquella que (+para mi) (=como todo esto) queda lo nuestro también ahora, en esta época

Document 'N 113', 1 passages, 122 characters.

Section 0, Paragraph 12, 122 characters.

(=el escenario) es aquel en el que (+yo) Supongo que (=hay un celular) [*como*] algo como común denominador de la sociedad

Document 'N 135', 2 passages, 228 characters.

Section 0, Paragraph 6, 87 characters.

(=la sala) es aquella que (+para mi) (=lo invita a uno a mirar) Lo particular que somos

Document 'N 145', 2 passages, 173 characters.

Section 0, Paragraph 7, 78 characters.

(=la sala) es aquella en la que (+para mi) Aprendés mucho Sobre nuestra historia Section 0, Paragraph 8, 95 characters.

(=la sala) es aquella en la que (+para mi)(=Aprendés mucho) sobre cómo se fue formando Argentina

Document 'N 146', 1 passages, 104 characters.

Section 0, Paragraph 6, 104 characters.

(=la sala) es aquella de la que (+a mi)(=me resultó interesante)Como se cuentan cosas de nuestra historia

Document 'N 148', 5 passages, 413 characters.

Section 0, Paragraph 8, 94 characters.

(=la sala) es aquella que (+a mi)me gustó en general por el valor que tiene mostrar lo nuestro

Section 0, Paragraph 9, 90 characters.

(=la sala) es aquella que (+a mi)(=me gustó)(=por el valor que tiene mostrar) lo argentino Section 0, Paragraph 6, 84 characters.

(= el escenario) es aquel que (+ Para mí) [*es*] una síntesis de nuestras costumbres

Document 'N 37', 1 passages, 116 characters.

Section 0, Paragraph 3, 116 characters.

(=la sala) es aquella que (+a mi) me impresiona porque uno no tiene todos los días el contacto con otras culturas

Document 'N 43', 3 passages, 333 characters.

Section 0, Paragraph 16, 130 characters.

este tipo de exposiciones son aquellas que (+para mi) (= habría que hacerlas) en otros

lugares como para no perder nuestras raíces

Document ' $\mathrm{N} 44$ ', 11 passages, 1107 characters.

Section 0, Paragraph 32, 130 characters.

(=en el escenario) es aquel en el que (+para mi) uno (= entiende) [*que*] viene (=a la sala) a buscar un poco parte de su historia

Section 0, Paragraph 46, 61 characters.

(=la sala) es aquella que (+para mi) es parte de lo nuestro

Section 0, Paragraph 47, 64 characters.

(=la sala) es aquella que (+para mi) es parte de lo que nos pasa

Document 'N 60', 2 passages, 194 characters.

Section 0, Paragraph 5, 108 characters.

(=el museo) es aquel del cual ( + a mi) lo que más me gusta es esta parte que tiene que ver mucho con nosotros

Identidad/Otros: 
Document 'N 100', 2 passages, 232 characters.

Section 0, Paragraph 9, 172 characters.

[el escenario] es aquel del cual (=Nos impactó) toda esa mezcla, con esos techos de paja, donde están las vinchucas y por eso [los aborígenes] se siguen muriendo de Chagas

Section 0, Paragraph 13, 60 characters.

[el escenario] es aquel que lo ves en el norte con los tobas

Document 'N 108', 1 passages, 212 characters.

Section 0, Paragraph 8, 212 characters.

(=la sala) es aquella que ( + a mi) Me parece realmente muy interesante sobre todo pienso para los adolescentes [*que*] con un golpe de vista puede entender rápidamente algo sobre la vida de los pueblos aborígenes

Section 0, Paragraph 7, 93 characters.

(=la distribución aborigen) es aquella que (+yo) supongo que cada vez se va ir achicando más

Document 'N 111', 1 passages, 386 characters.

Section 0, Paragraph 21, 386 characters.

(=el escenario) es aquel del que (+para mi) ella dice que es triste y en realidad es triste porque es la realidad del aborigen, reducido a dos chapas, una mezcla sin identidad o relegada, o la identidad esa precisamente de los aborígenes de hoy es quedar en un rincón, ahí reducidos, con todo este espacio que hay (refiere al espacio de la sala) quedar ahí, a un costado de la sociedad

Document 'N 123', 1 passages, 178 characters.

Section 0, Paragraph 7, 178 characters.

(=la sala) es aquella de la que (+a nosotros) (=nos pareció) (=muy interesante) el tema de que ellos [los chicos] (=reconozcan) cómo (=los indígenas) armaban sus cosas para vivir

Document 'N 72', 4 passages, 512 characters.

Section 0, Paragraph 28, 131 characters.

(= la sala) es aquella de la que (+a mi) (=me atrajo mucho) el (=mapa) del siglo XVI y el (=mapa) de ahora de todos los aborígenes

Section 0, Paragraph 29, 187 characters.

(= de la sala) es aquella de la que (+a mi) (=me atrajo mucho) (=los dos mapas) los

indígenas que habitaban la Argentina sobretodo, porque estaban en toda Latinoamérica y en todo el mundo

Document 'N 74', 3 passages, 274 characters.

Section 0, Paragraph 20, 117 characters.

(=todos los pueblos) son aquellos que (+para mi)por lo que se puede apreciar (= han sufrido en la historia universal)

Section 0, Paragraph 21, 87 characters.

(=todos los pueblos) son aquellos que (+para mi) Cada uno con sus sistema (=han sufrido)

Document 'N 75', 2 passages, 279 characters.

Section 0, Paragraph 17, 183 characters.

(=el escenario final)es aquel que (+para mi) [*es*] Como el indígena pero en la actualidad [*porque*] siguen conservando todavía la cultura, pero se mezclan con la que hay ahora nueva

Document 'N 79', 7 passages, 633 characters.

Section 0, Paragraph 19, 104 characters.

Tecnología es aquella que (+para mi)[no era] (=necesaria)[*para*]ellos(los indios $=$ ) porque se adaptaban

Section 0, Paragraph 26, 70 characters.

Los indios son aquellos que (+para mi) se arreglaban con lo que tenían

Section 0, Paragraph 28, 101 characters. 
(=los indios) son aquellos que (+para mi) lo que han ido evolucionando [*porque*] han hecho más cosas

Section 0, Paragraph 33, 71 characters.

(=los indios) son aquellos que (+para mi) Perfecto si podían vivir así

\section{Identidad Nosotros/Otros}

Document 'N 100', 1 passages, 105 characters.

Section 0, Paragraph 8, 105 characters.

[el escenario] el escenario es aquel del cual (=nos impactó) Cómo los hemos confinado [a los aborígenes]

Document 'N 127', 2 passages, 197 characters.

Section 0, Paragraph 22, 87 characters.

[los aborígenes] son aquellos con los que (+para mi)ahora que se nota más la diferencia

Section 0, Paragraph 23, 110 characters.

[los aborígenes] son aquellos que (+para mi) No necesitan a lo mejor de más comodidades como tenemos nosotros

Document 'N 135', 2 passages, 232 characters.

Section 0, Paragraph 5, 107 characters.

(=la sala) es aquella que (+para mí) lo invita uno no a mirar el universo sino precisamente lo particular

Section 0, Paragraph 7, 125 characters.

nosotros somos aquellos que (+para mi) aunque no somos de esta región, obviamente, nosotros también venimos del mismo origen

Document 'N 150', 1 passages, 147 characters.

Section 0, Paragraph 16, 147 characters.

(=el escenario) es aquel que (para mi)(=nos hace pensar) que pasó para que muchos de nuestros hermanos vivan en condiciones que nos son las mejores

Document 'N 35', 1 passages, 112 characters.

Section 0, Paragraph 19, 112 characters.

el escenario es aquel que (+para mi) llegar ahí y ver eso es como que te hace replantear cómo vivimos nosotros

Document 'N 4', 1 passages, 92 characters.

Section 0, Paragraph 15, 92 characters.

(=la sala) es aquella en la que (+para mi ) (=Está re bueno meter más de esas cosas) de todos

Document 'N 47', 2 passages, 237 characters.

Section 0, Paragraph 3, 128 characters.

(=la sala) es aquella que ( + a mi) me parece que para los chicos es interesante ver cómo (+nosotros) empezamos y cómo terminamos

Document 'N 57', 6 passages, 910 characters.

Section 0, Paragraph 9, 121 characters.

(=la sala) es aquella en la que (+para mi) contrastar el país con los indios antiguamente (es realmente impresionante $=$ )

Section 0, Paragraph 10, 150 characters.

(=la sala) es aquella en la que (+para mi) contrastar el país con las culturas antiguas, y con lo que están actualmente, realmente es impresionante

\section{Identidad/concepto:}

Document 'N 100', 1 passages, 144 characters.

Section 0, Paragraph 10, 144 characters. 
[del escenario] es aquel del cual ( + a nosotros) (=Nos impactó toda esa mezcla) conviviendo con dormir en el suelo, con un celular, con Maradona

Document 'N 101', 4 passages, 470 characters.

Section 0, Paragraph 5, 120 characters.

la sala es aquella de la que (+a mi en particular a mi me gustó el mapa que estábamos mirando de la distribución aborigen

Document 'N 101', 4 passages, 470 characters.

Section 0, Paragraph 5, 120 characters.

la sala es aquella de la que (+a mi en particular a mi me gustó el mapa que estábamos mirando de la distribución aborigen

Document 'N 107', 1 passages, 65 characters.

Section 0, Paragraph 18, 65 characters.

(=el escenario) es aquel en el que (+para mi) son todos símbolos

Document 'N 112', 2 passages, 134 characters.

Section 0, Paragraph 11, 68 characters.

(=el escenario) es aquel que (+para mi) es una mezcla de la realidad

Document 'N 122', 1 passages, 116 characters.

Section 0, Paragraph 14, 116 characters.

(=la sala) es aquella de la que (+para mi) (=te causa un poco) lo de esa época con la mezcla de la tecnología de hoy

Document 'N 15', 2 passages, 204 characters.

Section 0, Paragraph 8, 157 characters.

Los indios nuestros son aquellos que (+a mi) todo lo que sean -tanto de 1 norte, como los guaraníes, como los de Tierra del Fuego, los onas- es interesante

Section 0, Paragraph 21, 47 characters.

(=la sala) es aquella que (+para mi) es cultura

Document 'N 16', 1 passages, 71 characters.

Section 0, Paragraph 15, 71 characters.

las cosas [del escenario] son aquellas que (+para mi) Son todas típicas

Document 'N 36', 4 passages, 443 characters.

Section 0, Paragraph 7, 77 characters.

(=la sala)es aquella cuyos (=comentarios) (+para mi) (=son) sobre diversidad

Section 0, Paragraph 10, 126 characters.

(=la sala) es aquella de la que (+a mi) (=me sorprendió) (=esa choza con)[el escanario] la mezcla de lo moderno con lo antiguo

Document 'N 44', 7 passages, 786 characters.

Section 0, Paragraph 3, 159 characters.

(=la sala) es aquella que ( + a mi) Me pareció la verdad que es una vista un poco general de un montón de costumbres sobre todo aborígenes de nuestro territorio

Section 0, Paragraph 36, 93 characters.

(=la sala) es aquella de la cual ( + a mi) la sensación que me queda es cómo todo se transforma

Document 'N 47', 3 passages, 293 characters.

Section 0, Paragraph 7, 92 characters.

(=la sala) es aquella de la que (+ a mi) (=me llamaron la atención) las distintas costumbres

Document 'N 56', 3 passages, 328 characters.

Section 0, Paragraph 3, 98 characters.

(=la sala) es aquella que (+a mi) me gustó porque está destinada un poco a las distintas culturas 
Section 0, Paragraph 4, 99 characters.

(=la sala) es aquella que (+a mi) (me gustó=) [*porque*] está todo junto (=las distintas culturas)

\section{III.3. AUTOREFERENCIA}

\begin{tabular}{|l|l|l|l|}
\hline & Por procedencia & Por conocimiento & Por asociación libre \\
\hline Cantiada de D.C. & 18 & 70 & 44 \\
\hline
\end{tabular}

Por procedencia:

Document 'N 119', 1 passages, 92 characters.

Section 0, Paragraph 13, 92 characters.

(+yo) Tengo mi abuela que es de La Pampa de una familia así indígena y me contó varias cosas

Document 'N 120', 1 passages, 103 characters.

Section 0, Paragraph 6, 103 characters.

(=la sala) es aquella que (+a mi) (=me pareció) Interesante [*porque*] (+Nosotros) De

Bolivia

Por conocimiento:

Document 'N 102', 2 passages, 324 characters.

Section 0, Paragraph 14, 140 characters.

(=la sala)es aquella en la que por lo que me cuentan mis viejos(=de Bolivia) ( + a mi) enseguida me vino a la mente lo del Carnaval de Oruro

Document 'N 12', 2 passages, 209 characters.

Section 0, Paragraph 12, 117 characters.

(=la sala) es aquella en la que me fui a ver la guitarra que habían traído de Europa [*porque*] Yo toco la guitarra

Document 'N 120', 2 passages, 118 characters.

Section 0, Paragraph 11, 59 characters.

(+yo) soy aquel que soy danzante (=del carnaval de Oruro)

Section 0, Paragraph 12, 59 characters.

(+yo) soy aquel que (=en el carnaval de Oruro) [*soy*] toba

Document 'N 127', 1 passages, 82 characters.

Section 0, Paragraph 8, 82 characters.

Yo soy aquella que vivo en la costa del río y me encantan las canoas (=de la sala)

Document 'N 131', 1 passages, 105 characters.

Section 0, Paragraph 3, 105 characters.

(=la sala) es aquella que a mí me pareció interesante porque yo estoy haciendo un profesorado de historia

Document 'N 135', 2 passages, 353 characters.

Section 0, Paragraph 33, 324 characters.

(=los textos)son aquellos de los que ( + a mi) Estos comentarios [que aluden a la identidad] me parecen formidables [*porque*]yo dicto en una especialización en Filosofía Contemporánea, un módulo llamado "Multiculturalismo", y esto (=de los carteles) se parece mucho a lo que dice un filósofo canadiense llamado Charles Tylor

Document 'N 150', 1 passages, 98 characters.

Section 0, Paragraph 6, 98 characters.

(=la sala) es aquella a la que Yo que soy maestra jubilada me hubiese encantado traer a un grado 
Document 'N 18', 1 passages, 140 characters.

Section 0, Paragraph 9, 140 characters.

El tema de los telares es aquel del que yo tengo experiencia más que nada por los tehuelches que el hombre tejía como una ofrenda de amor

Document 'N 37', 3 passages, 385 characters.

Section 0, Paragraph 4, 168 characters.

(=la sala) es aquella que (+a mi) repasando el artículo 75 de la constitución [*como*] abogado- me hizo detener y pensar (que el Estado Nacional haya pensado en eso=)

Document 'N 44', 4 passages, 424 characters.

Section 0, Paragraph 33, 140 characters.

(=la sala) es aquella a la cual (+para mi) (=uno) viene $[* a *]$ entender cómo esas cosas (son todos objetos que nos constituyen como personas $=$ )

Section 0, Paragraph 44, 51 characters.

(+yo) soy aquel que Estoy por terminar sociología.

Por asociación libre

Document 'N 105', 1 passages, 109 characters.

Section 0, Paragraph 12, 109 characters.

(=el escenario) es aquel que ( + a mi) Me hace acordar a la casa cuando vivía con mis abuelos cuando era chico

Document 'N 14', 1 passages, 134 characters.

Section 0, Paragraph 4, 134 characters.

(=la sala) es aquella de la que (+a nosotros) (=lo que más nos gustó) [son] todas las cosas que hacen referencia a la historia de Roca

Document 'N 15', 2 passages, 140 characters.

Section 0, Paragraph 12, 58 characters.

el museo es aquel que $(+$ yo) creo que está pensando en mi

Section 0, Paragraph 14, 82 characters.

(=la sala) es aquella cuya sensación es (+para mi) que uno estás caminando por algo

Document 'N 16', 2 passages, 250 characters.

Section 0, Paragraph 14, 104 characters.

(+nosotros) [al escenario] (=de la sala) es aquel que (+nosotros) comparábamos con el galpón de mi papá

Section 0, Paragraph 19, 146 characters.

el escenario] (=de la sala) es aquel en el que (+para mi) se ve bien reflejado) que usamos(=elementos de las culturas anteriores) en lo cotidiano

Document 'N 4', 5 passages, 600 characters.

Section 0, Paragraph 31, 124 characters.

(= el escenario final) es aquel que (+para mi) mi impresión (=fue el de entrar a una casa) (= muy pobre Con) Lo que uno ama

Document 'N 42', 3 passages, 372 characters.

Section 0, Paragraph 4, 120 characters.

(=la sala) es aquella de la cual (+ a mi) (=lo que más me llamó la atención) [*fueron*]los zapatos que tenían mi nombre

Section 0, Paragraph 5, 133 characters.

(=la sala) es aquella de la cual (+ a mi) (=lo que más me llamó la atención) [*fueron*] las chatitas peruanas porque decían "Claudia"

Document ' $\mathrm{N} 44$ ', 8 passages, 1146 characters. 
Section 0, Paragraph 7, 122 characters.

(=el museo) es aquel en el que $(+\mathrm{A}$ mi)(=me interesa) tratar de encontrar algún origen de cosas que uno hace cotidianamente

Section 0, Paragraph 34, 191 characters.

(=la sala) es aquella a la que (+para mi) (=uno) viene[*a*] entender cómo esta cámara que tengo en la mano o lo que pienso o lo que creo son todos objetos que nos constituyen como personas

Document 'N 59', 1 passages, 65 characters.

Section 0, Paragraph 10, 65 characters.

(=Gardel) es aquel que (+para mi) es el único que me representa

Document 'N 60', 1 passages, 78 characters.

Section 0, Paragraph 20, 78 characters.

(=la sala) es aquella en la cual $(+$ yo) descubrir que uno jugaba juegos arcaico

Document 'N 61', 1 passages, 121 characters.

Section 0, Paragraph 14, 121 characters.

nosotros somos aquellos que (=al bebé) le ponemos acolchado, cunero, que sí el nidito que si no el nidito, que el carrito 
3. Matrices de relaciones.

Se establecen relaciones entre las categorías de primer, segundo y tercer orden, incluyendo subnodos y perfil sociodemográfico

\section{CATEGORIAS DE TERCER ORDEN CON PRIMER ORDEN}

\section{1- Alusión al tiempo/objetos-textos-generalidades de la sala}

\begin{tabular}{|c|c|c|c|}
\hline \multicolumn{4}{|c|}{ Documentos } \\
\hline Matrix Nodes & $\begin{array}{c}(3) \\
\text { /Objetos }\end{array}$ & $\begin{array}{c}(7) \\
/ \text { Textos }\end{array}$ & (8) /Generalidades de la Sala \\
\hline $\begin{array}{l}\text { (1) /Alusión al } \\
\text { tiempo }\end{array}$ & 1 & 3 & 10 \\
\hline \multicolumn{4}{|c|}{ Referencias } \\
\hline Matrix Nodes & $\begin{array}{c}\text { (3) } \\
\text { /Objetos }\end{array}$ & $\begin{array}{c}(7) \\
/ \text { Textos }\end{array}$ & (8) /Generalidades de la Sala \\
\hline $\begin{array}{l}\text { (1) / Alusión al } \\
\text { tiempo }\end{array}$ & 1 & 3 & 13 \\
\hline \multicolumn{4}{|c|}{ Coordenadas } \\
\hline Matrix Nodes & $\begin{array}{l}(3) \\
\text { /Objetos }\end{array}$ & $\begin{array}{l}\text { (7) } \\
\text { /Textos }\end{array}$ & (8) /Generalidades de la Sala \\
\hline $\begin{array}{l}\text { (1) / Alusión al } \\
\text { tiempo }\end{array}$ & 1,1 & 1,2 & 1,3 \\
\hline
\end{tabular}

2- Cultura identidad / objetos -textos-generalidades de la sala

\begin{tabular}{|c|c|c|c|}
\hline \multicolumn{4}{|c|}{ Documentos } \\
\hline Matrix Nodes & (3) /Objetos & (7) /Textos & (8) /Generalidades de la Sala \\
\hline (11)/cultura- identidad & 6 & 4 & 23 \\
\hline & & & \\
\hline \multicolumn{4}{|c|}{ Referencias } \\
\hline Matrix Nodes & (3) /Objetos & (7) / Textos & (8) /Generalidades de la Sala \\
\hline (11)/cultura- identidad & 6 & 4 & 48 \\
\hline \multicolumn{4}{|c|}{ Coordenadas } \\
\hline Matrix Nodes & (3) /Objetos & (7) / Textos & (8) /Generalidades de la Sala \\
\hline (11)/cultura- identidad & 1,1 & 1,2 & 1,3 \\
\hline
\end{tabular}


3- Autorreferencia / objetos - textos - generalidades de la sala

\begin{tabular}{|c|c|}
\hline \multicolumn{2}{|c|}{ Coordenadas } \\
\hline Matrix Nodes & $\begin{array}{c}\text { (2) / } \\
\text { Autorreferencia }\end{array}$ \\
\hline (7) / Textos & 1,1 \\
\hline (3) /Objetos & 2,1 \\
\hline (8) /Generalidades de la Sala & 3,1 \\
\hline \multicolumn{2}{|c|}{ Documentos } \\
\hline Matrix Nodes & $\begin{array}{c}\text { (2) / } \\
\text { Autorreferencia }\end{array}$ \\
\hline (7) / Textos & 3 \\
\hline (3) /Objetos & 8 \\
\hline (8) /Generalidades de la Sala & 16 \\
\hline \multicolumn{2}{|c|}{ Referencias } \\
\hline Matrix Nodes & $\begin{array}{c}(2) / \\
\text { Autorreferencia }\end{array}$ \\
\hline (7) / Textos & 3 \\
\hline (3) /Objetos & 8 \\
\hline (8) /Generalidades de la Sala & 20 \\
\hline
\end{tabular}

\section{CATEGORÍAS DE TERCER ORDEN CON SECTORES}

4- Alusión al tiempo / escenario - máscaras - video

\begin{tabular}{|c|c|c|c|}
\hline \multicolumn{4}{|c|}{ Documentos } \\
\hline Matrix Nodes & (5) /Sector escenario & (4) /Sector máscaras & $\begin{array}{c}(12) \\
\text { /video }\end{array}$ \\
\hline $\begin{array}{c}\text { (1) /Alusión al } \\
\text { tiempo }\end{array}$ & 34 & 0 & 5 \\
\hline \multicolumn{4}{|c|}{ Referencias } \\
\hline Matrix Nodes & (5)/Sector escenario & (4) /Sector máscaras & $\begin{array}{c}(12) \\
\text { /video }\end{array}$ \\
\hline $\begin{array}{l}\text { (1) / Alusión al } \\
\text { tiempo }\end{array}$ & 53 & 0 & 7 \\
\hline \multicolumn{4}{|c|}{ Coordenadas } \\
\hline Matrix Nodes & (5) /Sector escenario & (4) /Sector máscaras & $\begin{array}{c}(12) \\
\text { /video }\end{array}$ \\
\hline $\begin{array}{c}\text { (1) / Alusión al } \\
\text { tiempo }\end{array}$ & 1,1 & 1,2 & 1,3 \\
\hline
\end{tabular}


5- Cultura / identidad por sectores escenario-máscaras-video

\begin{tabular}{|c|c|c|c|}
\hline \multicolumn{4}{|c|}{ Documentos } \\
\hline Matrix Nedes & (5)/Sector escenario & (4)/Sector máscaras & (12) \\
\hline $\begin{array}{c}\text { (11)/cultura- } \\
\text { identidad }\end{array}$ & 35 & 3 & 1 \\
\hline \multicolumn{4}{|c|}{ Referencias } \\
\hline Matrix Nodes & (5) /Sector escenario & (4) /Sector máscaras & $\begin{array}{c}(12) \\
\text { /video }\end{array}$ \\
\hline $\begin{array}{c}\text { (11) /cultura- } \\
\text { identidad }\end{array}$ & 64 & 3 & 1 \\
\hline \multicolumn{4}{|c|}{ Coordenadas } \\
\hline Matrix Nodes & (5) /Sector escenario & (4) /Sector máscaras & $\begin{array}{c}(12) \\
\text { /video }\end{array}$ \\
\hline $\begin{array}{c}\text { (11)/cultura- } \\
\text { identidad }\end{array}$ & 1,1 & 1,2 & 1,3 \\
\hline
\end{tabular}

6- Autorreferencia por referentes de segundo orden, escenario, máscaras y video

\begin{tabular}{|c|c|c|c|}
\hline \multicolumn{4}{|c|}{ Documentos } \\
\hline Matrix Nodes & $\begin{array}{l}\text { (5) /Sector } \\
\text { escenario }\end{array}$ & (4) /Sector máscaras & (12) /video \\
\hline (2) /Autorreferencia & 8 & 2 & 0 \\
\hline \multicolumn{4}{|c|}{ Referencias } \\
\hline Matrix Nodes & $\begin{array}{l}\text { (5) /Sector } \\
\text { escenario }\end{array}$ & (4) /Sector máscaras & (12) /video \\
\hline (2)/Autorreferencia & 13 & 2 & 0 \\
\hline \multicolumn{4}{|c|}{ Coordenadas } \\
\hline Matrix Nodes & $\begin{array}{l}\text { (5) /Sector } \\
\text { escenario }\end{array}$ & (4) /Sector máscaras & (12) /video \\
\hline (2) /Autorreferencia & 1,1 & 1,2 & 1,3 \\
\hline
\end{tabular}


7- Subnodos tiempo (pasado, presente, cambio) / sectores (máscaras, escenario, video)

\begin{tabular}{|c|c|c|c|}
\hline \multicolumn{4}{|c|}{ Coordenadas } \\
\hline Matrix Nodes & $\begin{array}{c}\text { (12) } \\
\text { /video }\end{array}$ & $\begin{array}{l}\text { (5) } / \text { Sector } \\
\text { escenario }\end{array}$ & $\begin{array}{l}\text { (4) } / \text { Sector } \\
\text { máscaras }\end{array}$ \\
\hline $\begin{array}{l}\text { (1 1)/Alusión al } \\
\text { tiempo/Pasado }\end{array}$ & 1,1 & 1,2 & 1,3 \\
\hline $\begin{array}{l}\text { (1 2)/Alusión al } \\
\text { tiempo/Presente }\end{array}$ & 2,1 & 2,2 & 2,3 \\
\hline $\begin{array}{c}\text { (1 3) /Alusión al } \\
\text { tiempo/Cambio historia }\end{array}$ & 3,1 & 3,2 & 3,3 \\
\hline \multicolumn{4}{|c|}{ Documentos } \\
\hline Matrix Nodes & $\begin{array}{c}\text { (12) } \\
\text { /video }\end{array}$ & $\begin{array}{l}\text { (5) } / \text { Sector } \\
\text { escenario }\end{array}$ & $\begin{array}{l}\text { (4) /Sector } \\
\text { máscaras }\end{array}$ \\
\hline $\begin{array}{l}\text { (1 } 1 \text { ) /Alusión al } \\
\text { tiempo/Pasado }\end{array}$ & 2 & 3 & 0 \\
\hline $\begin{array}{l}\text { (1 2) /Alusión al } \\
\text { tiempo/Presente }\end{array}$ & 3 & 22 & 0 \\
\hline $\begin{array}{c}\text { (1 3) /Alusión al } \\
\text { tiempo/Cambio historia }\end{array}$ & 1 & 20 & 0 \\
\hline \multicolumn{4}{|c|}{ Referencias } \\
\hline Matrix Nodes & $\begin{array}{c}(12) \\
/ \text { video }\end{array}$ & $\begin{array}{l}\text { (5) } / \text { Sector } \\
\text { escenario }\end{array}$ & $\begin{array}{l}\text { (4) /Sector } \\
\text { máscaras }\end{array}$ \\
\hline $\begin{array}{l}\text { (1 } 1 \text { ) /Alusión al } \\
\text { tiempo/Pasado }\end{array}$ & 2 & 3 & 0 \\
\hline $\begin{array}{l}\text { (1 2)/Alusión al } \\
\text { tiempo/Presente }\end{array}$ & 5 & 29 & 0 \\
\hline $\begin{array}{c}\text { (1 3) /Alusión al } \\
\text { tiempo/Cambio } \sim \text { historia }\end{array}$ & 1 & 29 & 0 \\
\hline
\end{tabular}




\section{CATEGORÍAS DE TERCER ORDEN POR PERFIL}

\section{8- Identidad/sujeto explícito por sexo}

\begin{tabular}{|c|c|c|c|}
\hline \multicolumn{4}{|c|}{ Documentos } \\
\hline Matrix Nodes & 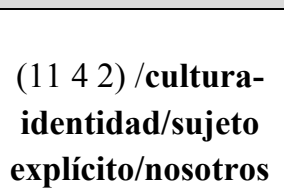 & $\begin{array}{l}\text { (1 } 114 \text { 1 } \\
\text { identidad/cultura- } \\
\text { explícito/otros }\end{array}$ & 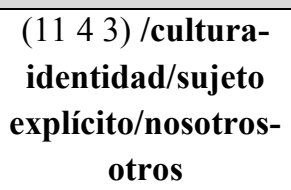 \\
\hline Sexo $=$ femenino & 12 & 27 & 19 \\
\hline Sexo $=$ masculino & 13 & 16 & 12 \\
\hline \multicolumn{4}{|c|}{ Referencias } \\
\hline Matrix Nodes & 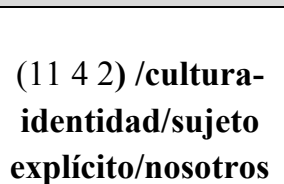 & $\begin{array}{c}\left(\begin{array}{lll}1 & 4 & 4\end{array}\right) \text { /cultura- } \\
\text { identidad/sujeto } \\
\text { explícito/otros }\end{array}$ & $\begin{array}{c}\text { (11 } 143) \text { /cultura- } \\
\text { identidad/sujeto } \\
\text { explícito/nosotros- } \\
\text { otros }\end{array}$ \\
\hline Sexo $=$ femenino & 26 & 58 & 36 \\
\hline Sexo $=$ masculino & 34 & 25 & 36 \\
\hline \multicolumn{4}{|c|}{ Coordenadas } \\
\hline Matrix Nodes & 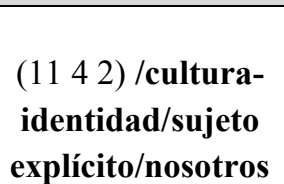 & $\begin{array}{c}\text { (11 } 441) \text { /cultura- } \\
\text { identidad/sujeto } \\
\text { explícito/otros }\end{array}$ & $\begin{array}{c}\text { (11 } 143) \text { /cultura- } \\
\text { identidad/sujeto } \\
\text { explícito/nosotros- } \\
\text { otros }\end{array}$ \\
\hline Sexo $=$ femenino & 1,1 & 1,2 & 1,3 \\
\hline Sexo = masculino & 2,1 & 2,2 & 2,3 \\
\hline
\end{tabular}




\section{9- Identidad- sujeto explícito / instrucción}

\begin{tabular}{|c|c|c|c|}
\hline \multicolumn{4}{|c|}{ Documentos } \\
\hline Matrix Nodes & 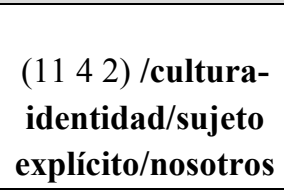 & 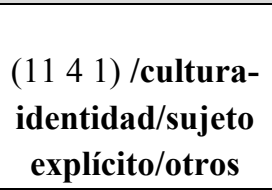 & 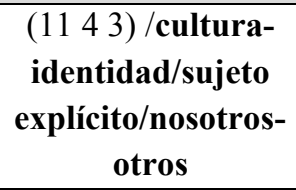 \\
\hline $\begin{array}{c}\text { Instrucción = Not } \\
\text { Applicable }\end{array}$ & 0 & 0 & 0 \\
\hline Instrucción = TI & 1 & 2 & 1 \\
\hline Instrucción $=$ UI & 7 & 8 & 6 \\
\hline Instrucción $=\mathbf{P C}$ & 1 & 1 & 1 \\
\hline Instrucción $=\mathrm{SC}$ & 4 & 6 & 4 \\
\hline Instrucción $=\mathbf{U C}$ & 8 & 13 & 12 \\
\hline Instrucción $=$ TC & 2 & 8 & 4 \\
\hline Instrucción $=$ SI & 2 & 5 & 3 \\
\hline \multicolumn{4}{|c|}{ Referencias } \\
\hline Matrix Nodes & 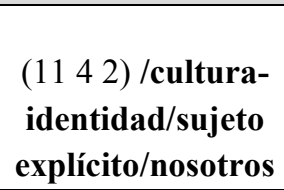 & 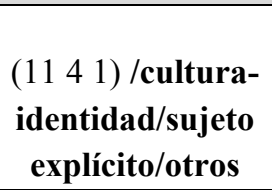 & 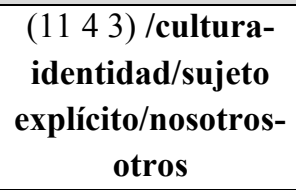 \\
\hline $\begin{array}{c}\text { Instrucción = Not } \\
\text { Applicable }\end{array}$ & 0 & 0 & 0 \\
\hline Instrucción $=$ TI & 2 & 4 & 1 \\
\hline Instrucción = UI & 23 & 15 & 16 \\
\hline Instrucción $=\mathbf{P C}$ & 2 & 1 & 3 \\
\hline Instrucción $=\mathrm{SC}$ & 10 & 9 & 9 \\
\hline Instrucción $=\mathbf{U C}$ & 15 & 22 & 32 \\
\hline Instrucción $=\mathrm{TC}$ & 6 & 19 & 7 \\
\hline Instrucción = SI & 2 & 13 & 4 \\
\hline \multicolumn{4}{|c|}{ Coordenadas } \\
\hline Matrix Nodes & $\begin{array}{c}\left(\begin{array}{lll}1 & 1 & 4\end{array}\right) \text { /cultura- } \\
\text { identidad/sujeto } \\
\text { explícito/nosotros }\end{array}$ & 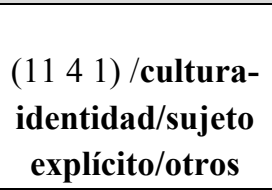 & 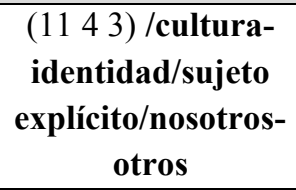 \\
\hline $\begin{array}{c}\text { Instrucción = Not } \\
\text { Applicable }\end{array}$ & 1,1 & 1,2 & 1,3 \\
\hline Instrucción = TI & 2,1 & 2,2 & 2,3 \\
\hline Instrucción = UI & 3,1 & 3,2 & 3,3 \\
\hline Instrucción $=\mathbf{P C}$ & 4,1 & 4,2 & 4,3 \\
\hline Instrucción $=\mathrm{SC}$ & 7,1 & 7,2 & 7,3 \\
\hline Instrucción $=\mathbf{U C}$ & 8,1 & 8,2 & 8,3 \\
\hline Instrucción $=$ TC & 9,1 & 9,2 & 9,3 \\
\hline Instrucción = SI & 10,1 & 10,2 & 10,3 \\
\hline
\end{tabular}


10- Cultura identidad/sujeto explícito/ procedencia

\begin{tabular}{|c|c|c|c|}
\hline \multicolumn{4}{|c|}{ Documentos } \\
\hline Matrix Nodes & 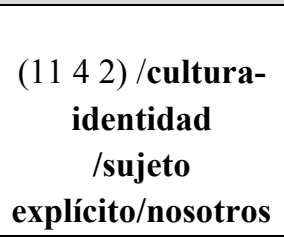 & 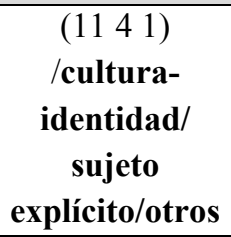 & $\begin{array}{l}\left.\text { (11 } 4 \begin{array}{l}4 \\
\text { identidad/cultura- }\end{array}\right) \\
\text { sujeto } \\
\text { explícito/nosotros- } \\
\text { otros }\end{array}$ \\
\hline Conurbano & 12 & 18 & 10 \\
\hline Interior País & 1 & 4 & 4 \\
\hline Exterior & 3 & 4 & 3 \\
\hline Capital Federal & 4 & 10 & 7 \\
\hline Interior A & 4 & 7 & 7 \\
\hline & & & \\
\hline \multicolumn{4}{|c|}{ Referencias } \\
\hline Matrix Nodes & 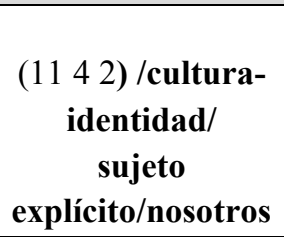 & $\begin{array}{c}\text { (11 } 14 \text { 1) } \\
\text { /cultura- } \\
\text { identidad/ } \\
\text { sujeto } \\
\text { explícito/otros }\end{array}$ & $\begin{array}{l}\text { (11 } 4 \text { 3 }) \text { /cultura- } \\
\text { identidad/ } \\
\text { sujeto } \\
\text { explícito/nosotros- } \\
\text { otros }\end{array}$ \\
\hline Conurbano & 22 & 33 & 31 \\
\hline Interior País & 4 & 12 & 5 \\
\hline Exterior & 5 & 13 & 6 \\
\hline Unassigned & 1 & 0 & 0 \\
\hline Capital Federal & 22 & 12 & 20 \\
\hline Interior BA & 6 & 13 & 10 \\
\hline \multicolumn{4}{|c|}{ Coordenadas } \\
\hline Matrix Nodes & 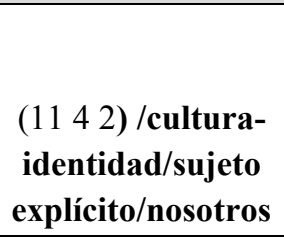 & $\begin{array}{c}\left.\text { (11 } 1 \begin{array}{ll}1 & 4\end{array}\right) \\
\text { /cultura- } \\
\text { identidad/ } \\
\text { sujeto } \\
\text { explícito/otros }\end{array}$ & $\begin{array}{l}\left.\text { (11 } 4 \begin{array}{l}4 \\
\text { identidad/cultura- }\end{array}\right) \\
\text { sujeto } \\
\text { explícito/nosotros- } \\
\text { otros }\end{array}$ \\
\hline Conurbano & 1,1 & 1,2 & 1,3 \\
\hline Interior País & 2,1 & 2,2 & 2,3 \\
\hline Exterior & 3,1 & 3,2 & 3,3 \\
\hline Capital Federal & 5,1 & 5,2 & 5,3 \\
\hline Interior BA & 6,1 & 6,2 & 6,3 \\
\hline
\end{tabular}


11- Cultura identidad/ sujeto explícito /edad

\begin{tabular}{|c|c|c|c|}
\hline \multicolumn{4}{|c|}{ Documentos } \\
\hline Matrix Nodes & $\begin{array}{l}(1142) \text { /cultura- } \\
\text { identidad/sujeto } \\
\text { explícito/nosotros }\end{array}$ & 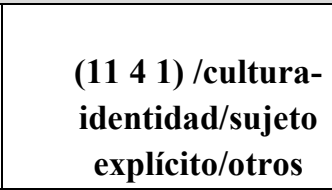 & $\begin{array}{l}\text { (11 } 4 \text { 3) /cultura- } \\
\text { identidad/sujeto } \\
\text { explícito/nosotros- } \\
\text { otros }\end{array}$ \\
\hline GrupoEdad = Unassigned & 0 & 0 & 0 \\
\hline GrupoEdad = de 16 a 25 & 3 & 6 & 4 \\
\hline GrupoEdad = Unknown & 0 & 0 & 0 \\
\hline GrupoEdad = de 56 a 65 & 2 & 2 & 2 \\
\hline GrupoEdad = de 76 a 85 & 0 & 1 & 0 \\
\hline GrupoEdad = de 26 a 35 & 10 & 15 & 11 \\
\hline GrupoEdad = de 66 a 75 & 0 & 2 & 2 \\
\hline GrupoEdad = de 46 a 55 & 3 & 5 & 6 \\
\hline GrupoEdad = de 36 a 45 & 7 & 12 & 6 \\
\hline GrupoEdad = Not Applicable & 0 & 0 & 0 \\
\hline \multicolumn{4}{|c|}{ Referencias } \\
\hline Matrix Nodes & $\begin{array}{l}\left(\begin{array}{ll}11 & 4\end{array}\right) \text { /cultura- } \\
\text { identidad/sujeto } \\
\text { explícito/nosotros }\end{array}$ & $\begin{array}{l}\left(\begin{array}{lll}1 & 4 & 1\end{array}\right) \text { /cultura- } \\
\text { identidad/sujeto } \\
\text { explícito/otros }\end{array}$ & $\begin{array}{l}\text { (11 4 3) /cultura- } \\
\text { identidad/sujeto } \\
\text { explícito/nosotros- } \\
\text { otros }\end{array}$ \\
\hline GrupoEdad = Unassigned & 0 & 0 & 0 \\
\hline GrupoEdad = de 16 a 25 & 5 & 17 & 7 \\
\hline GrupoEdad = Unknown & 0 & 0 & 0 \\
\hline GrupoEdad = de 56 a 65 & 6 & 4 & 6 \\
\hline GrupoEdad $=$ de 76 a 85 & 0 & 1 & 0 \\
\hline GrupoEdad = de 26 a 35 & 28 & 27 & 26 \\
\hline GrupoEdad = de 66 a 75 & 0 & 4 & 2 \\
\hline GrupoEdad = de 46 a 55 & 8 & 11 & 25 \\
\hline GrupoEdad = de 36 a 45 & 13 & 19 & 6 \\
\hline GrupoEdad = Not Applicable & 0 & 0 & 0 \\
\hline \multicolumn{4}{|c|}{ Coordenadas } \\
\hline Matrix Nodes & 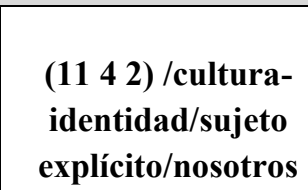 & 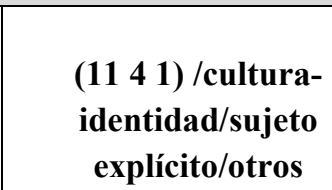 & $\begin{array}{c}\text { (11 } 4 \text { 3 3) /cultura- } \\
\text { identidad/sujeto } \\
\text { explícito/nosotros- } \\
\text { otros }\end{array}$ \\
\hline GrupoEdad = Unassigned & 1,1 & 1,2 & 1,3 \\
\hline GrupoEdad = de 16 a 25 & 2,1 & 2,2 & 2,3 \\
\hline GrupoEdad = Unknown & 3,1 & 3,2 & 3,3 \\
\hline GrupoEdad = de 56 a 65 & 4,1 & 4,2 & 4,3 \\
\hline GrupoEdad $=$ de 76 a 85 & 5,1 & 5,2 & 5,3 \\
\hline GrupoEdad = de 26 a 35 & 6,1 & 6,2 & 6,3 \\
\hline GrupoEdad $=$ de 66 a 75 & 7,1 & 7,2 & 7,3 \\
\hline GrupoEdad $=$ de 46 a 55 & 8,1 & 8,2 & 8,3 \\
\hline GrupoEdad $=$ de 36 a 45 & 10,1 & 10,2 & 10,3 \\
\hline GrupoEdad = Not Applicable & 11,1 & 11,2 & 11,3 \\
\hline
\end{tabular}




\section{RELACIONES CON SUBNODOS}

\section{2-Autorreferencia/edad}

\begin{tabular}{|c|c|}
\hline \multicolumn{2}{|c|}{ Documentos } \\
\hline Matrix Nodes & (2)/Autorerferencia \\
\hline Grupo Edad = de 16 a 25 & 14 \\
\hline Grupo Edad = de 26 a 35 & 18 \\
\hline Grupo Edad = de 36 a 45 & 15 \\
\hline Grupo Edad = de 46 a 55 & 9 \\
\hline Grupo Edad = de 56 a 65 & 1 \\
\hline Grupo Edad = de 66 a 75 & 5 \\
\hline Grupo Edad = de 76 a 85 & 1 \\
\hline \multicolumn{2}{|c|}{ Referencias } \\
\hline Matrix Nodes & (2) /Autorerferencia \\
\hline Grupo Edad = de 16 a 25 & 31 \\
\hline Grupo Edad = de 26 a 35 & 57 \\
\hline Grupo Edad = de 36 a 45 & 34 \\
\hline Grupo Edad = de 46 a 55 & 21 \\
\hline Grupo Edad = de 56 a 65 & 1 \\
\hline Grupo Edad = de 66 a 75 & 9 \\
\hline Grupo Edad = de 76 a 85 & 2 \\
\hline \multicolumn{2}{|c|}{ Coordenadas } \\
\hline Matrix Nodes & (2)/Autorerferencia \\
\hline Grupo Edad = de 16 a 25 & 5,1 \\
\hline Grupo Edad = de 26 a 35 & 4,1 \\
\hline Grupo Edad = de 36 a 45 & 7,1 \\
\hline Grupo Edad = de 46 a 55 & 1,1 \\
\hline Grupo Edad = de 56 a 65 & 6,1 \\
\hline Grupo Edad = de 66 a 75 & 3,1 \\
\hline Grupo Edad = de 76 a 85 & 2,1 \\
\hline
\end{tabular}

\section{3- Autorreferencia /sexo}

\begin{tabular}{|c|c|}
\hline \multicolumn{2}{|c|}{ Documentos } \\
\hline Matrix Nodes & (2) /Autorreferencia \\
\hline Sexo $=$ masculino & 26 \\
\hline Sexo $=$ femenino & 37 \\
\hline \multicolumn{2}{|c|}{ Referencias } \\
\hline Matrix Nodes & (2) /Autorreferencia \\
\hline Sexo $=$ masculino & 77 \\
\hline Sexo $=$ femenino & 78 \\
\hline \multicolumn{2}{|c|}{ Coordenadas } \\
\hline Matrix Nodes & (2)/Autorreferencia \\
\hline Sexo $=$ masculino & 1,1 \\
\hline Sexo $=$ femenino & 2,1 \\
\hline
\end{tabular}


14- Apreciaciones generales del escenario por edad

\begin{tabular}{|c|c|c|}
\hline \multicolumn{3}{|c|}{ Documentos } \\
\hline Matrix Nodes & $\begin{array}{c}\left(\begin{array}{lll}5 & 1 & 1\end{array}\right) / \text { Sector } \\
\text { escenario/apreciaciones } \\
\text { generales/positivas }\end{array}$ & $\begin{array}{c}\left(\begin{array}{lll}5 & 1 & 2\end{array}\right) / \text { Sector } \\
\text { escenario/apreciaciones } \\
\text { generales/negativas }\end{array}$ \\
\hline Grupo Edad = de 16 a 25 & 4 & 6 \\
\hline Grupo Edad = de 26 a 35 & 13 & 6 \\
\hline Grupo Edad = de 36 a 45 & 7 & 10 \\
\hline Grupo Edad = de 46 a 55 & 6 & 1 \\
\hline Grupo Edad = de 56 a 65 & 1 & 2 \\
\hline Grupo Edad = de 66 a 75 & 2 & 0 \\
\hline Grupo Edad = de 76 a 85 & 0 & 0 \\
\hline \multicolumn{3}{|c|}{ Referencias } \\
\hline Matrix Nodes & $\begin{array}{c}\left(\begin{array}{lll}5 & 1 & 1\end{array}\right) / \text { Sector } \\
\text { escenario/apreciaciones } \\
\text { generales/positivas }\end{array}$ & $\begin{array}{c}\left(\begin{array}{lll}5 & 1 & 2\end{array}\right) / \text { Sector } \\
\text { escenario/apreciaciones } \\
\text { generales/negativas }\end{array}$ \\
\hline Grupo Edad = de 16 a 25 & 6 & 8 \\
\hline Grupo Edad = de 26 a 35 & 24 & 10 \\
\hline Grupo Edad = de 36 a 45 & 20 & 23 \\
\hline Grupo Edad = de 46 a 55 & 8 & 1 \\
\hline Grupo Edad = de 56 a 65 & 2 & 5 \\
\hline Grupo Edad = de 66 a 75 & 2 & 0 \\
\hline Grupo Edad = de 76 a 85 & 0 & 0 \\
\hline \multicolumn{3}{|c|}{ Coordenadas } \\
\hline Matrix Nodes & $\begin{array}{c}\left(\begin{array}{lll}5 & 1 & 1\end{array}\right) / \text { Sector } \\
\text { escenario/apreciaciones } \\
\text { generales/positivas }\end{array}$ & $\begin{array}{c}\left(\begin{array}{lll}5 & 1 & 2\end{array}\right) / \text { Sector } \\
\text { escenario/apreciaciones } \\
\text { generales/negativas }\end{array}$ \\
\hline Grupo Edad = de 16 a 25 & 8,1 & 8,2 \\
\hline Grupo Edad = de 26 a 35 & 2,1 & 2,2 \\
\hline Grupo Edad = de 36 a 45 & 4,1 & 4,2 \\
\hline Grupo Edad = de 46 a 55 & 6,1 & 6,2 \\
\hline Grupo Edad = de 56 a 65 & 1,1 & 1,2 \\
\hline Grupo Edad = de 66 a 75 & 7,1 & 7,2 \\
\hline Grupo Edad = de 76 a 85 & 3,1 & 3,2 \\
\hline
\end{tabular}


15- Apreciaciones generales positivas y negativas del escenario/ instrucción

\begin{tabular}{|c|c|c|c|}
\hline \multicolumn{4}{|c|}{ Documentos } \\
\hline Matrix Nodes & $\begin{array}{c}\left(\begin{array}{lll}5 & 1 & 1\end{array}\right) / \text { Sector } \\
\text { escenario/ } \\
\text { apreciaciones } \\
\text { generales/positivas }\end{array}$ & $\begin{array}{c}\left(\begin{array}{lll}5 & 1 & 1\end{array}\right) / \text { Sector escenario/ } \\
\text { apreciaciones } \\
\text { generales/positivas }\end{array}$ & 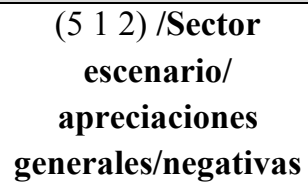 \\
\hline 1 Instrucción = PC & 3 & 3 & 0 \\
\hline 2 Instrucción = SI & 3 & 3 & 0 \\
\hline 3 Instrucción = SC & 7 & 7 & 5 \\
\hline 4 Instrucción = TI & 0 & 0 & 1 \\
\hline 5 Instrucción = TC & 6 & 6 & 5 \\
\hline 6 Instrucción = UI & 7 & 7 & 6 \\
\hline 7 Instrucción = UC & 7 & 7 & 8 \\
\hline \multicolumn{4}{|c|}{ Referencias } \\
\hline Matrix Nodes & $\begin{array}{c}\left(\begin{array}{lll}5 & 1 & 1\end{array}\right) / \text { Sector } \\
\text { escenario/ } \\
\text { apreciaciones } \\
\text { generales/positivas }\end{array}$ & $\begin{array}{c}\left(\begin{array}{lll}5 & 1 & 1\end{array}\right) / \text { Sector escenario/ } \\
\text { apreciaciones } \\
\text { generales/positivas }\end{array}$ & 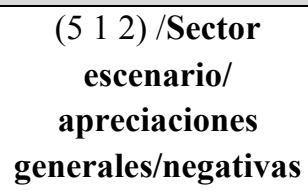 \\
\hline 1 Instrucción = PC & 3 & 3 & 0 \\
\hline 2 Instrucción = SI & 7 & 7 & 0 \\
\hline 3 Instrucción = SC & 10 & 10 & 8 \\
\hline 4 Instrucción = TI & 0 & 0 & 1 \\
\hline 5 Instrucción = TC & 19 & 19 & 6 \\
\hline 6 Instrucción = UI & 16 & 16 & 9 \\
\hline 7 Instrucción = UC & 7 & 7 & 23 \\
\hline \multicolumn{4}{|c|}{ Coordenadas } \\
\hline Matrix Nodes & $\begin{array}{c}\left(\begin{array}{lll}5 & 1 & 1\end{array}\right) / \text { Sector } \\
\text { escenario/ } \\
\text { apreciaciones } \\
\text { generales/positivas }\end{array}$ & $\begin{array}{c}\left(\begin{array}{lll}5 & 1 & 1\end{array}\right) / \text { Sector escenario/ } \\
\text { apreciaciones } \\
\text { generales/positivas }\end{array}$ & 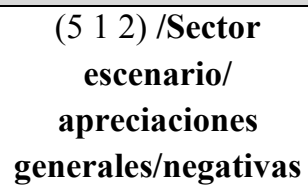 \\
\hline 1 Instrucción = PC & 5,1 & 5,1 & 5,2 \\
\hline 2 Instrucción = SI & 2,1 & 2,1 & 2,2 \\
\hline 3 Instrucción = SC & 6,1 & 6,1 & 6,2 \\
\hline 4 Instrucción = TI & 3,1 & 3,1 & 3,2 \\
\hline 5 Instrucción = TC & 4,1 & 4,1 & 4,2 \\
\hline 6 Instrucción = UI & 7,1 & 7,1 & 7,2 \\
\hline 7 Instrucción = UC & 1,1 & 1,1 & 1,2 \\
\hline
\end{tabular}


Capítulo VII

CONSIDERACIONES FINALES 
Más de 400 piezas suspendidas en soportes de acrílico, protegidas de los daños de la luz, acomodadas en lugares especiales buscando el contraste, la belleza, el mensaje. Signos de memoria, códigos de encuentro, reconstrucciones fragmentadas. Un recorrido lineal pero intenso, con saltos lúdicos, con sorpresa, admiración, conocimiento.

Más de 50 personas dedicadas con profesionalismo a la conjugación de una tarea interdisciplinaria. Técnicos, museólogos, investigadores, estudiantes, artistas, administradores, construyendo un espacio acabado en el que se entrelazan ideas, dibujos, habilidades.

Más de 20 pueblos originarios de Argentina y América con quienes aprender a percibir la diversidad de las formas de entender el mundo, cuidar la naturaleza, vincularse con la tierra, la vida y la muerte. Textiles, danza, música, comida, máscaras, mantas, bolsas, fajas, adquieren nuevos significados en las salas del museo. Ellos son una herramienta poderosa para la reflexión y quizás, los que miran, despojados del etnocentrismo, comprendan su presencia, sus derechos, sus reclamos y respeten los sentidos ancestrales del existir.

Una institución de más de cien años que camina hacia la modernización de sus formas expositivas, donde es posible experimentar un abanico de sensaciones $e$ interpretaciones. Donde se busca que el conocimiento especializado llegue a todos los públicos posibles, para elevar su misión educativa.

Espejos culturales es un espacio para recordar que nuestro mundo no existe en un sentido unívoco. Un espacio que anclado en las raíces del pasado, configura en el presente identidades dinámicas amalgamadas por sentimientos de pertenencia, de comunidad, donde es posible reconocernos en un mundo pluricultural.

¿Qué cosas pondría en una vitrina que nos cuente algo sobre Ud.?

Si pensamos en esta pregunta es evidente que exhibir la cultura de los "otros" será siempre un desafio, requiere de una cuidadosa ética de la representación basada en el respeto. Sin duda el futuro encontrará en los museos un lugar de mayor protagonismo para todos. Alli estaremos.

M.M.R. 


\section{Capítulo VII: consideraciones finales}

Las exhibiciones son espacios poderosos de divulgación científica a la vez que herramientas de cambio social. Destinadas al público general, conjugan recursos para constituir un campo intersemiótico y producir múltiples mensajes que se yuxtaponen e interrelacionan, configurando una compleja trama conceptual. Estas pueden ser concebidas y analizadas como producciones discursivas cuyas estrategias comunicativas descansan siempre en un conjunto de supuestos, más o menos explícitos, desde los que se contextualizan las colecciones, otorgándoles su condición de bien patrimonial.

Cuando un objeto sale de su contexto original e ingresa al museo, circula por una serie de instancias de re-significación desde las cuales adquiere su valor de signo, es decir, es susceptible de ser interpretado. En el conjunto de las semiosis sustituyentes, en el contexto de la exhibición, éste forma parte de las estrategias discursivas de un espacio tridimensional a través del cual se pretende promover en los visitantes una experiencia cognitiva, emocional y lúdica.

Los objetos de carácter etnográfico son embestidos de autenticidad desde el contexto de recolección y constituyen el fundamento de la re-presentación de otras culturas en las salas de exhibición. En sus orígenes los museos antropológicos cumplieron un rol destacado en la definición de la disciplina, siendo la exhibición de la cultura material el producto de las recolecciones del trabajo de campo y los objetos la evidencia de la cultura de los "otros".

En la actualidad se ha producido una suerte de inversión de esta trayectoria. La exhibición ya no es la culminación de una tarea de investigación iniciada en el campo, sino el principio de una nueva secuencia de análisis. En esta se asume la intervención de los sujetos/intérpretes, la explicitación del conjunto de supuestos que sustentan la instancia de re-presentación, los procedimientos teórico-metodológicos en la construcción de sentido, las estrategias y dispositivos museográficos y el análisis de los modos de apropiación por parte de los visitantes.

La crítica antropológica ha puesto en evidencia la relatividad de los resultados en la construcción del conocimiento, desafiando la relación isomórfica entre objeto referente y su descripción/interpretación. Se ha hecho cada vez más evidente el rol del etnógrafo intérprete, abocado siempre a la descripción exhaustiva de la diversidad cultural. El pasaje objetivación / representación queda supeditado al proceso de génesis 
de la interpretación en una situación dada, donde los datos predican sobre los hechos, pero no los contiene. En esta tesis, una mirada analítica sobre el tema, permite ver que uno de los tópicos a considerar es el de revisar esa etnografía realista de la primera época para incorporar una mirada constructivista que, finalmente, impregna todas las instancias de construcción de sentido, reconociendo, para cada una de ellas, sus objetos, principios, estrategias de producción e intérpretes. En este caso, han sido identificados tres contextos, denominados como de recolección, de re-presentación y de apropiación. Las relaciones intercontextuales son de carácter dialógico, relacional y sistémico. El primer contexto otorga al objeto la condición de etnográfico, para lo cual alude a las prácticas de campo propias de la etnografía; el segundo, sus posibilidades de representación, es decir, la materialización intersemiótica de las intenciones de los curadores fundamentadas en los supuestos antropológicos acerca de los "otros"; el tercero, las formas en que los visitantes construyen un conocimiento acerca de los "otros", producto de la visita a la exhibición, como experiencia situada.

El pasaje del contexto de recolección al contexto de re-presentación no será nunca exhaustivo en el sentido de "verdadero", sino que será siempre el recorte más o menos explícito realizado por los curadores y el reflejo de sus intenciones para con el público, en el marco de una política institucional. Es aquí donde la instancia de representación se subsume al conocimiento etnográfico, a su vez lo recrea, lo traduce y transforma, lo hace perceptible en un nuevo espacio para la puesta en valor de las dimensiones estéticas, históricas y culturales de los objetos de colección. Las nuevas estrategias discursivas incorporan elementos aleatorios, abiertas a diferentes lecturas e interpretaciones; generan rupturas en el recorrido, apelan a la comparación, la proyección y promueven estados emocionales. El conocimiento es cuestionable, el producto final no es ni "verdadero" ni "falso", sino el resultado de un delicado equilibrio entre la ambigüedad y la certeza.

Con cierto riesgo de simplificación, podemos agrupar las propuestas de innovación de exhibiciones etnográficas actuales según prevalezca la variable estética, descriptivo/etnográfica o histórico/política. En el primer caso, se apela a la experiencia sensible, el objeto está deliberadamente despojado de su condición de representación etnográfica y las estrategias expositivas ponen de relieve las cualidades materiales y estéticas del mismo, resaltando su condición de objeto único. Otras propuestas desplazan el centro de atención del objeto hacia el contexto, éste ocupa un lugar dentro 
de un sistema de relaciones. Las estrategias museográficas buscan reconstruir escenas con diverso grado de realismo. En ellas prevalece la variable descriptiva y disciplinar.

Otras experiencias se hacen eco de los actuales debates acerca de los derechos y reclamos de los pueblos originarios. Se pone énfasis en la variable política e histórica, se busca confrontar la historia oficial incorporando nuevas miradas y en algunos casos la concreta participación de miembros de las comunidades en la definición de criterios expositivos. El análisis exhaustivo de los resortes que sustentan cada forma expositiva escapa a los objetivos de este trabajo pero sin duda es una de las líneas de investigación que quedan abiertas para una profunda indagación, asumiendo siempre la complejidad de la expografía. De todas maneras, se hace evidente que a través de las distintas retóricas los museos tienden a ser cada vez más "transparentes", en tanto buscan sacar a la luz las claves teóricas, ideológicas y políticas que legitiman su accionar. Sin embargo, en tanto y en cuanto la crítica se cierre en la reflexión intradisciplinar estaremos lejos de aportar a una política institucional. Olvidar la función comunicativa de las exhibiciones y la misión educativa del museo implica mutilar el ejercicio de uno de sus objetivos primordiales. En este sentido, el estudio del modo en que los visitantes perciben, recepcionan y procesan los mensajes propuestos a través de la exhibición constituye la otra cara indisoluble del circuito comunicacional. En esta tesis, la configuración de un modelo relacional entre el dominio de la re-presentación y el de la apropiación, dado a partir del caso concreto de la exposición "Espejos Culturales", pretendió ofrecer un instrumento metodológico de evaluación de exhibiciones, de tipo cualitativo bajo el precepto de concebir al visitante como un sujeto activo e histórico que pone "en acción" su capital cultural. Conocer los "mundos semióticos posibles" para una comunidad dada a partir de una experiencia situada permite indagar acerca del umbral de ambigüedad que es posible maniobrar para asumir la diversidad, sin perder de vista la búsqueda intencional de los objetivos que persigue una exposición.

La experiencia de la visita es multidimensional, se abre al público diverso estableciendo canales múltiples de interconexión que superan las barreras de los niveles de instrucción, donde cada visitante configura su propia síntesis cognitiva y emocional. Entre los tópicos a destacar en esta situación de aprendizaje se encuentra la fuerza particular de los objetos de colección ligada a su autenticidad, la autorreferencialidad como posibilidad de proyección al mundo cotidiano del visitante, el equilibrio en la puesta museográfica ente forma y contenido abriendo mayores canales de acceso y el 
rol de una propuesta diferencial durante el recorrido, generando rupturas perceptivas y niveles conceptuales de diverso grado de inclusión.

Está claro que no existe una solución fácil para "el problema de la representación”. Ni la experiencia del público ni la autoridad curatorial son dueñas de un derecho automático a la contextualización de las colecciones en las salas de exhibición.

A través del estudio de visitantes la sala de exhibición etnográfica se percibe como un espacio que promueve una experiencia de contemporaneidad a través de la cual se otorga visibilidad a las comunidades, aportando a la comprensión de la diversidad y sus valores. Los museos que incluyen materiales etnográficos deben trabajar duro para revertir su imagen, teñida de la historia de apropiaciones en los marcos colonialistas. Para esto es pertinente el cambio que éstos han sufrido transformándose en museos foro, abiertos al diálogo, más participativos generando un ámbito de co-gestión. Así, el patrimonio se abre a un abanico de significación y adquiere una nueva historicidad.

En este sentido, esta tesis es sólo un punto de partida donde se buscó problematizar el proceso de génesis de la interpretación, asumir la intervención de los diversos sujetos/intérpretes, tanto en la producción como en la apropiación de sentidos y así aportar al diseño de una "ética de la re-presentación”. 


\section{BIBLIOGRAFÍA}

- ADAMS, M. 1984. Mediatizar nuestro saber. Museum. XXXVI. Consejo Internacional de Museos.

- AGAR, M. 1991. Hacia un lenguaje etnográfico. En: El surgimiento de la antropología posmoderna. México, Gedisa.

- ALAIN NICOLAS (comp.). 1985. Muséologie Nouvelle et Expérimentation Social. Marsella.

- ALMARZAR RISQUEZ, F. 2002. El Museo como propuesta de significaciones: una estructura sistémica no impositiva, abierta y caótica. En: Revista Digital Nueva Museología. http///www.nuevamuseología.com.ar/Museosign.htm

- ALMEIDA, M. A. 2005. O contexto do visitante na experiencia museal: semelhancas e diferentas entre museus de ciencia e de arte. En: Museus e Ciencias; Vol. 12, pp. 3153, Río de Janeiro, História, Ciencias, Saúde. Dossie $4^{\circ}$ Congresso Mundial de Museus e Centros de Ciencia.

- AMES, Michel M. 1994. The Politics of Difference: Other voices in a Net Yes Postcolonial Word. Museum Anthropology, 18 (3), pp. 9-17. American Anthropological Associationl Journal of the council for Museum Anthropology.

- AMES, Michel M. 1999. "How to Decorate a House: the Re-Negociation of Cultural Representations at the University of British Columbia Museum of Antrhropology". Museum Anthropology, (22) 3, pp. 41-51.

- AMES, Michel M. 2004. Museología: la interrupción. En: Museum internacional. Diversidad cultural y patrimonio. UNESCO. Sept. 2004, N 227, pp. 39-45.

- AMES, Michel. 1986. Museum, the public, and Anthropology. A Study in the Anthropology of Anthropology. Vancuver: University of British Columbia Press.

- AMES, Michel. 1991. Biculturalism in Exhibitions. Museum Anthropology, 15 (2), pp. 7-15.

- APPADURAI, A. 1991. La vida social de las cosas. Perspectiva cultural de las mercancías. México, Grijalbo.

- ARANTES, Augusto A. 1999. Desigualdad y diferencia. Cultura y ciudadanía en tiempos de globalización. En: La dinámica local/global. Cultura y comunicación: nuevos desafíos. Ed. Ciccus, pp. 145-169. 
- ARIZPE, Lourdes y E. Nalda. 2002. Cultura, patrimonio y turismo. En: Iberoamérica, diagnóstico y propuestas para el desarrollo cultural. N. García Canclini coordinador. Buenos Aires. Santillana, pp. 209-234.

- ARNOLD, Marcelo. 2000. Teoría de sistemas y sociología: los desafíos epistemológicos del constructivismo. En: Revista de Ciencias Sociales, Chile, Universidad Arturo Prat, No 10, pp. 87-108.

- ASEnSIO, M. y Pol, E. 1991. Nuevos escenarios para la interpretación del patrimonio: el desarrollo de programas públicos. Madrid, Universidad Autónoma, Departamento de Psicología.

- ASENSIO, Mikel; Pol, Elena. 1996. Cuando la mente va al museo: un enfoque cognitivo-receptivo de los estudios de público. Actas de las IX Jornadas de los DEAC, Universidad Autónoma de Madrid.

- ASENSIO, Mikel; Pol, Elena y otros. 1998. El proyecto "Público y Museos". Seminario internacional sobre estudios de visitantes de museo y evaluación de exposiciones. Museo José Hernández (GCBA).

- ASENSIO, Mikel. 1998. El desarrollo de programas públicos en el Museo. Seminario internacional sobre estudios de visitantes de museo y evaluación de exposiciones. Museo José Hernández (GCBA).

- AUGE, Marc. 1996. El sentido de los otros. Actualidad de la antropología. Buenos Aires. Paidós.

- AUGE, Marc. 1998. Las formas del olvido. Barcelona, Gedisa.

- AUGE, Marc. 1999. La vida como relato En: La dinámica local/global. Cultura y Comunicación: Nuevos Desafíos. Ed. Ciccus, pp. 173-184.

- AUGE, Marc. 2001. Ficciones de fin de siglo. Barcelona, Gedisa.

- AUSUBEL, D. P. 1983. Novak, J y Hanesian, H. Psicología Educativa. Un punto de vista cognoscitivo. México. Trillas.

- BARTOLOMÉ, M. 2003. En defensa de la etnografía. El papel contemporáneo de la investigación intercultural. En: Revista de Antropología Social. México, Instituto Nacional de Antropología e Historia, 12, pp. 199-222.

- BAYARDO, R. Y M. Lacarrieu. 1999. Presentación. Nuevas Perspectivas sobre la cultura en la dinámica local/global. En: La dinámica local/global. Cultura y comunicación: nuevos desafíos. Ed. Ciccus, pp. 9-23.

- BATESON, G. 1976. Pasos hacia una ecología de la mente. Buenos Aires, Ed. Lolhlé. 
- BATESON. G. 1989. El telégrafo y la orquesta. En: La nueva comunicación. Barcelona, Ed. Kairós, pp. 11-25.

- BATESON, G. 1990. Espíritu y naturaleza. Buenos Aires, Amorrortu.

- BAUMAN, Zymunt. 1999. La Globalización. Consecuencias humanas. Brasil, Fondo de Cultura Económica.

- BERGERON, Yves. 2002. Le «Complexe » des musées d’Ethnographie et d'ethnologie au Québec, 1967-2002. En: Rev. Ethnologies, Vol.24, N² 2, Association Canadienne d'Ethnologie.

- BERGERON, Yves. 2007. Du Musée de l'Homme du Québec au Musée de la civilisation. Transformations des musées d'ethnographie au Québec. Rev. Dialent, № 9, España, Universidad de La Rioja.

- BIALOGORSKI, Mirta y Erica Lander. 1999. "Viejas ideas, nuevos públicos: acerca de un estudio de público en el Museo Hernández" Comunicación en "Museos y diversidad cultural - Viejas culturas, nuevos mundos" VII SEMINARIO LATINOAMERICANO SOBRE PATRIMONIO CULTURAL, ICOM-CA" Buenos Aires. www.museohernandez.org.ar

- BIALOGORSKI, Mirta y Ana Cousillas. 2000. "Gestión cultural y estudios de Público en el Museo José Hernández". Cuadernos de Antropología Social 12: pp.195-205. Universidad de Buenos Aires. Buenos Aires, Argentina.

- BIALOGORSKI, Mirta. 2002. Una perspectiva semiótica en el diseño de una muestra museográfica. V Congreso Internacional de la Federación Latinoamericana de Semiótica. Semiótica de la vida cotidiana. www.museohernandez.org.ar

- BIALOGORSKI, Mirta y Cousillas Ana. 2004. Métodos cualitativos y etnográficos en tareas de gestión: el Museo de Arte Popular José Hernández (GCBA) y el Banco de la Memoria en el Campo Artesanal. IV Jornadas de Etnografía y Métodos Cualitativos. Instituto de Desarrollo Económico y Social (IDES).

- BIALOGORSKI, Mirta. 2007. Campo semiótico y campo artesanal: el juego de las transformaciones y los bordes. Ponencia presentada en la Mesa Redonda: Los bordes de la semiótica. Congreso Mundial de la Asociación Internacional de Semiótica. Comunicación: comprensión/incomprensión. Helsinki-Imatra- Finlandia, junio de 2007.

- BITGOOD, S.; SHETTEL, H. 1996. An overview of visitor studies. Journal of Museum Education, pp.6-10.

- BLALOCK, H. 1986. Estadística Social. Fondo de Cultura Económica, México.

- BODRILLARD, J. 1999. El sistema de los objetos. España, Siglo XXI. 
- BOURDIEU, P. y Wacquant. J.D. 1995. Respuestas por una antropología reflexiva. México. Grijalbo.

- BOURDIEU, P. 1996. Cosas Dichas. Gedisa, Barcelona, España.

- BOURDIEU, P. 1998. La distinción. Criterio y bases sociales del gusto. Buenos Aires, Taurus.

- BOURDIEU, P. y DARBEL Alain. 2004. El amor al arte. Los museos europeos y su público. Bs. As. Paidós.

- BOURDIEU, P.; Chamberon, J. C. y Passeron J. C. 2008 (1ra. Ed. 1975). El oficio de sociólogo. Presupuestos epistemológicos. Buenos Aires, Siglo XXI.

- BRUNER, J. 1988. Realidad Mental y Mundos Posibles. Los actos de la imaginación que dan sentido a la experiencia. Barcelona, Gedisa.

- BROWN, E. 1999. Los museos hoy. En: Lo Público y lo Privado en la Gestión de Museos. Alternativas institucionales para la gestión de museos. Buenos Aires, Fondo Nacional de las Artes/ Fundación Antorchas/ Fondo de Cultura Económica, pp.19-40.

- BROMBERGER, C. 1979. Technologie et analyse sémantique des objets: pour une sémio technologie. L'Homme, XIX(1): pp.105-140.

- BROMBERGER, C. ET CHEVALLIER, D. 1999. Carrières d'objets, Paris, MSH.

- BOVIN, Mauricio F.; Rosto A.; Arribas, V. 2007. Constructores de Otredad. Una introducción a la antropología social y cultural. Buenos Aires, Editorial EA.

- CANDEAU, Joel. 2001. Memoria e identidad. Buenos Aires, Ediciones del Sol, Serie Antropológica.

- CARRETERO PÉREZ, Andrés. 1996. Antropólogos y Museos Etnográficos. En: Complutum Extra, 6 (II): pp. 329-336, Madrid, Museo Nacional de Antropología.

- CARRILLO TRUEBA, César. 2003. Propuestas para un museo de historia natural del siglo XXI. En: Elementos, Ciencia y Cultura, 2002-2003; № 48, col.9.

- CASALLA, M. 1997. Los dilemas del laberinto. Vida, pensamiento y creatividad en tiempos ambiguos. En Globalización e identidad cultural. Buenos Aires, Ediciones Ciccus, Primera parte, pp. 61-75.

- CASUllO, Nicolás. 1991. Modernidad, biografía del ensueño y la crisis (introducción a un tema). En: El debate modernidad pos-modernidad. Buenos Aires, Ed. Puntosur, pp. 11-63.

- CASUllO, Nicolás; Forser, R., Kaufman, A. 2004. Itinerarios de la Modernidad. Corrientes del pensamiento y tradiciones intelectuales desde la ilustración hasta la posmodernidad. Buenos Aires, Eudeba. 
- CLIFFORD, J. 1985. Objects and Selves - an Afterword. En: Objects and Others. Essays on Museums and Material Culture. The University of Wisconsin Press, USA, History of Anthropology, Vol. 3: pp. 236-246.

- CLIFFORD, J. y MARCUS, G. 1991. Retóricas de la antropología. Madrid, Ed. Jucar.

- CLIFFORD, J. 1991. Sobre la autoridad etnográfica. En: El surgimiento de la antropología posmoderna. México, Gedisa.

- CLIFFORD James y George Marcus. 1991. Retóricas de la Antropología. Barcelona, Júcar.

- CLIFFORD, J. 1996. Dilemas de la Cultura. Antropología, literatura y arte en la perspectiva posmoderna. España, Gedisa.

- CLIFFORD, J. 1999. Itinerarios transculturales. Barcelona. Gedisa.

- COLLOMB Gérard. 1999. Ethnicité, nation, musée, en situation postcoloniale. En: Revue Ethnologie Française, No 3. Société d'Ethnologie Française.

- COLINVAUX, Dominique. 2005. Museus de Ciencias e psicologia: interatividade, experimentação e contexto. Ciencias e educação em museus no final do século XIX. En: Museus e Ciencias, Vol. 12, 2005: pp. 79-91, Río de Janeiro, História, Ciencias, Saúde. Dossie $4^{\circ}$ Congresso Mundial de Museus e Centros de Ciencia.

- COROMINAS, María. 2001. Los estudios de recepción. Portal de la comunicación. Barcelona, Instituto de comunicaciones de la Universidad Autónoma de Barcelona. Aula Abierta/ Lecciones básicas.

- COUSILlAS, A. M. 1997. Los Estudios de Visitantes a Museos. Fundamentos generales y principales tendencias. Buenos Aires. En: www.naya.org.ar

- CUCHE, Denys. 2002. La noción de cultura en las ciencias sociales. Buenos Aires, Nueva Visión.

- CURY, M. X. 1999. Museología y Filosofía: Dewey, Pessanha e Platao, Foucault e Habermas. Edited by Hildegard K. Vieregg. ICOFOM (International Committee for Museology), Venezuela.

- CURY, M. X. 2005. Comunicasao e pesquisa de recepção: uma perspectiva teórica metodológica para os museus. En: Museus e Ciencias, Vol. 12, 2005, pp. 365-380, Río de Janeiro, História, Ciencias, Saúde. Dossie $4^{\circ}$ Congresso mundial de Museus e Centros de Ciencia.

- DELOCHE, B. 2002. El Museo Virtual. Hacia una ética de las nuevas imágenes. España, Ediciones Trea. 
- DESCOLA, Ph. 2005. Más allá de la naturaleza y de la cultura. En: Etnografías Contemporáneas, Universidad Nacional de San Martín, Año 1(1): pp. 93-114.

- DESVEAUX, Emmanuel. 2002. Le musée du Quai Branly ou miroir de ses prédécesseurs. En: Ethnologies Musés, Vol.24, No 2, Association Canadiens d'Ethnologie et de Folklore.

- DIAZ VIANA, L. 1991. Retóricas de la Antropología. Prólogo a la Edición Española. Barcelona, Ed. Jucar, pp.9-20.

- DUBUC, Eise. 1998. Le futur antérieur du Musée de 1'Homme. En: Gradhiva, Revieu d'Histoire et $\mathrm{d}$ archives de l'anthropologie, $\mathrm{N}^{\mathrm{o}} 24$, pp. 71-92, Centre National du Livre, Paris.

- DUJOVNE, M. 1995. Entre Musas y Musarañas. Una visita al museo. Argentina, Fondo de Cultura Económica.

- ECO, U. 1979. Obra abierta. Barcelona, Planeta-Agostini.

- ECO, U. 1994. Signo. Colombia, Grupo Editor Quinto Centenario.

- ENDERE, María Luz. 2009. Algunas reflexiones acerca del patrimonio. En: Patrimonio, ciencia y comunidad: su abordaje en los partidos de Azul, Olavarría y Tandil. Ed. INCUAPA, Olavarría, pp. 19-46.

- ETXEVERRÍA, Xavier. 2000. Ética de la diferencia. En el campo de la antropología social. España, Ed. Universidad de Deusto.

- FARRO, Máximo. 2009. La formación del Museo de La Plata. Coleccionistas, comerciantes, estudiosos y naturalistas a fines del siglo XIX. Rosario, Ediciones Prehistoria, colección Historia de la Ciencia.

- FERNANDEZ, Luis A. 1993. Museología. Introducción a la teoría y práctica del museo. España, Ediciones Istmo.

- FERNANDEZ, Luis A. 2003. Introducción a la nueva museología. Buenos Aires, Alianza Editorial.

- FORNI, Floreal H.; GALLART, M. A. y VASILACHIS de GIALDINO. Métodos II. 1992. La práctica de la investigación. Buenos Aires. Centro Editor de América Latina.

- FOUCAULT, Michel. 1996. Las palabras y las cosas. España, Siglo XXI. (primera edición, 1968).

- FOUCAULT, Michel. 2005. La arqueología del saber. Siglo XXI. Argentina.

- FOUCAULT, Michel. 2008. El orden del discurso. Buenos Aires, Tusquets. (primera edición 1973). 
- GAELLE, Crenn. 2003. Rhétorique de la transparente et légitimité muséale: à propos de trois expositions d'ethnologie. En: Rev. Persee. Revieu Scientifique, Vol.52, № 52 , pp. 93-103, Paris, Ministère de la Jeunesse, de l'Éducation Nationale et de la Recherche.

- GALINIER, Jakques et Antoinette Molinié. 1998. Le crépuscule des lieux: mort et renaissance du musée d'ethnographie. Gradhiva, Revieu d'Histoire et d archives de l'anthropologie, $N^{\circ} 24$, pp. 93-102, Centre National du Livre, Paris.

- GARCIA, S. 2004. El Museo de La Plata y la divulgación científica en el marco de la extensión universitaria (1906-1930). Tesis doctoral. Facultad de Ciencias Naturales y Museo de la Universidad Nacional de La Plata.

- GARCIA CANCLINI, N. 1991. El consumo cultural en México. México, GrijalboCNCA.

- GARCIA CANCLINI, N. 1991. ¿Construcción o simulacro del objeto de estudio? Trabajo de campo y retórica textual. En: Alteridades, Revista de Ciencias Sociales de la Universidad de México, 1 (1): pp. 58-64.

- GARCIA CANCLINI, N. 1992. Culturas Híbridas. Estrategias para entrar y salir de la modernidad. Buenos Aires. Editorial Sudamericana.

- GARCÍA CANCLINI, N. 1996. Consumidores y ciudadanos. Conflictos multiculturales de la globalización. México, Ed. Grijalbo.

- GARDIN, J.C. 1968. Análisis documental y análisis estructural en arqueología. En: Estructuralismo y dialéctica. Bs. As. Paidós, pp.121-128.

- GARDIN, J. C. 1975. Essais d'analysais du discours arqueologique. Notes et monographies techniques, 7 .

- GALINDO CASTRO, Luis A. 2004. Museos, saberes y diversidad cultural en Venezuela. En: Museum Internacional, No 227 , pp. 54-65.

- GALINIER, Jakques et Antoinette Molinié. 1998. Le crépuscule des lieux: mort et renaissance du musée d'ethnographie, En: Gradhiva, Revieu d'Histoire et d archives de l'anthropologie, $\mathrm{N}^{\mathrm{o}} 24$, pp. 93-102, Centre National du Livre, Paris.

- GARRETON, Manuel A. 1999. Transformaciones sociales y reconstrucción de los estados nacionales: hacia una nueva matriz socio-política. En: La dinámica local/global. Cultura y Comunicación: Nuevos Desafíos. Ed. Ciccus, pp. 135-144.

- GARRETON, Manuel A. (compilador). 2003. El Espacio Cultural Latinoamericano. Bases para una política cultural de integración. Argentina, Fondo de Cultura Económica, Argentina. 
- GEERTZ, Clifford. 1978. La interpretación de las culturas. Barcelona. Gedisa.

- GEERTZ, Clifford. 1989. El antropólogo como autor. Barcelona, Paidós.

- GEERTZ, Clifford. 1991. Géneros confusos. La refiguración del pensamiento social. En El Surgimiento de la Antropología Posmoderna. México, Gedisa.

- GEERTZ, Clifford. 1994. Conocimiento local. Barcelona, Paidós.

- GOMEZ ALONSO, Rafael. 2003. El Museo: Espacio Creativo. En: Rev. Dialnet, N², Universidad Complutense de Madrid.

- GORE, Ernesto. El museo como organización. 1999. En: Lo Público y lo Privado en la Gestión de Museos. Alternativas institucionales para la gestión de museos. Buenos Aires, Fondo Nacional de las Artes/ Fundación Antorchas/ Fondo de Cultura Económica, pp. 41-69.

- GOROSITO KRAMER, Ana María. 1997. Identidad, cultura y nacionalidad. En: Globalización e identidad cultural. Ediciones Ciccus, pp. 101-111 Anthropos.

- GOTMAN, Anne. 1990. Le présent de l'héritage. En: Patrimoine en Folie. Ministère de la Culture et de la Communication. Collection Ethnologie de la France., Edition de la Maison des sciences de l'homme. Paris, Cahier 5, pp. 109-125.

- GREENBERG, Reesa. 2002. Jews, Museum, and Nacional Identities. En Ethnologies Musée, Vol. 24, № 2, Association Canadiens d'Ethnologie et de Folklore.

- GOETZ, J. P. y Le Compte, M. D. 1988. Etnografía y diseño cualitativo en investigación educativa. Madrid, Ed. Morata.

- GUIDDENS, Anthony. 1996. Cambio social en el mundo moderno. Alianza Universidad.

- GUIDDENS, Anthony. 2003. Un mundo desbocado. Los efectos de la globalización en nuestras vidas. Bs. As. Ed. Taurus.

- GUTIERREZ, A. 1997. Pierre Bourdieu. Las prácticas sociales. Universidad Nacional de Misiones, Editorial Universitaria, Colección Cátedra.

- HALL, Stuart- 1997. Representation: Cultural Representations and Signifying Practices. London, Sages Publication LTD.

- HAMMERSLEY M. y P. Atkinson. 1994. Etnografía. Métodos de Investigación. Buenos Aires, Paidós.

- HANDLER, Richard. 1993. An Anthropological Definition of the Museum and Its Purpose, Museum Anthropology, 17-1, pp. 33-36.

- HARTOG, François. 2004. Tiempo y Patrimonio. Museum Internacional, No 227. UNESCO. 
- HEIN, George. 1991. Teoría del aprendizaje constructivista. En: El Museo y las necesidades de la gente. Traducción al español de la Conferencia anual ICOM. CECA, Jerusalén, Buenos Aires, ICOM CA, pp.138 -144.

- HEIN, G. 1998. Learning in the Museum. New York: Routledge.

- HEIN, George E. 1999. The constructivist museum. En: The Educational Role of the Museum. London, Ed. Routedge.

- HERNANDEZ HERNANDEZ, F. 1992. Evolución del concepto museo. En: Revista general de Información y Documentación. Madrid, Universidad Complutense de Madrid, Vol. 2 (1), pp. 85-97.

- HOPENHAYN, Martín. 2002. Educación y cultura en Iberoamérica: situación, cruces y perspectivas. En: Iberoamérica, Diagnóstico y propuestas para el desarrollo cultural. N. García Canclini coordinador. Buenos Aires. Santillan, pp.297-337.

- HOOPER-GREENHILL, E. 1998. Los museos y sus visitantes. España, Ediciones Trea.

- JACKNIS, Ira. Franz Boas and Exhibits: On the limitations of the Museum Method of Antrhropology. 1985. En: Objects and Others. Essays on Museums and Material Culture. The University of Wisconsin Press, USA, History of Anthropology, Vol. 3, pp. $75-111$.

- JAMIN, Jean. 1998. Faut-il bruler le musée d'ethnographie? En: Gradhiva, Revieu d' Histoire et $d$ archives de 1'anthropologie, $\mathrm{N}^{0}$ 24: pp. 65-69, Centre National du Livre, Paris.

- JEUDY, Henri P. Gestion des Patrimoines. 1990. En: Patrimoine en Folie. Ministère de la Culture et de la Communication. Collection Ethnologie de la France, Edition de la Maison des Sciences de l'homme. Paris, Cahier 5, pp. 1-12.

- JUEZ, Fernando M. 2002. Contribuciones para una antropología del diseño. España, Gedisa.

- KAINE, Élisabeth. Les objets sont des lieux de savoir. 2002. En: Ethnologies Musées, Vol. 24, N² 2, Association Canadienne d'Ethnologie et de Folklore.

- KARP, I. Culture and Representation. En: Exhibiting Cultures. The poetic and politics of museum display. Washington, Smithsonian Institution Press. 1991; pp. 11-24.

- KIRSHENBLATT-GIMBLETT, Bárbara. 1991. Objects of Ethnography. En: Exhibiting Cultures. The poetics and politics of museum display. Washington, Smithsonian Institution Press, pp. 386-443. 
- KIRSHENBLATT-GIMBLETT, Bárbara. 1998. Destination Culture: Tourism, Museums and Heritage. Berkeley and Los Angeles, University of California Press.

- KRECH III, Shepard. Museums, voices, representations. 1994. En: Museum Anthropology. October 1996; Vol.18, № 3, pp. 3-9, Journal of the Cuncil for Museum Anthropology.

- LAHITTE H., Hurrell J. y Malpartida A. Relaciones 2. Crítica y expansión de la ecología de las ideas. 1989. Argentina, Ediciones Nuevo Siglo.

- LAHITTE, H. 1992. Sistemas cognitivos y representación en piezas etnográficas. La Plata, Universidad Nacional de la Plata, Cuadernos LARDA, 12 (3).

- LAHITTE, H. 1992. La matriz relacional de los procesos cognitivos. Salamanca, España, Editorial Amarú.

- LAHITTE, H. 1995. Ecología de la Educación. Departamento de Historia de la Educación. Serie Antropológica N ${ }^{0}$ 7, España, Universidad de Salamanca.

- LAHITTE, H. 1996. Epistemología y cognición. España, Universidad de Salamanca.

- LAHITTE, H. y J. Hurrell. 1999. Sobre la Integración de las Ciencias Naturales y Humanas. Buenos Aires, Editorial L.O.L.A.

- LAHITTE, H. y V. Ortiz Oria. 2005. El Otro. Antropología del sujeto. Buenos Aires, Editorial Nobuko.

- LARROSA, Jorge. 2004. Saber y Educación. En: Educación y filosofía. Enfoques. Barcelona, Eudeba.

- LATOUR, B. 1991. Nous n'avons jamais été modernes: essai d'anthropologie symétrique, Paris, La Découverte.

- LATOUR, B. (Director) 2007. Le Dialogue Des Cultures. Actes des rencontres inaugurales Du Musée Du Quay Branly (21 juin 2006). Paris, Babel.

- LAVINE, Steven D. e Ivan Karp. 1991. Introduction; Museums and Multiculturalism En: Exhibiting Cultures. The poetic and politics of museum display. Washington, Smithsonian Institution Press, pp. 1-9.

- LÉVI-STRAUSS, Claude. 1968. Antropología Estructural. Buenos Aires, Eudeba.

- LÉVI-STRAUSS, C. 1986. Antropología estructural II. México, Siglo XXI.

- LÉVI-STRAUSS, C. 1994. El pensamiento salvaje. México, Fondo de Cultura Económica.

- LOPEZ, M. y Murriello S. 2005. Ciencias e educação em museus no final do século XIX. En: Museus e Ciencias, Vol. 12, pp. 13-30, Río de Janeiro, História, Ciencias, Saúde. Dossie $4^{\circ}$ Congreso Mundial de Museus e Centros de Ciencia. 
- LYOTARD, Jean F. 1992. La Posmodernidad (explicada para niños). España, Gedisa.

- MAGARIÑOS DE MORENTIN, J. A. 2003. Semiótica Indicial. Acerca de la interpretación de los objetos y los comportamientos. España, Coruña, Edicios do Castro. - MAGARIÑOS DE MORENTIN, Juan Ángel. 1996. Comentarios a Fundamentos Lógicos de la Semiótica. En: Los Fundamentos lógicos de la semiótica y su práctica. Buenos Aires, Edicial, pp. 61-164.

- MAGARIÑOS DE MORENTIN, Juan Ángel. 2008. La semiótica de los bordes. Apuntes de metodología semiótica. Córdoba. Comunic-Arte. Colección lengua y discurso.

- MARCUS, G. y K. E. Cushman. 1991. La etnografía como textos. En: El surgimiento de la antropología posmoderna. México, Gedisa.

- MARCUS, G. y Fischer, M. 2000. La Antropología como Crítica Cultural. Un momento experimental en las ciencias humanas. Buenos Aires, Amorrortu.

- MARTIN BARBERO, J. Heredando el futuro. 1996. Pensar la educación desde la comunicación. En: Nómadas, Universidad Central de Colombia, Bogotá, dic. 1996, pp.10-22.

- MARTIN BARBERO, J. 1998. Usos sociales de los medios. En: Los estudios de recepción en América Latina, Florencia Saintout, Buenos Aires, Ediciones de Periodismo y Comunicación.

- MATIHEU, J. L'Objet et ses contextes. 1987. Bulletin d'histoire de la culture matérielle. Canadá, № 26, pp. 7-18.

- MigUELEZ, M. 1995. El Paradigma Emergente. Barcelona, Gedisa.

- MORENO, Francisco P. 1890. El Museo de La Plata. Rápida Ojeada sobre su Fundación y Desarrollo. En: Revista del Museo de la Plata, Tom 1, Imprenta y Talleres del Museo de La Plata.

- MORIN, E. 2007. Articular los saberes. Buenos Aires, Paidós.

- MORITZ SCHWARCZ, Lilia. 1993. O Espectáculo das Racas. Cientistas, Instituicoes e Questiao Racial no Brasil. 1870-1930. Sao Paulo, Companhia Das Letras.

- MOUVÉ, Marie. 1999. Un patrimoine, deux musées: la restituions de la Potlatch Collection. Ethnologie française, 2 , pp. 419-430.

- MURPHY, Berenice. 2004. Memoria, Hhistoria y Museos. En: Rev. Museum Internacional. Diversidad cultural y patrimonio. Septiembre, No 227: pp. 66-74. 
- MURRIELO, Sandra E. 2006. As exposições e seus publicos: a paleontologia no museode la plata (província de buenos aires, argentina). Universidade estadual de campinas. Instituto de geociencias. http://libdigi.unicamp.br

- NASON, James D. 1999. "Our" Indians: The Unidimensional Indian in the Disembodied Local Past. En: The Changing Presentation of the American Indian. Museums and Native Cultures. National Museum of the American Indian Smithsonian Institution. University of Washington Press, Washington, pp. 29- 46.

- NOVAK, J. y D. Bob Gowin. 1988. Aprendiendo a aprender. Barcelona, Ediciones Martínez Roca.

- ORTIZ, Renato. 2004. Taquigrafiando lo social. Argentina, Siglo XXI.

- PAZOS, Álvaro. 1998. La re-presentación de la cultura. Museos Etnográficos y Antropología. En: Política y Sociedad, 27: pp. 33-45, Madrid, Universidad Autónoma de Madrid.

- PEDONE, Claudia. 2000. El trabajo de campo y los métodos cualitativos. Necesidad de nuevas reflexiones desde las geografías latinoamericanas. En: Scripta Nova. Revista Electrónica de Geografía y Ciencias Sociales, Universidad de Barcelona, febrero de $2000 ; \mathrm{N}^{0} 57$.

- PEERS, Laura. 2000. Native Americans in Museums. Anthropology Today, 16-6: pp. $8-13$.

- PEIRCE, Charles S. La Ciencia de la Semiótica. Buenos Aires, Nueva Visión. 1986.

- PEREZ GOLlÁN, José A. 1995. Mr. Ward en Buenos Aires: los Museos y el Proyecto de Nación a Fines del Siglo XIX. Revista Ciencia Hoy, Vol. 5, No 28.

- PEREZ SANTOS, M. Eloisa. 2000. Estudio de visitantes en museos: metodología y aplicaciones. España, Ed. Trea.

- PEREZ SANTOS, María Eloisa. 2008. El estado de la cuestión de los estudios de público en España. MUS-A; No10 (El público y el Museo), pp. 20-30.

- PICCINI, Mabel. 1996. La sociedad de los espectadores. Notas sobre algunas teorías de la recepción. Seminario internacional sobre estudios de visitantes de museo y evaluación de exposiciones. Museo José Hernández (GCBA). 1998. También En: Rev. Cuicuilco, Serie Nueva museología mexicana, Vol. 3, No 7 .

- PODGORNY, I. 2000. El Argentino despertar de la Faunas y de las Gentes Prehistóricas. Buenos Aires, Programa de Historia Oral y Gráfica de la UBA, Secretaría de Extensión Universitaria y Bienestar Estudiantil, Universidad de Buenos Aires. 
- PODGORNY, I. 2005. La mirada que pasa: museos, educación pública y visualización de la evidencia científica. En: Museus e Ciencias, Vol. 12, pp. 231- 264, Río de Janeiro, História, Ciencias, Saúde. Dossie $4^{\circ}$ Congresso mundial de Museus e Centros de Ciencia.

- PODGORNY, I. 2008. El Desierto en una Vitrina. Museos e Historia Natural en la Argentina, 1810-1890. Argentina, Ed. LIMUSA.

- POMIAN, Krzysztof. 1987. Collectioneurs, amateurs et curieux, Paris, Bibliothèque des Histoires, Editions Gallimard.

- POMIAN, Krzysztof. 1990. Musée et patrimoine. En: Patrimoine en Folie. Ministère de la Culture et de la Communication. Collection Ethnologie de la France. Edition de la Maison des sciences de 1'homme. Paris, Cahier 5: pp. 177-198.

- POULOT, Dominique. 2002. Musées et expositions des origines à nos jours. Sciences humaines, hors-série 37: pp. 52-5.

- PRATS, Llorenc. 1997. Antropología y Patrimonio. Barcelona, Ed. Ariel.

- PRATS, Llorenc. 2005. Concepto y gestión del patrimonio local. En: Cuadernos de Antropología Social, Barcelona, Julio 2005; No 21.

- RABINOW, Paul. 1991. Las representaciones son hechos sociales. Modernidad y posmodernidad en la Antropología. En: Clifford James y George Marcus. Retóricas de la Antropología. Barcelona, Júcar, pp. 270-321.

- RICCARDI, A. 1989. Las Ideas y la Obra de Francisco Pascasio Moreno. La Plata, Fundación Museo de La Pata "Francisco P. Moreno".

- SANCHEZ-MORA, C. y J. Tagueña. 2003. Exhibir y diseñar ¿para quién? La visión del público en los museos de ciencias. En: Rev. Elementos, № 52.

- SCHMILMUK, Graciela. 1991. El museo como piel de cebolla. En: ARTEunesp, San Pablo.; Vol.7.

- SCHMILMUK, Graciela. 1996. Venturas y desventuras de los estudios de público. En: Rev. Cuicuilco, Serie Nueva museología mexicana, Vol. 3, No 7 .

Pablo.; Vol.7.

- SCREVEN, C.G. 1990. Uses of Evaluation Before, During, and After Exhibit Design. ILVS Review: A Journal of Visitor Behavior. Vol 1(2) pp. 33-66.

Pablo.; Vol.7.

- SCREVEN, C.G. 1993. Museums and Informal Education. CCMS Bulletin 1 (1). Consultable en "http://www.infed.org/archives/e-texts/screven-museums.htm.

- SEBEOK, Thomas A. 1996. Signos: Una introducción a la semiótica. Barcelona, 
Paidós.

- SEÑOR, B. 2006. Foucault museo: la diferencia, la representación y la genealogía. En: Museo y Sociedad.; (4)1, pp. 1-14. www.le.ac.uk/ms/museumsociety.html

- STAVENHAGEN, Rodolfo. 2002. Cultos, incultos y ocultos: las nuevas identidades latinoamericanas. En: Iberoamérica. Diagnóstico y propuestas para el desarrollo cultural. N. García Canclini coordinador. Buenos Aires. Santillana. pp. 31- 52.

- STOKING, G. 1985. Essays on museums and material culture. En: Objects and Others. Essays on Museums and Material Culture. The University of Wisconsin Press, USA, History of Anthropology, Vol. 3: pp.3-14.

- STOCKLER COELHO de SOUZA, M. 2007. A dádiva indígena e a dívida antropológica: o patrimônio cultural entre deteitos universais e relações particulares. Serie Antropológica, Universidad de Brasilia, Brasilia, Vol. 415: pp. 6-18.

- STURTEVANT, W.C. 1969. Does Anthropology needs museum? Proceedings of the Biological Society of Washington, 182: pp. 619-650

- STURTEVANT, W.C. 1973. Museums as anthropological data banks. Anthropology Beyond the university (A. Redfield, ed). Press. SO. Anthropological Society, 7: pp. 40 55.

- SILVERMAN, Helaine. 2005. Reinventing the Museum: Historical and Contemporary Perspectives on the Parad. American Anthropologist. Dec 2005; 107, 4; Platinum Periodicals: pp. 715.

- TELLEZ GIRÓN LÒPEZ, R. 2002. Antropología, Identidades y Globalización. En: Rev. Elementos, México, Universidad Autónoma de Puebla, № 44: pp. 19-23.

- TERREL, John. 1991. Disneyland and the Future of Museum Anthropology, American Anthropologist, 93: pp. 149-153.

- TERUGGI, Mario E. 1994. Museo de La Plata 1888-1988. Una centuria de honra. La Plata, Fundación Museo de La Plata Francisco Pascasio Moreno. (Tercera edición).

- TODOROV, Tzvetan. 1991. Nosotros y los Otros. Reflexión sobre la Diversidad Humana. México, Siglo XXI.

- TORRES, Luis María. 1927. Guía para visitar el Museo de La Plata. La Plata, Universidad Nacional de La Plata. UNLP.

- TORRES, Patricia. 2001. Cómo lograr una experiencia significativa en el museo. Consideraciones para realizar un guión de visita guiada. En: Gaceta de Museos. Julio diciembre 2001; Número 23-24, México. 
- TRIGGER, B. G. 1985. Writing the History of Arqueology: A Survey of Trends. En: Objects and Others. The University of Wisconsin, USA, Vol. 3.

- TURGEON, Laurier. 2002. Musées d'ethnologie. Nouveaux défis, nouveaux terains. En: ethnologies, Vol. 24, No 2, Ed. Association Canadiens d'Ethnologie et de Folklore.

- TYLOR, R. y Bogan. 1992. Introducción a los métodos cualitativos de investigación. Buenos Aires. Paidós.

- VAN DIJK, Teun A. 1983. La Ciencia del Texto. Un enfoque interdisciplinario. Buenos Aires. Paidós.

- VAN DIJK, Teun. 1999. El análisis crítico del discurso. En: Anthropos, Barcelona. Sept-Oct., pp. 23-36.

- VALLES, Miguel S. 1999. Técnicas cualitativas de investigación social. España, Editorial Síntesis.

- VARGAS ARENAS, I. 2002. Los bienes culturales y la intangibilidad de lo corpóreo. En: Boletín Antropológico. Sept.- Dic. 2002; Año 20, Nº 56: pp. 789- 814, Universidad de Los Andes, Mérida.

- VATTIMO, G. 1990. La sociedad transparente. Buenos Aires. Paidós.

- VATTIMO, G. 1991. Ética de la Interpretación. Buenos Aires, Paidós.

- VERON, Eliseo y Martín Levasseur. 1990. Ethnographie de l'exposition: L'espace, le corp et le sens. Paris, Bibliothèque Publique d'information. Centre Georges Pompidou/Gracett.

- VOLKERT, James. 1997. Los Museos en los albores del siglo XXI En Rev. Ciencia Hoy, Vol. 7, No 39.

- WABENSBERG, J. 1998. Ideas sobre la complejidad del mundo. España. Tusquets.

- WAGENSBERG, J. 2005. O museu "total", una ferramenta para a mudanza social. En: Museus e Ciencias, Vol. 12: pp. 309-321. Río de Janeiro, História, Ciencias, Saúde. Dossie $4^{\circ}$ Congresso mundial de Museus e Centros de Ciencia.

- WARNIER, J. P. 1999. Construire la culture matérielle, Paris, PUF.

- WATZLAWICK, P. 1995. El sinsentido del sentido o el sentido del sinsentido. Barcelona, Editorial Herder.

- ZUNZUNEGUI, Santos. 2001. El laberinto de la mirada. El Museo como espacio del sentido. En: Cuadernos $N^{o}$ 17, Facultad de Humanidades y Ciencias Sociales, Universidad Nacional de Jujuy, pp. 521-540.

- ZUNZUNEGUI, Santos. 2003. Metamorfosis de la Mirada. Museo y Semiótica. Madrid, Ediciones Cátedra. 